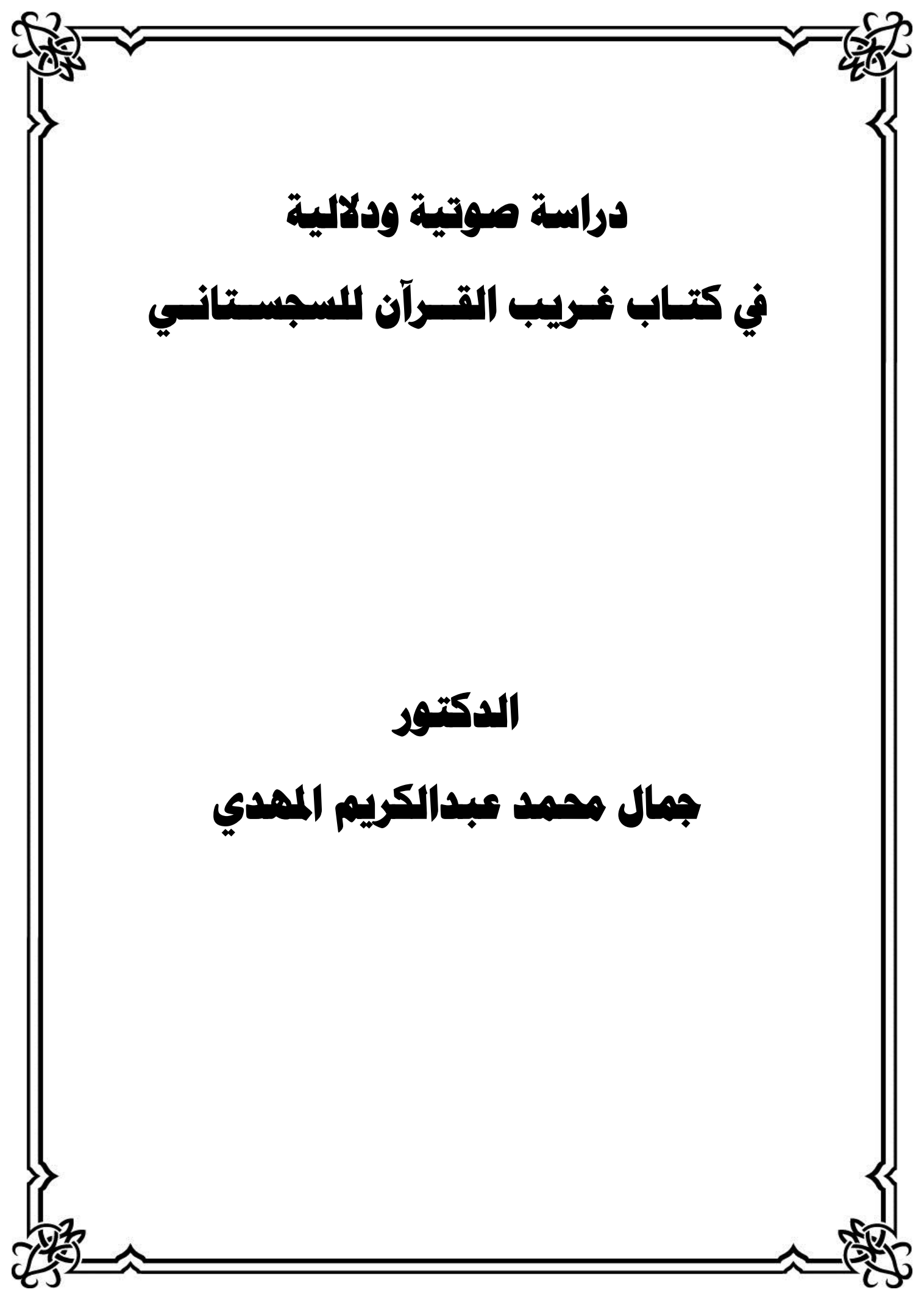


الحمد لله رب العالمين و الصـلاة و السـلام علي أفصــح مــن نطــق

بالضـاد سيدنا ومو لانا محمد صلي الله عليه و علي آله و آصحابه ومن ســار علي دربه إلى يوم الدين وبعد .

فان أهمية كتاب " غريب القرآن علي حروف المعجم " ثرجع إلى أمور منها :

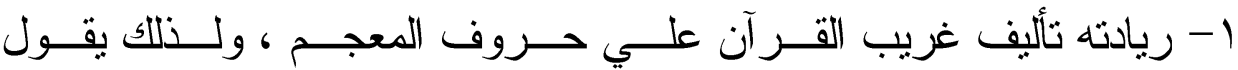
الدكتور/نصار موضحا ذلك " وصفوة القول في هذه الحركة : أنها الحركة العلمبة الأولي في الإسلام بدأت في عصر مبكر لا بعدو النصف الأول من القرن الأول للهجرة ، ودونت بعد هذا التاريخ بقليل، وسارت في طريقين : التزتيب وفقا للسور في المصحف ، وهو أقدمها ، و التزتيب الألف بــائي، و استمرا في الوجود في حياة الحركة كلها ، وكانت الألفاظ نزتب في داخل ولن هذه السور بحسب ورودها في الآيات أيضنا أما الترنيب الأف بائي فابتـــــأ معقدا عند العزيزي في القرن الرابع من جهة ومبسطا من جهة أخــري ، معقدا من حيث فصله بين المفتوح و المضدوم و المكسور ، ومبســــا مــن مئن

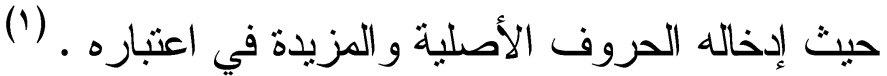
r- هنا بالإضافة إلى اهتماماته المبكرة بمباحث صوتية ودلالية مهمــة فمــن القضايا الصونية : الإبدال -الإدغام - المخالفة الصونية - تخفيف الههز وتحقيقه ... الخ ومن القضايا الدلالية الاشتقاق الكلي والجزئسـي وتعليـلـل

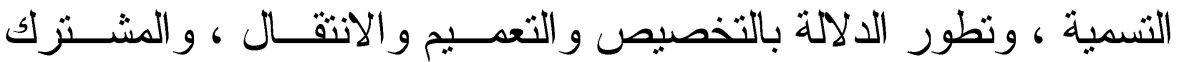

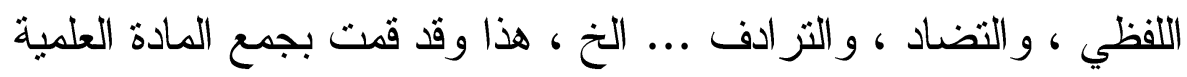
من خلال كتاب "غريب القرآن" للسجستاني ، التي تتدرج تحت كل مــن

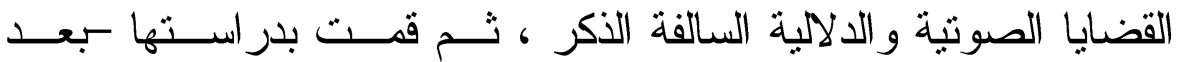


تصنيفها- دراسة وصفية ، هذا ، وقد اشتنل البحث علي مقدمة بينت فيها

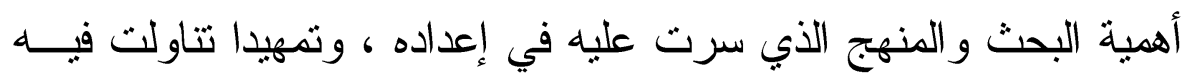

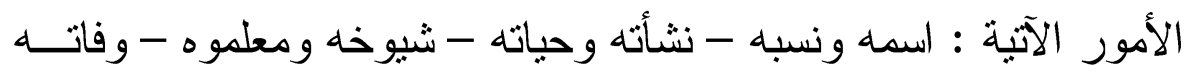

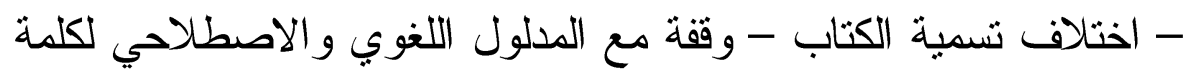
"غريب" - منهج المؤلف في عرض مادة هذا الكتاب.

البساب الأول : الدرس الصوني في غريب القرآن للسجستاني ويتكون مـن أربعة فصول : الفصل الأول : الإدغام - الفصل الثاني الإني : المخالفة الصوتية الإنية

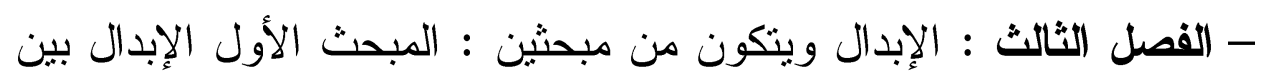
الصوامت بعضها من بعض المبحث الثاني الإبدال بين الصوائت القصيرة بعضها من بعض ـ الفصل الرابع : تخفيف الهمز وتحقيقه .

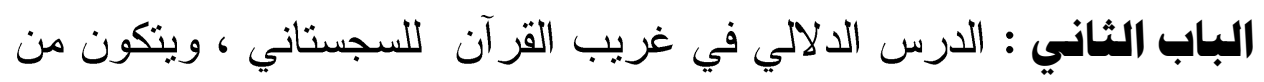

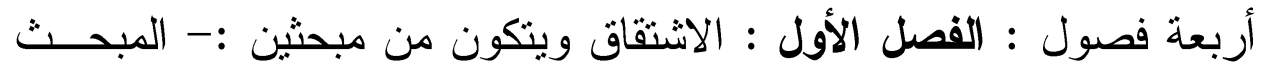

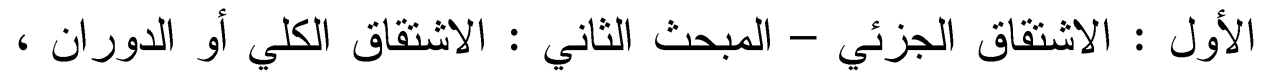

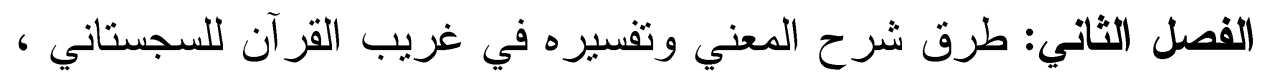

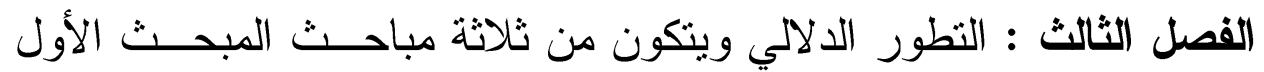

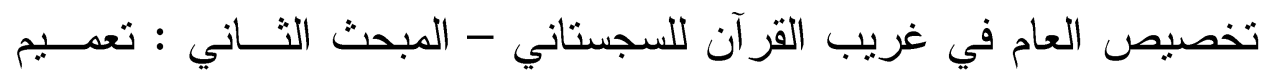

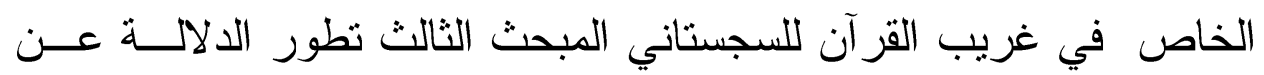
طريق الانتقال عند السجتاني ، الفصل الرابع : تعدد المعني للفظ ، وتعدد

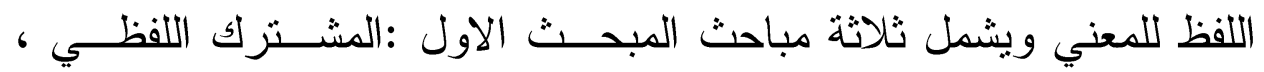

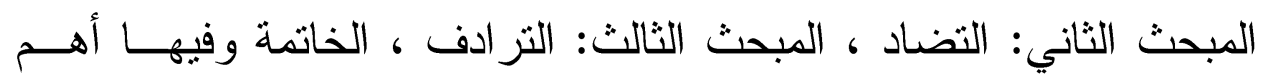

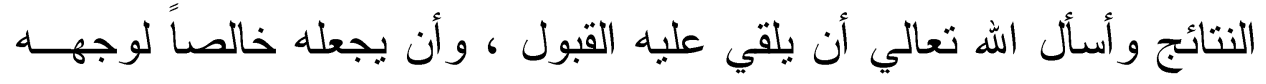

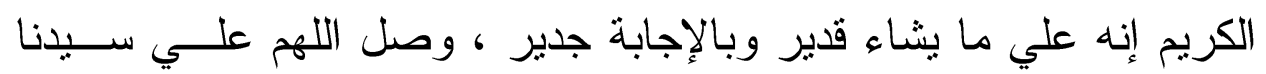
محمد النبي الأمي و علي آلة وصحبه وسلم.

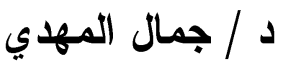




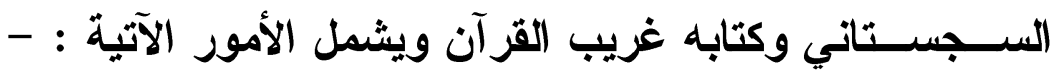

هو أبو بكر محمد بن عزيز بن أعين العزيزي السجستاني ، وقد

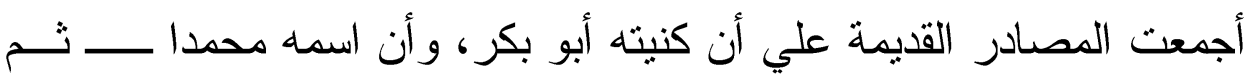
اختلفت في اسم أبيه اختلافا كبير ا ، هل هو عزيز أم عزبر ، وهل نســبته هي العزيزي أم العزيري ، وتوضــبـح ذلــك أن كتــاب غريــب القــر آن للسجستاني قد حظي بشهرة و اسعة طبقت الآفاق بين الخاصة و العامة معا ، وتقبله الناس جميعا قبو لا حسنا لذلك استتسخ فـي كثبـر مــن الأمصـــار و الأقطار ، ولما كان مؤلفه يعرف باسم أبيه - علي عادة المــؤرخين فـي التعريف بمن كانت أسماؤهم مشهورة منل : محمد ، و عبداله ، و أنه أيضا لم يعرف لله سوي هذا الكتاب - فقد وفع تصحيف في بعض هذه النسخ في اسم أبيه ، ونسبته ، وقام خلاف طويل عريض حتى ألف فيه بعض العلماء

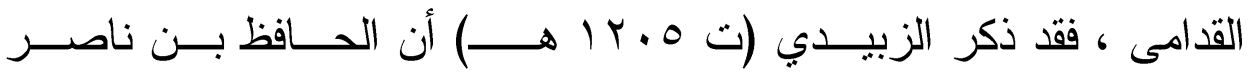
(ت .00هـ) صنف في هذا الخلاف رسالة مستقلة ، وجمع كلام الناس (1) : بيد أن جمهور العلماء أقر علي أنه ابن عزيز بزاءاين ، و أنه العزيزي نسبه إلي أبيه عزيز ، كما أن أقدم المصادر التي عرفت به ذكرته بز اعين(؟).

تاج العروس ( عز ز ) طبعة الكويت 10 / ب r تحقيـق الغربــاوي وآخـرين

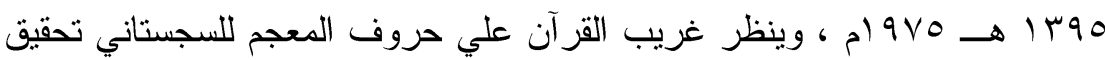

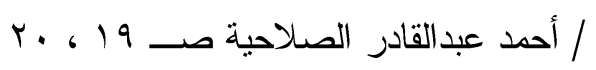
ينظر السابق بعينه. 
وممن قالو ا إنه محمد بن عزيـز ابــن النــديم فــي الفهرســـ

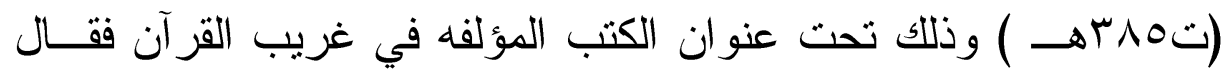
كتاب غريب القرآن لمحمد بن عزيز السجستاني" (1) كما ذكـره عرضـــا محمد بن أبي بكر المديني الأصفهاني في مقدمة كتابه " المجموع المغيــث في غريبي القرآن و الحديث"(r) كما ذكره الفيروز ابادي في القاموس المحيط الإيط ونص علي أن اسم أبيه بالز اي ، ومن ذكر غير ذلك فقد صــحف فقـال " ومحمد بن عزيز السجستاني مؤلف غريب القرآن ، و البغاددة يقولون بالر اء و هو تصحيف ، وبعضهم صنف فيه ، وجميع كلام الناس ، وقد ضرب في

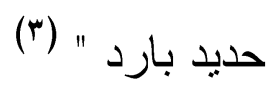

كما أكد الزبيدي كلام الفيروز ابادي وعضـــده بالثـــو اهد فقــال: "و أبوبكر محمد بن عزيز كزبير ، وقد أغفل ضبطه قصور ا فإنه لا بعتمـــ هنا علي الشهرة مع وجود الاختلاف ، العزيـزي السجسـناني المفسـر : مؤلف غريب القرآن ، و المتوفي سنة ، بسهــ ، و البخاددة أبي البغداديون يقولون هو محمد بن عزير بالر اء ، ومنهم الخافظ أبو الفضل محمـــــــن ابـن ناصر السلامي ، و الحافظ أبو بكر محمد بن عبدالغني بن نقطة وابن النجار صاحب التاريخ ، و أبو محمد بن عبيد الله، وعبدالله بن الصباح فؤلاء كلهم

$$
\text { الفهرست لابن النديم صـ or دار المعرفة / بيروت - لبنان }
$$

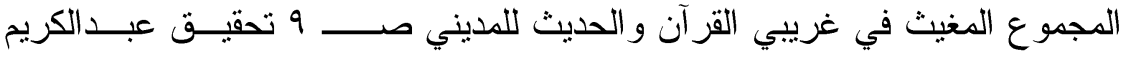

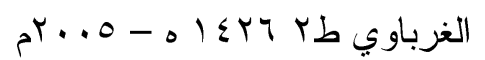

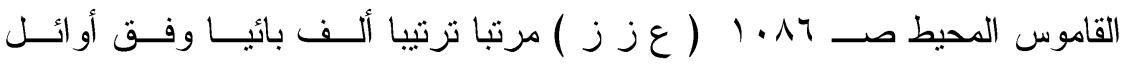
الحروف. لمجد الدين محمد بن يعقوب الفيروز ابادي ، مراجعة أنس محمد الثامي

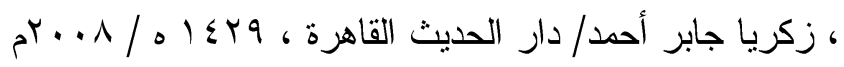


ضبطو ابلر اء ، وتبعهم من المغاربة الحافظ أبو علي الصدفي، وأبو بكـر بن العربي وأبو عامر العبدري ، و القاسم التجيبي في آخرين ، و إليه ذهب وله

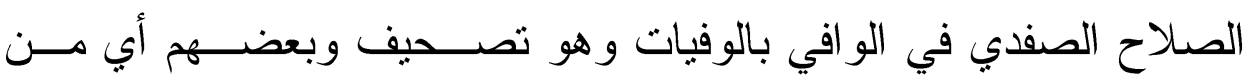
البخاددة ، و المر اد به الحافظ بن ناصر قد صنف فيه رسالة مستقلة ، وجمع لئل

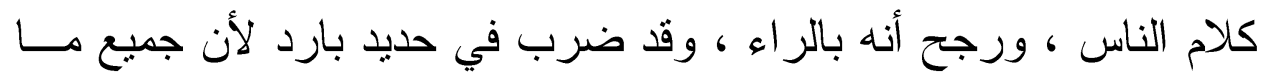
احتج به فيها راجع إلى الكتابة لا إلى الضبط من قبل الحروف بل هو مسن قبل الناظرين في تللك الكتابات وليس في مجموعه ما يفيد العلم بأن آخــره

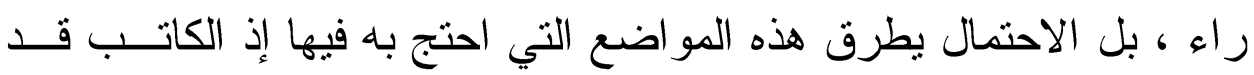
يذهل عن نقط الزاب فتصير راء، ثم ما المانع أن يكون فوقها نقطة فجعلها

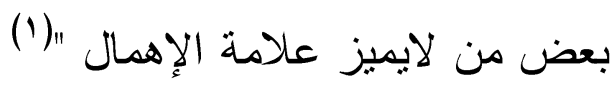
و علي كل حال فإنه إذا كان لــي مــن رأي أو تــرجيح فـإنني

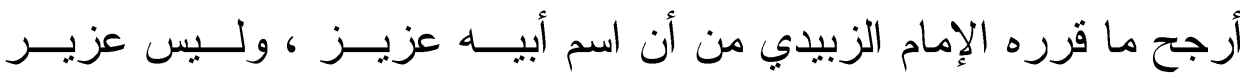

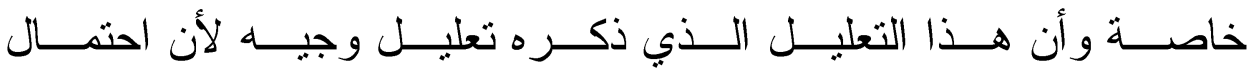

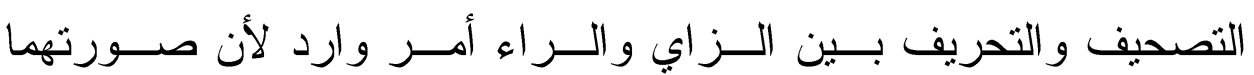

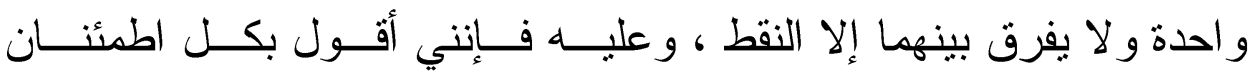

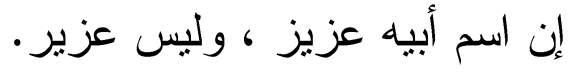


لم تذكر الدصادر الني بين أيدينا شيئا عن نشأته ، و لا عن تفاصيل

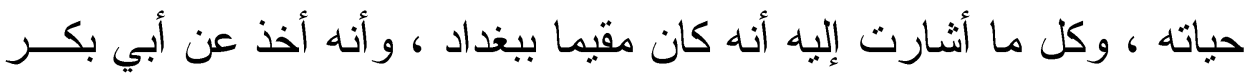

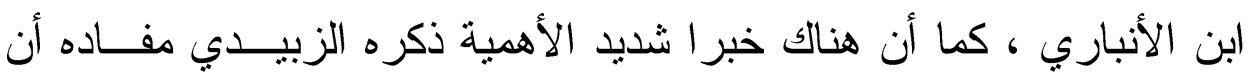

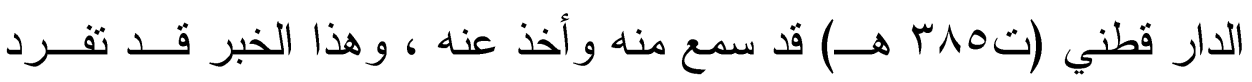

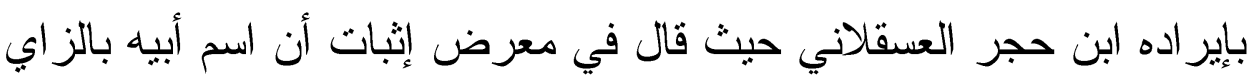

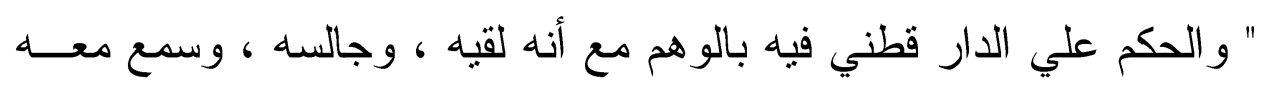

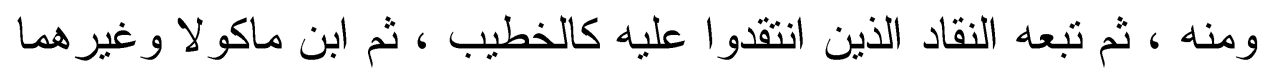

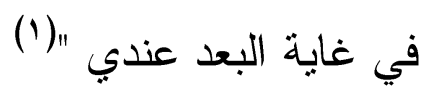

هذا بالإضافة إلى أن المصادر و الوثائق التاريخية تكاد تجمع علـي

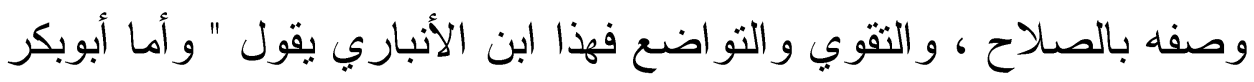

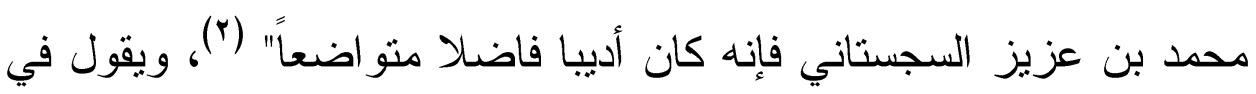

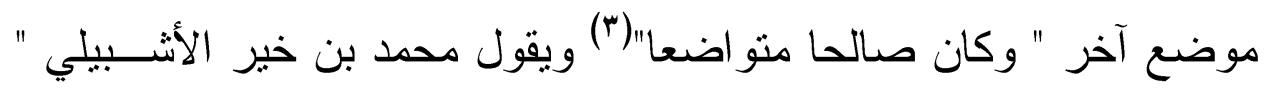

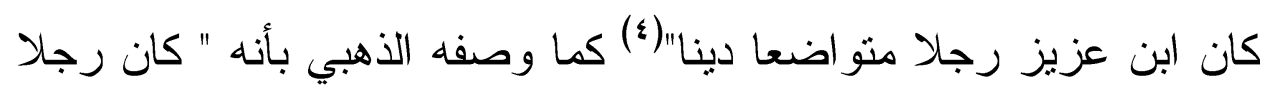

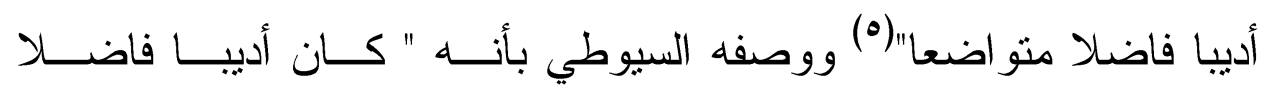

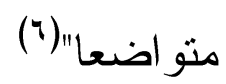

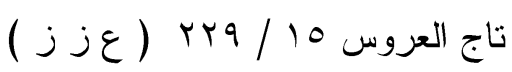

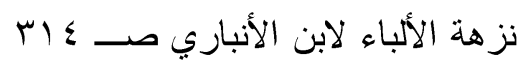

$$
\begin{aligned}
& \text { السابق بعينه }
\end{aligned}
$$

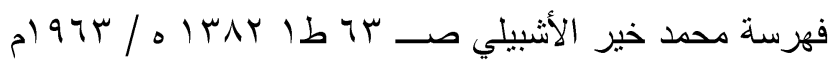

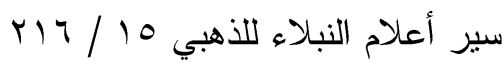

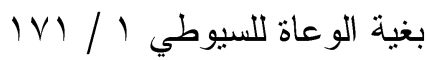


شيوخه ومعلموه : ت شيوه

أما فيما يتعلق بشيوخه ومعمليـــه فيبــدو أن المر اجــع و الوثــائق

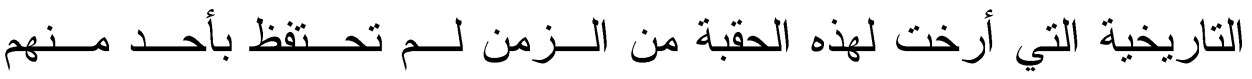
سوي أبي بكر بن الأنباري الذي يقول عنــهـ ابـن خلكــان " أبــو بكــر محمد بن أبي محمد القاسم بن محمد بن بشــار بــن الحســن بــن بيــان

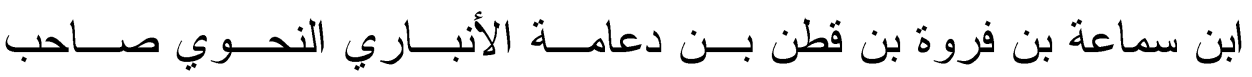
التصانيف في النحــو و الأدب كــان علامـــة وقتــهـ فـي الآداب و أكثــر

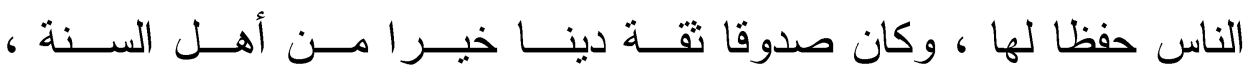
وصنف كتبا كثيرة في علــوم القــر آن وغريــب الحــديث ، و المشـــل ، و الوقف ، و الابتداء ، و الرد علي من خــالف مصــــف العامــة وكتــاب

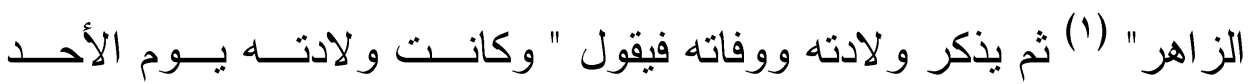
لإحدي عشرة ليلة خلت من رجــب ســنة إحــدي وســبعين ومــائتنين ، ونوفي ليلة عيـــ النحــر ســنة ثـــان وعثــرين ، وقيـلـ ســنة ســبع و عشرين ، وثلاثثائة "(r)

مؤلفاته :

و أما فيما بتعلق بمؤلفاته فيبدو كذلك أنه لم يكن له ســوي كتــاب " غريب القرآن علي حروف المعجم " ومما يؤكد ذلك قول محمد بن خيـر " ذكر أبو مروان الطبني عن ابن خالويه النحوي قال كان ابن عزيز رجــلا منو اضعا دينا من غلمان ابن الأنباري ، و عمل الكتاب في طول عمـره ، 
ورأيته يصححه عليه ويجبره بالثيء فيزيده فيه ، و ادعاه قوم ، وكـذذبوا ، ومات صانعه ولم يسمع منه فقر أته علي أبي عمر تصحيحا ... إلى أن قال قال الحسين بن خالويه : كان أبو بكر بن عزيز معنا عند أبي بكـر ابــن الأنباري فلما ألف كتابه في غريب القرآن ابتدأ بقر اعته علي سبيل التصحيح

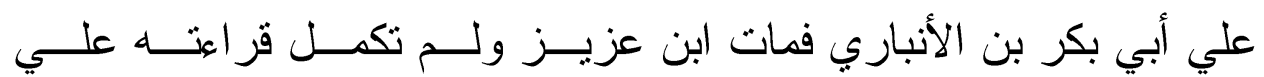
أبي بكر"(1) كما يقول السيوطي " أقام في تأليفه خمس عشرة سنة يحــرره هو وشيخه أبو بكر بن الأنباري"(r) كما يقول الزركلي في معرض التعريف به " محمد بن عزيز السجستاني أبو بكر العزيزي : مفسر، اشتهر بكتابــه غريب القر آن علي حروف المعجم ، صنفه في خمس عشرة سنة ، وكــان

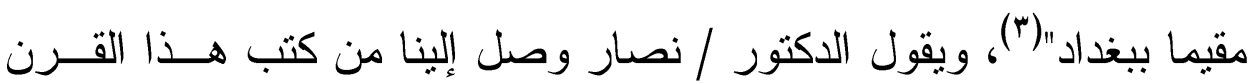
كتاب ابن عزيز الذي روي أبــو البركــات الأنبــاري أنـــه صــنفه فــي خمس عشرة سنة ، وكان بقرؤه علي شيخه أبي بكر بن الأنبــاري فكــان

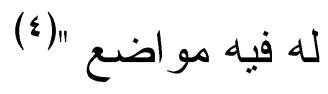

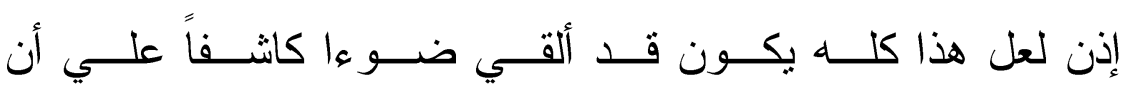

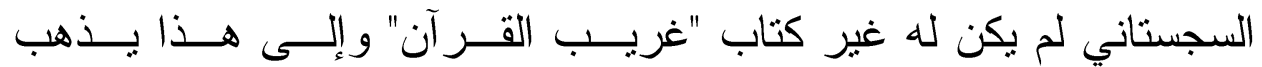

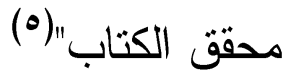

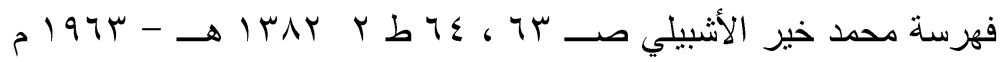

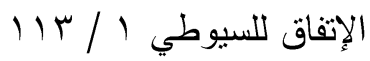

$$
\begin{aligned}
& \text { الأعلام 0/ / / الافي }
\end{aligned}
$$

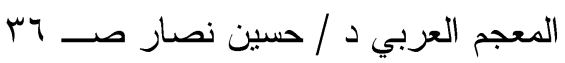

ينظر غريب القرآن علي حروف المعجم تحقيق / أحمد عبدالقادر صلاحية صـ19 19 


\section{وف ونـاته :}

أما فيما بتعلق بالعام الذي توفي فيه فيبدو أنه تــوفي فـي حـدود

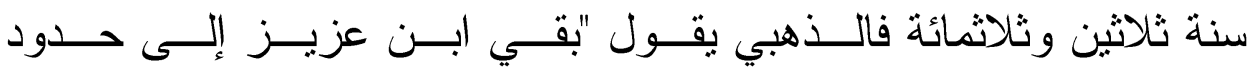

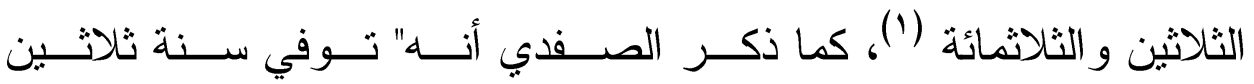

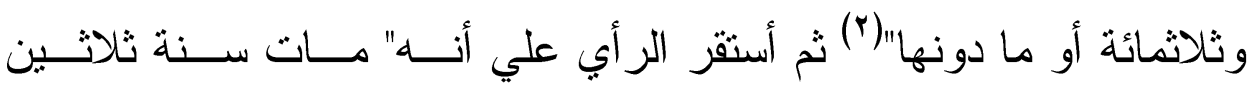

وثلاثمائة" (r)

\section{اختلاف تسمية الكتاب :}

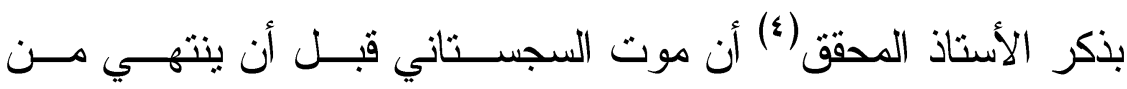

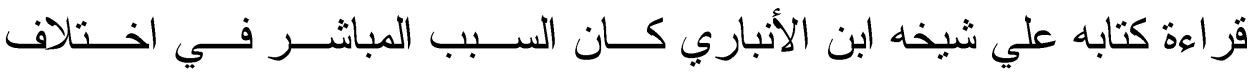

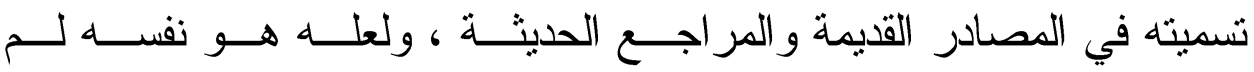
بطلق عليها اسما فسمى بموضو عه فليس فــي خطــب النســـخ المخطوطـــة

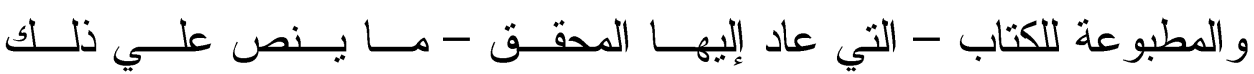
ولكنها تجمع علي أنه " تقسـير غريــب القـر آن المؤلــف علــي حـروف

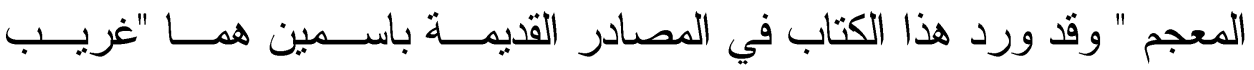

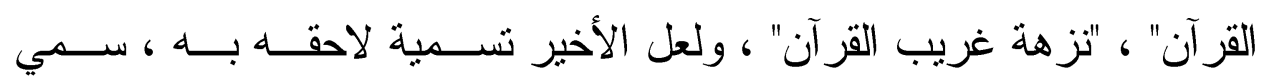

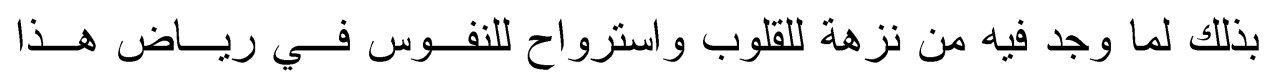

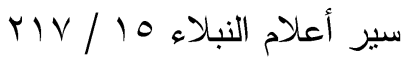

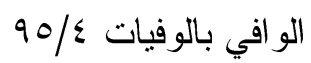

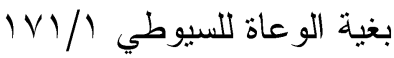

غريب القرأن علي حروف المعجم : دراسة وتحقيق احمــــــــــالقادر الصــلاحية 


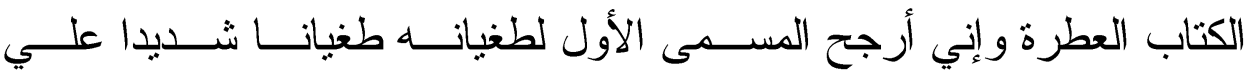

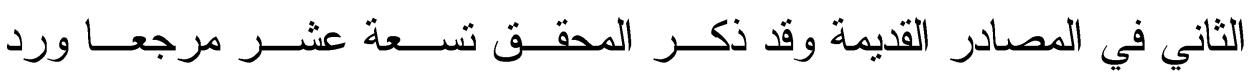
فيها اسم الكتاب بالمسي الأول فمن هذه المصادر ما يأتي : 1- كان ابن النديم من أو ائل الين ذكروا كتاب السجستاني باسم "غريب

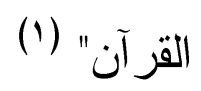

r- ذكره ابن سعبد الحافظ باسم غريب القرآن علي حروف المعجم(r) ب- ذكره الخطيب البغدادي في تلخــيص المتشـــابه "غريــب القــر آن المصنف علي حروف المعجم"(") ع- ذكره ابن ماكو لا "غريب القرآن علي حروف المعجم "(ء) ه- ذكره السمعاني " غريب القر آن " (ه) ؟- ذكره الفيروز ابادي "مؤلف غريب القر آن"(؟) V- ذكره ابن حجر العســلاني فـي غيـر موضــع " اشــنهر علـي

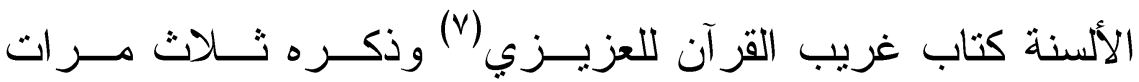
باسم غريب القرآن ، ومرة وحيدة باسم الألفاظ . (^)

$$
\text { الفهرست لابن النديم صــ }
$$

المؤتلف و المختلف لابن سعيد مخطوط ورقة ( ؟ 9) تلخيص المتشابه للخطيب البغدادي // ابتح

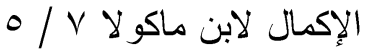

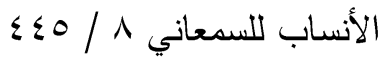

القاموس المحيط ( عزز )

ت

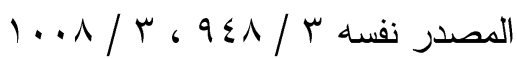


1- وذكره طاش كبري ز اده " غريب القر آن "(1) 9-كما ذكره الزبيدي غير مرة " غريب القرآن " ..... الخ وبعد أن ذكر الأستاذ المحقق ورود اسم هــــا الكتــاب فــي تشــعة عشــر

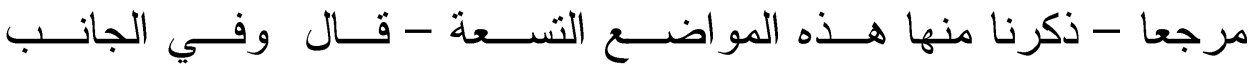
الآخر لم أجد سوي ثناثثة مؤلفين ذكروه باسم نزهة القلوب وهم : -

ا- ابن خير الأشبيلي " كتاب نزهة القلوب في تفسـير غريــب القــر آن علي حروف المعجم" وفي نهاية تعريفه به ذكر قــول ابــن خالويــهـ" فلما ألف كتابه في غريب القرآن"(r) وهـــ لا يــدل علـي أن اســـهـ

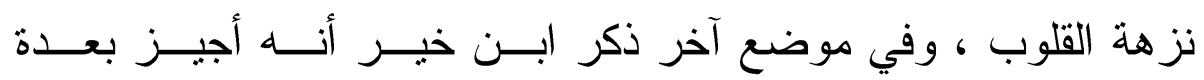

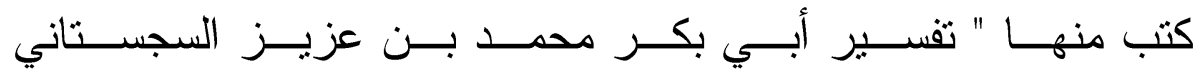

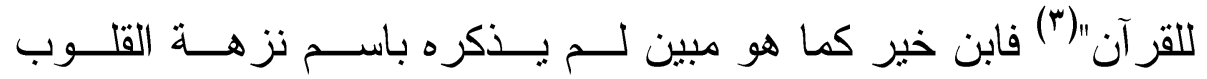

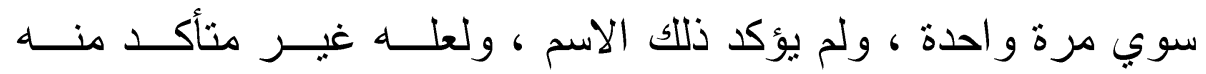
حتى ذكره في المقبوس الأخير علي تلاكك الحالـــة فضــلا عـن محبـــة

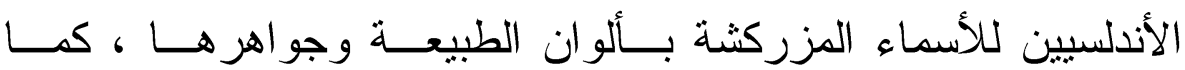

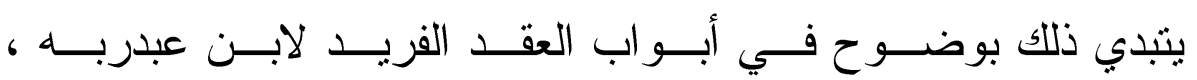
و المغرب في حلي المعرب لابن سعبد .

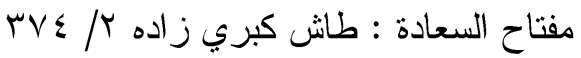

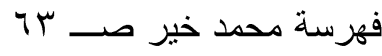

6 6 6 6- 6- 
ץ-حاجي خليفة وقد ذكره مرنين الأولي باسم "فــي غريــب القــر آن"(1)

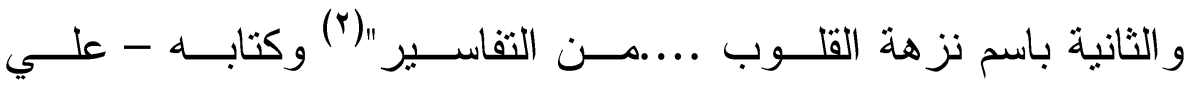
ماله من قدر - غير معتمد لما فيه من سهو وو هم •

r- فخر الدين الطريحي يقول عن كتاب السجستاني: "غريب القرآن المسمى بنزهة القلوب وفرحة المكروب"(ّ) ويلفت الاتتباه في هذا العنوان شــيئان الأولي لفظة المسمي" ، فبعد أن بذكر اسم الكتاب يلحقها بنلك اللفظة المبنية للمجهول فمن سماه إذن؟ و الثاني هذا العنوان المسجع في كل من لفظـــة " نزهة - فرحة " ، "القلوب- المكروب" فهو أقرب إلى أثنكال الكتــب فـي عهود الدول المنتابعة ، وبعيد عن روح المؤلف و العصر ، و المؤلف فـي

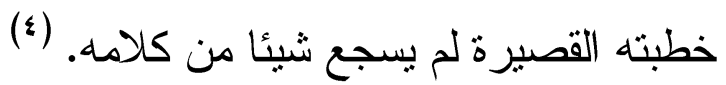

أما في العصر الحديث فيتبدي اسم الكتاب في عدة أشكال :1- غريب القرآن فقد ذكر الزركنـي " غريــب القــر آنـط" علـي

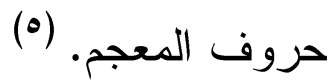

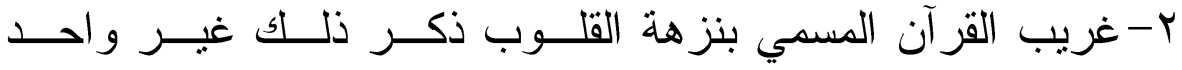
كالدكتور نصار (") ، و الدكتور / علي شو اخ و غير هها.

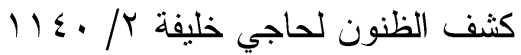

$$
\begin{aligned}
& 19 \leq 0 / \% \text { ، ، ، } \\
& \text { غريب القرآن للطريحي صــ }
\end{aligned}
$$

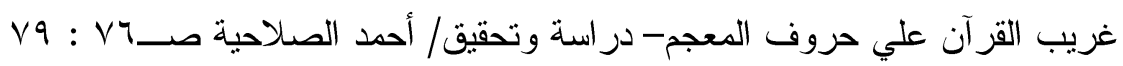

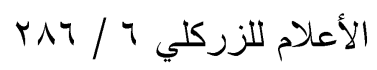

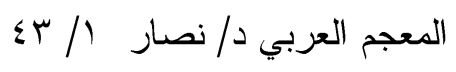


ب-" نز هة القلوب في تقسير القرآن "كما ذكر ذلــــ إبــــاعيل باثــــا

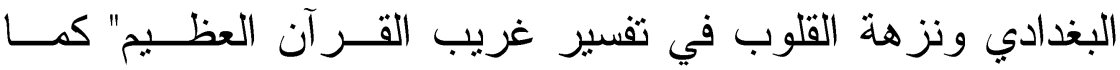
ذكر ه/عمر رضا كحالة. (1)

ثم قال المحقـتق بعــد أن أورد مســميات أخـربي عديــدة لهــذا الكتاب ، و أخير ا فان أغلــب فهــارس المخطوطــات فـي العــالم التـي

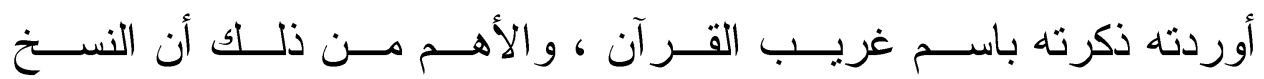

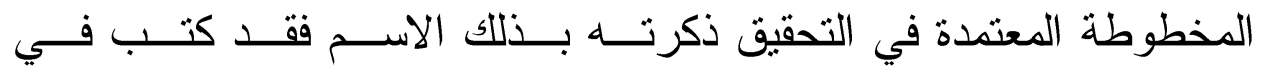

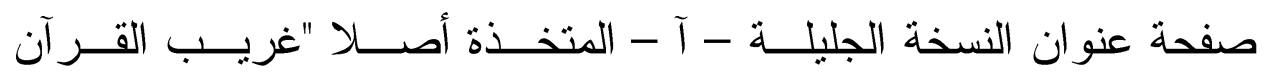
علي حروف المعجم" ، وفي النســذة القيمــة - ب - " تفســبر غريــب

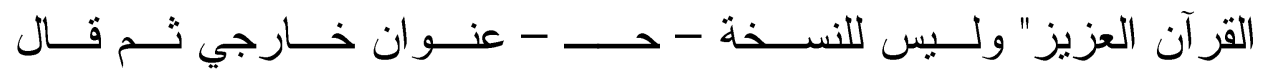
المحقق : بعد ذلك كله اطمأن قلبـي إلـى الاســم الأول ، و اســثر بـي الر أي علي العنوان المكتـوب علـي النســخة النفيســة التـي اتخـــتها أصلا وهو : غريب القرآن علي حروف المعجم"(r)

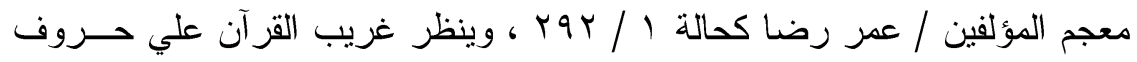

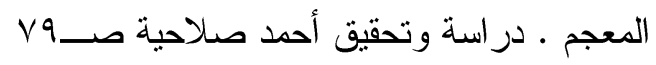




\section{وقفة مع المدلول اللغوي والاصطلاحي لكلمة " غريب " :}

يشير المدلول اللغوي لكلمة غريب إلى الغموض والإبهــام وعــدم

الوضوح يقول الزمخشري "تكلم فأغرب إذا جاء بغر ائب الكلام ونــــ ادره ، ويقول فلان يغرب كلامه ويغرب فيه ، وفي كلامه غرابه ، وغرب كلامه وقد غربت هذه الكلمة أبي غمضت فهي غريبة ــ ومنه مصنف الغريــب ، وقول الأعرابي : لبس هذا بغريب ، ولكنكم في الأدب غربــاء"(1) ، كمـــا

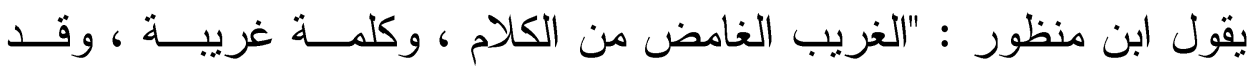
غربت ، وهو من ذلك "(r) ، وقد نقل حاجي خليفة عن الإمام أبي سـليمان حمد بن محمد الخطابي تعريفه للغريب فقال " الغريب من الكلام إنما هـــ الغامض البعيد من الفهم كما أن الغريب من الناس إنما هـــو البعيــد عــن الوطن المنقطع عن الأهل ، و الغريب من الكلام يقال علي وجهين أحــدها أن ير اد به أنه بعيد المعني غامض لا يتناوله الفهم إلا عن بعد ومعاناه فكر ، و الوجة الآخر أن ير اد به كلام من بعدت به الدار من شو اذ قبائل العرب

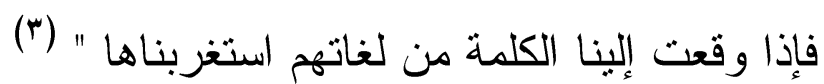

\section{المقصود بغريب القزآن :-}

نتبين مما سبق أن المعني اللغوي لكلمة "غريــبـ" يتشــع لبثـــل الوحشي ، و النافر و المهجور و الثاذ و غير المألوف و القر آن منزه عن ذلك خلو منه لأنه مخل بالفصاحة، وهو مقياس الفصاحة ، ومعيار البيان ولذلك

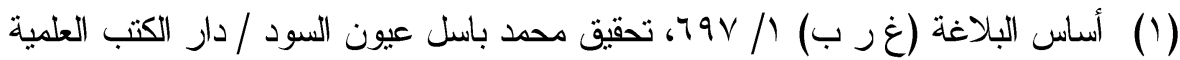

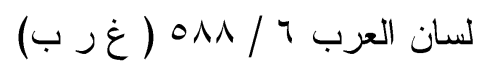

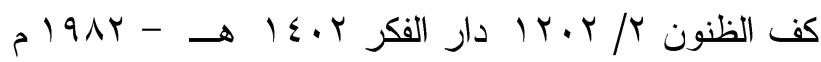


يقول الر افحي " في القر آن الفاظ اصطلح العلماء علي تسميتها بالغر ائـبـ ، وليس المر اد بغر ابتها أنها منكرة أو نافرة أو شاذة فان القرآن منزه عن هذا جميعا ، و إنما اللفظة الغريبة ههنا هي التي تكون حســنة مســنغربة فــي التأويل بحيث لا يتساوي في العلم بها أهلها وسائر الناس" (1) منهج المؤلف في عرض مادة هذا الكتاب :

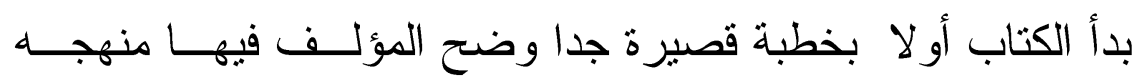

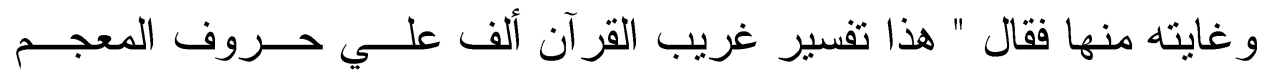
ليقرب تتاوله ويسهل حفظه علي دن أر اده " ، وقد قام هذا المـــهج علــي ترتيب الألفاظ الغريبة في القرآن الكريم علي حروف الهجاء مع زيادة اللام ألف قبل الياء وفق أو ائلها(r) فقط دون العودة بها إلى أصـــولها الاثـــقاقية وردها إلى حروفها الأصلية ، وحذف الزوائد منها بل ذكر ها كما هي فـي القرآن وصنفها علي ظاهر لفظها حسب الحروف الأول فقط ، ولم يـراع ترنيب الحرف الثاني وما بعده ، و هذه الطريقة يسيره سهلة علـي العامــة الذين لا يحسنون إرجاع المواد إلى أصولها . كما قسم كل حرف ثناثة أبو اب(") حسب الحركات الإعر ابية الثناث

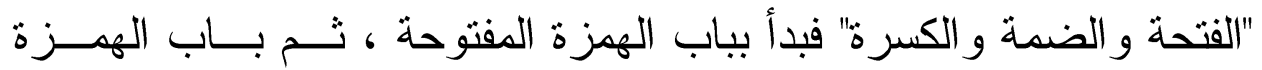
المضدومة ثم باب الهمزة المكسورة ثم باب الهززة المكسورة ثم باب الباء المفتوحة فالمضمومة فالمكسورة....الخ ، ولذلك يقول الـدكتور /حسـين

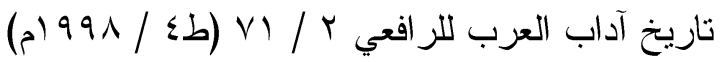

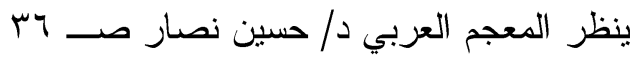

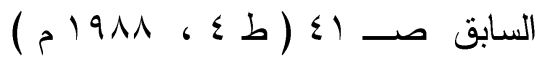


نصار أما النزتيب الألف بائي فابتدأ معقدا عند العزيزي في القرن الرابـع

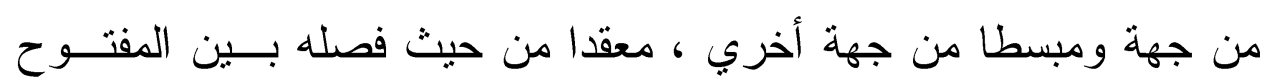

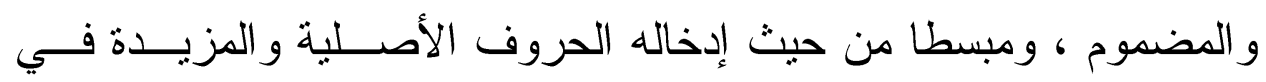

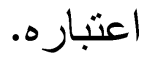

غير أنه يؤخذ علي هذا المنهج أنه لم يرتب الكلمات المبدو عة بحرف

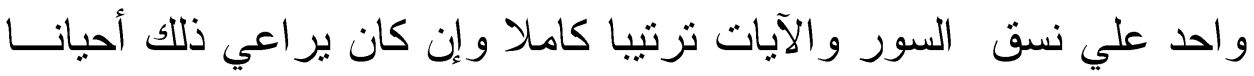
مما جعل الحصول علي الكلمة المطلوبة صعبا نوعا ما. (1) 


\section{الباب الأول}

\section{الدرس الصوتي في غريب القرآن}

السجستاني

ويشتمل علي أربعة فصول :

$$
\text { - الفصل الأول : الإدغــام }
$$

- الفصل الثاني : المخالفة الصوتية

- الفصل الثالث : الإبـــدال

- الفصل الرابع : تخفيف الهمز وتحقيقه 
$-0.19$

الفصل الأول

الإدغ 
من الظواهر الصونية التي عالجها السجستاني في كتابــهـ "غريــبـ

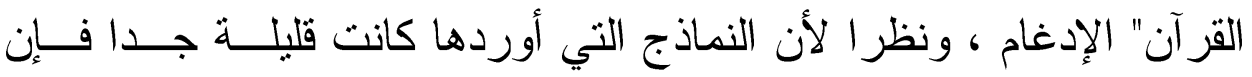

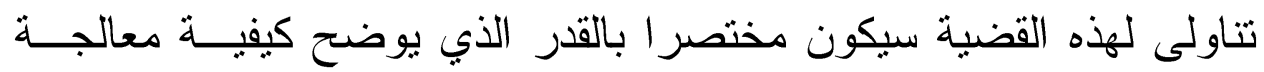
المؤلف لهذه القضية.

و الإدغام في اللغة " إدخال شيء في شيء ، يقال أدغدت اللجام في

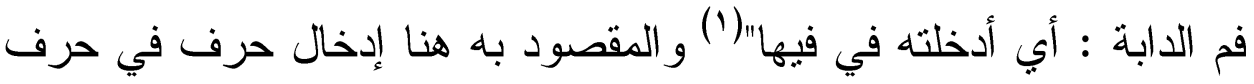

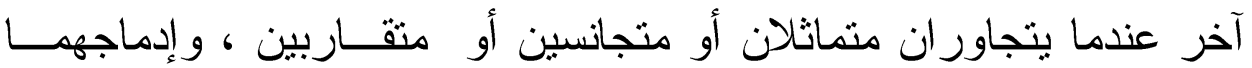

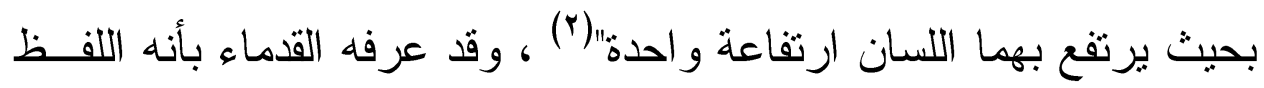

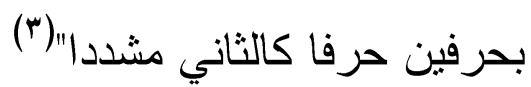

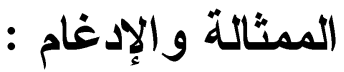

عالج القدماء ظاهرة المماتلة عند حديثهم عن الإدغام نحت مسميات أخر

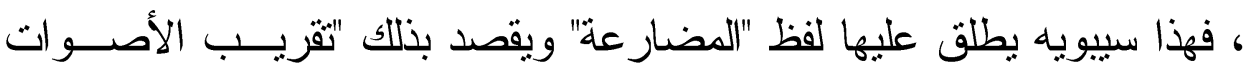

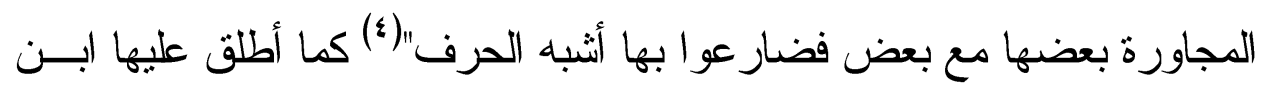

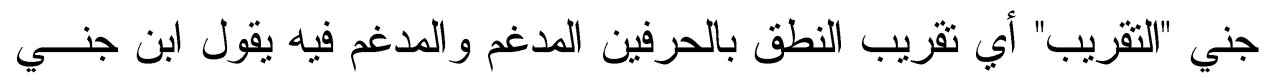

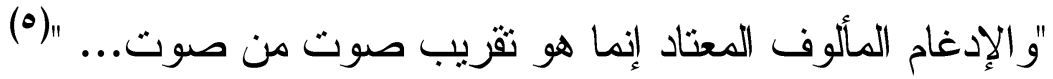

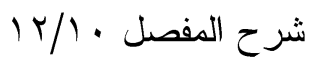

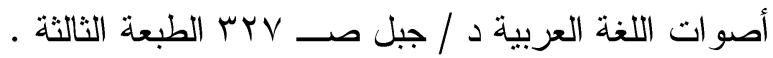

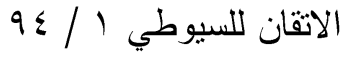

$$
\begin{aligned}
& \text { الكتاب ع / } \\
& \text { الخصائص / / I ( }
\end{aligned}
$$


كما أخذ المحدثون هذه الظاهرة عــن القــدماء ، و أطلقـــو ا عليهـــا مصطلح المماثلة ، إلا أن الدكتور / أنيس كان يؤثز اســتعمال المصــطلح القديم "الإدغام" فقال "نؤثز هنا استعمال هذا الإصطلاح القديم ، ونعني به ما بشير إليه المحدثون من نأثنر الأصو ات ببعضها حين تتجــاور ، ويســى المحدثون هذه الظاهرة اللغوي بالمماثلة لأن شرط تأثز الأصوات المتجاورة بعضها ببعض أن نكون منشابهة في المخرج أو الصــفة ، فـــاذا اجتـــع

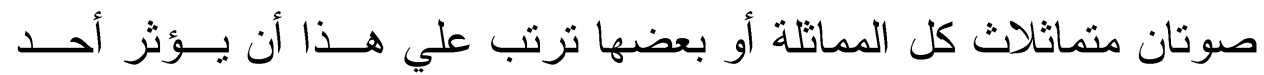
الصوتين في الآخر تأثير ا تختلف نسبته تبعا للظروف اللغوية الخاصة بلغة

من اللغات"(1)

كما ذكر الدكتور / أنيس أن الدافع الأساسي في الميل إلى المماتلـــة هو الاقتصاد في الجهد العضلي فقال" ... و لا شك أن فناء صوت في آخر

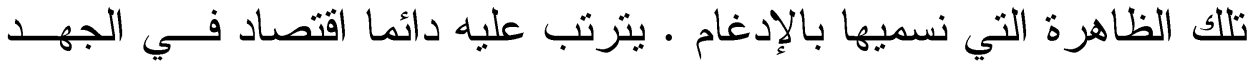
العضلي ، و الوصول بالنطق إلى مرماه من أقصر الطرق" (r) هذا وقد قسم المحدثون تأثز الأصوات إلى نوعين : 1- رجعي : وفيه يتأثز الصوت الأول بالثاني. r- تقدمي : وفيه بتأثز الصوت الثاني بالأول .

انظر في اللهجات العربية د/ أنيس صـ • V ، مكتبة الانجلو المصـرية / الطبعـة

$$
\text { التاسعة } 990
$$

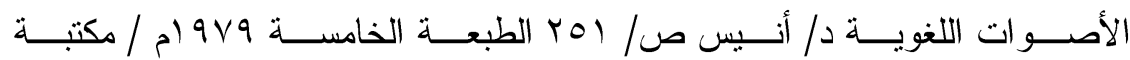


وتختلف اللهجات في الخضوع لنوع من هــذين النــوعين ، فـــن

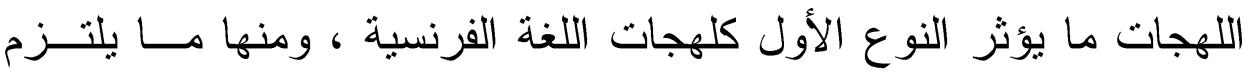
النوع الثاني كلهجات اللغة الإنجليزية وقد اثتملت اللغة العربية علي هذين النوعين من التأنز ، و إن كان النوع الأول أكثر شيوعا فيها ، ولم بعـرض المـ القز اء في كتبهم إلا للنوع الأول : أي التأثز الرجعي ، وهو الذي فيه يتأثز الصوت الأول بالثاني تأثز اكاملا بيزتب عليه أن بفني الصوت الأول فـي الثاني بحيث بنطق بالصوتنن صونا و احدا كالثاني. (1) وقد قسم العلماء الإدغام إلى كبير وصغير فالكبير : وهــو الــذي يفصل فيه بين الصوتين الساكنين صوت لين قصبر (أي حركة) وقد نسب هذا الإدغام إلى أبي عمرو بن العلاء أحد القراء السبعة وهذا النــوع مــن الإدغام بيطلب عمليات صوتية معقدة قبل أن بتحقق.

أما الإدغام الصغير : ففية يتجاور الصوتان الساكنان ، دون فاصل من أصوات اللين ، وهو الذي شاع في معظم اللغات ، لأن شــرط تــأثز صوت بآخر هو التفاؤهما التفاء مباشر ا .... ، و الإدغام أو تأثز الأصــوات المتجاورة بعضها ببعض ، ظاهرة صوتية تحدث كثير ا في البيئات البدائية حيث السرعة في نطق الكلمات ، ومزجها بعضها بــبعض ، فــلا بعطـي الحرف حقه الصوتي من تحقيق أو تجوبد في النطق به "(r)

$$
\begin{aligned}
& \text { V • في اللهجات العربية صـ } \\
& \text { السابق صـ ل V بتصرف يسير }
\end{aligned}
$$




\section{ما بقع فيه الإدغام}

يقع الإدغام بين المتماثلين ، و المتفاربين ، و المتجانسين ، فــالمثنان هما الحرفان اللذان اتخدا مخرجا وصفة كالباعين، و التائين ، و الجمـين (1)

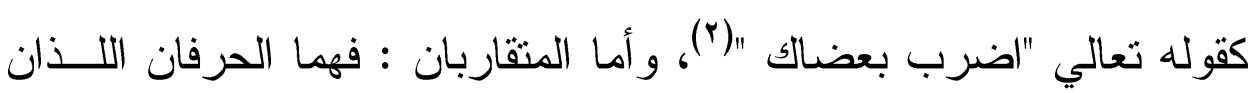
تقاربا مخرجا وصفة أو مخرجا لاصفة أو صفة لا مخرجا كاللام والــر اء و الدال و الشين ، و المتجانسان : هما الحرفان اللذان اتحدا مخرجا و اختلفـا

صفة كالدال و التاء نحو : قد تنين. (r) الإدغام عند السجستاني :

عندما درست الإدغام عند السجستاني من خلآل مصنفه القيم "غريب القر آن" وجدته وإن كان قد نص علي الإدغام فيه صــر احة إلا أن أمثلــــة

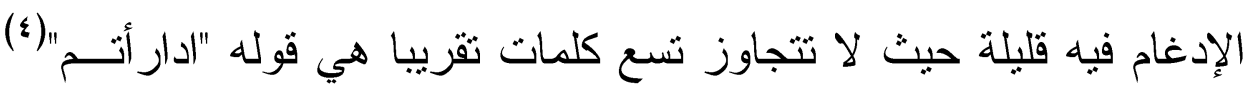
و أصله : تدار أنم : أي تدافعتم واختلفتم في القتيل : أي ألقي بعضهم علـي بعض فأدغمت التاء في الدال لأنهما من مخرج و احد فلما أدغمت ســكنت

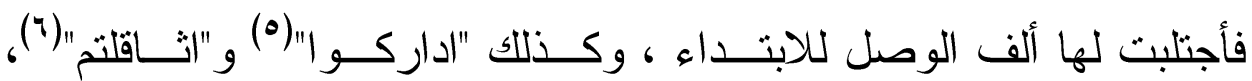
"اطيرنا"(V) وما أشبه ذللك"(^)

$$
\begin{aligned}
& \text { النشر IVA/| } \\
& \text { بعض آية من سورة البقرة ( • ؟) ، وسورة الثعر اء رقم(بآ) }
\end{aligned}
$$

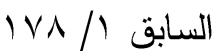

$$
\begin{aligned}
& \text { من سورة البقرة آية (VY) } \\
& \text { من سورة الأعر اف آية (rᄉ) } \\
& \text { من سورة التوبة آية (بر) } \\
& \text { من سورة النمل آية (§V) }
\end{aligned}
$$

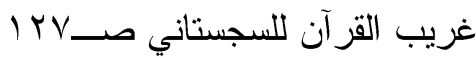


وقوله " مزمل" ملتف في ثيابه ، و أصله متزمل فأدغمت التاء فــي

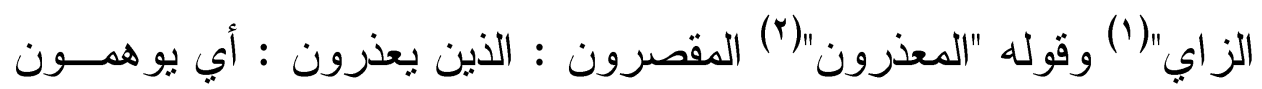
أن لهم عذر ا، ولا عذر لهم معذرون : معتذرون أدغمت التاء في الذال"(") هذا ومن الجدير بالذكر أن هذه الكلمات تتدرج كلها تحـــت إدغــام

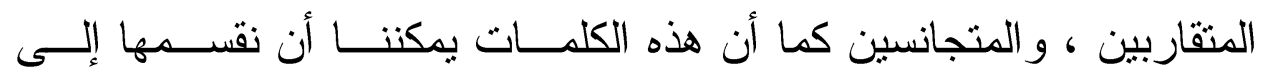

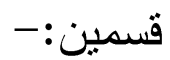

القسم الأول : أدغمت فيه تاء تفعل وتفاعل في فائها ، وينــدرج

تحت هذا القسم الكلمات التالية : اطير - اثاقل - إدارأنم - اداركــوا يطهر - مزمل.

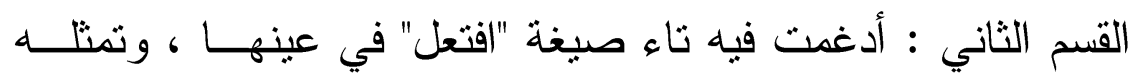
الكلمات التالية : يخصمون - يهدى - معذرون.

نلاحظ أن القسم الأول و الثاني يندرجان تحت ما بسمي بالتقريب أو

المماثلة ، وقد عالج الأئمة القدماء - و علي راسهم سيبويه و ابن جني كما رأينا - هذه الظاهرة مدركين هدفها ، وهو التخفيف ، وتيسير الكلام.

وبيان ذلك أنه بالنسبة للألفاظ التي تتدرج تحت القسم الأول ، وهو ادغام تاء "تفعل" و "تفاعل" في فائها وهو كل ما كانت فيه فاء صيغة "تفعل" أو "تفاعل" أحد حروف طرف اللسان أو مقدمه التالية : د ث ط / ز س ص هـ / ث ذ ظ / ض / ش ج " فإن تاء صيغة "تفعل" أو "تفاعل" بجوز إدغامها

$$
\begin{aligned}
& \text { السابق صـ rrr } \\
& \text { من سورة التوبة آية (، (9) } \\
& \text { غريب القرآن صـــ דبr }
\end{aligned}
$$


في فائهما التي من نتلك الحروف تخففا من التقل الذي يسببه نو الي حــرفين مثقاربين في المخرج لأن مفارفة اللسان لمخرج التاء - بعد نطقهــا - ثـــ عودته إلبه أو إلى قريب منه لنطق أبي من ثلك الحروف يشبه مشى المقبد الذي يرفع رجله ليخطو إلى الأمام فيمنعه القيد فيعود بها إلى مكانها نفسه-

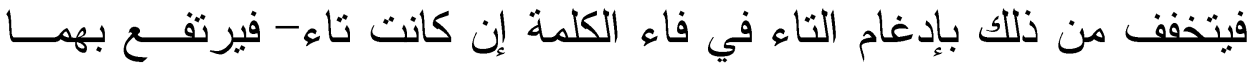
اللسان ارتفاعه و احدة ، أو بإبدال التاء حرفا مماثلا لحرف فاء الكلمة - ثم يدغم في فاء الكلمة وينطقان بارتفاعة و احدة للسان كذلك ، وهعـروف أن الإدغام لايتم إلا بإسكان الحرف الأول المدغم ، وهذا الحــرف الأول هــــ هـ التاء التي تبدأ بها الكلمة ، و لا يبتدأ بساكن ، ولذا يجتلبون هــزة وصــل ليبتدؤ ا بها قبل الساكن إن أر ادوا الإدغام.

وبناء علي ذلك يقال في تطير : اطير ، وفي نثاقل : اثاقل : وفـي تدارأ : ادارأ ، وفي تدرالك : ادارك ، وفي بتطهر : بطهر ، وفي منزمل : مزمل . فالتأثز كما نري في هذه الكلمات رجعي. (1) أمـا بالنسبة للألفاظ التي تتدرج تحت القسم الثاني وهو ادغــام تـــاء صيغة "افتحل" في عينها ، وذلك إذا كانت عين صيغة "افنعل" أحد حـروف طرف اللسان الآتية : د ت ط / ز س ص / ث ذ ط/ ض جاز إسكان تاء افتعل ، و إدغامها في الحرف الواقع عينا للكلمة من تلك الحروف بعد إبدال تاء افتعل حرفا مماثلا للحرف الو اقع عينا - إن لم يكن ذلك الحـرف تــاء و إلا بقيث التاء فيرتفع بها اللسان ارتفاعة و احدة ، وذلك تخفقا مــن التقـلـ الو اقع من نو اليهما دع قرب مخرجيها .... وعند إسكان التاء للإدغام تنقل 
حركتها الفتحة إلى فاء افتحل الساكنة ، وبتحرك الفاء هكذا يســتغني عـن همزة الوصل التي في أول الصيغة لأنها إنما جئ بها ليمكن الابتداء بفــاء افتعل الساكنة وعلي ذلك بقال في يختصمون: يخصمون ، وفي يهنـدي : يهدي ، وفي معنذرون معذرون و هكذا نري أن التأثز في هذه الكلمات تأثز رجعي.

ونفهم من هذا أن الصوت الأضعف تأثز بما هو أقوي منه في هذه الأمثلة وما سبقها فمثلا اطبر أصلها تطير أبدلت التاء طاء ثم أدعمت الطاء في الطاء حيث أدغم الحرف الأضعف الساكن وهو الطـــاء الأولـي فــي المتحرك الأقوي وهو الطاء الثانية فصارت اطبر ، وكذلك الحال في يهدي

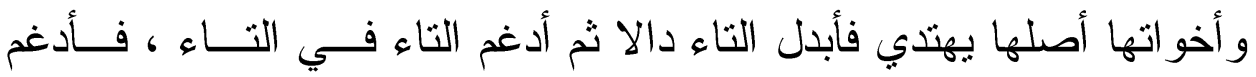
الحرف الأضعف الساكن وهو الدال الأولي في المتحرك الأقوي وهو الدال الثانية فصارت يهدي

ولقد أوضـح المحدثون مدي صلة الممانلة بالإدغام ، ولــذلك يقــــل الدكتور / أحمد مختار عمر " إن الممانلة تعني إز الة الحدود بين الصوتين

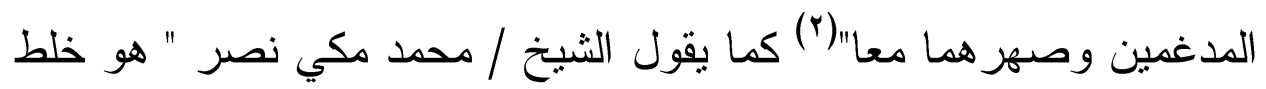
الحرفين المتمانتين أو المتقاربين أو المتجانسين فيصير ان حرفا و احدا مشددا ، برتفع اللسان عند النطق بهما ارتفاعة واحدة " (ب) فالصــلـة قوبـــة بــين الادغام و الممانتة.

$$
\text { Y السابق صـ }
$$

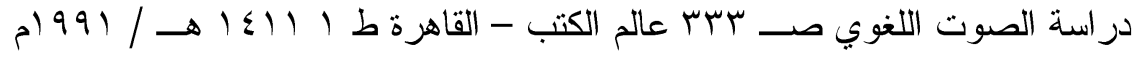

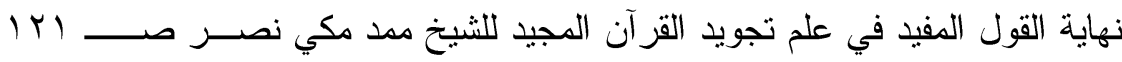

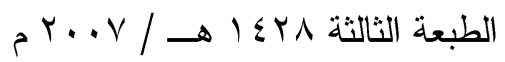


$-0.9 \leq-$

الفصل الثاني

المفــالفــة الصوتيسـة عنســ

السجستاني 


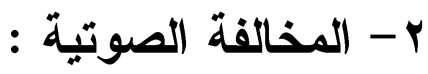

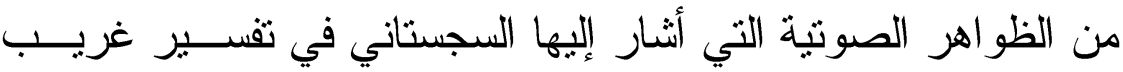

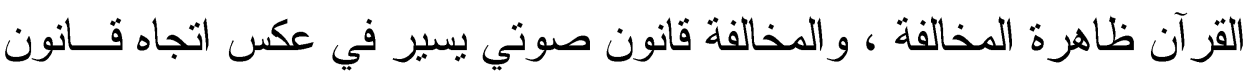

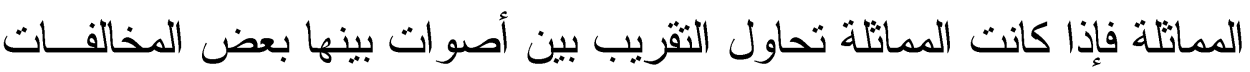

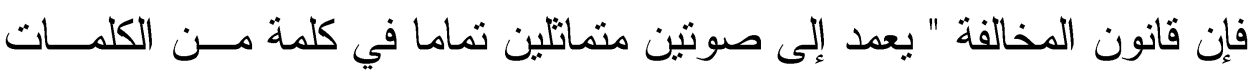

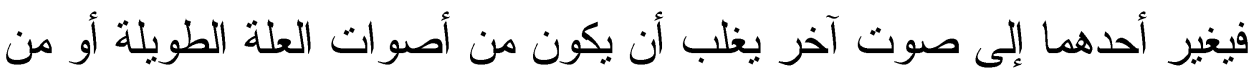

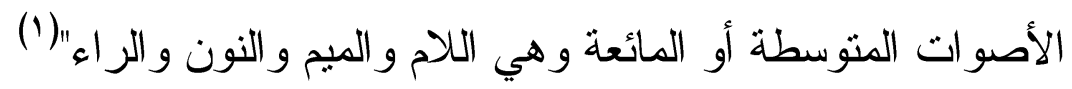
معني ذلك أن المخالفة تعني نغير أحد الصوتين المنماتلين في الكلمة

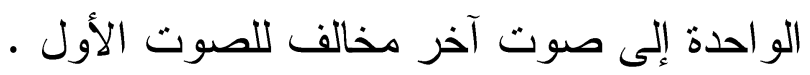

وقد فطن قدماء اللغويين العرب لهذه الظاهرة ، وكانو ا يعبرون عنها

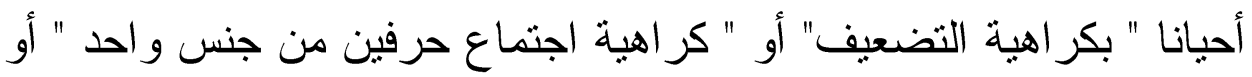

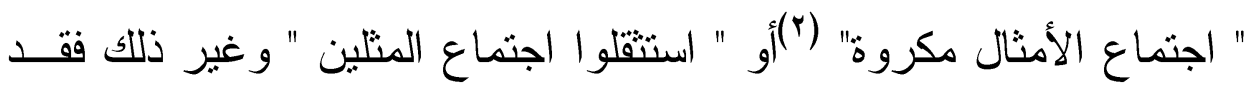

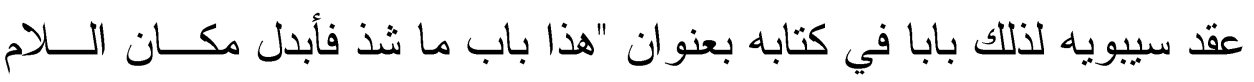

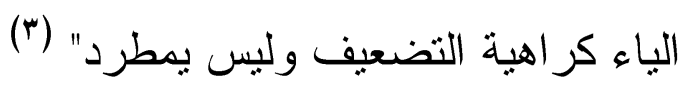

ويسميها الخليل بن أحمد : الاختلاف فيما روب عنه الأزهرب(أ) في قوله " و أما مهما فإن النحويين زعموا أن أصل مهما : ماما ، ولكن أبدلوا التطور اللغوي مظاهره و علله وقو انينه د/ رمضان عبدالتواب صـ V V بتصـرف الطبعة الثالثة / مكتبة الخانجي.

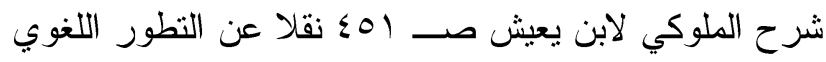

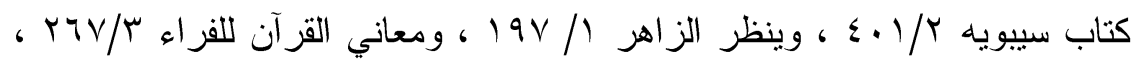

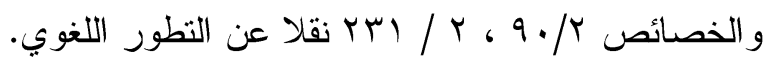

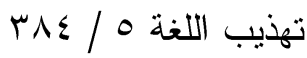


من الألف الأولي ها ليختلط اللفظ ، وقد اختلفت الرواية عن الخليل في هذه النقطة عند السيوطي الذي يقول " وقال الخليل أصل مهما الثرطية : ماما

$$
\text { قلبو ا الأولي هاء لاستقباح التكرير"(1) }
$$

هذا ويري الدكتور / أنبس أن كلا من المماثلة و المخالفة تهدف إلى

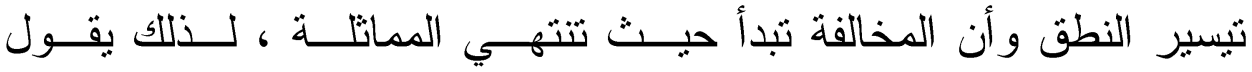

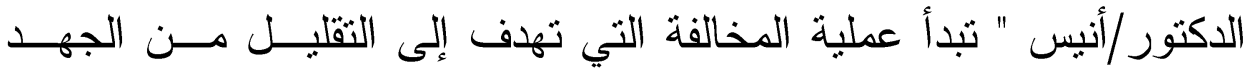

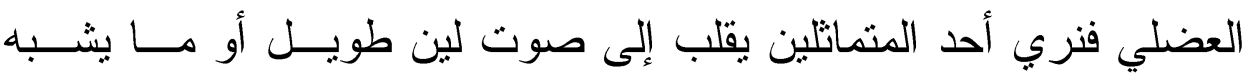

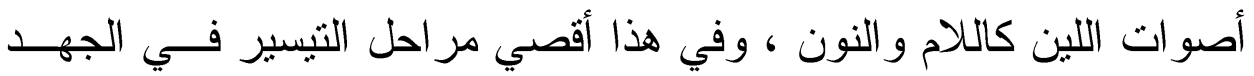

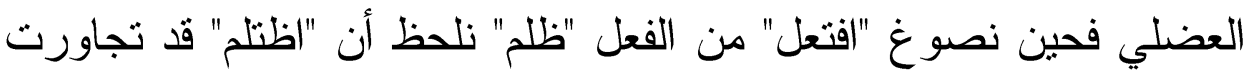
فيها الظاء و التاء و هما مختلفان في الجهر و الههـس و الثـــدة و الرخــاوة

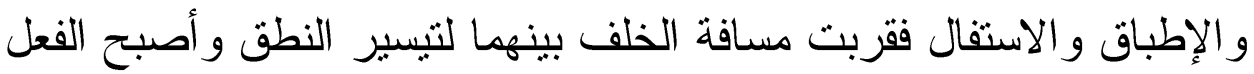
"اظللم" وهكذا نمانل الصونان وهو أقصـي ما بصل إليه التيسير في عمليــة

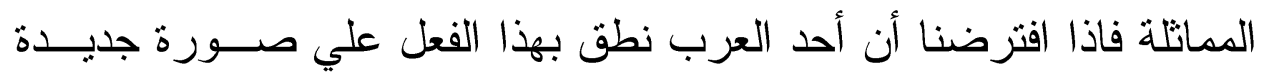

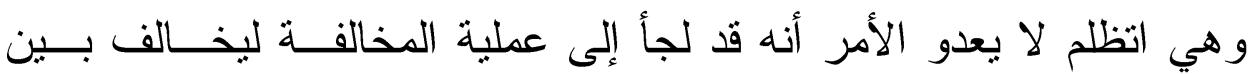
الظاعين المتجاورين بأن استبدل باحداهما نونا ليزداد النطق تيسير ا" (r) إذن " سبب المخالفة من الناحية الصوتية هـــو أن أحــــ الصـــوتين المنماتلين يحتاجان إلي جهد عضلي في النطق بهما فـي كلمــة و احــدة ،

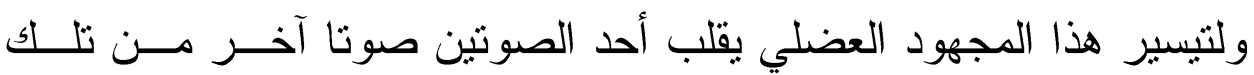
الأصو ات التي لا تتطلب مجهودا عضليا كاللام و الميم و النون"(")

$$
\begin{aligned}
& \text { الأشباه و النظائر / / 1 / مثلا عن التطور اللغوي }
\end{aligned}
$$

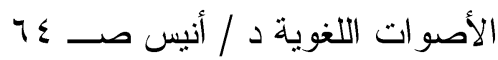

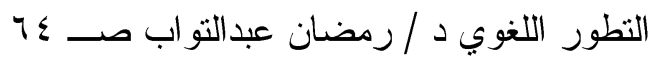




\section{المخالفة الصوتية عند السجستاني :}

لقد فطن السجستاني إلى هذه الظاهرة الصوتية ، و عالجها في أكثـر

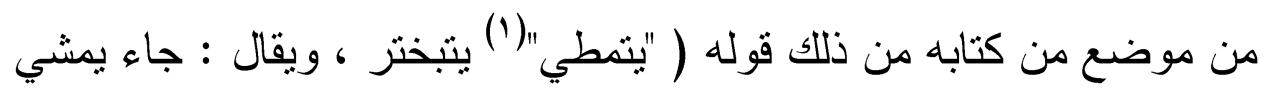

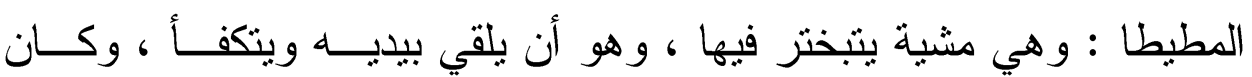

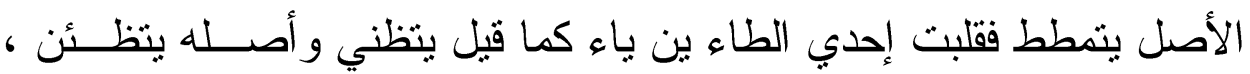

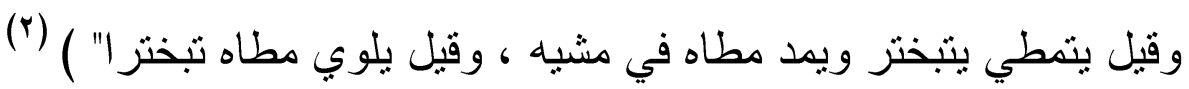
نتبين من ذلك أن الطاء الأخيرة من الفعل "تمطط" أبدلت باء لأنها

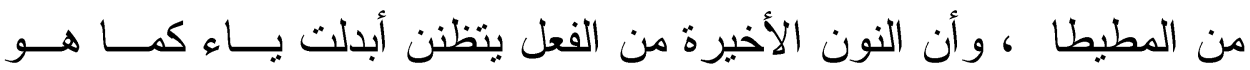

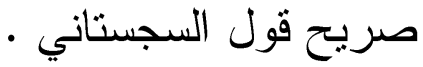

كما يقول أيضا "دساها"(") دسي نفسه: أي أخفاها بالفجور و المعاصي

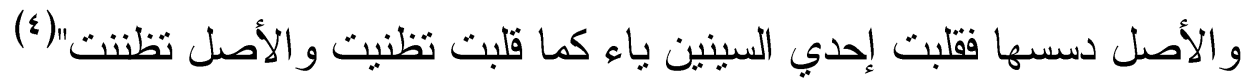
و هنا تحققت المخالفة بقلب إحدي السينين باء كما أثنار المؤلف إلى

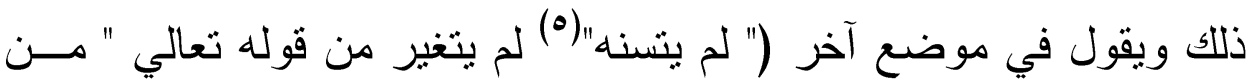

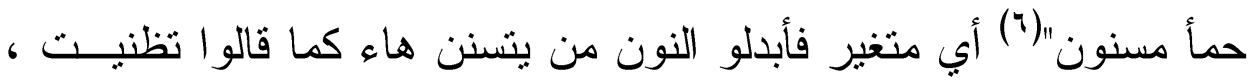

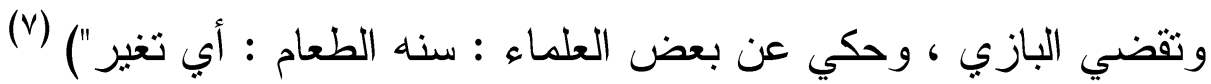

$$
\begin{aligned}
& \text { من سورة القيامة آية سب } \\
& \text { غريب القز آن صـــــ لرحه } \\
& \text { من سورة الثمس آية . } \\
& \text { غريب القرآن صـــ ع } 19 \\
& \text { من سورة البقرة آية (ro9) } \\
& \text { من سورة الحجر آية (T؟Y) }
\end{aligned}
$$

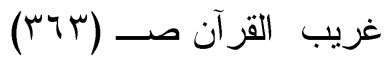


كما نلاحظ أيضـا أن المخالفة الصوتية تحققت هنـــا بقلـب أحــدي المنلين - وهو النون الأخيرة من الفعل يتسنن - هاء كما حدث في كل مــن الفعل تظنتت وتقضيت اللذين أصلهما تظننت وتقضضيت فأبــدلت النــون الأخيرة من الفعل تظنيت ، وكذا الضاد الأخيرة من الفعل تقضضــت بـــاء

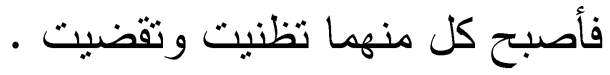

ويقول أيضا ( " صلصال"(1) طين يابس لم يطبخ إذا نقرته صل

: اي صوت من يبسه كما يصوت الفخار .... ويقال الصلصال : المنـنت

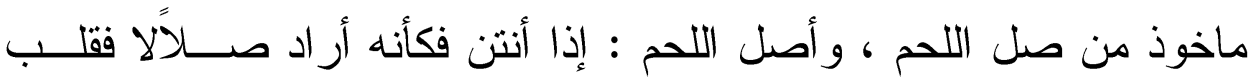

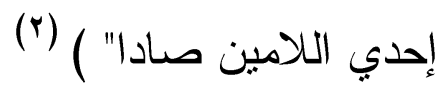

كما نلاحظ أن المخالفة الصوتية تحققت هنا بإبدال اللام الثانية مـن

$$
\text { كلمة "صلالا" صادا فأصبحت "صلصال" وهكذا. }
$$

هذا ولعلنا نلاحظ من هذا كله أن السجستاني قد اســتخدم ظــاهرة المخالفة هذه وسيلة أيضا من وسائل كثف المعني وإيضاحه أبي أنه وظفها لتوضيح المعني ، ونلمس ذلك من خلال قوله " يتمطي: يتبخنز ..... و وهــو أن بلقي بيديه وينكفاً ، وكأن الأصل بتمطط قلبت إحدي الطاعين باء ...إخخ وقوله " دساها : دسي نفسه : أي أخفاها بالفجور و المعاصي ... إلخ وكذللك فحل في كل ما تبقي من أمثلة هذه الظاهرة التي أوردناها له.

$$
\begin{aligned}
& \text { من سورة الرحمن آية (ع ( ) }
\end{aligned}
$$

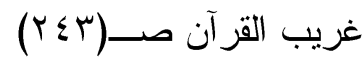


$-0.99-$

النصل الثالث

الإبـــــدال 
من القضايا الصوتية المهمة التي عالجها الإمام أبو بكر السجستاني في مؤلفه " غريب القرآن علي حروف المعجم" قضية "الإبدال" و الإبدال في اللغة "جعل شيء مكان آخر ، أو تغيير الصورة إلى صورة آخرى"(1).

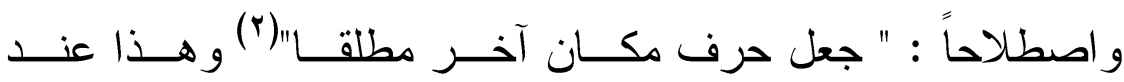
الصرفيين أما عن اللغويين فهو "جعل حرف مكان آخر أو حركــة مكــان أخري" (") أو "إبدال صوت من كلمة بصوت آخر "(๕) كما عرفه بعضهر بأنه " جعل حرف مكان حرف آخر من الكلمـــة الو احدة ، وفي موضعها منه لعلاقة بين الحرفين. (•) سبب الإبدال أو منشؤه :

اختلف العلماء في منشئه أهو من اختلاف اللهجات أم لا ؟ علي رأيين : 1- فأبو الطيب اللغوي ومن حذا حذوه يرون أن الإبــدال ينشــأ بســبـ اختلاف اللهجات فيقول "ليس المراد من الإبــدال أن تتعدــــ العــرب تعويض حرف من حرف ، و إنما هي لغات مختلفة لمعان متفقة تثقارب اللفظتان لمعني واحد ، إلى أن قال : و الاليل عي ذلك أن قبيلة و احدة لا تتكلم بكلمة طور ا مهوزة وطور ا غير مهمــوزة ، و لا بالصـــاد مــرة 
وبالسين أخري ، وكذلك إبدال لام التعريف ميما ، و الهمزة المصــدرة

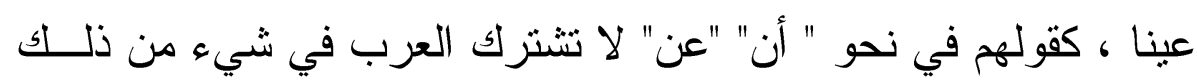

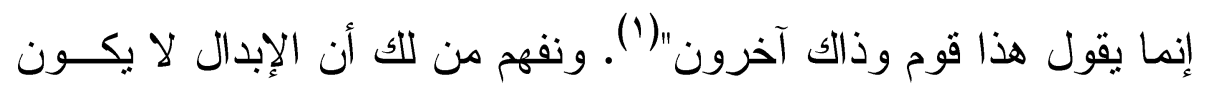
إلا من قبائل متعددة. (r)

r- أما ابن جني ، و ابن سبدة ، و ابن بعيش فيرون أن الكلمنين المتحــني المعني و الحروف إلا في حرف واحد ، ثارة يكون هذا الخلاف في ذلك الحرف من قبيل الإبدال عندهم ، وذلك إذا أمكن الحكم بأصالة إحـدي

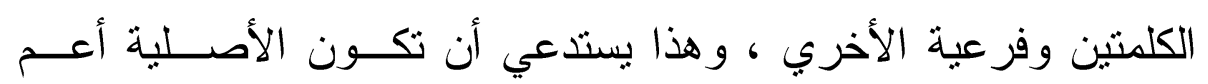

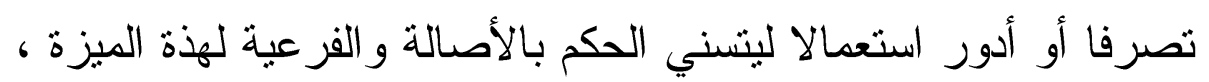

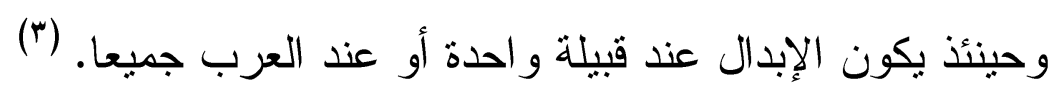
- وتارة يكون هذا الخلاف من قبيل اختلاف اللغات ، وذلك إذا لم بتســن الحكم و الفرعية لهذه الميزة ، وحينئذ يكون الإبدال عند قبيلة و احـدة أو ولئ عند العرب جميعا.

- وقد ناقش أستاذنا الدكتور / نجا - برحمه الله - هذا الر أي مبينا ضعفه فقال " ودن النظر إلى هذا الر أبي الذي اقتضي التفريق بـين الإبــــال

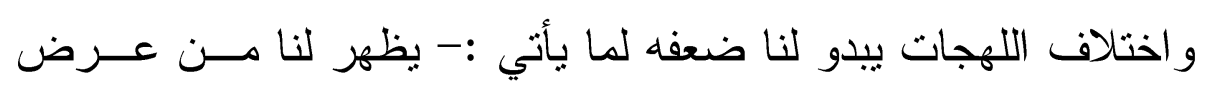

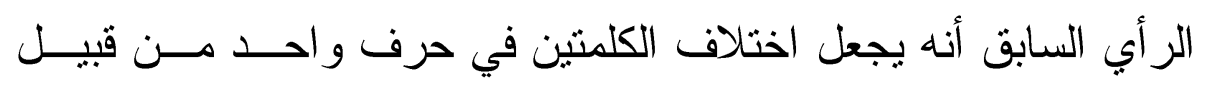
الإبدال ، إذا كانت إحدي الكلمتين أصلا للأخري ، بأن كانــث أكثـر

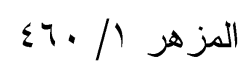

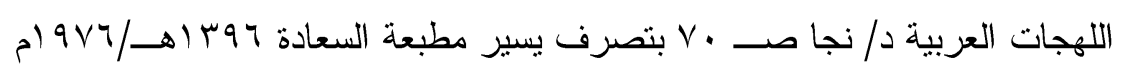

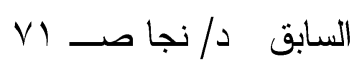


تصرفاً أو أدور استعمالا ، أو تحقق فيها كلا الأهــرين وهــو ظــــــر الضعف لما يأني:-

أولا : أن مقياس التصرف لا ينبغي أن يعول عليه لجواز أن تكون الكلمة

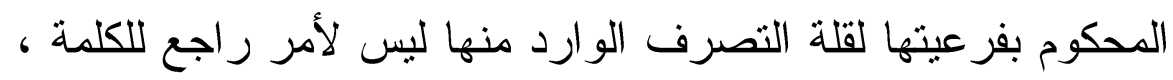

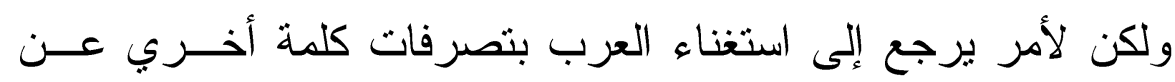

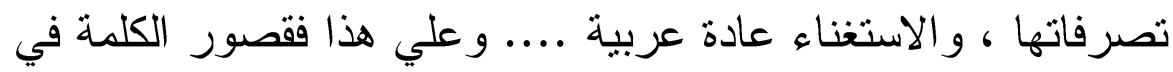

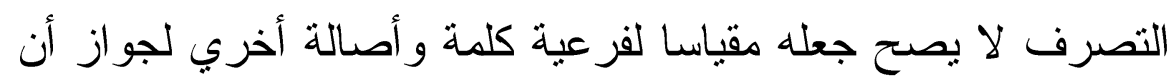
يكون الاستغناء قد نطرق إليها ـ

ثانيا : أن كثرة الأستعمال الذي يعتبره أصحاب هذا الر أي مقياسا للأصالة

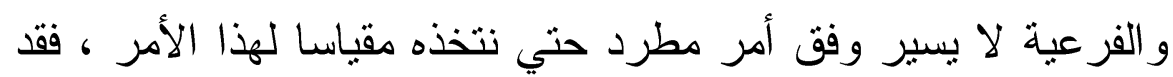

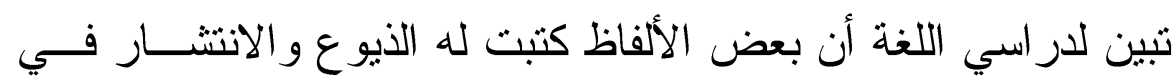

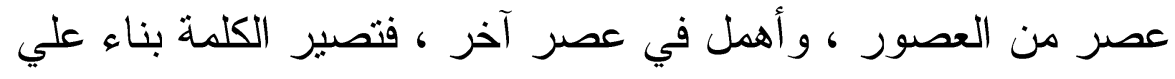

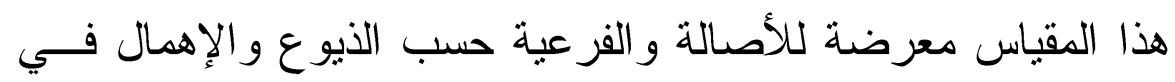

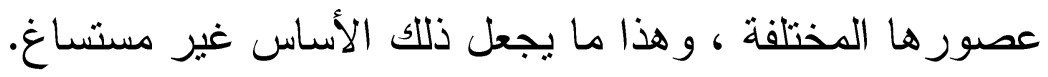

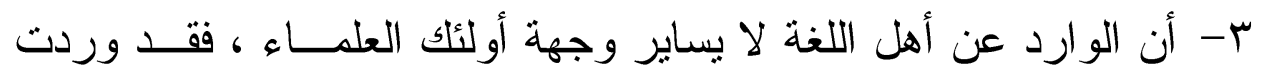

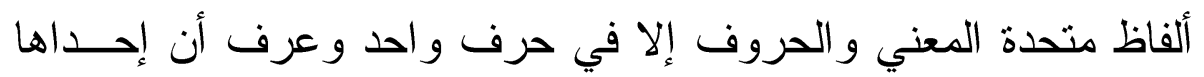

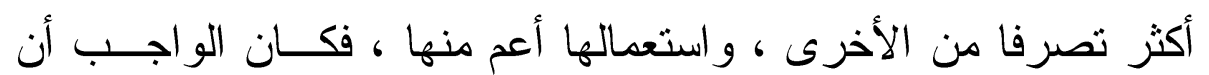

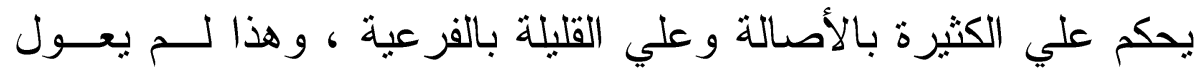


ع-ر ابعا : أن أصحاب ها الر أب قد تخلو ا عن التزامه فيما ورد عنهم مها

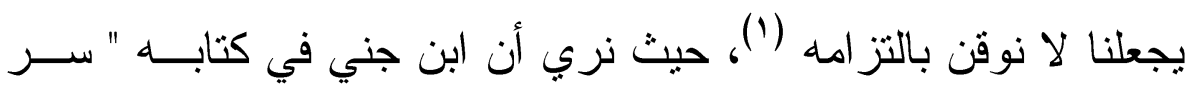

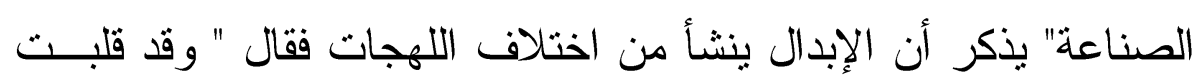

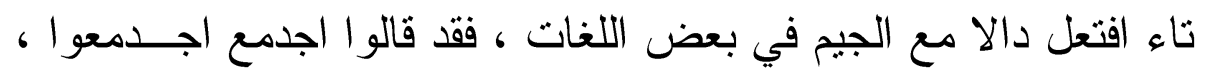

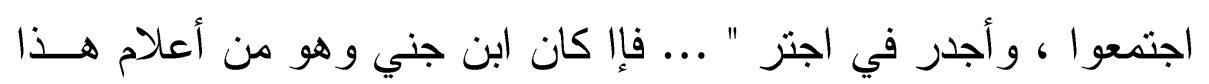

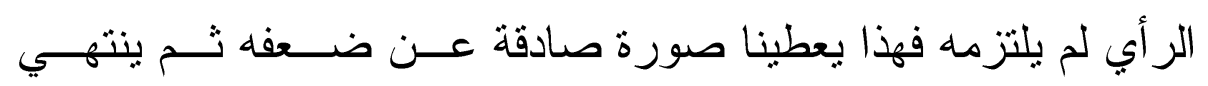

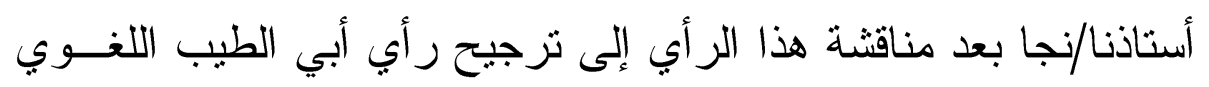

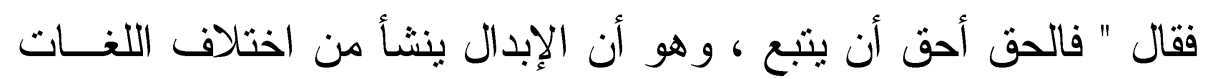

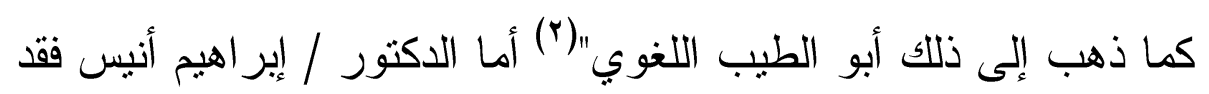

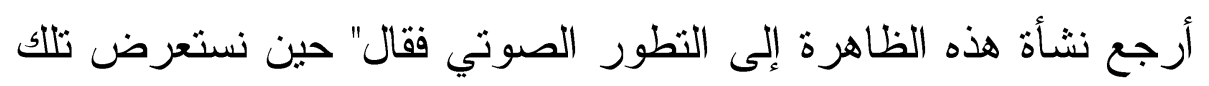

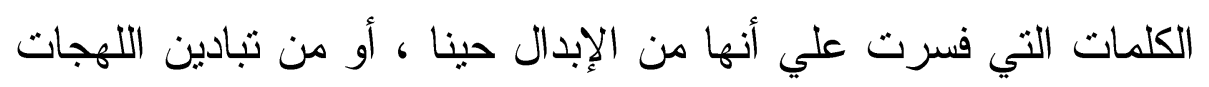

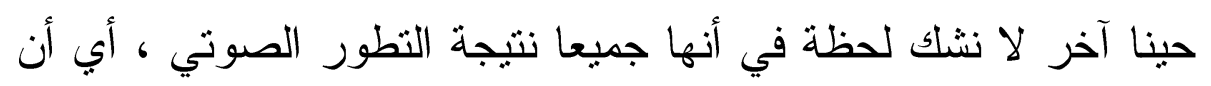

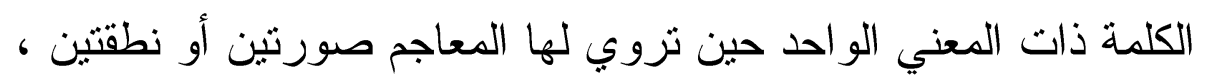

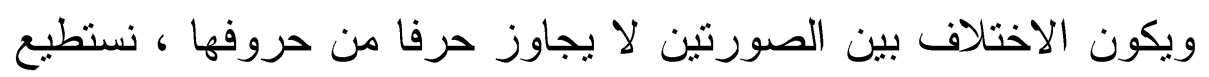

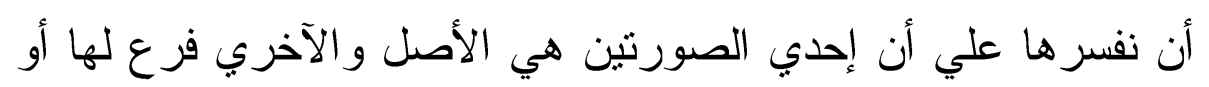

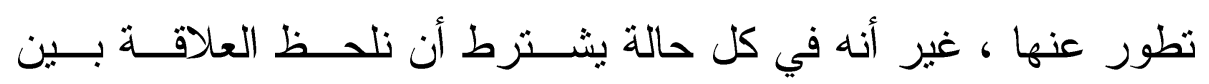

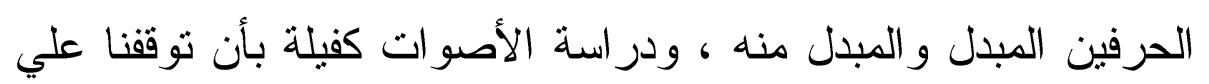

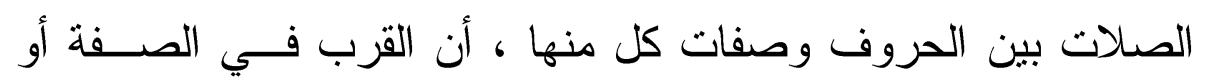

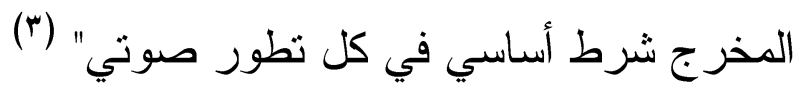

$$
\begin{aligned}
& \text { السابق صـ VY بتصرف يسير }
\end{aligned}
$$

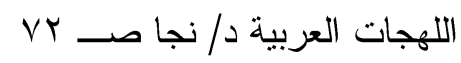

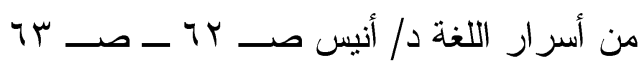


نتبين من ذلك انه يشتررط للحكم بالأصالة لإحدي الصــورثنين وأن الأخري فرع منها أو تطور عنها أن يكون هناك تقارب فـي ىالصــفة أو دئ المخرج كما نص علي ذلك الدكتور / أنيس.

وحينما قمت بفحص الأمثلة التي أوردها الإمام أبو بكر السجسناني وجدت أن منها ما هو متحد في المخرج و الصفة بين المبدل و المبدل منه ، كما أن منها ما ليس بينهما علاقة صونية . وسوف أقوم - بعونه نعالى - بعرض نماذج من عمل المؤلف في هذه الظاهرة فما انطبق عليه هذا الثرط حكمنا عليه بأنه من قبيل الإبدال ، ومالم بنطق عليه هذا الثرط أدرجناه تحت التصحيف أو التحريف أو التز ادف. أولا: نماذج الإبدال بين الصوامت بعضها من بعض في غريب القرآن للسجستاني إبال إل الهاء من الهمزة :

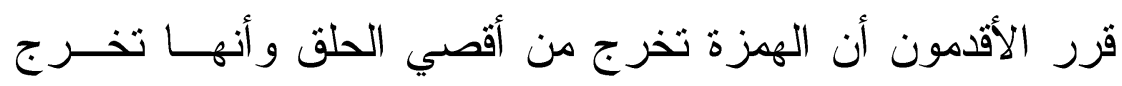
بعصر وضغط و انها أعمق الحروف مخرجا ، و أن الهــاء تشــاركها فــي المخرج(1) ، يقول سيبوبه بعد ما ساق طائفة من صور حذف الهززة تخفيفا " و اعلم أن الهززة إنما فعل بها هذا من لم بحققها لأنه بعد مخرجها، و لأنها نبرة في الصدر تخرج باجتهاد ، وهي أبعد الحروف مخرجا ، فنقل عليهم ذلك ( بعني تحقيق الههزة) لأنه كالتهوع " ومن أجل ثقل الهمزة المحققـة خفو ها بصور منعددة(r) كما أن الههزة شديدة ، وهذا لا خلاف فيه ولكـن فئن الخلاف بين القدماء و المحدثين في وصفها بالجهر و الهمس حيث قال القدماء

$$
\begin{aligned}
& \text { أصوات اللغة العربية د / جبل صــ • سا } \\
& \text { السابق صـ ع ז1 ، صـ 0سر }
\end{aligned}
$$


إنها مجهورة، وقال المدثثن إنها صــوت لا مجهـور ، و لا مهمــوس"(1) فالهمزة إذن صوت شديد ، مجهور عند القدماء ، ولـيس بــالمجهور، و لا بالمهوس عند المحدثين - كما ذكرنا - منفتح ، مستقل ، مصدت.

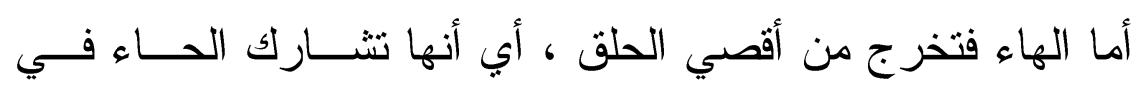
المخرج وقد وصفها الخليل بأنها " خفية لا صوت لها كما وصفها سيبيويه

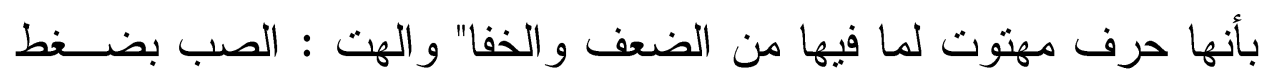
وقوة ذلك أن النفس يتدفق في خروج الهاء بقوة وانصباب ، فلا يسـتطاع الاستمر ار طويلا في نطقها ساكنة ، و الهاء رخوة ، كما أنها من الحــروف

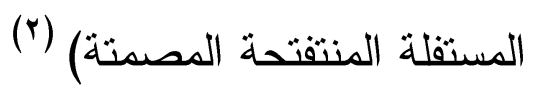

ولا شتر الك الهاء مع الهزةة في مخرج واحد - مع سهولة الهمزة -

$$
\text { كثر وقوع الإبدال بينهما (r). }
$$

هذا وقد وقع الإبدال بينهما عند السجستاني في ست كلمــات وهــي قوله " أصل مهيمن : مؤيمين : مفعيل من أمسـن ، يقــال فــان بطيــر ومبيطرمن البيطار فقلبت الهمزة هاء لقرب مخرجهما كما قالو أرقت الماء

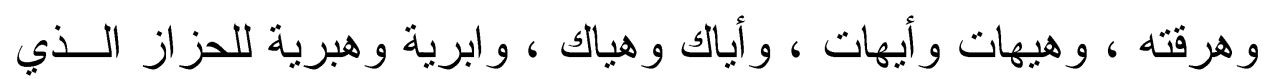

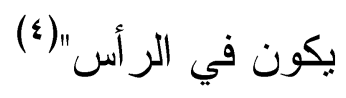

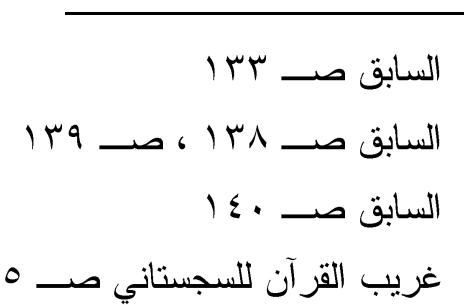

غريب القر آن للسجستاني صـ Oك ب دراسة وتحقيق أحمد عبدالقادر صلاحية . 
r- ابدال الثاء من الفاء :

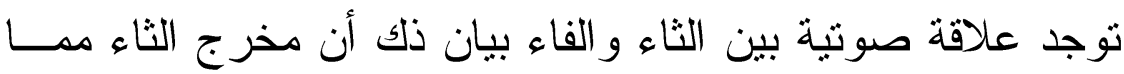
بين طرف اللسان و أطر اف الثنايا العليا ،أما مخرج الفاء فمن باطن الثــفة

السفلي و أطر اف الثنايا العليا. (1)

فالثاء : صوت أسناني احتكاكي ، مهوس ، و الفاء : صوت أسناني شفوي احتكاكي ، مهموس أيضا فكلاهما مهموس ، ورخو ، مستقل/ منتفخ ، مصمت فهذا التقارب بينهما في المخرج و الصفة هو الذي سوغ وقـوع الإبدال بينهما عند السجستاني ، وذلك في قوله " ... ويقال الفـوم : الثــوم أبدلت الثاء بالفاء كما قالو ا : جدث ، وجدف للقبر "(r) كما قال في موضع آخر " أجداث ، و أجداف قبور و احسـدها جــدث

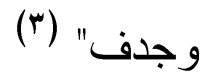

هذا وهن الجدير بالذكر أن إبدال الثاء دن الفاء لم يأت إلا في هــذه

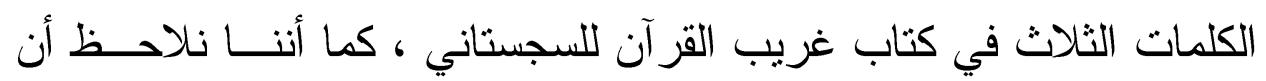
السجستاني لم ينسب الإبدال بين الثاء و الفاء إلى أبي من القبائل العربيــة ، وقد نسب الفيومي : النطق بالثاء إلى تميم ، كما نسب النطق بالفاء إلى أهل نجد فقال " الجدث : الفبر و الجمع أجداث مثل سبب وأسباب وهذه لغة تهامة ، و أما أهل نجد فيقولون جدف بالفاء" (ء)

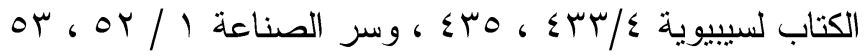

$$
\begin{aligned}
& \text { غريب القر آن للسجستاني صـ rیـ }
\end{aligned}
$$

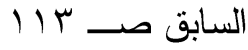

$$
\begin{aligned}
& \text { ينظر المصباح المنير صــــ بس " جدث" }
\end{aligned}
$$




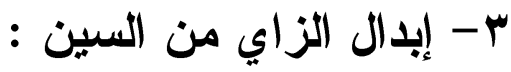

اشتركت السين و الزابي مخرجا ، ورخاوة ، وصـفيرا ،و انفـردت

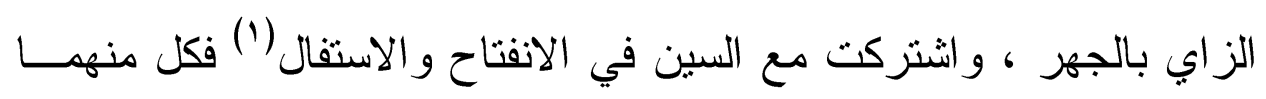

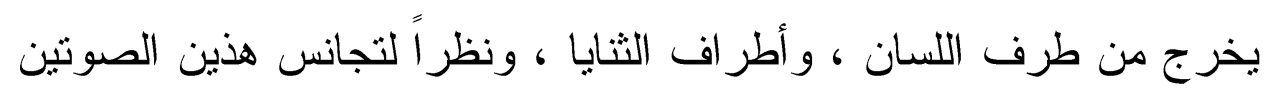

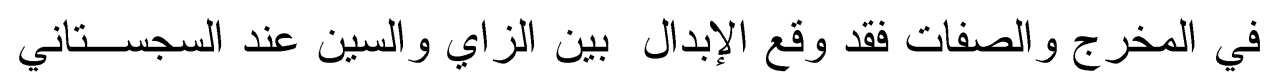

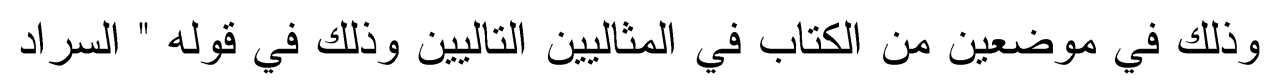

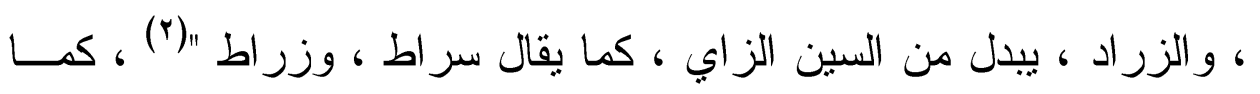

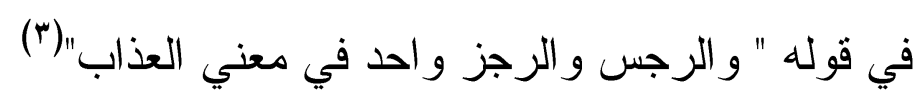
ع - إبدال الكاف من القاف :

الكاف و القاف صوتان متقاربان المخرج أما القاف فقد عدها سيبويه ومن جاء بعده من علماء العربية القدامي من أصوات أقصي اللسان فقال :

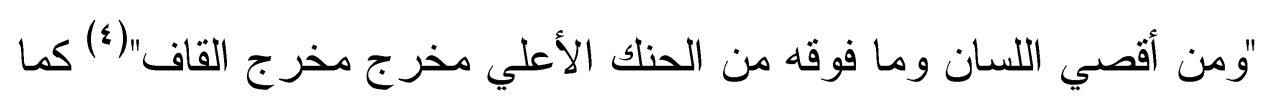

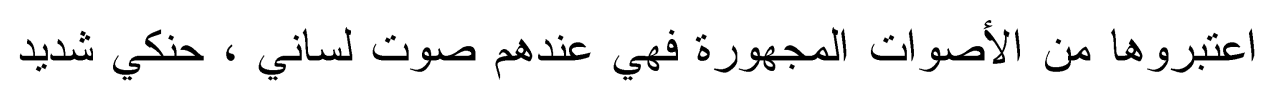

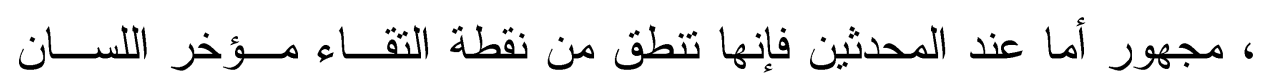

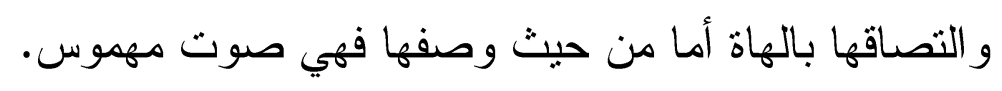

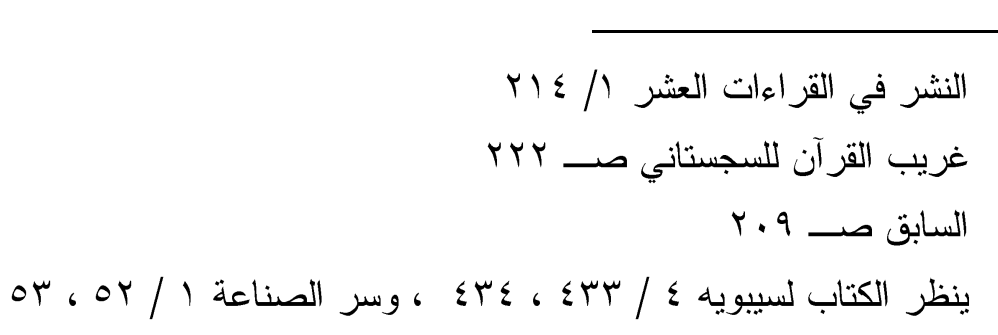


و أما الكاف فمخرجها " من أسفل من موضع القاف من اللسان قليلا

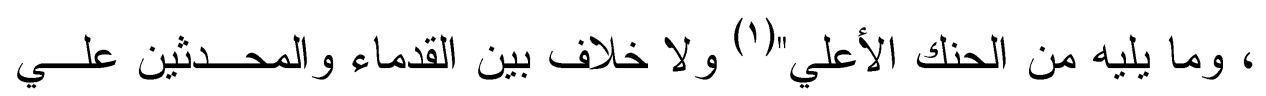

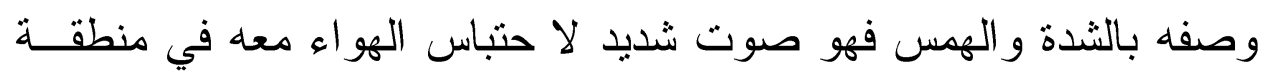
خروجه لحظة ، ومهوس لأن الونرين الصوتين لم يهتز ا معده.

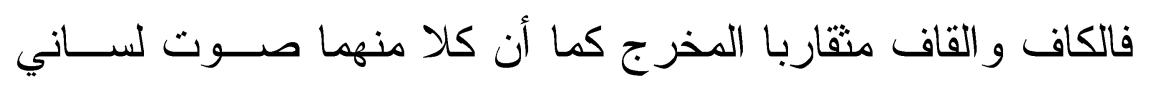

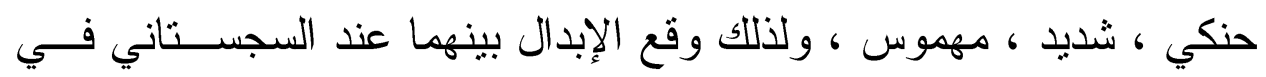

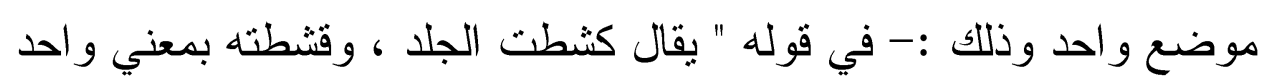
إذا انز عثه" (r)

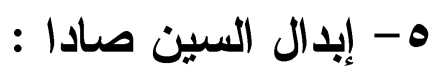

اتفقت الصاد و السين مخرجا وصفة ولا يفرق بينهما إلا أن الصــاد

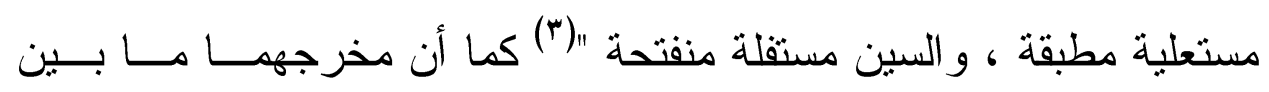

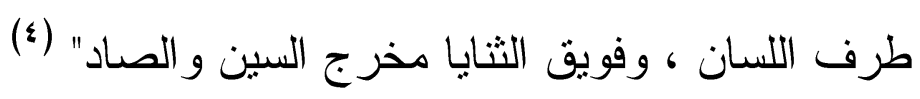
ونظر الهذه العلاقة المخرجية و الوصفية بين السين و الصاد فقد وقع

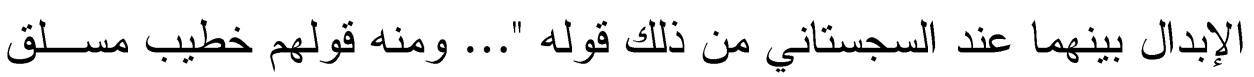

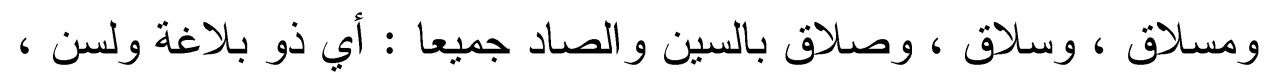

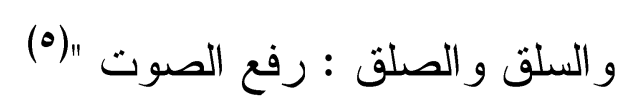

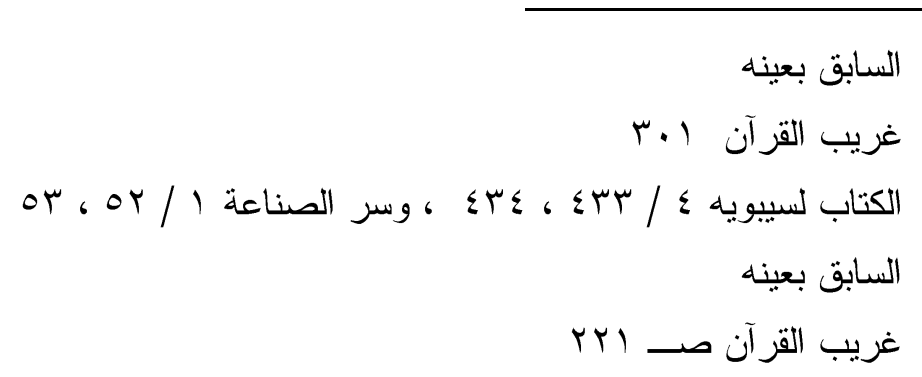


צ- إبدال السين من التاء :

اتفقت السين و التاء مخرجا وصفة حيث تخرج السين مما بين طرف

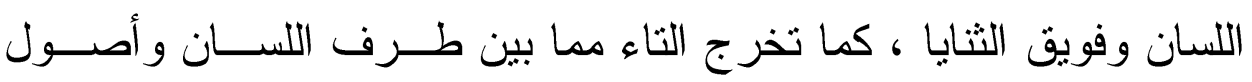

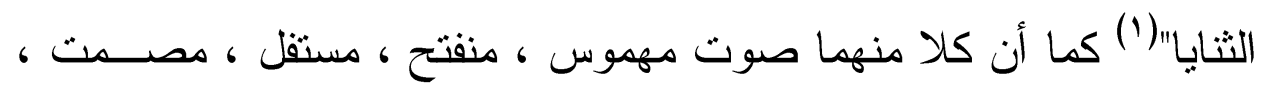

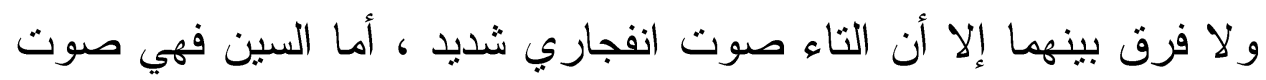

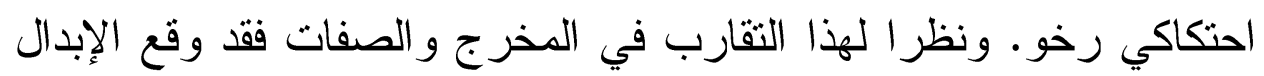

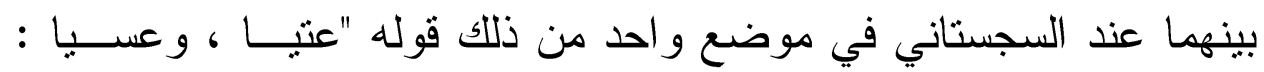

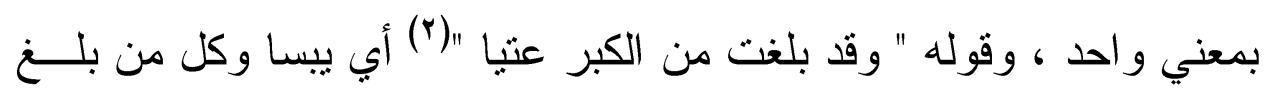

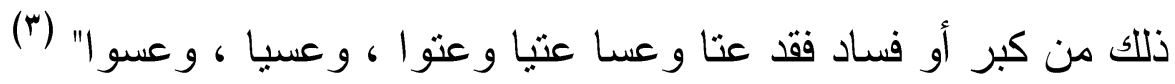

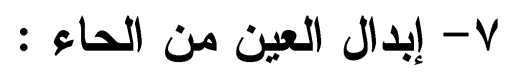

اتفقت العين مع الحاء في المخرج وفي كثير من الصفات : أما من

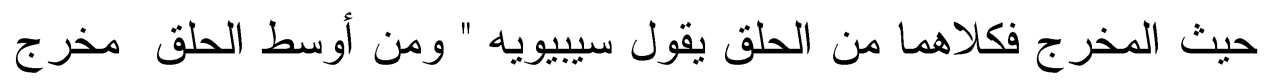

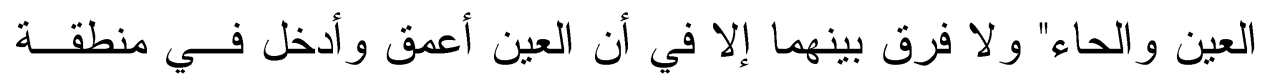

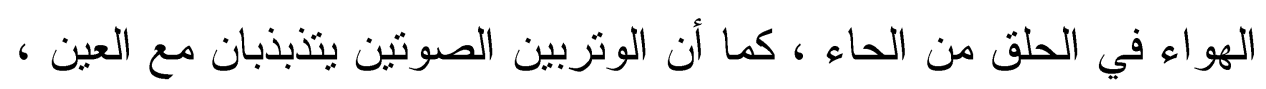

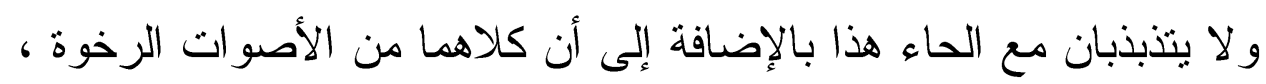

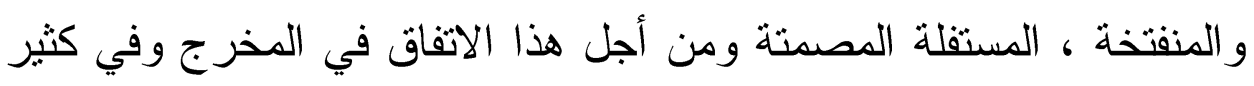

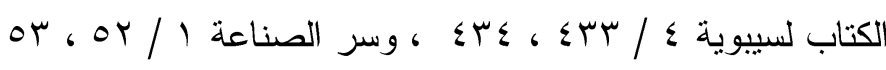

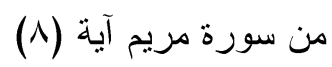

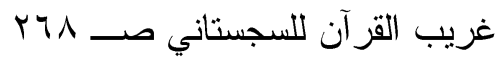


من الصفات : ساغ الإبدال بينهما عند السجستاني من ذلك قوله في موضع و احد " و الضبح و الضبع ايضا ضرب من العدو" (1)

1- إبدال الباء من الميم :

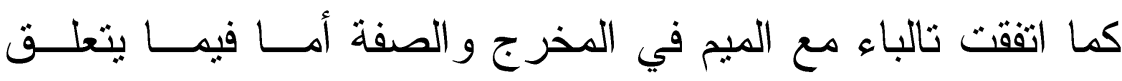
بالمخرج فإن مخرجها " مما بين الثفتين "(r) فهما من الحروف الثفوية ، و أما اتفاقهما في الصفات فإن كلا منهما من الأصوات المجهورة ، المستقلة

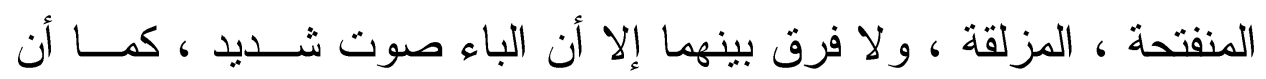
مجرى النفس معها من الفم ، أمام مجري النفس مع الميم فمــن الأنــف ،

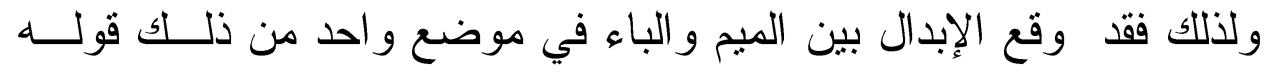

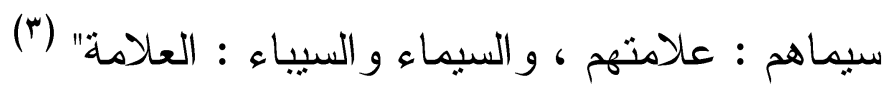
إذن نستتتج من ذلك أن الإمام السجستاني كان يري أنه لكـي بتحقــق الإبدال فلابد أن يكون هناك تقاربا بين المبدل والمبدل منه وقد صــرح بهــذه العلاقة الصونية في أكثر من موضع، أما ما لم بتحقق فيه ذلك فإنه بحمل علـي

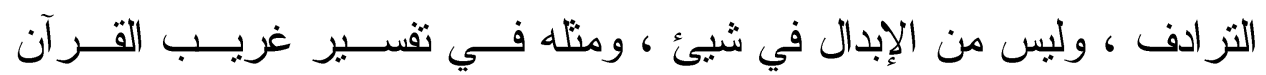

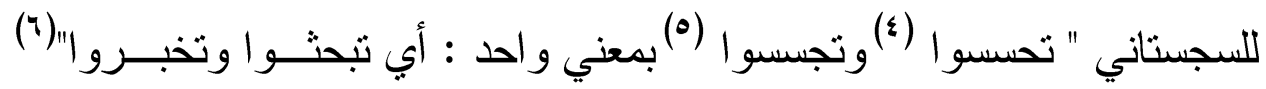
وذلك لنباعد الجيم و الحاء فهما مختلفتان في المخرج و الصفة فالجيم شـحرية ،

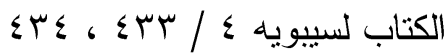

$$
\begin{aligned}
& \text { السابق بعينه }
\end{aligned}
$$

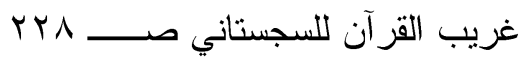

$$
\begin{aligned}
& \text { من سورة يوسف آية آية }
\end{aligned}
$$

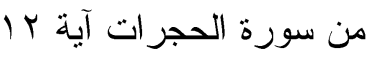

$$
\begin{aligned}
& \text { تفسير غريب القرآن للسجستاني صــ } 9 \text { ـ }
\end{aligned}
$$


مجهورة ، شديدة و الحاء حلقية مهوسة رخوة "( ) ومما يدعم ذلك وبقوبة قــول الاكتور أنبس " يؤكد لنا بعض الرواة أنه قرى " وحاسو ا خلال الديار "(r) بالحـــاء ، و لا نستطيع أن نتصور الصلة الصوتية بين الجيم و الحاء فإذا صحت الروايــة

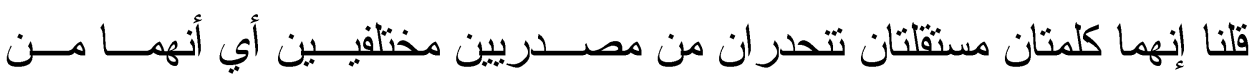

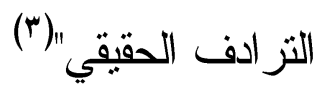

\section{ثانيا : الإبدال بين الصوائت القصيرة بعضها من بعض :}

المقصود بالإبدال بين الصوائت القصيرة الحركات الــناتلث : الفتحـــة و الكسرة و الضمة ، وقد عد القدماء "الأصوات الصائنة" ابعاض حــروف المــــ و اللين فهذا ابن جني يقول " اعلم أن الحركات أبعاض حروف المــد و اللـين ، الـين و هي الألف و الياء و الو او فكما أن هذه الحروف ثناثنة فكذلك الحركــات ثــلاث و هي الفتحة و الكسرة والضمة فالفتحة بعض الألف و الكسرة بعض الباء و الضمة بعض الواو وقد كان متقدموا النحويين بسمون الفتحة الألف الصغيرة و الكسـرة الياء الصغيرة والضمة الواو الصغيرة (๕)، كما بذكر ســر تشــية الحركــات القصيرة بهذا الاسم فيقول " و إنما سميت هذه الأصوات الناقصة حركات لأنهـــا تقلق الحرف الذبي تقتزن به وتجنذبه نحو الحروف التي هي أبعاضــــها فالقتحــــة تجنذب الحرف نحو الألف ، و الكسرة تجنذبه نحو الباء و الضمة تجذبيــه نحـــو

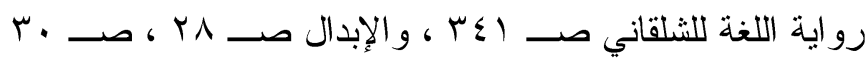

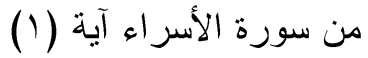

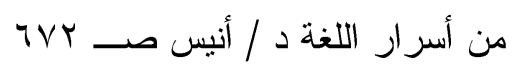

سر صناعة الإعراب / r / تحقيق أحمد / المكتبة التوفيقية. 
الواو، و لا بيلغ الناطق بها مدي الحروف التي هي أبعاضها، فإن بلغ بها مدادها تكملت الحركات حروفا أعني ألفا، وياء ، وو واوا"(1)

كما برهن ابن جني علي أن الحركات أبعاض حروف المد و اللـين فقال "ويلك علي أن الحركات أبعاض لهذه الحروف أنك مني أثبعت و احدة منهن حدث بعدها الحرف الذي هي بعضهه ، وذلك نحو فتحة عـين عمــر فإنك إن أثبعتها حدثت بعدها ألف فقلت "عامر" وكذلك كسرة عين(عنـب) إن أثبعتها نشأت بعدها ياء ساكنة ، وذلك فوللك (عينب) وكـذذلك ضــمة عين (عمر) لو أشبعتها لأنشأت بعدها واوا ساكنة ، وذللك قولــك (عــورر) فلو لا أن الحركات أبعاض لهذه الحروف و أوائل لها لما نشأت عنها ، و لا

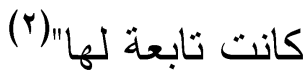

يتضح من هذا أن أصوات اللين إما طزيلة و إما قصيرة فالطويلـــة تتمثل في الألف و الو او و الياء ، و القصبرة هي الفتحة و الضـــمة و الكســرة فألف المد ما هي إلا فتحة طويلة ، وو او المد ما هي إلا ضـــمة طويلـــة ، وياء المد ما هي إلا كسرة طويلة ، وقد سماها علمـــاء اللغـــة المحــدثن

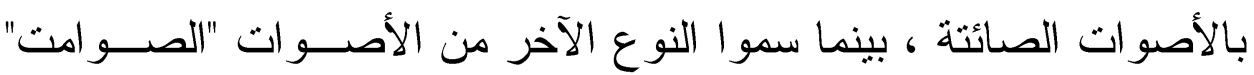
في مقابل تسمية علماء اللغة القدامي لها " السو اكن" و الصوامت أو السو اكن تشعل جميع حروف الإبجدية بما في ذلك همزة القطــع ، و الــــواو و البـــاء غير المديتين. 
وقد قرر العلماء أن الصوات الصائتة "الحركات" هي ثنلك الأصوات

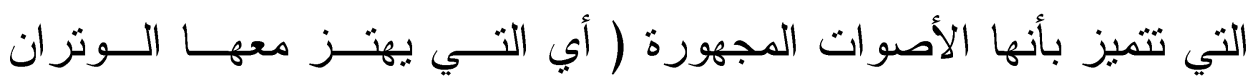

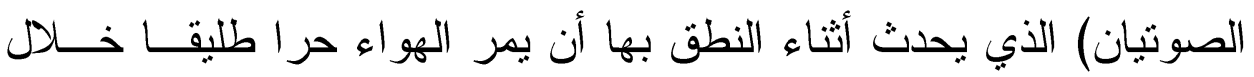

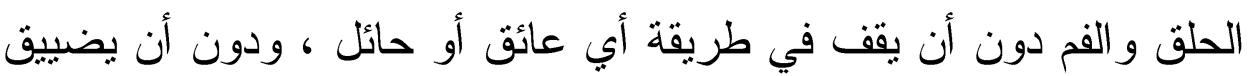

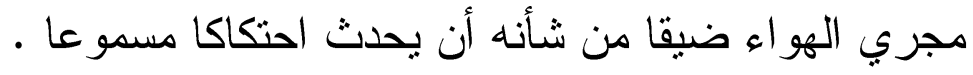

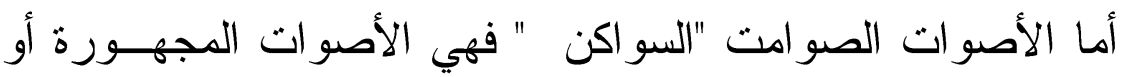

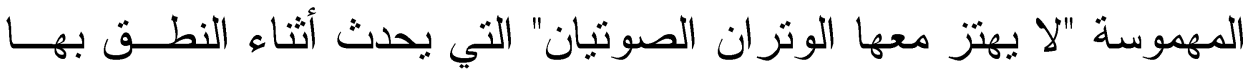

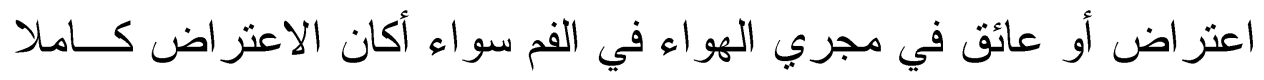

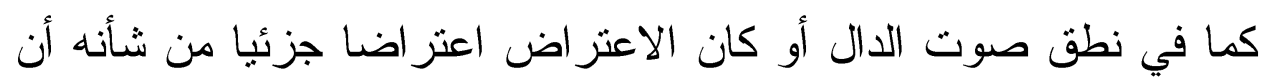

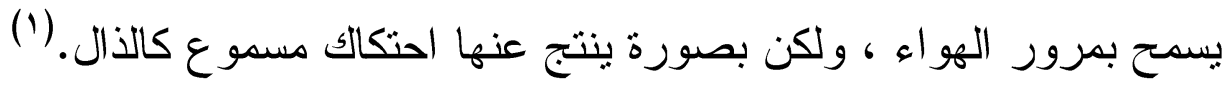
المغني الأساسي للكلمة منوط بالأصوات الساكنة. للأصوات الساكنة (ونعني بها ما عدا الأصوات اللينة) في اللغــات

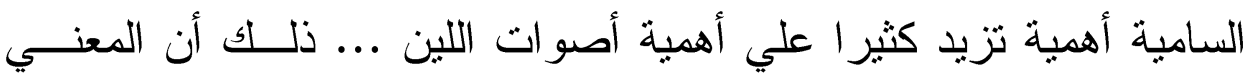
الأساسي للكلمة يشار إليه غالبا بالأصوات الساكنة ، أما الأصوات اتلبه اللينة فلا نعدو وظيفتها في الغالب تحديد هذا المعني العام وتوجيه وجهات خاصة ف " ق ت ل" يدل علي المعني العام للقتل ، وقتل يدل علي وقوع القتــلـ فــي زمن مضي من واحد غائب ، وقتل بدل علي قتل حدث في زمن مضـي ،

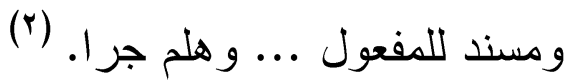

$$
\text { ينظر علم الأصوات د/ كمال بشر صـ الــ } 101 \text { بتصرف }
$$

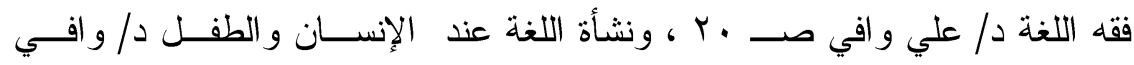

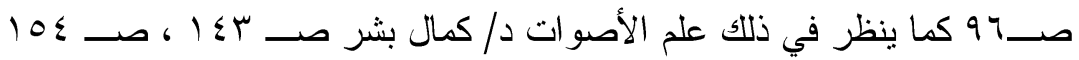


هذا وقد أطلق علماء اللغة علي اللفظ الواحد الذي تختلف حركة فائة

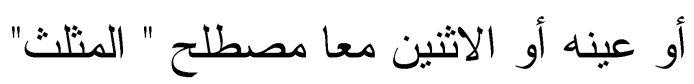

و التنليث - بمفهومه النهائي - بعني تحريك أحد حروف الكلمة غيـر

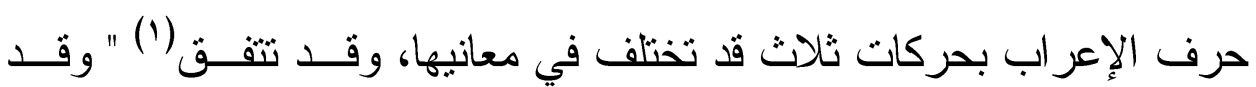
درست كتاب غريب القر آن للسجستاني تحت مفهوم الإبدال بـين الصــوائت القصيرة ، فمع النماذج التي جمعتها من هذا الكتاب ، وأجريت عليها الدراسة.

\section{أولا : الإبدال بين الفتحة والضمة والكسرة باتحاد المعني :}

الربوة : الربوة : الربوة يقول السجستاني "ربــوة ذات قـرار

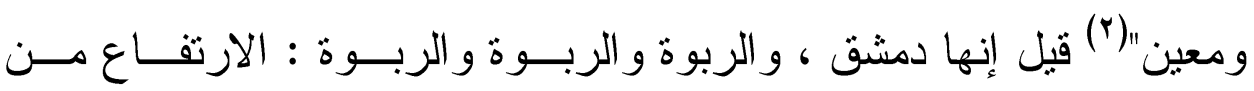
الأرض"(") وقد نبه صاحب اللسان إلى هذا الاتحاد في المعني فقال " الربو و الربوة و الربوة ، و الربوة و الرباوة ، و الرباوة ، و الربــاوة ، و الر ابيــة ،

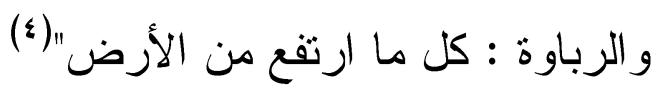

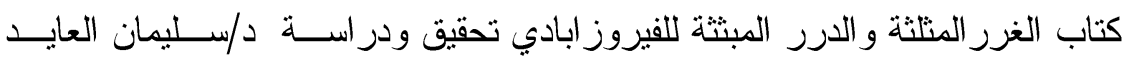

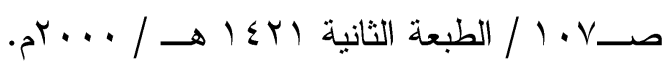

$$
\begin{aligned}
& \text { من سورة المؤمنين آية (.0) }
\end{aligned}
$$

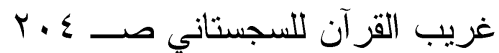

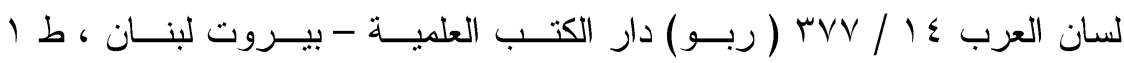

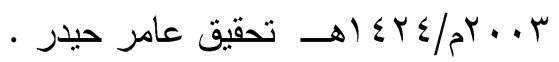




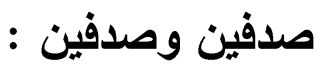

صدفين (') وصدفين : ناحيتي الجبل ، وقوله تعالي " ســاوي بـين

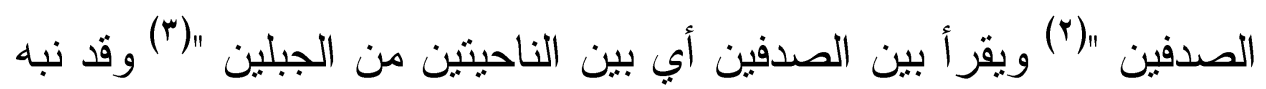
صاحب اللسان إلى هذا الاتحاد في المعني إلا أنه فسر الصدفين بـالجبلين

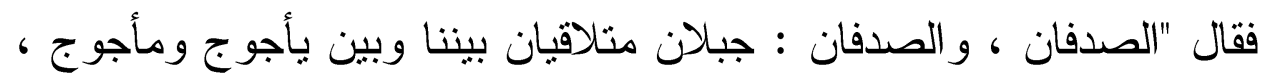
وفي التنزيل العزيز " حتى إذا ساوي بين الصـــفين" قــري الصــدفين ، و الصدفين و الصدفين " (๕) الصنيز

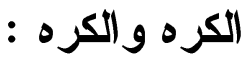

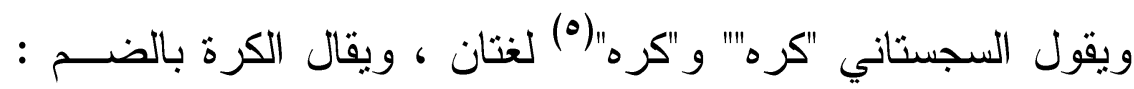

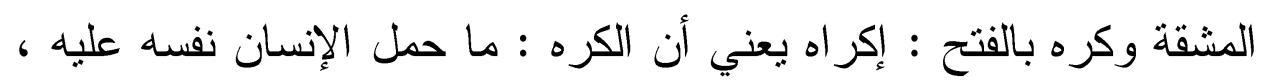

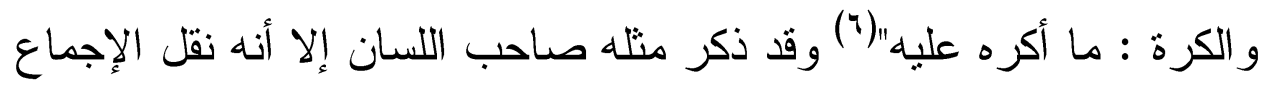

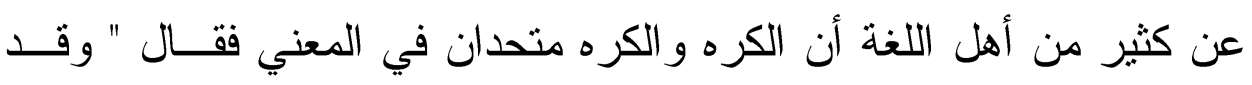

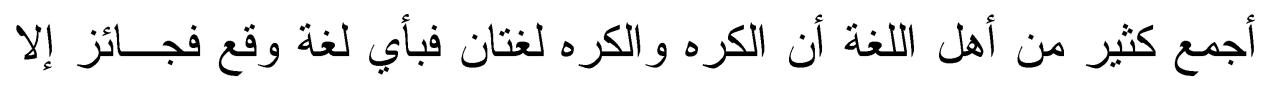

هي قراءة عاصم وابن محيصن وابي رجاء وأبي عبدالرحمن وشعبة ، معجم القــراءات

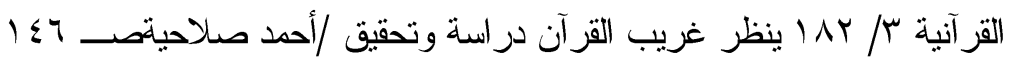

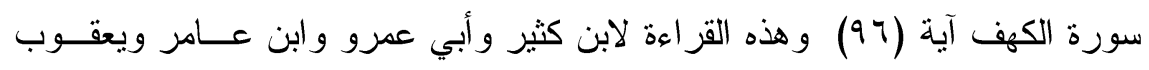

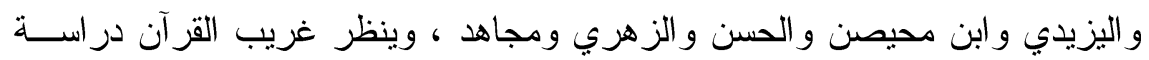

$$
\begin{aligned}
& \text { وتحقيق أحمد صلاحية. }
\end{aligned}
$$

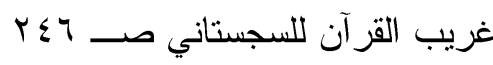

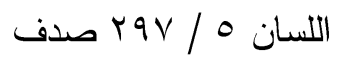

$$
\begin{aligned}
& \text { من سورة البقرة آية (YT/T) } \\
& \text { غريب القرآن صـ ... }
\end{aligned}
$$




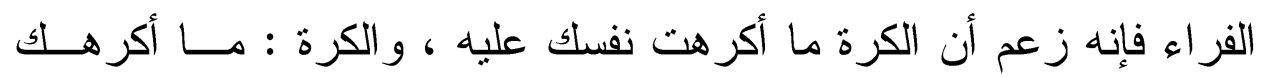
غيرك عليه" (1)

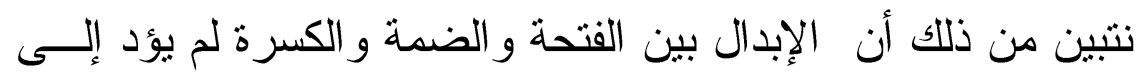

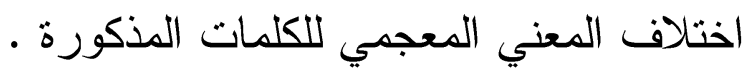
الإبدال بين الفتحة والضمة باختلاف المعني :

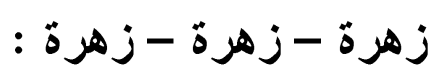

يقول السجستاني "زهرة الحياة الدنيا"(†) ابي زينتها ، و الزهرة : برة : بقتح الزاب و الهاء : نور النبات ، و الزهرة : بضم الز ابي واسكان الهاء وفتحها : النجم "(") ، وقد نبه إلى هذا الاختلاف في المعني صاحب اللســان فقــال

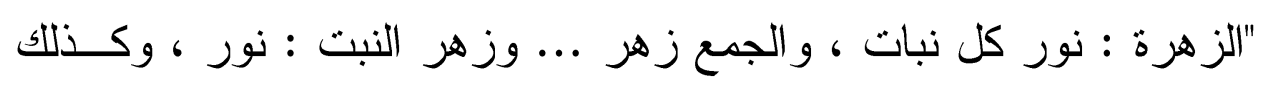

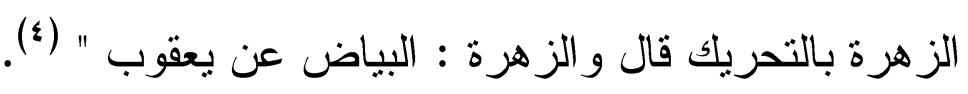

$$
\text { ركوب - ركوب : }
$$

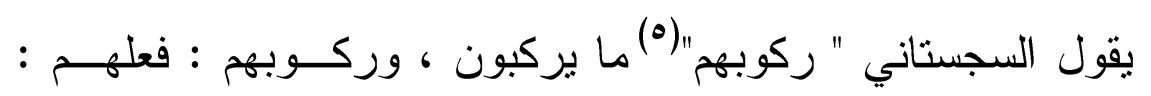

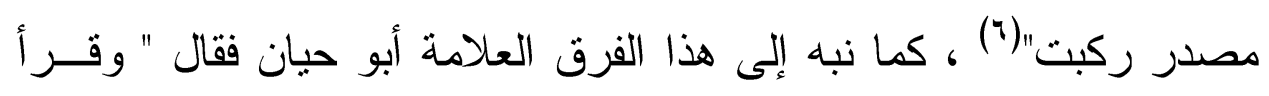

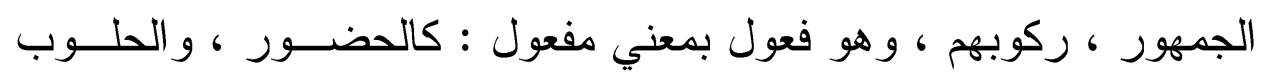

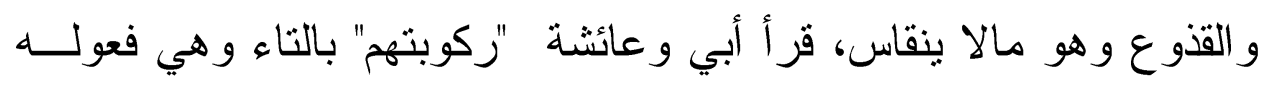

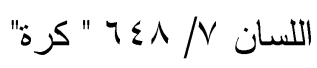

$$
\begin{aligned}
& \text { من سورة طه آيه ( آساب) }
\end{aligned}
$$

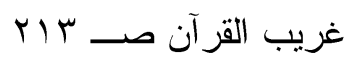

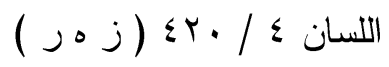

$$
\begin{aligned}
& \text { من سورة يس آيه } \\
& \text { غريب القرآن صـ بـ باب }
\end{aligned}
$$




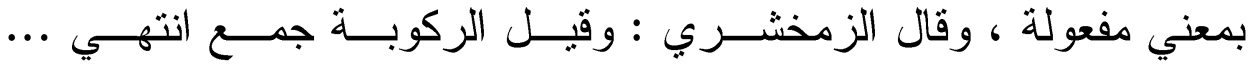
وقر ألحسن و أبو هيثم و الأعمش "ركبهم" بضم الر اء وبغير ناء وهو مصدر

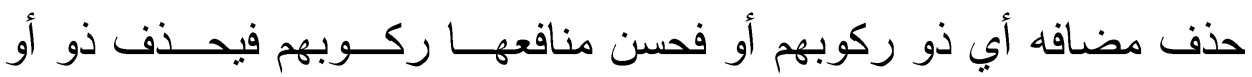
يحذف منافع" (1)

\section{ضعف وضعف :}

ويقول السجستاني (ضعف وضعف(r) لغتان ، وقيل : ضعف بالضم ما كان من الخلق ، وضعف : ما كان يتتقل) (ّ) ومما بــدعم السجســناني ويؤيده ما نقله صاحب الللسان من أن " الضعف و الضعف : خلاف القوة ، وقيل : الضعف باضم في الجسد ، و الضعف بالفتح في الــر أي و العقـلـل ،

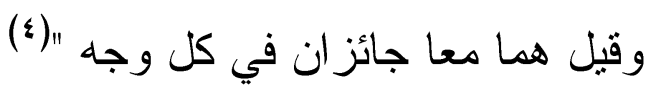
فواق وفواق :

ويقول السجستاني "فواق"(ه) راحة وإفاقة كإفاقة العليل مــن علتــه وفواق بضم الفاء : قدر ما بين الحلبتين ، ويقال "فو اق" و " فو اق" بمعنـي

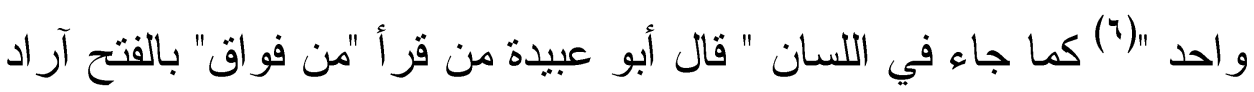

البحر المحيط لأبي حيان V / اسب من سورة الروم آيه (ع م) غريب القران صـ ro. اللسان / / ب. ( ضعف) من سورة (ص) آية (10)

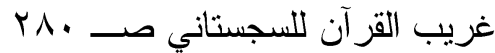


ما لها من إفاقة ولا راحة ، ذهب بها إلى إفاقة المريض ، ومسـن ضــمنها

جعلها من فو اق الناقة وهو ما بين الحلبتين : بريد ما لها من انتظار "(1) : قرح وقرح

ويقول السجستاني "قرح"(ז) وقرح : جر اح ، وقيل القرح بفتح القاف

الجراح ، و القرح : بضم القاف : ألم الجراح "(ז) كما جـــاء فــي اللســان "قال الفراء في قوله عز وجل " إن يمسسكم قرح" وقرح قال وأكثر القراء علي فتح القاف ، وكأن القرح الم الجراح ، وكأن القرح الجر اح بأعيانهــا

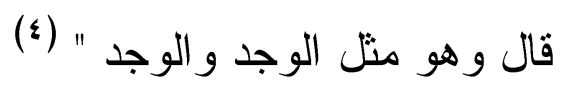

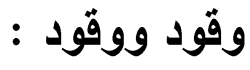

كما يقول " وقود"(ه) ما توقد به النار ، وبالضم : مصــدر "(؟) كمـــا جاء في اللسان الوقود : الحطب... قال تعالي "و أولئك هم وقود النار" الوقد

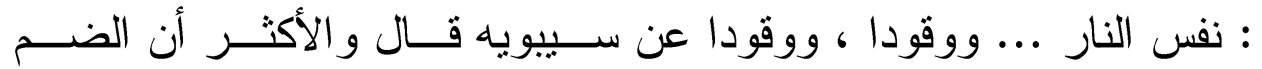

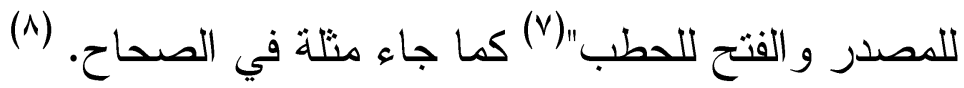

$$
\begin{aligned}
& \text { اللسان V/ / / } 19 \text { ( فوق) }
\end{aligned}
$$

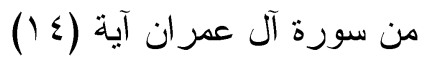

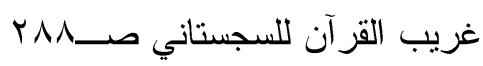

$$
\begin{aligned}
& \text { اللسان ( قرح) } \\
& \text { من سورة آل عمران آيه (• (1) } \\
& \text { غريب القرآن صـ ^ی } \\
& \text { اللسان (وقد) } \\
& \text { الصحاح ( وقد) }
\end{aligned}
$$




\section{الإبدال بين الضمة والفتحة باتحاد المعني :}

\section{نصب ونصب ونصب :}

يقول السجستاني "نصب ونصب ونصب" بمعني و احد وهو حجر أو

صنم منصوب يذبحون عنده"(1) كما بنه القاسمي إلى هذا الاتحاد في المعني

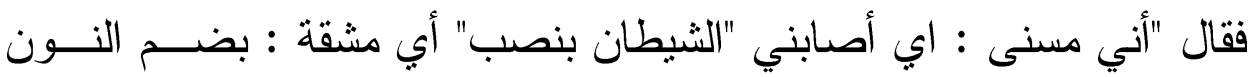
وفتحها مع سكون الصاد ، وبفتحها وضمهها "(r) كما جاء في اللسان (ّ) أن النصب و النصب و النصب : الداء و البلاء و الثر ، وفي التنزيــل العزيـز

"مسني الثيطان بنصب و عذاب" (\& و و

دولة ودولة :

كما يقول " دولة بين الأغنياء منكم"(ه) يقال دولة ودولة لغتان..."(") كما نبه ابن منظور إلى هذا الاتحاد في المعني فقال" الدولة و الدولة : العقبة في المال و الحرب سو اء بسو اء..."(v)

نلحظ من ذلك أن الإبدال بين الضم و الفتح لم بــؤد إلــى اخــتلاف

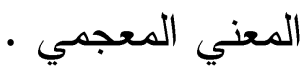

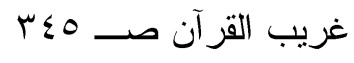

تفسير القاسمي " محاسن التأويل " محمد جمال القاسمي ^ / ب ب ب ضبط محمد باسل

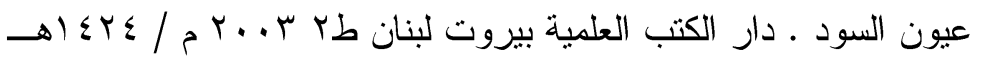

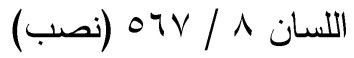

$$
\begin{aligned}
& \text { من سورة (ص) آيه (1) آنهان (1) } \\
& \text { من سورة الحشر آيه (V) } \\
& \text { غريب القرآن صــ } 197 \\
& \text { اللسان ب / • 0؛ (دول) }
\end{aligned}
$$


الإبدال بين الضم والفتح باختلاف المعني : حوبا وحوبا باختلاف المعني :

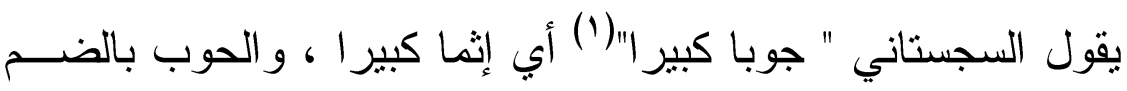

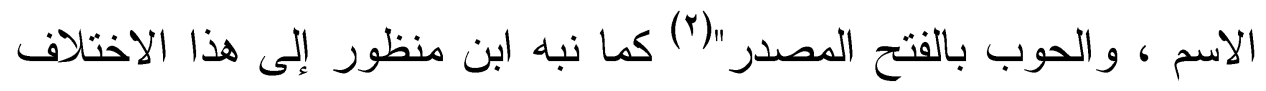

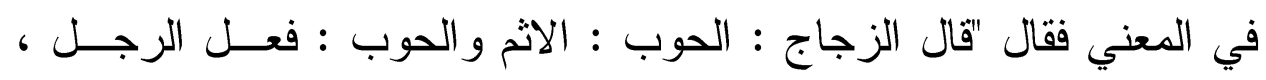

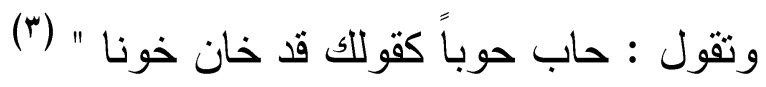

نلحظ أن الإبدال بين الضم والفتح أدي إلى اختلاف المعني المجمي

\section{الإبدال بين الضم والكسر باتحاد المعني :}

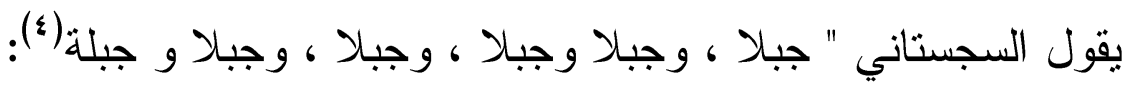

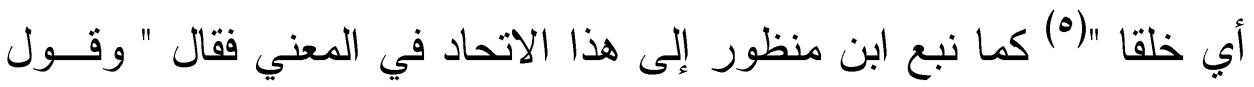

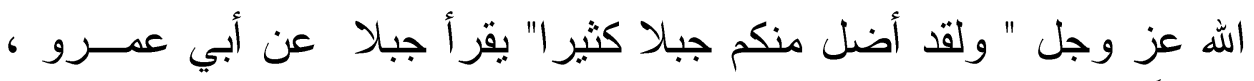

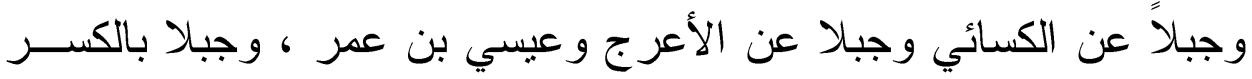

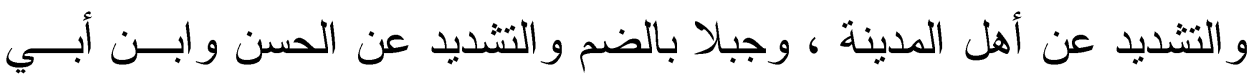

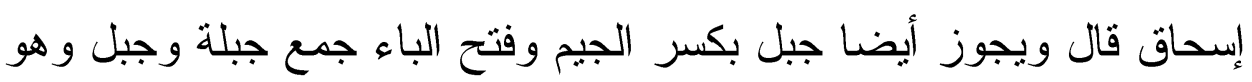

في جميع هذه الوجوة خلق كثير "(أ)

و هكذا نجد أن الإبدال تبين الضم والكسر لم يؤد إلى اختلاف المعني الدعجي.

من سورة البقرة آية (INV)

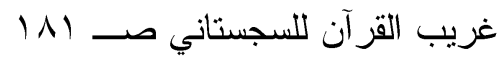

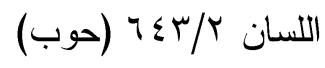

سورة يس آية (rآ)

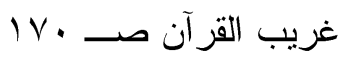

اللسان r/r r (جبل) 
الإبدال بين الفتح والكسر باتحاد المعني : الحج والحج : (ل)

يقول السجسناني " الحج و الحج لغتان ، ويقال الحــج : المصــدر، و الحج الاسم "(1) كما نبه ابن منظور إلى هذا الاتحاد في المعني فقال "الحج و الحج لبس عند الكسائي بينهما فرقان"(r)

كذلك لم يؤد الإبدال بين الفتح و الكسر إلى اختلاف المعني المعجمي الإبدال بين الفتح والكسر باختلاف المعني :

يقول السجستاني "و لايتهم"(َ) الولاية : بفــتح الـــواو : النصــرة ،

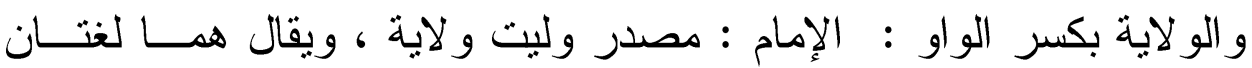
بمنزلة الدلالة و الدلالة "(๕)، وقد نبه إلى هذا الاختلاف فــي المعنــي ابـن فئن منظور فقال "ابن السكيت : الولاية بالكسر السلطان ، و الولاية و الولايـــة : النصرة يقال هم علي ولاية : أبي مجتمعون في النصرة ، وقال ســيبويه : الولاية بالفتح : المصدر ، و الولاية بالكسر الاسم مثل الإمارة و النفاية لأنه

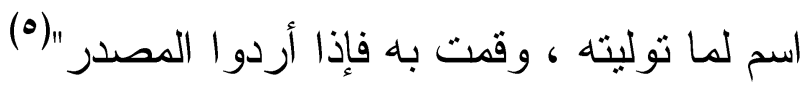
نتبين من هذا أن الإبدال بين الفتح والكسر قد أدي إلــى اخـتلاف

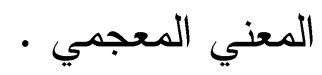

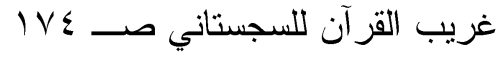

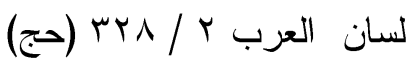

$$
\begin{aligned}
& \text { من سورة الأنفال آية (VY) } \\
& \text { غريب القرآن صـ 9 ؟ } \\
& \text { اللسان 0/9 . ع "ولي" صري" }
\end{aligned}
$$




\section{الإبدال بين الكسر والضم باختلاف المعني :}

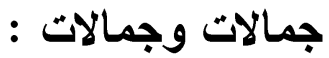

يقول السجستاني " جمالات صفر "( ) إبل سود جمــع جمالــه، وواحـــ الجمالة : جمل ، وجمالات بضم الجيم : قلوس سفن البحر"(r) ومما بعضد كلام السجستاني ما نقله ابن منظور في هذا الثأن فقال "الأزهري وأما قولــهـ تعــالي "جمالات صفر" فإن الفراء قال : قر أ عبدالله و أصحابه جمالة وروي عن عمــر بن الخطاب رضي الله عنه ، أنه قرأ جمالات قال وهو أجب إلى لأن الجمـال أكثر من الجمالة في كلام العرب ... فإذا جمالات فواحدها جمال منل ما قـالو البه رجال ورجالات، وبيوت وبيوتات ، وقد يجوز أن بكون واحد الجمالات جمالـــة

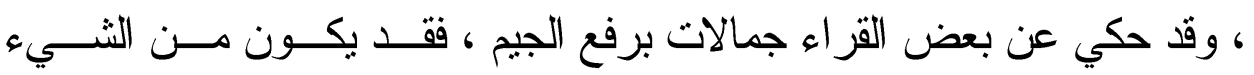

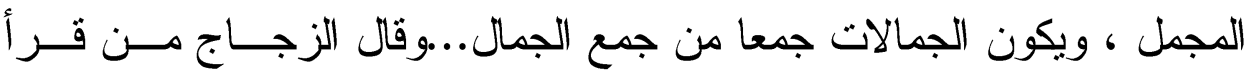
جمالات فهو جمع جمالة وهو القلس من قلوس سفن البحر "(") كبره وكبره :

يقول السجستاني " كبره"(؛) وكبره : لغنان: أي معظمه ، ويقال كبر

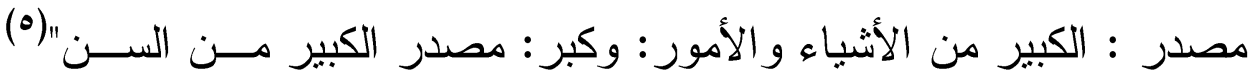
ومما يعضد كلام السجستاني ويقويه هنا أيضا ما جاء في لسان العرب حيث يقول " ابن سيده و الكبر : معظم الثيء بالكسر ، وقوله تعالي " و الذي تولي

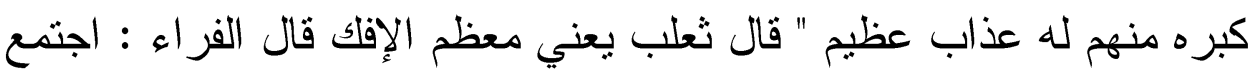

$$
\begin{aligned}
& \text { في القرآن " جمالة صفر" المرسلات آية (بrس) } \\
& \text { غريب القزآن صـ IV } \\
& \text { اللسان / T • ץ "جمل" } \\
& \text { سورة النور آية (11) } \\
& \text { غريب القرآن صــ r.r }
\end{aligned}
$$


القراء علي كسر الكاف ، وقرأها حمبد الأعرج وحده كبرهو هو وجه جيد

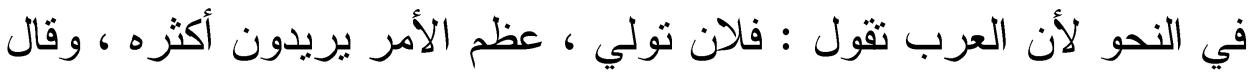

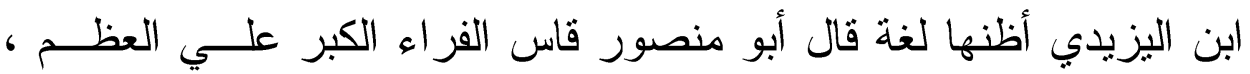

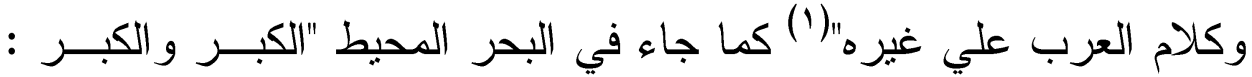
مصدر ان لكبر الثيء عظم لكن استعمال العرب بالضم ليس في السن هذا

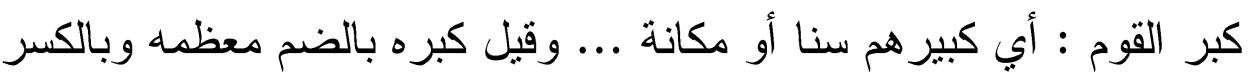

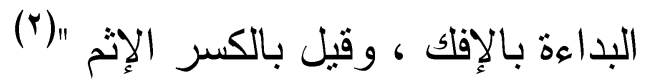

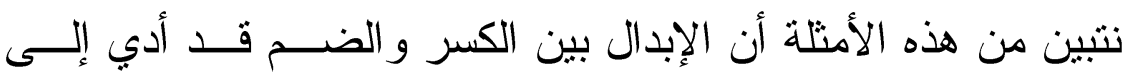

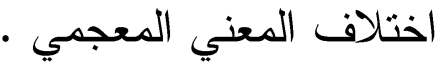
الإبدال بين الضم والكسر مع اتحاد المعني :

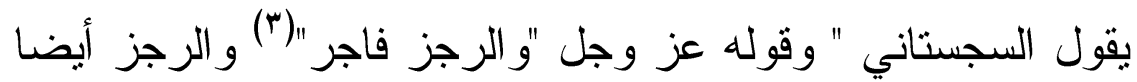

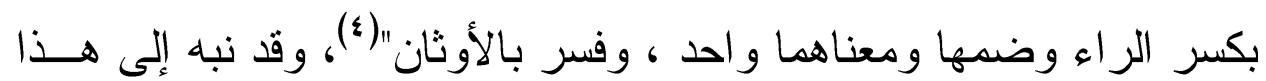

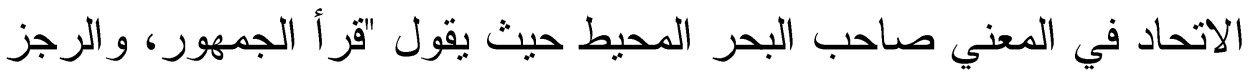
بكسر الر اء ، وهي لغة قريش و الحسن ومجاهد و والســلمي و أبـــو جعفــر

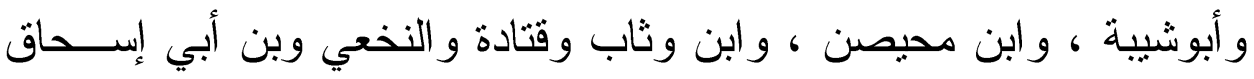

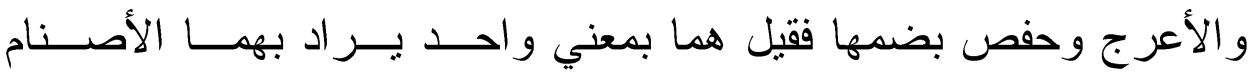

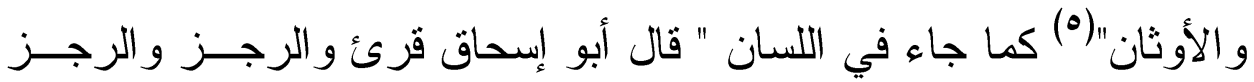

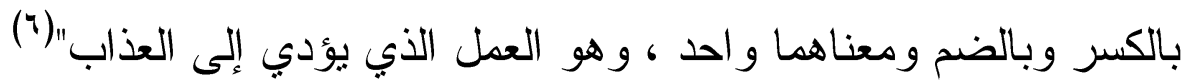

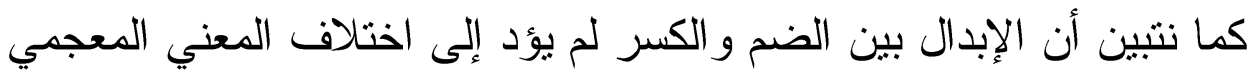

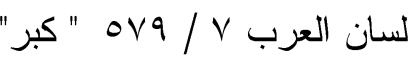

$$
\begin{aligned}
& \text { البحر المحيط } 7 \text { / r +ع } \\
& \text { من سورة المدثر آية ه }
\end{aligned}
$$

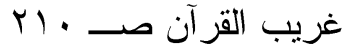

$$
\begin{aligned}
& \text { البحر المحيط ه/ ع عب }
\end{aligned}
$$

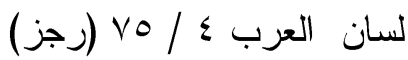


- $01 Y \varepsilon-$

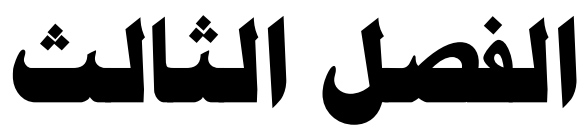

4 
تخفيف الاهمز وتحقيقه :

من الظو اهر الصوتية في " غريب القر آن" للسجستاني ظاهرة تحقيق الهمز وتخفيفه . - الهن

مع أن صوت الهمزة أصيل في اللغات السامية ، فإن الجهد العضلي الذي يتطلبه في نطقه أدي إلى ضياعه في كثــر مــن اللغـــات الســامية و اللهجات الحجازية القديمة في العربية"(1) قال ابن بعيش "اعلم أن الههــزة إنه حرف شديد مستنقل يخرج من أقصي الحلق إذ كان أدخل الحــروف فــي الحلق فاستثل النطق به ، إذ كان إخر اجه كالتهوع فلذلك الاستثقال ساغ فيه التخفيف"(r)

لذلك فقد عمدت بعض القبائل العربية إلى نخفيف النطق بــالهزز (º

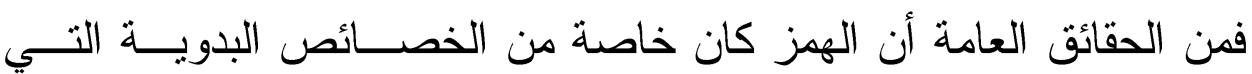

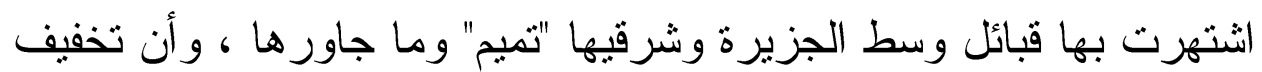
الهمز كان خاصة حضرية امتازت بها لهجة القبائل في شــمال الجزيـرة

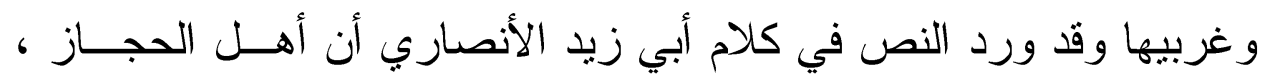
و هذيل ، و أهل مكة و المدينة لاينبرون" (ع) وقد نسب بعــ أئــــة اللغـــة

بحوث ومقالات في اللغة د / رمضان عبــدالتواب صـــ rV الطبعـة الأولــي

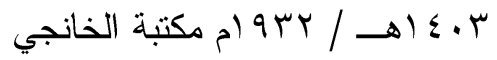

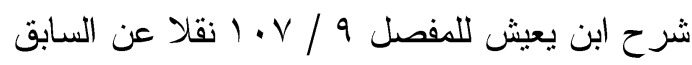

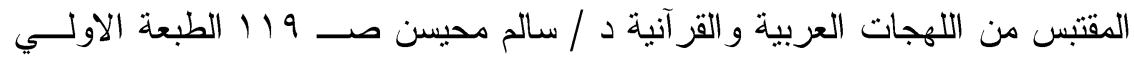

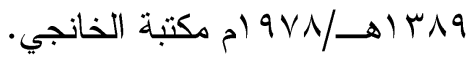

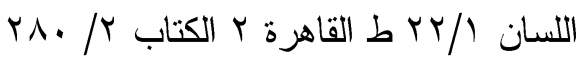


الأو ائل ظاهرة تخفيف الهمز إلي الحجازيين ، ولكن ينبغي ألا يؤخذ هــذا الحكم علي إطلاقه لاعتبارين :

أحدهما : أن الأخبار تدل علي أن بعض الحجازيين كانوا بحققون

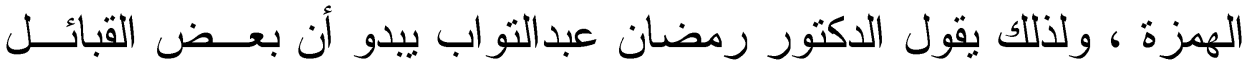

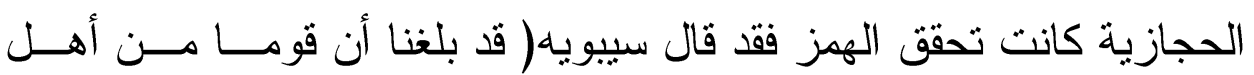

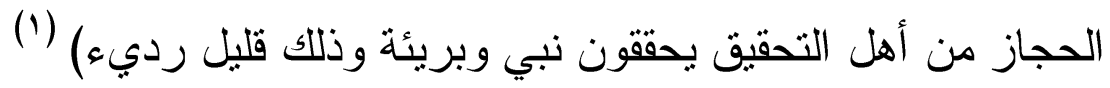
الثاني: أن تخفيف الهمز لم يكن مقصور اً علي هنطقة دون أخرى، وإنما

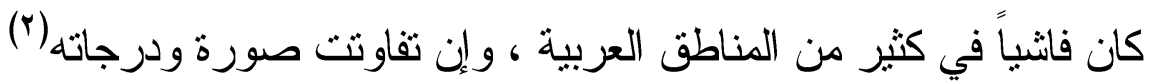
و إذا كانت القبائل البدوية التي تميل إلي السرعة في النطق ، وتشــلـك

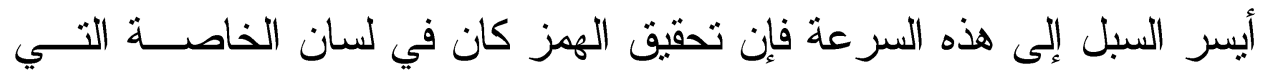
تخفف عيب هذه السرعة ، أي أن الناطق البدوي تعود النبر في موضع الهين الهمز

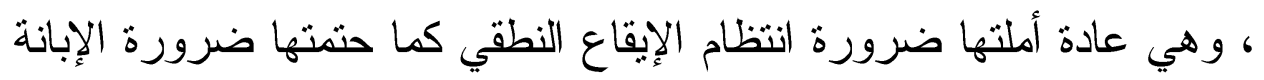

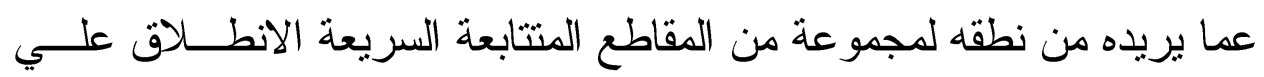

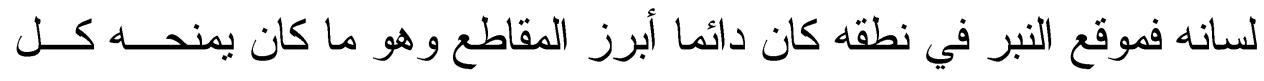

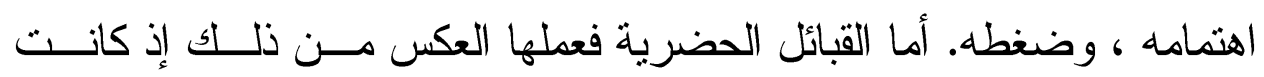

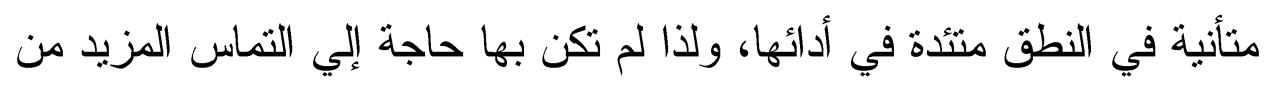

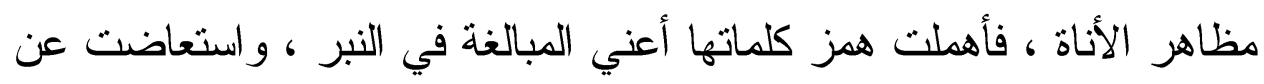

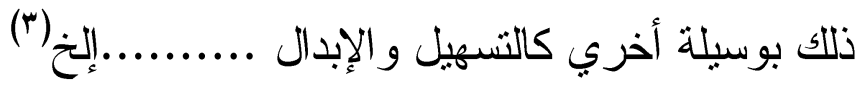

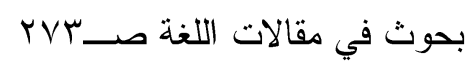

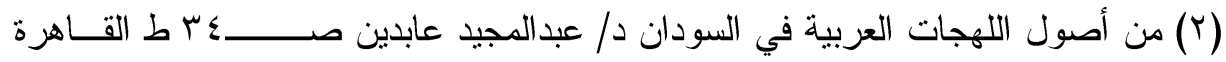

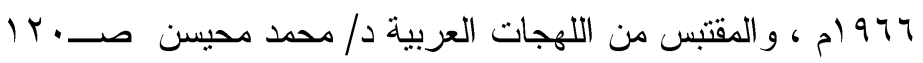

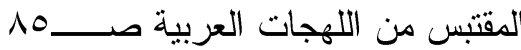




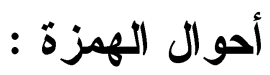

الههزة العربية لها ثلاثة أحو ال : التحقيق ، التسهيل ، التحويل .

ففي اللسان : " قال أبو زيد الأنصاري : الهمز علي ثلاثة أوجـهـ :

التحقيق ، و التخفيف ، و التحويل ، فالتحقيق منه أن تعطى الهمزة حقها من

الإشباع فإذا أردت أن تعرف إثباع الهمزة فاجعل العــين فـي موضـــها كقولك من الخبء قد خبأت للك بوزن خبعت .... قال و التخفيف من الهمز ، إنما سموه تخفيفاً لأنه لم يعط حقه من الإعر اب ، و الإشباع ، وهو مشرب

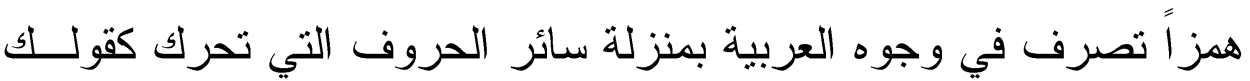

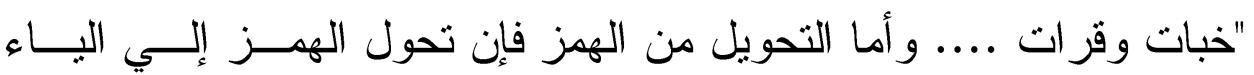

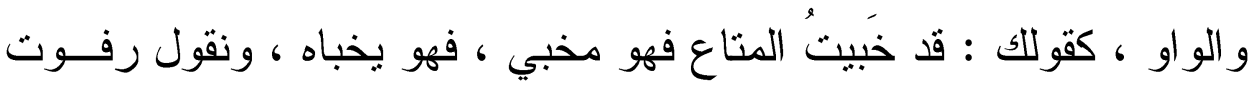
النوب رفوا ، فحولت الهززة و او كما نزى" (1) تخفيف الهمز وتحقيقه في غريب القرآن للسجستانى

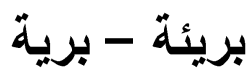

يقول السجستاني " بَرَيةً"(r) خلق مأخوذ من برأ الله الخلق : أي خلقهم

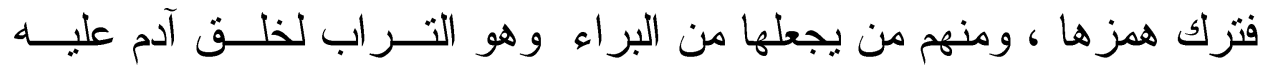

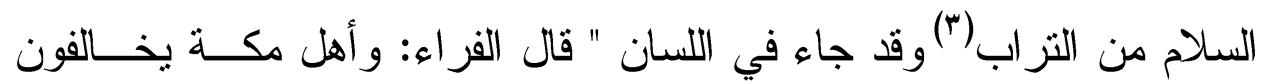
غيرهم من العرب يهزون البريئة والنبيء والذريئة ؟! وقال اللحيانى أجمعت

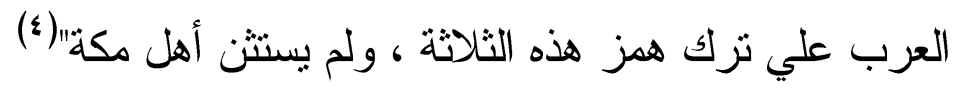

$$
\text { (1) اللسان حرف الهمزة / (1) باب الهمزة }
$$

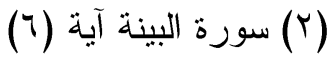

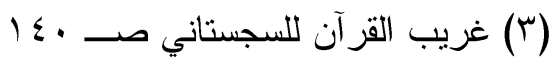

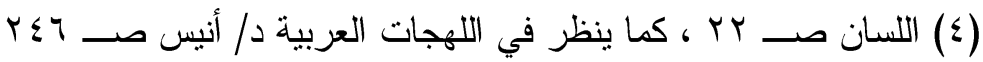




\section{حمئة - حامية}

ويقول أيضـا " حَئئة "(1) مهموزة ذات حمأة حمية ، وحاميــة بـلا

همزة : أب حارة(؟) ومما يقويه أن ابن منظور يقول في اللسان وعين حمئة

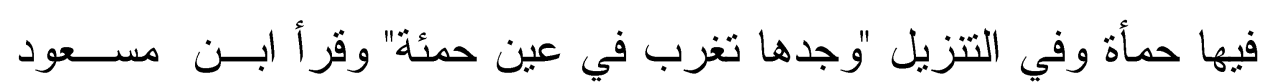

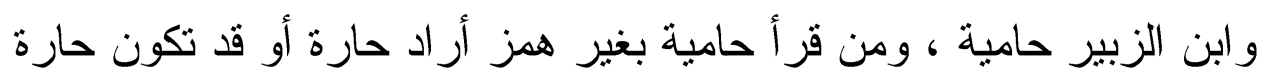

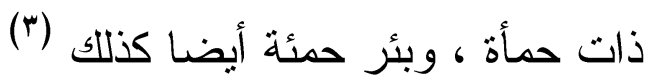

دري-دريء

ويقول السجستانى " دري : (4) مضئ منسوب إلى الدر في ضـــيائه

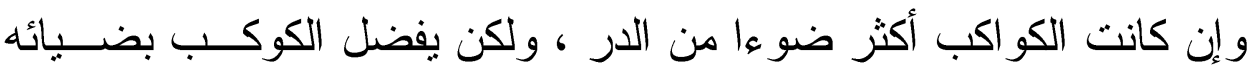

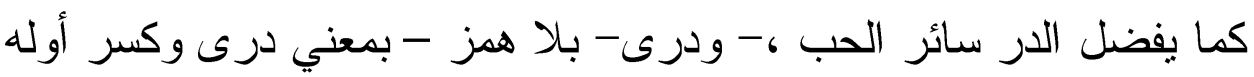

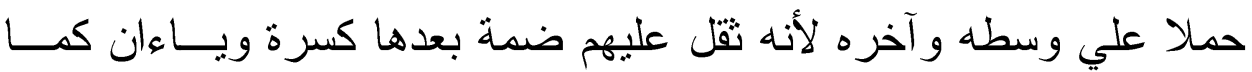

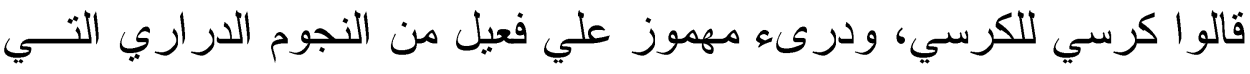

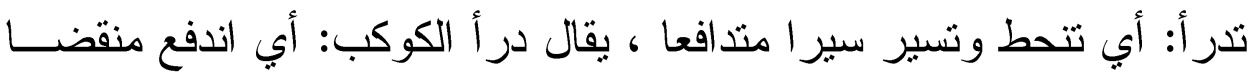

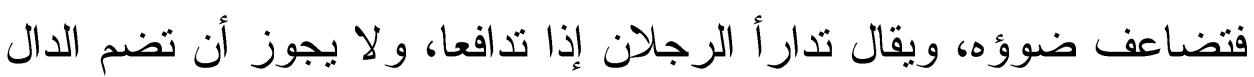

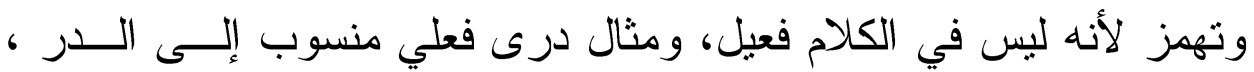

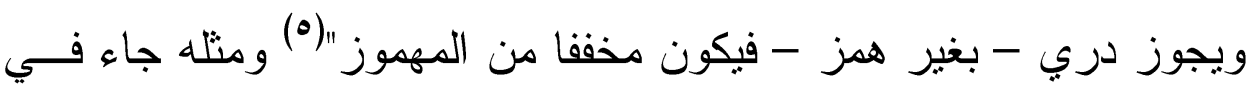

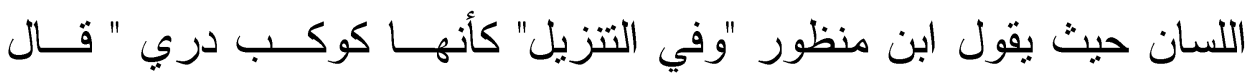

(1) من سورة الكهف آية (1) (1)

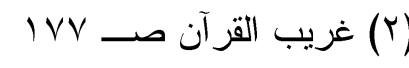

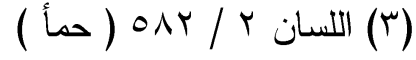

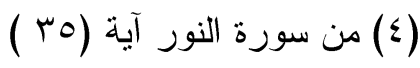

(0) غريب القرآن صـ 190 
أبو إسحاق : دن قر أه بغير همز نسبه إلى الدر في صفائه وحسنه وبياضه ، وقرئت " دري"(1) بالكسر ، قال الفراء : ومن العرب من يقول دري ينسبه إلى الدر ، كما فالو ا بحر لجي وسخرى وسخرى ، وقرى " درىع "بــالهمز

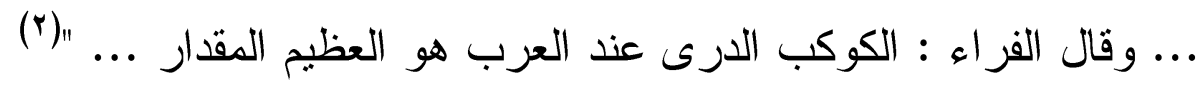

\section{السؤرة - السورة : - السور}

ويقول " سورة"(") غبر مهموزة : منزلة نزتفع إلى منزلــة أخــري

كسورة البناء سؤرة - مهوزة - قطعة من القرآن علي حدة من قــولهم : أسأرت من كذا : أي أبقيت و أفضلت منه فضله "(\{) كما جاء في اللســان " قال ابو الهيثم : السورة من سور القرآن عندنا قطعة مــن القـر آن ســق وحدانها جمعها كما أن الغرفة سابقة للغرف ، و أنزل الله عز وجل القــرآن علي نبيه صلي الله عليه وسلم شيئا بعد شيء وجعله مفصلا وبين كل سورة

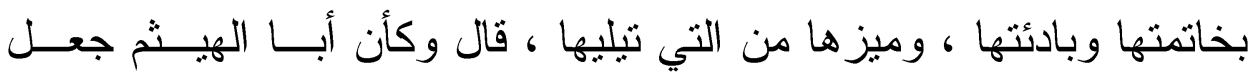

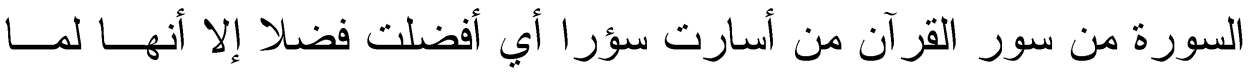
كثرت في الكلام ، وفي القرآن نزك فيها الههز كما نزك في الملك "(ه)

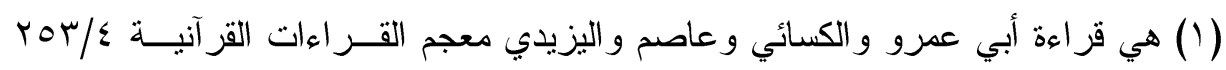

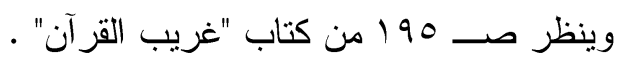

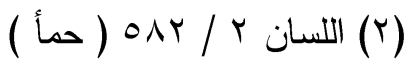

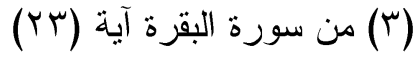

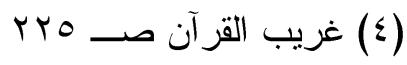

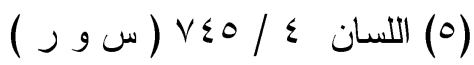




\section{التناؤش - التناوش}

يقول السجستاني في " تتاوش"(1) تتــاول : يهـــز و لا يهـــز ،

و التناؤش بالهمز : التأخير أيضا قال الثاعر :

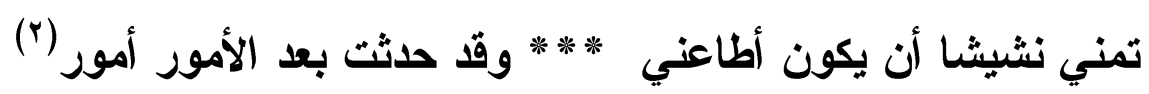

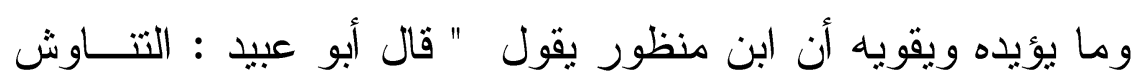

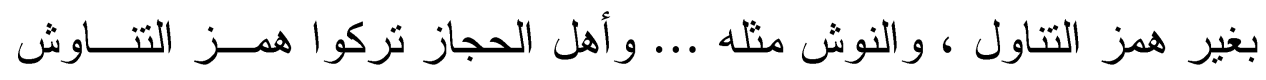

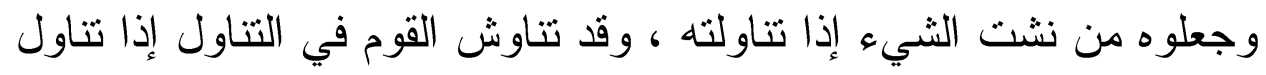

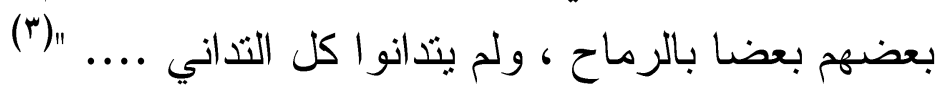

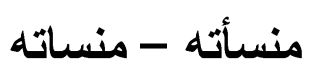

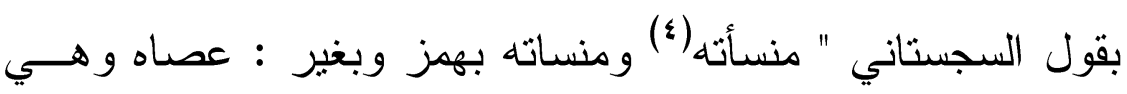

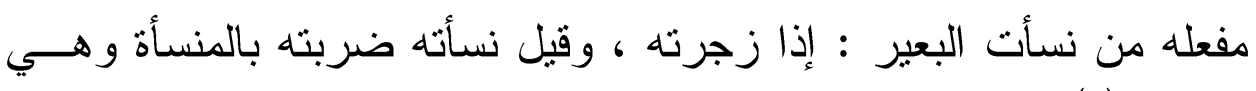

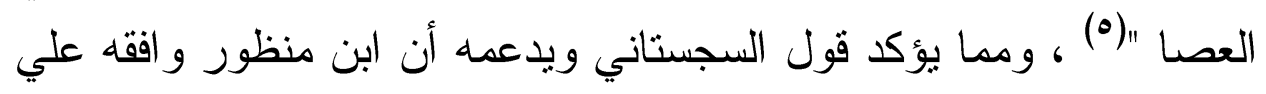

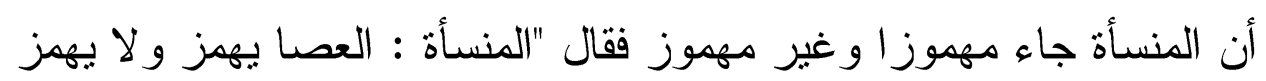

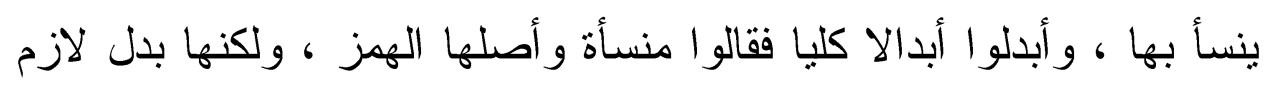

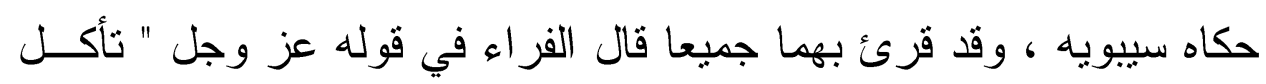

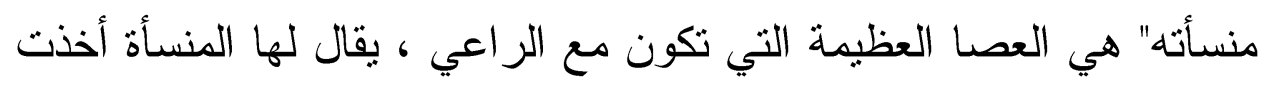

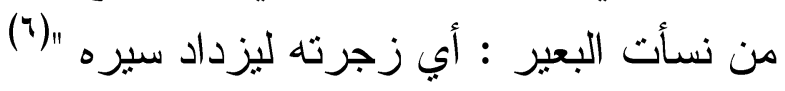

$$
\begin{aligned}
& \text { (1) من سورة سبا آية ( }
\end{aligned}
$$

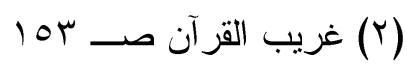

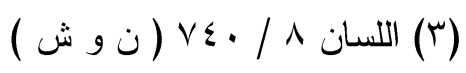

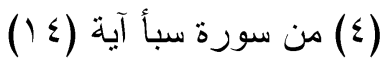

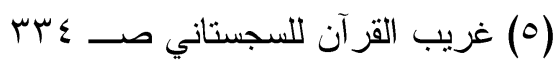

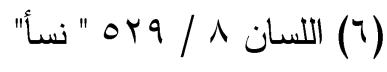




\section{الباب الثاني}

\section{الدرس الدلالي في غريب القرآن للسجستاني}

\section{ويتكون من أربعة فصول :}

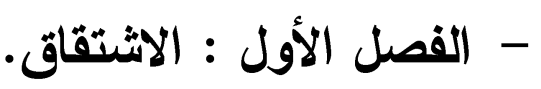

- الفصل الثاني : منهج السجستاني في شرح المعني وتفسيره. - الفصل الثالث : التطور الالالمي. - الفصل الرابع : تعدد المعني للفظ، وتعدد اللفظ للمعنى • 
_olMr

النصل الأول

9 ") 


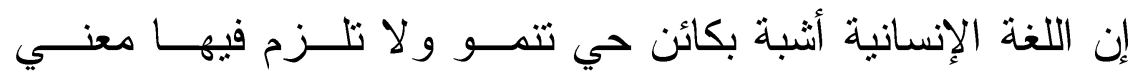

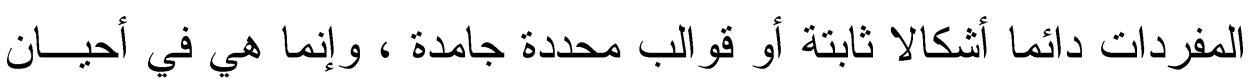
كثثرة عرضة للتغيير و التتديل ، وهذا التحرك المستمر لها يتضح هن خلال النظر إلى مدلو لاتها في حقبة زمنية طويلة .

وقضية الدلالة من القضايا المهمة في الدراسات اللغوية " لأن اللغة كما هو معروف لفظ ومعني ، ومن ثم كانت الدلالة قو ام اللغة ووظيفتها ،

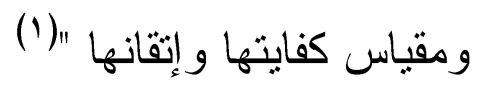
وينظم هذا العلم بحوثا كثيرة من أهمها :أ- البحث عن معاني الكلمات ، ومصادر هذه المعاني ، واختلافها في

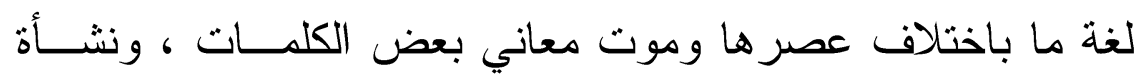

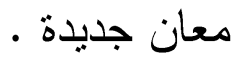

ب- البحث في القو اعد المنصلة باشنقاق الكلمات ، وتصريفها ، وتغير أبنيتها بتغير المعني "(r) هذا وقد عالج الإمام السجستاني في "غريب القرآن" قضايا نعد من

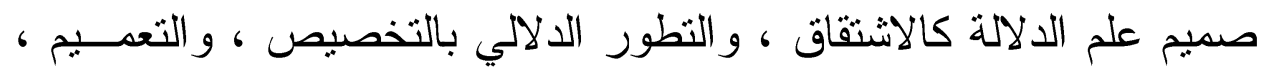

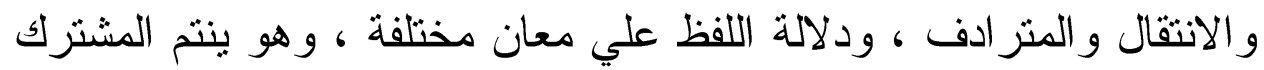

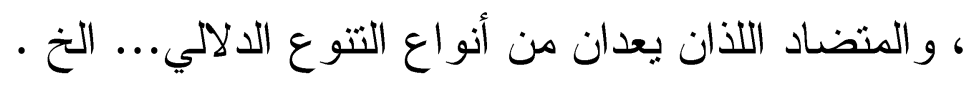

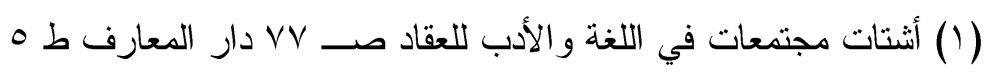

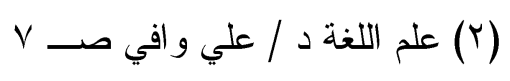


وسوف أبدا - إن شاء الله تعالي - هن بحوث علم الدلالة ب "الاثتقاق" :

1- و الاشتقاق : هو احدي الوسائل الرائعة التي تنـــو عــن طريقهــا اللغات وتتسع ويزداد ثراؤها في المفردات فتتمكن به من التعبيـر عن الجديد من الأفكار و المستحدث من الحياة " (1) وقبل الحديث عن بيان كيفية معالجة السجستاني لقضية الاثــتقاق أبدأ أو لا ببيان المعني اللغوي و الاصطلاحي لمصطلح "الاثتقاق" .

\section{المعني اللغوي للاثثنقاق :}

جاء في الصحاح الاثتقاق : الأخذ في الكلام وفي الخصومة بمينا وشمالا مع نزك القصد ، و اشتقاق الحرف من الحرف أخذه دنه(r) ، كمــا جاء في اللسان "اشتقاق الثيء بنيانه من المرتجل ، و اشتقاق الكلام الأخــذ

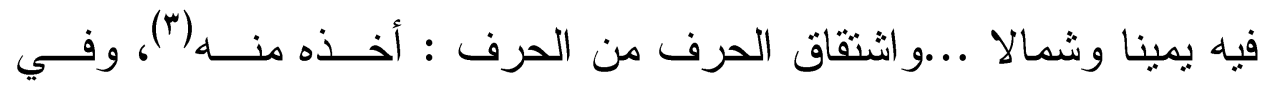
القاموس "الاثتقاق : أخذ شق الثيء ، و الأخذ في الكلام وفي الخصــومة

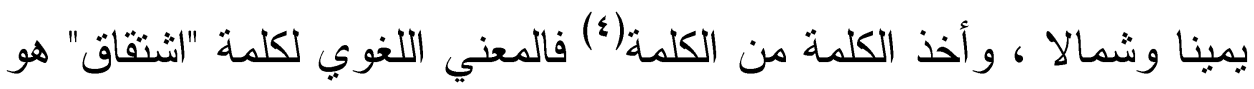
أخذ شق الشيء : أي نصفه"(•).

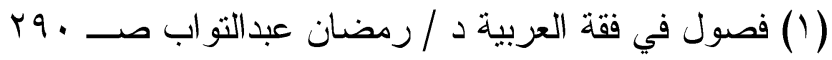

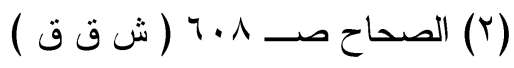

$$
\begin{aligned}
& \text { (r) اللسان 17. 17 (ش ق ق ) }
\end{aligned}
$$

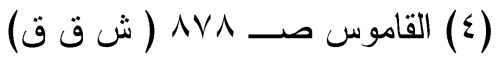

$$
\begin{aligned}
& \text { (0) علم الاشتقاق د/ جبل صــ 1. 1. }
\end{aligned}
$$


أما المعني الاصطلاحي للاشتقاق فهو عبارة عن " توليد لــبعض الألفاظ من بعض ، و الرجوع بها إلى أصل و احد ، بحدد مادتها ، ويــوحي

بمعناها المشنرك الأصيل ، مثلما يوحي بمعناها الخاص الجديد"(1). والاشتقاق علي هذا النحو بعني "استخر اج لفظ من آخر متفق معه

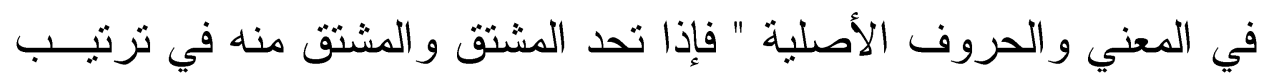
الحروف سمى هذا بالاشتقاق العام و إلا فهو الاشتقاق الكبير أو الأكبر"(؟) إلا أن هناك خلافا بين علماء اللغة المحدثين حول أنواع الاشتقاق ومدلول كل نوع : فعبد الله أمين في كتابه الاشتقاق يجعل الأنواع أربعة : صغير ، وكبير ، وكبار ( بالتخفيف) أو أكبر ، وكبار (بالنشـديد) ويعنـي

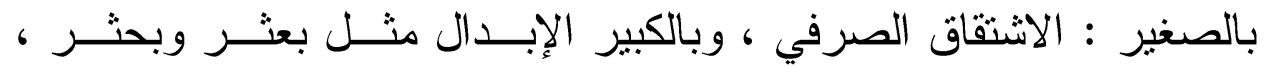

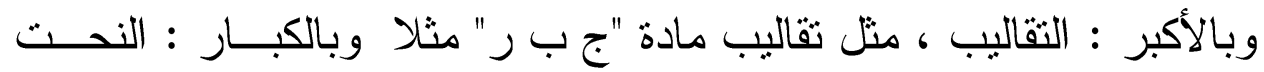
منل : بسمل وحمدل(ّ). أما الاكثور علي عبدالواحد و افي : فيجعل أنواعه ثناثة العام و الكبير و الأكبر • فالعام هو الصرفي ، و الكبير هـــ التقلبــب ،

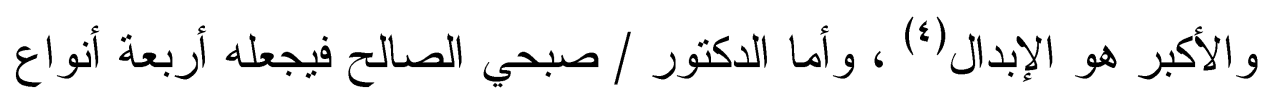
: الأصغر وهو الصرفي ، و الكبير : وهو التقليب ، و الأكبر وهو الإبدال ،

و الكبار وهو النحت. (•)

$$
\begin{aligned}
& \text { (1) فصول في فقة العربية د / رمضان عبدالتواب صـ • بـ }
\end{aligned}
$$

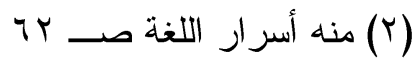

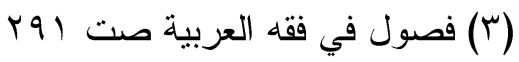

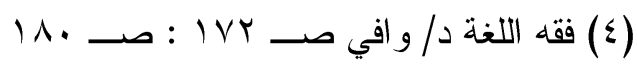

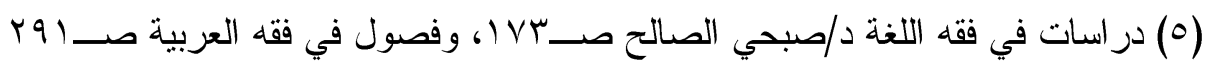


و الذي يههنا من هذه الأنواع هو النــوع الأول وهـــو الاشــثقاق

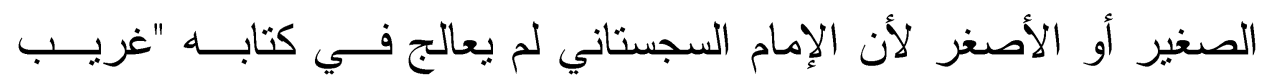
القر آن" سوى هذا النوع من الاشتقاق.

فما المقصود بالاشتقاق الصغير أو الأصغر ؟

عرفه السيوطي بقوله " أخذ صيغة من أخري ، و اتفاقهما معني ، ومادة أصلية وهيئة نركيب لها ، ليدل بالثانية علي معني الأصل ، بزيــادة

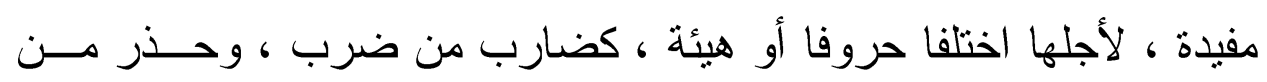

حذر "(1)

وهذا النوع هو المعني عند الإطلاق ، ولهذا يسمي : " الاشـتقاق

العام" أو " الاشتقاق الصرفي "لأنه الذي تتصرف الألفاظ عــن طريقـهـ ، ويشتق بعضها من بعض، ومعني هذا افتر اض الأصالة في بعض الألفاظ ، و الفرعية في بعضها الآخر، و هنا يختلف النحاة في أصل المشتقات، فيري البصريون أن المصدر أصل المشتقات ، لكونه بسيطا أبي يدل علي الحدث فقط ، بخلاف الفعل فإنه يدل علي الحدث و الزمن ، أما الكوفيون فيعـدون الفعل أصلا للمشتقات لأن المصدر يجئ بعده في التصريف فيقال مــنالا :

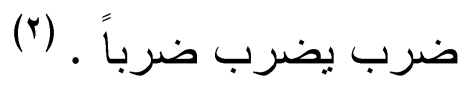
أقسام الاشثقاق الصغير : قسم الدكثور / جبل : الاشتقاق الصغير إلى قسمبن فقال :

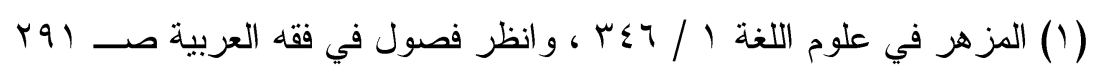

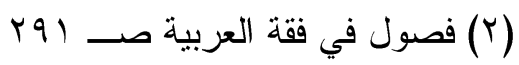


" در اسة الاشتقاق الصغير تقود إلى تقسيمه فسمين : فهو إما لفظي

و إما دلالي. فالاشتقاق اللفظي : هو ما نكون ثرته لفظية فقط تتمنل فـي إنشاء صيغة جديدة توجه المعني الحرفي للمأخذ (وهو المعني الذي وضعت هوت

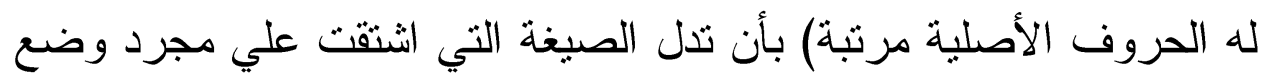

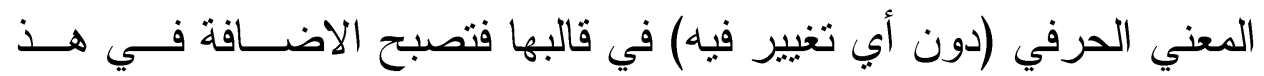

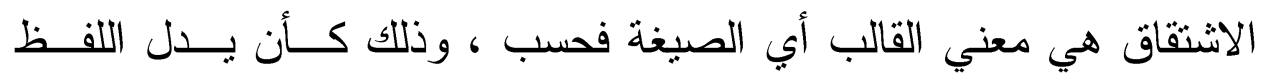
المشتق علي فاعل المعني الحرفي إذا كان علي صيغة اسم فاعل أو بــــل علي ما وقع عليه المعني الحرفي : إذا كان علي صبغة اسم مفعــول ، أو

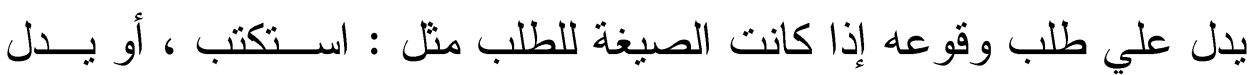
علي كثرنه في المكان منتل مسبعة ... الخ. أما الاشتقاق الدلالي : فهو ما تكون ثرته دلالية بأن تكون الكلمة المشتقة ذات معني = دلالة جديدة مستمدة من معني المأخذ كمـــا نقــول : ابتسر الرجل حاجته : أبي طلبها قبل أوانها أو قبل استحقاقها ، أخــذا مــن البسر وهو البلح الغض الذي لم ينضج (لم يحن أوان أكله) ، وكما اثــتق الزهد (بمعني صدوف النفس عن قبول أمر فيه متعه أو إغر اء تتزهــا أو تخشنا) من الأرض الزهاد وهي الصلبة المصدنة التي لا تقبل الماء الذي يصب عليها ( أي لا نشربه بل يسيل علي سطحها ) و هكذا"(1) و الذي يههنا من الاشتقاق الصغير بقسميه (اللفظي و الدلالي) هـــو القسم الثاني الدلالي ، وذلك لأن السجستاني قد عالجه في كتابــه "غريــبـ القر آن" علي المستوبين الجزئي والكلي -كوسيلة- من وسائل كثف المعني و إيضاحه كما سنري فيما بعد. 
والآن فماذا في كتاب " غريب القرآن " عن بحث الاشتقاق:

عالج الإمام السجستاني الاثــتقاق الــدلالي بمســتوييه الجزئـي

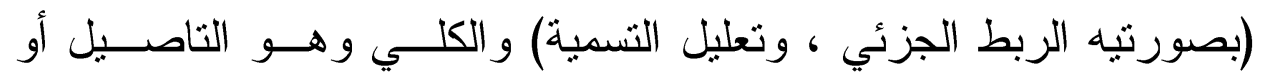

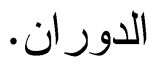

الصورة الأولي من الاشتقاق الجزئي = الربط الاشتقاق الجزئي.

وفي هذه الصورة ينصب الأخذ الاشتقاقى أو الربط الاشتقاقى علي كلمتين بأعيانها من جهة المعني ، فإحدى الكلمتين هي المأخذ ، و الأخري هي الكلمة المشنقة سو اء استحدثناها أخذ أو وجدناها ربطــا ، و اعتـددناه جزئيا لقصر النظر فيه علي المأخذ والمشنق دون النظر إلى شقائق المأخذ

$$
\text { أي سائر مفردات جذره ، و استعمالاته (1). }
$$

ومن أمثلة الاشتقاق علي هذا المستوي ما نلمحه من الإرنباط بين استعمالين أو استعمالات من نزكيب و احد كالارنباط بين المــرق ومــروق

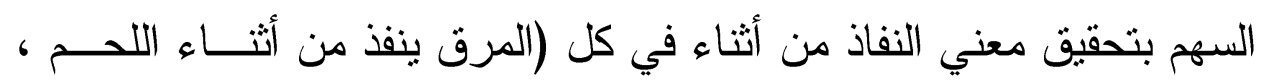
و السهم من أثناء الرمية ) مئن

وبين القمر والمقامرة بتحقيق معني التز ايد شيئا فشيئا في كل القمر

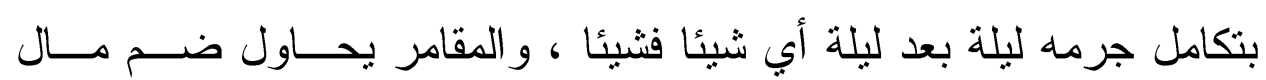
صاحبه إلى مال نفسه مرة بعد مرة .

وبين الحجر و الحجرة بتحقيق معني امتتاع الاختر اق أو الاقتحـــام في كل (r) وقد عالجه السجستاني في سبعة عشرومائة موضع مــن كتابــهـ 
"غريب القر آن" تقريبا وسأذكر نماذج من عمله ثم اكتفي بالإحالة إلـى مــــا تبقي من هذه المو اضع ·

من ذلك قوله " أسلمت لرب العالمين "(ا) أي سلم ضميري لــهـ ،

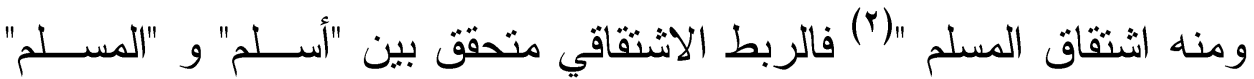
بتحقيق معني الانقباد في كل ، وقوله أيضا " أغضض من صونلك"(") انقص

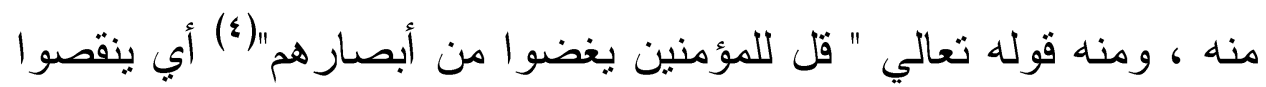

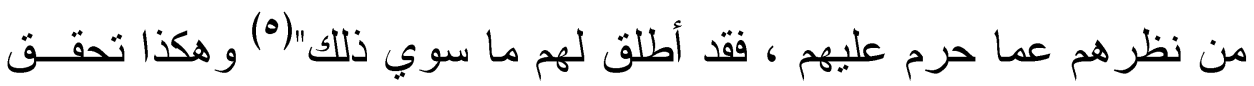
الربط الاشتقاقي -كما نرى- بين هاتين الكلمتين ( أغضض - ويغضــوا) و هو النقص في كل ذلك أن الغاض من صوته يخفضه فلا يرفعه ، وكــذا

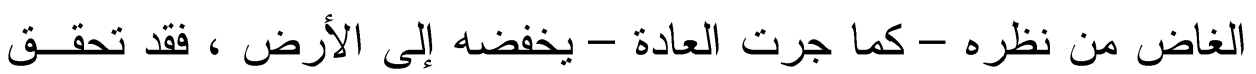
النقص في كليهما. وقوله " أوجفتم" (") من الايجاف وهو السير الســريع "(V) فــالربط الاشتقاقي بين "الإيجاف" المأخذ أو المشنق منه و"أوجف" المشتق وهو السير السريع منحقق في كل منهما.

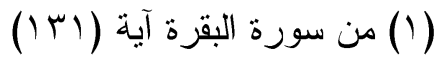

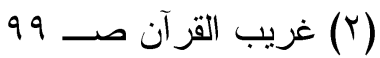

$$
\begin{aligned}
& \text { (Y) من سورة لقمان آية (19) (19) }
\end{aligned}
$$

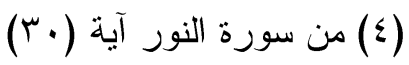

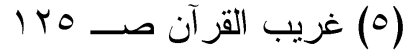

$$
\begin{aligned}
& \text { (T) من سورة الحشر آية (T) عزب (1) }
\end{aligned}
$$

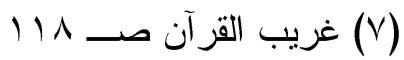


وقوله " أذله علي المؤمنين "(1) أي بلينون لهم ، من قوله : دابـــة ذلول أبي لين منقاد ليس هذا من الهوان إنما هو من الرفق"(r) ، فمعني اللين و الانقياد ملحوظ ومتحقق في كل من المشتق ( أذلة) و المشتق منه (ذلول). وقوله "أهل به لغير الله"() ذكر عند ذبحه أسما غير الله ، و أصل

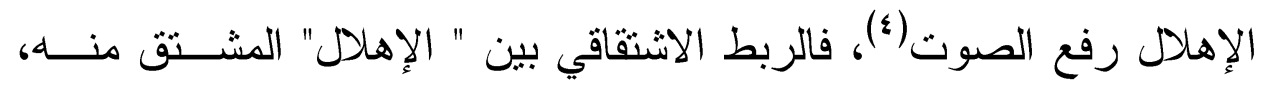
و "أهل" المشتق متحقق في كل منهما ذلك أن المعني الجامع بينهما هو" رفع

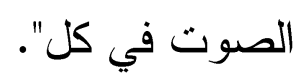

نتبين من الأمثلة السابقة أن الإمام السجستاني قد استخدم في هـذذه الصورة من الاشتقاق الجزئي العبارات التالية:- اشتق من كذا أو مـــأخوذ من كذا أو من قولهم كذا أو أصله من كذا ........ إلخ. كما أنه قصد بقوله مأخوذ من كذا أو من قولهم كذا أو أصله مــن كذا ... الخ : مشتق من كذا، وقد مضي علي هذا النحو في جل معالجاتــــ للألفاظ الغريبة في القرآن الكريم ، وقد استطاع بهذه الوسيلة كثنف اللثـام عن الغريب من الكلمات القر آنية.

هذا وشو اهد هذا النوع كثيرة في "غريب القر آن" للإمام السجستاني

وللمزيد يرجع إلى تعليقاته علي،الكلمات التالية:- الأســباب صـــو 99

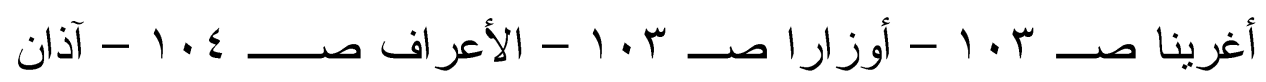

$$
\begin{aligned}
& \text { (Y) من سورة البقرة آية (IVY) }
\end{aligned}
$$

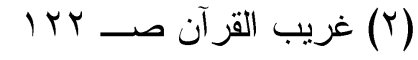

$$
\begin{aligned}
& \text { (Y) من سورة البقرة آية (Yr (Y (Y) }
\end{aligned}
$$

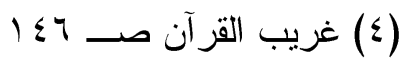




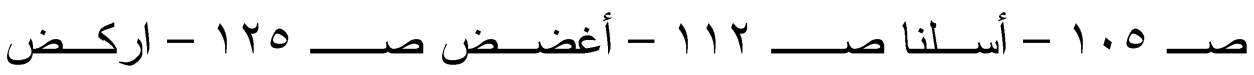

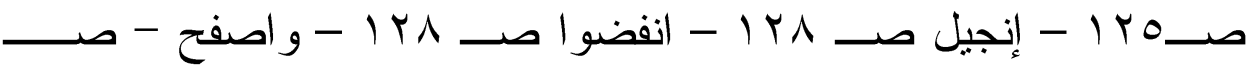

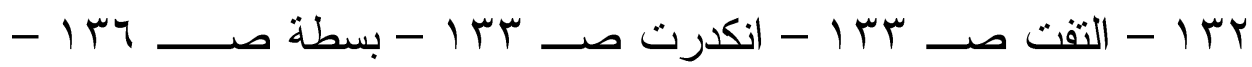

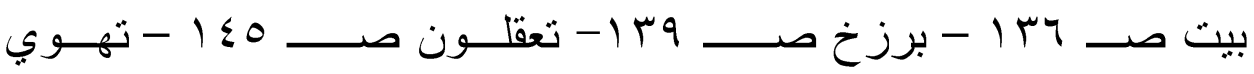

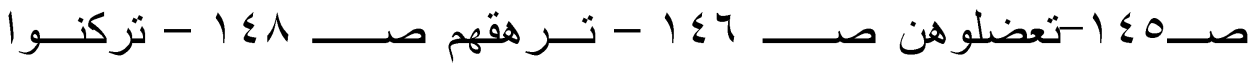

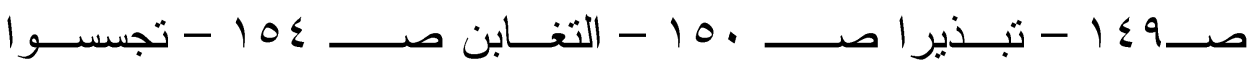

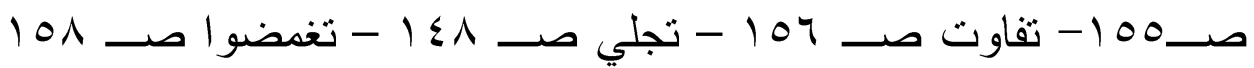

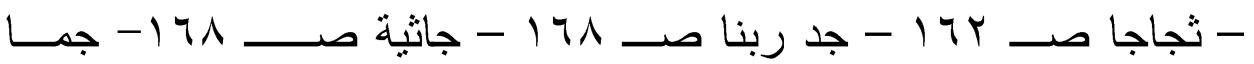
صـ111 - جوار في البحر صـ 171 - حفي عنها صـ IVT - حاثا

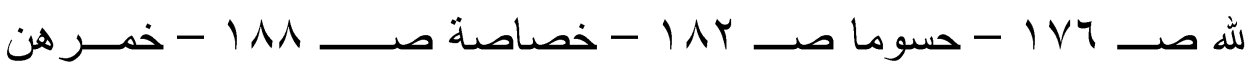

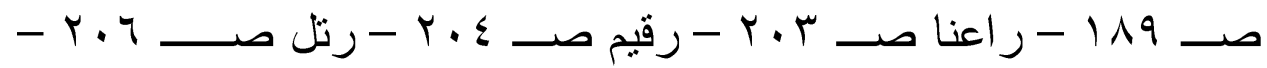

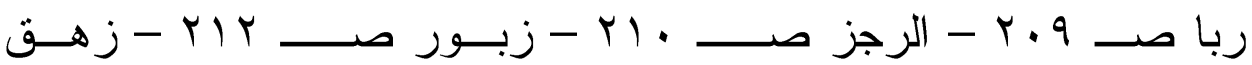

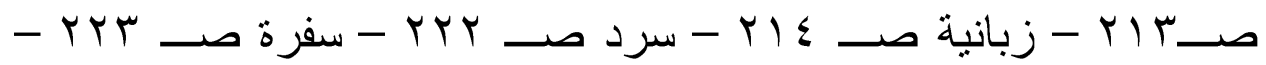

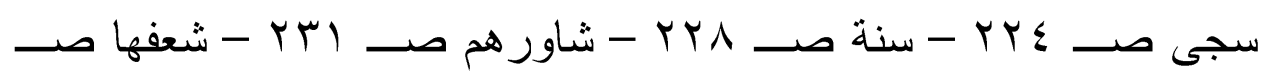

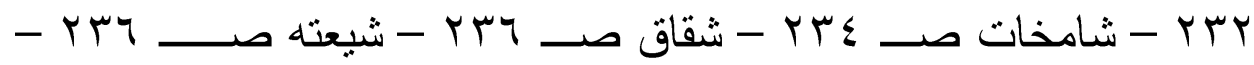

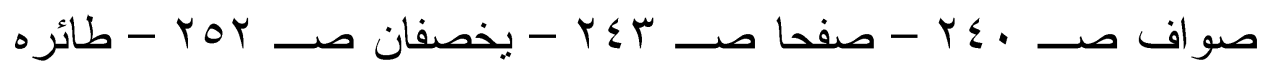

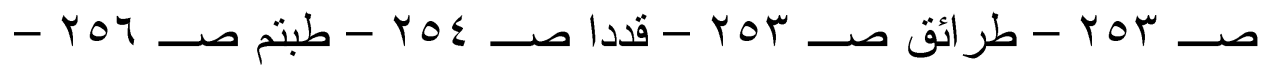

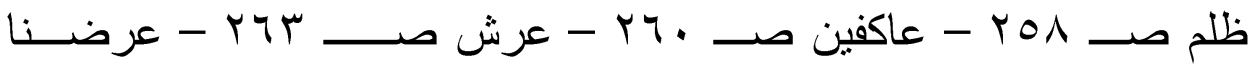

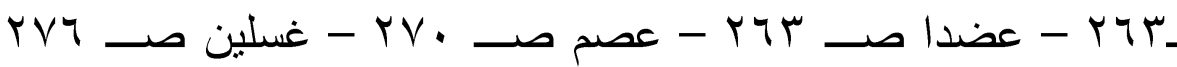

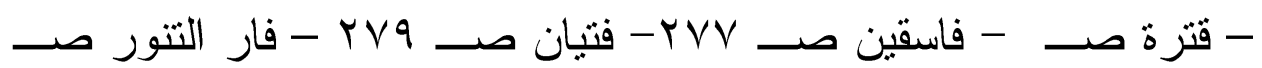

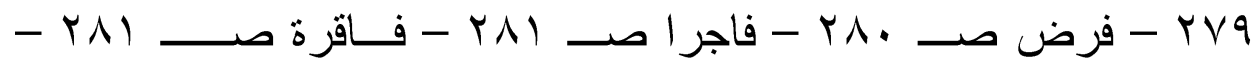

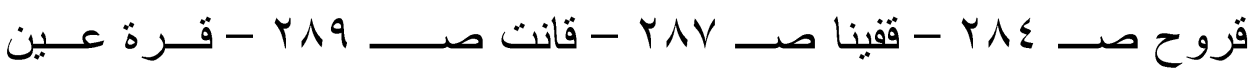




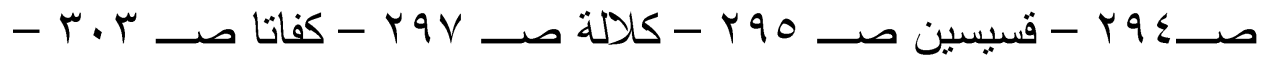

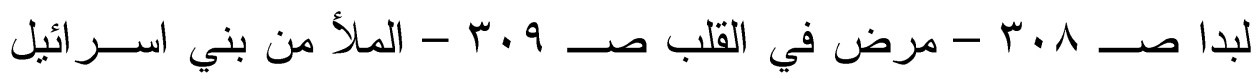

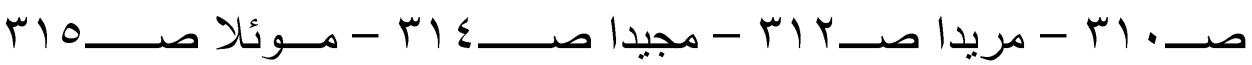

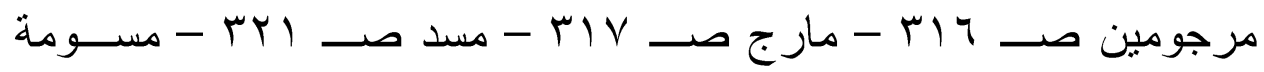

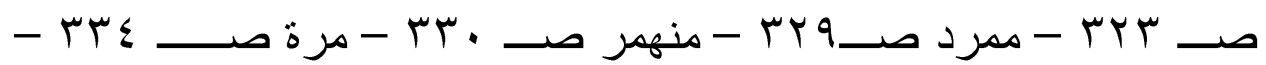

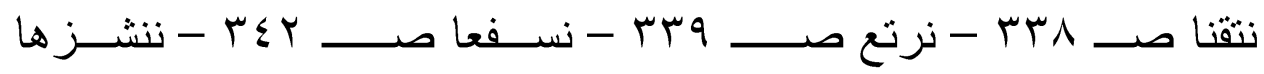

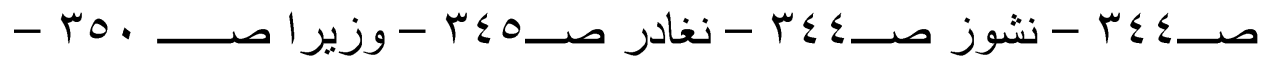

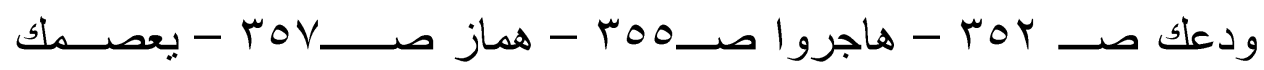

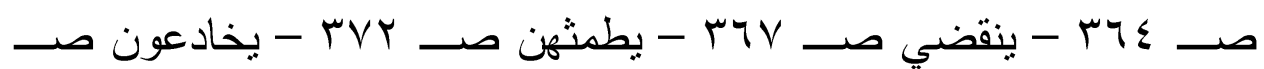

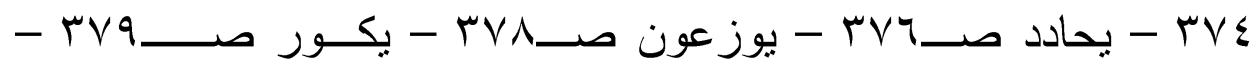
يزلقونك صــ. 


\section{الصورة الثانية من الاشتقاق الجزئي " تعليل التسمية" :}

أما فيما يتعلق بالصورة الثانبة من الاثتقاق الجزئي فهي المتمثلة

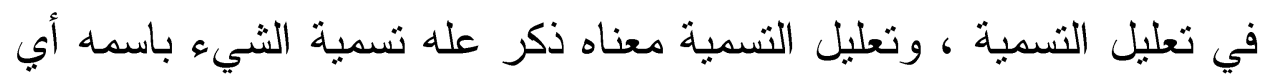
وجه هذه التسمية ، وعله النسمية هي عين الملحظ الاشتقافي الذي من أجله

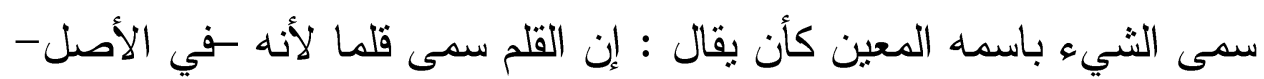

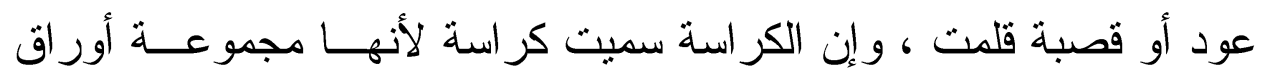

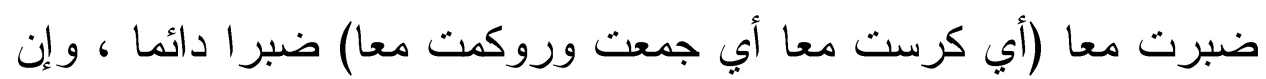

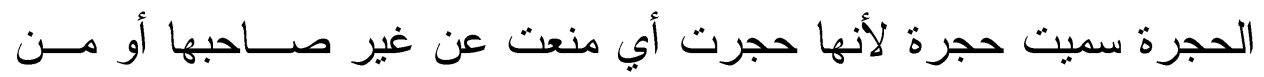

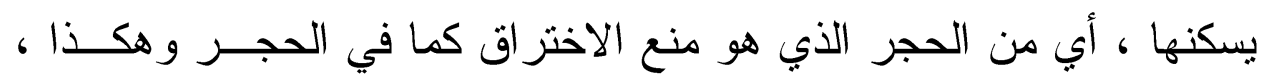

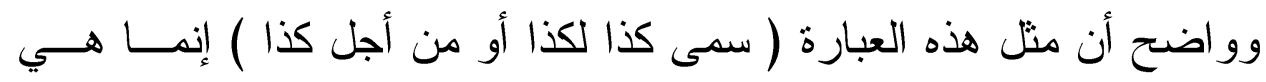
تعبير آخر عن الربط الاثنقاقي بين كلمنين فكما قلنا هنالك إن الزهد هد بالضم

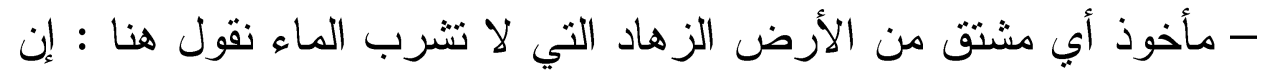

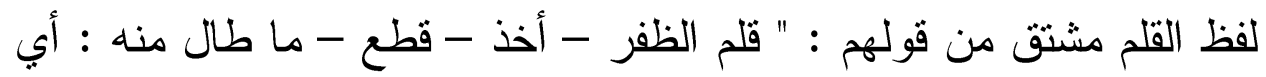
طرفه فكذا القلم كان في أصله قصبة أخذ طرفها ، وهكذا ، ولذا جعلنا هذا

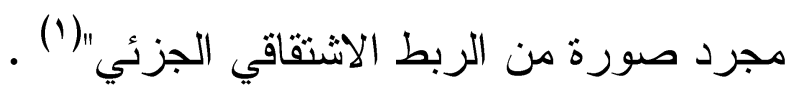
هذا وقد عالج الإمام السجستاني هذه الصورة من الاثــتقاق فــي

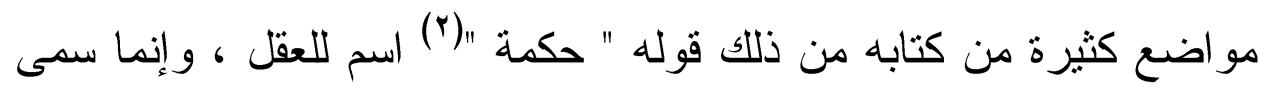

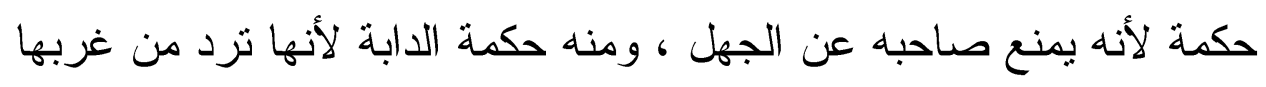

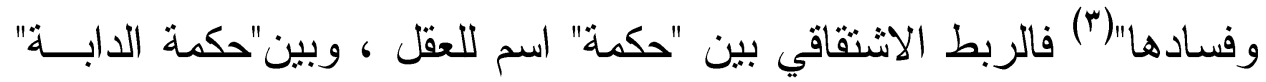

$$
\begin{aligned}
& \text { (1) ينظر علم الاثنقاق د / جبل صـ 11) } \\
& \text { (Y) (Y) من سورة هود آية (IIT) } \\
& \text { (ץ) غريب القرآن صـ }
\end{aligned}
$$


ملحوظة دن خلال ذكر عله التسمية وهي قوله لأنها نزد (أي تمنــع) مــن غربها وفسادها فمعني " المنع منحقق في كل من المشتق منه "حكمة" بمعني العقل ، و المشتق حكمة الدابة فكما أن الحكمة (العقل) تمنع صـــاحبها عـنـ الجهل فكذلك الحكمة نمنع الدابة عن عبثها وفسادها .

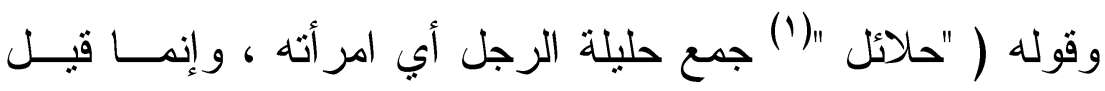

لامر أة الرجل جليلة وللرجل حلبلها لأنها تحل معه ويحل معهــا ، ويقــال

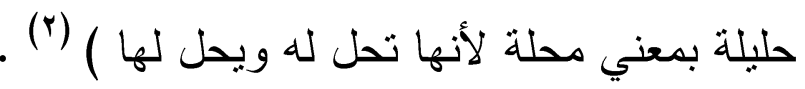

كذلك نلحظ الربط الاشتقاقي بين كل من المشتق منه ، و المشــتق ذلك أن حلائل مشتق إما من الإحلال بالمكان أو هن الحلال الذي هو ضـــ الحر ام يوضح ذلك قوله و إنما قيل لامر أة الرجل حليلة وللرجل حليلها لأنها تحل معه ويحل دعها ، ويقال حليلة بمعني محلة لأنها تحل له ويحل لها. وقوله ("حاقة "(") يعني القيامة سميت بذلك لأن فيها حواق الأمور : أي صحائح الأمور) (\&) كذلك نلحظ الربط الاشتقاق بين كل من المشــتق منه حواق الأمور بمعني صحائح الأمور و المشتق الأبي هو كلمـــة "حاقــة" بمعني القيامة ذلك أن الحق و الصدق متحقق في كل منهما. 
وقوله ( "مسيح"(1) فيه ستة أقو ال قيل سمى عيسي عليــه الســلام

مسيحا لسياحته في الأرض ...، وقيل مسيح : فعيل من مسح الأرض لأنه كان بمسحها أي يقطعها ، وقيل سمي مسيحا لأنه خرج مــن بطــن أمسـه

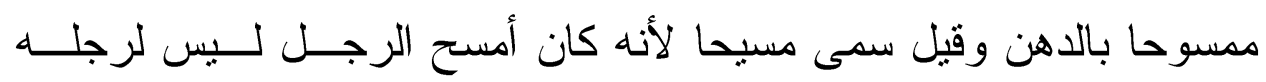

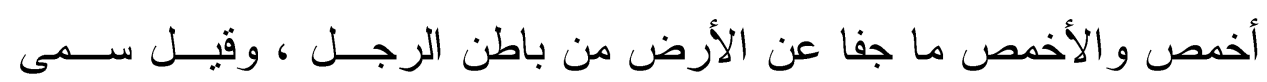

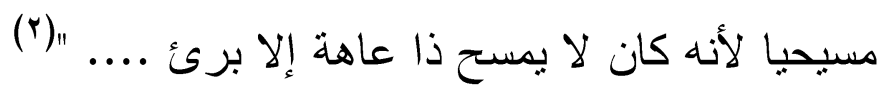
فالربط الاشتقاقي و اضتح بين المشتق منه وهو "المسحت" - أبا كــان نوع هذا المسح سو اء من مسح الأرض أو غيره - إلخ - و المشتق "المسيح" هذا وهناك أمثلة كثثرة لهذه الصورة من الاشتقاق الجزئـي التـي تقوم علي تعليل التسمية ، وللمزيد من النماذج التي تتضوي تحـــ هــذه الصورة فإنني سأكتفي بالإحالة إلي تعليقات المؤلف علي الكلمات التاليــة : الألباب صــ . . - بكة صـ حسا - العتيق صـ وسا - تزاور صـ

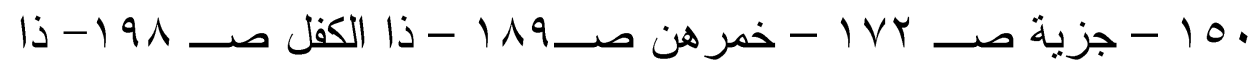

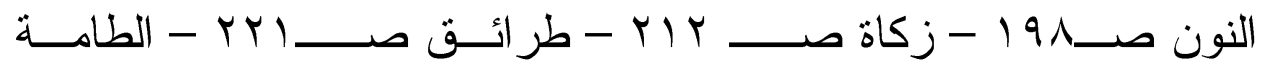

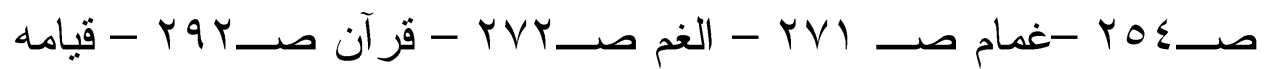

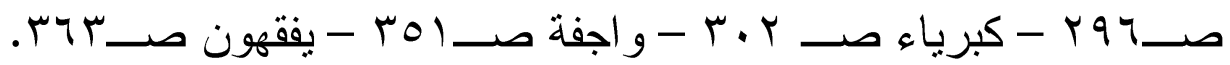
فالكلمات التي عالجها السجستاسني تحت هذه الصورة : قد بلغـــ نحو ا من اثثتين وعشرين كلمة تقريبا ـ كما بلغ مجمــوع الكلمـات التـي عالجها تحت الصورة الأولي من الاشتقاق الدلالي الجزئي نحو ا من ســبع

$$
\begin{aligned}
& \text { (1) من سورة أل عمران ( (1) }
\end{aligned}
$$

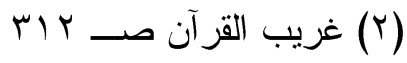


عشرة كلمة ومائة تقريبا كما ذكرت سالفا إذن يكون مجموع الكلمات التـي عالجها ، و التي تتدرج تحت ما يسمي بالاشتقاق الجزئي بصورنيه نحوا من تشع وثلاثثين ومائة كلمة تقريبا.

وفي ضوء هذه المعالجات الكثيرة لهذا النــوع مــن الاثــتقاق .

نستطيع أن نقول إن السجستاني : يعتبر - بحق - من هؤلاء العلماء الرواد الذين وظفو الاشثقاق الجزئي بصورنيه بالإضافة إلي الكلي - كما سنري فيما بعد - كوسيلة من وسائل كثف معني اللفظة القر آنبة و إيضاحها . r- المستوي الثاني من الاشتقاق الدلالي : الكلي أو الدوران عند السجستاني ، وحقيقة الاشتقاق الكلي أو الدوران أنه "ربط كل اســتعمالات الجذر الواحد بمعني عام تدور عليه وترجع إليه" (1) وقد عالجه السجستاني في أكثر من موضع من كتابه من أمتلة ذلك

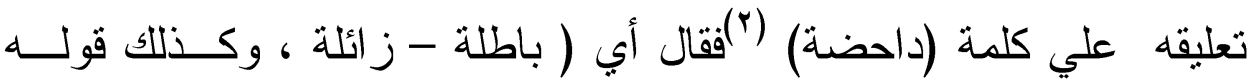
(لبدحضو ا به الحق ) (ّأي ليزيلو ا به الحق ، ويذهبو ا به ، ودحض هو أي زل ، ويقال مكان دحض : أي مزل مزلق لايثبت فيه قدم ولا حافر. (؛) وهكذا نري أن السجستاني قد أدار تركيب ( دحض) حول معني و احد هو "الزو ال" وقد أرجع إلى هذا المعني الاستعمالات التالية : داحضة

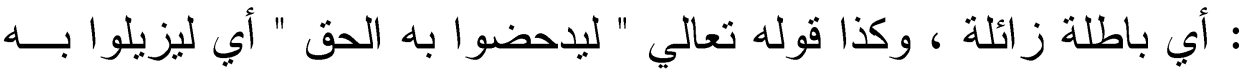

$$
\begin{aligned}
& \text { (1) علم الاشتقاق د/ جبل صـ } 79 \\
& \text { (Y) من سورة الثوري آية (T) }
\end{aligned}
$$

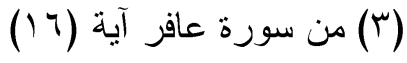

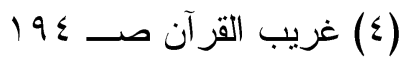


الحق ويذهبوا به ، ودحض بمعني زل ، وكذا مكان دحض : أبي مـزل لا

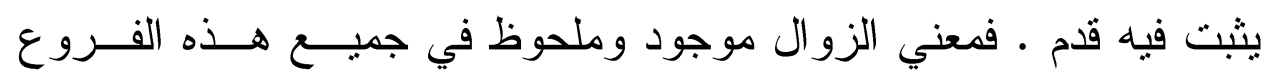

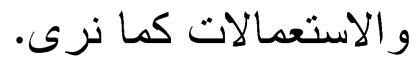

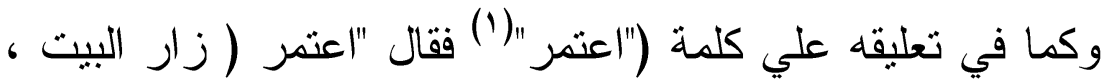

و المعتمر : الزائر قال الثاعر :--ور اكب جاء من تثليث معنمر .

ومن هذا سميت العمرة لأنها زيارة للبيت ، ويقال اعنمر أب قصد

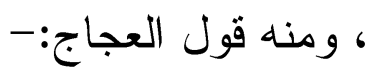

\section{لقد سما (بن معمر حين اعتمر ... مغزي بعيدا من بعيد وضبر)(؟)}

كما نتبين من ذلك أن السجستاني قد أدار ما جاء في هذه التزكيب

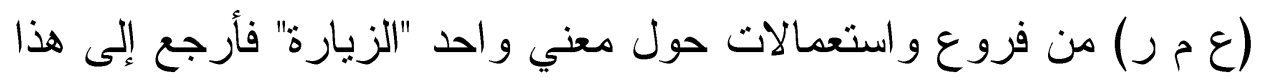

المعني اعتمر فقال أب زار ، و المعتمر : الزائر، و العمرة :الزيارة...الخ.

كما علق علي كلمة "غفور"(") فقال ( "غفور : أي ساتر علي عباده

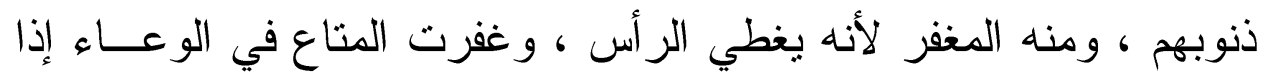

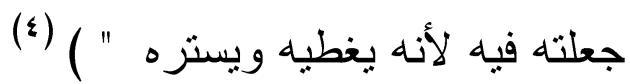

كمما نر اه قد أدار ما جاء من فروع في نركيب ( غ ف ر ر) حـول

معني واحد هو "الستر و التغطية" وقد أرجع إلى هذا المعني الفروع التالية :

$$
\begin{aligned}
& \text { (1) من سورة البقرة آية (1) (Y) } \\
& \text { (Y) غريب القرآن صـ (Y) }
\end{aligned}
$$

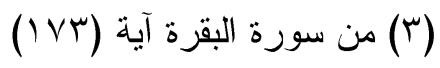

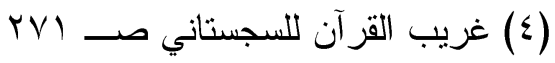


غفور : أب سانر علي عباده ذنوبهم - و الدغفر الذب يغطي الرأس ، وغفر المتاع في الوعاء إذا وضعه فيه لأنه يغطي الر أس وهكذا. وكما علق علي كلمة "ينركم"(1) فقال " يتركم : ينقصكم ويظلمكم

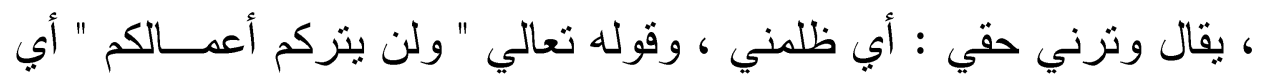

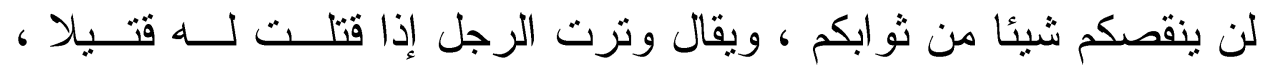

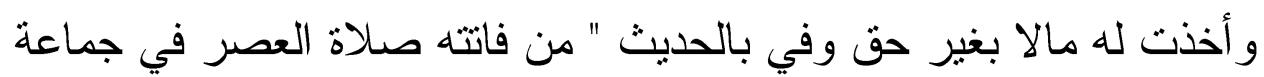

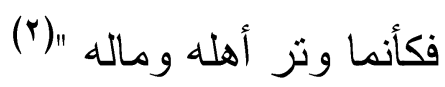
وهكذا نجده قد أدار نركيب (وتر) حول معني واحد هو "النقص" وقد :

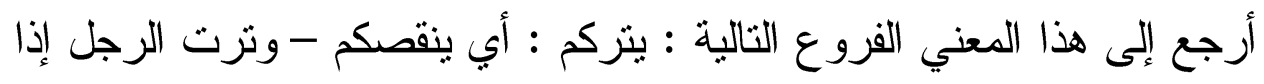
قتلت له قتنلا ، وكذا وتز أهله لمن فاتته صلاة العصر في غير جماعة وهكذا. هذا ونكتفي بالإحالة إلى تعليقاته علي الكلمات التاليــة : الأنفــال

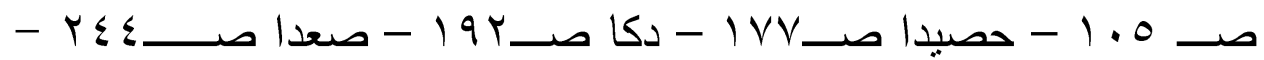
ممرد صـ

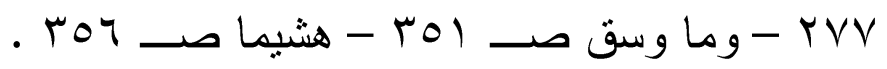
نتبين من ذلك أن شو اهد الاشتقاق الكلي أو الدوران كانـــت قليلـــة بالنسبة لثو اهد الاثتقاق الجزئي حيث لم نزد عن خمس عشرة كلمة تقريبا. إذن يكون مجموع الكلمات التي عالجها تحت الاثــثقاق الـــلالي

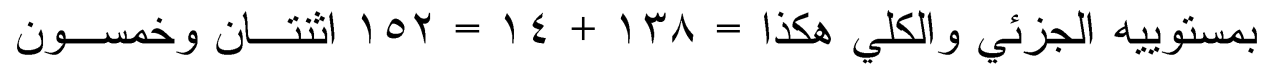

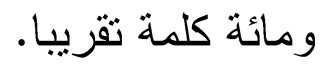

$$
\text { (Y) (Y) من سورة محمد آية (ro) }
$$


و علي كل حال فإننا من خلال هذه المعالجات الكثيــرة للاشــتقاق الدلالي بمستوييه نستطيع أن نتبين كيف وظف هذا الإمام الجليل الاثــتقاق الدلالي بمستوييه (الجزئي و الكلي ) فجعله وسيلة من وسائل كثف المعنـي و إيضاحه عن الكلمات الغريبة في القرآن الكريم ولذلك يقول ابن الســراج (ت آسهـ) إن الاشتقاق هو أكمل الطرق في تعريف مدلو لات الألفاظ

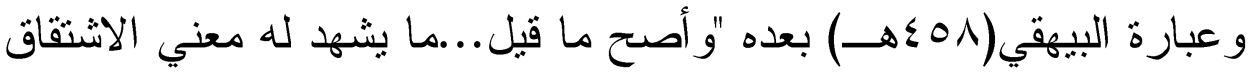
"ودن هنا شاع الاستناد إلى الاشتقاق في كتب التفسير و الثروح.(') كما أنه بالرجوع إلى الاشتقاق يحسم الخلاف في معني الكلمة ومن أمثلة ذلك ما جاء في معني "الصمد" اسم الله عز وجل : فقد أورد البيهةـي في "الأسماء و الصفات" نحو سبعة معان منها : المصــمود بــالحو ائج أبي المقصود بها و الذي كمل في أنو اع الثرف و السؤدد : العظمة و الحلم و العلم و الحكمة و الجبروت ...، و الذي لا جوف لله ، و الذي لم يلد ولم يولا ولـــ يكن لله كفو أحد ، و الذي لا يخرج منه شيء ، و الذي لا يأكل و لا يشرب ، و الباقي بعد خلقة ، ثم قال " قال أبو سليمان الأشعث : الصمد : السيد الذي يصمد إليه في الأمور ويقصد إلبه في الحوائج و النوازل ، و أصل الصــمد (بسكون الميم) القصد ، يقال للرجل أصمد صمد فلان : أي اقصد قصده ، و أصح ما فيل ما بشهد له الاشتقاق " ا هـــ أبي أنه استقر علي المعني الذي بدأ به مستندا إلى الاشتقاق". (r) هذا وقد حقق الإمام السجستاني في تفسيره هاتين الغــايتين عـنـ طريق لجوئه إلى الاشتقاق الدلالي بمستوبيه الجزئي والكلي. 
-010..

\section{الفصل الثاني}

طرق شرح المعني وتفسيره

$$
\text { في }
$$

غريب القرآن للسجستاني 


\section{طرق شرح المعني وتفسيره في "غريب القرآن" للسجستاني:}

عندما درست كيفية معالجة السجستاني لثرح المعنـي فـي تفسـيره

"غريب القر آن" نبين لى أنه قد استخدم عدة طرف لتحقيق هذا الأمر فمن ذلك: -

- - التفسير بمرداف مفرد كقوله : بغيا : فاجرة (1)، وكقوله : شانئك :

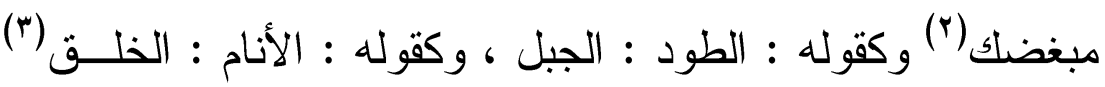
•آخ....

r- التفسير بمر ادفين كقوله : أزري(|) : عوني وظهري ، وقولـهـ :

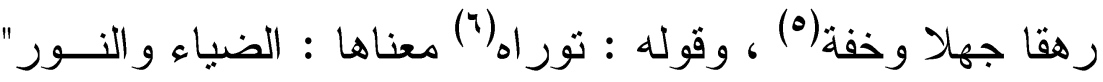

$$
\text { وقوله : أجاج(v) مر شديد الملوحة. }
$$

ץ- التفسير بالنقل من اللغات الأخري كقوله : صلوات(^) يعني كنائس اليهود وهي بالعبر انية : صلوتا ، وقوله : التين و الزيتون(9) جبلان

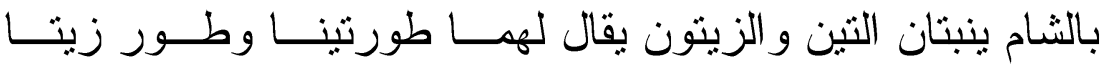

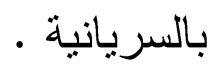

\begin{tabular}{|c|c|c|}
\hline \multicolumn{3}{|c|}{ (1) غريب القرآن صـــ وسا } \\
\hline صـ & 66 & $6(Y)$ \\
\hline صــ سor & 66 & ، (ب) \\
\hline صـ 11V & 66 & 6 ( $(\varepsilon)$ \\
\hline صــ T. & 66 & $6(0)$ \\
\hline صــ & 66 & $6 \quad(7)$ \\
\hline صــ & 66 & $6(V)$ \\
\hline صــ & 66 & $6(\wedge)$ \\
\hline صــ171 & 66 & $66 \quad(9)$ \\
\hline
\end{tabular}


ع - التفسير بالعبارة : و هذا بعني أنه يشرح دلالنه شرحا موجز ا يسير ا كقوله : أثر اطها : علاماتها ، ويقال : أثرط نفسه للأمر إذا جعل

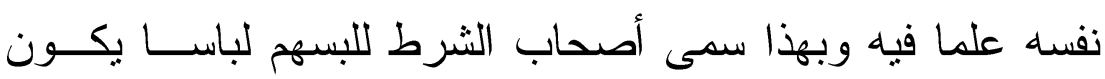
علامة لهم ، و الثرط في البيع : علامة من المنبايعين. (1)

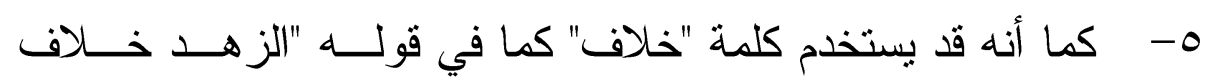

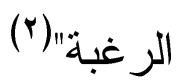

؟- شرح المعني بالمغايرة() كأن تكون الكلمة من قبيل المشنرك منل

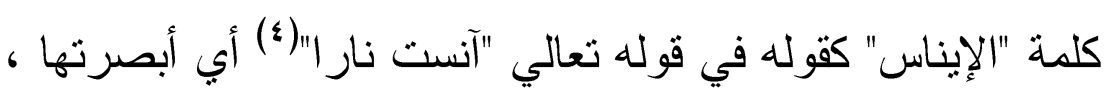
و الإيناس الرؤية و العلم والإحساس بالثيء(•)، أو يقول معلقا علي

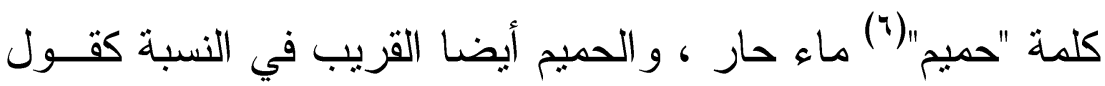
تعالي " ولا بسأل جميم حميما "(v) أي قريب قريبه و الحميم أيضـــا

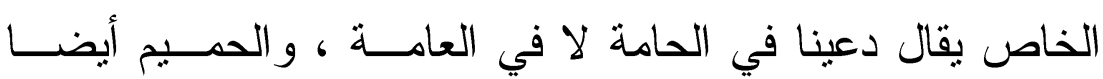
العرق(^) وكقوله : أزفت الآزفة : قربت القيامة سميث بذلك لقربها ، ويقال أزف شخص بني فلان أي قرب ، وقولـــه جـلـ وعــز "

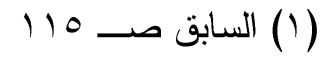

Y)

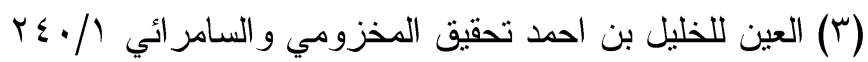

$$
\begin{aligned}
& \text { (1) من سورة طه آية (1) (1) }
\end{aligned}
$$

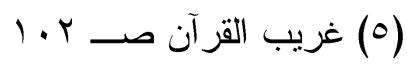

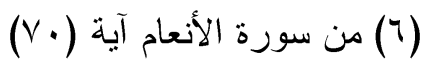

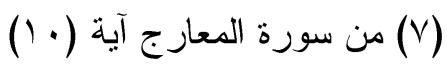

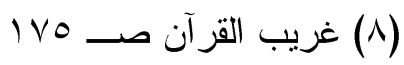


وأنذرهم يوم الآزفة : أي يوم القيامة "(1) وكقوله : الأنفال : الغنائم

و احدها نفل و النفل : الزيادة ، و الأنفال : مما زاده الله عز وجـلـ هذه الأمة في الحلال لأنه كان محرما علي مــن قـبلهم ، وبهــذا

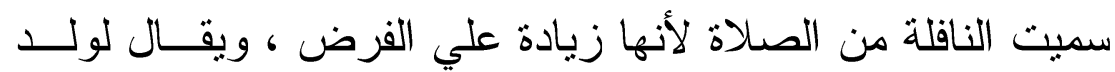
الولا الناقلة لأنها زيادة علي الولد " (ץ).

-V

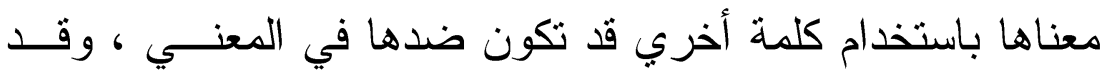

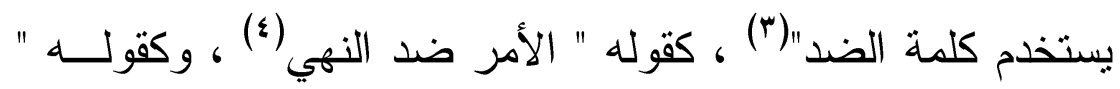
كفر ضد الإيمان (ه) وكقوله والجهل : ضد العلم(؟) ، وقوله : سر ضد : علانية(V) وقوله " شك : ضد اليقين"(^)

$$
\begin{aligned}
& \text { (1) من سورة غافر آية (1) (1) }
\end{aligned}
$$

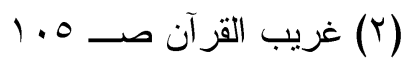

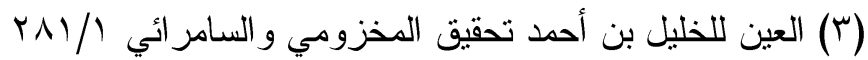

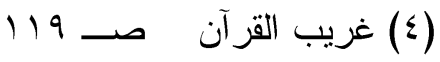

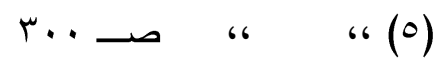

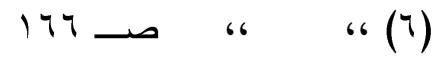

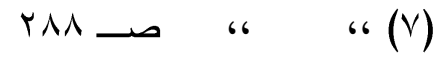

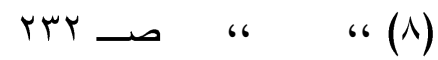


$-010 \varepsilon-$

الفصل الثالث

التطــــور الـــلـلالي 


\section{التطور الدالمى : - الت}

إن التقكير الإنسانى ، و الألفاظ التى تحمله ، وتعبــر بــهـ عـن

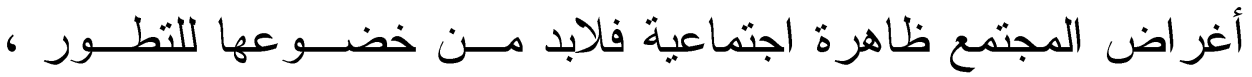

و التغير ، و هذه سنة الحياة ولن تجد لسنة الله تبديلا (').

فتطور الدلالة ظاهرة شائعة فى كل اللغات يلمسها كـلـل دارس

لمر احل نمو اللغة و أطوارها التاريخية ، وقد يعده المنشائم بمثابة الداء

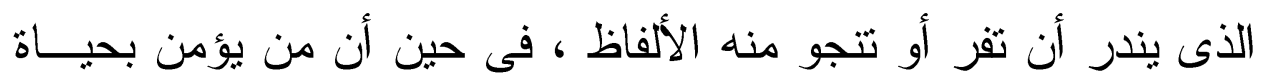

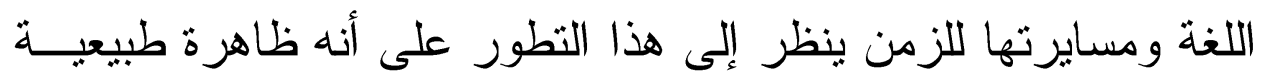

دعت إليها الضرورة الملحة (؟). عوامل التطور الدلالى : n

إذا بحثنا عن أسباب التطور الدلالى أو عوامله فإننا نراها ذات

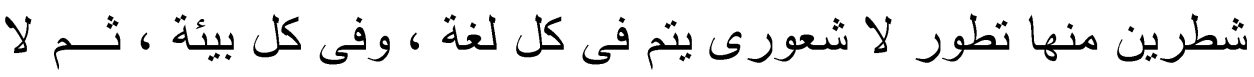

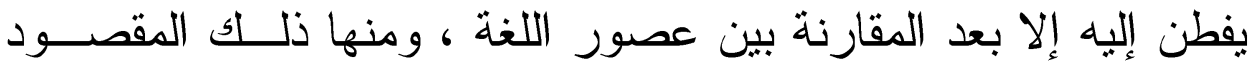

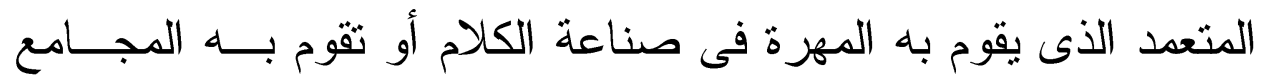

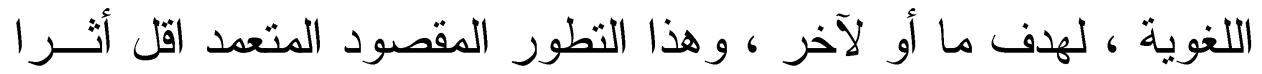
فى اللغات بوجه عام ، ويعد من تطور الطفرة فى دلالة الألفاظ ، ولذا قد نر اه فى الجيل الواحد من الناس ، ويشهـده المــرء خــلال حياتــهـ

() علم اللغة بين القديم والحـديث لأســاذنا الــكتور / عبـــالغفار هـلال صب اب طب

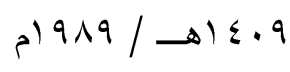

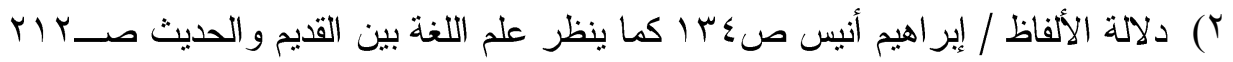




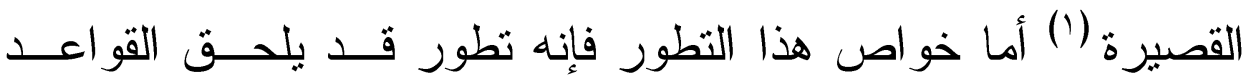
المتصلة بوظائف الكلمات ، وتزكيب الجمل ، وتلوين العبــار ات ، أو تطور يلحق الأسباب ، أو تطور يلحق معنى الكلمة نفسه(r) . اتجاهات التطور الالالى: يمكننا تلخيص هذه الاتجاهات فى أمور ثلاثة أولا : تعميم المعنى الخاص : وذلك عند الخروج من معنى خاص الى معنى عام ، ويتمثل فى كثير من الكلمات العربية الفصحى التى تطور معناها فكلمات الورد و المنيحة - و الر ائد كانت مستعمله قديما فى معان خاصة ثم انتقلت الى معنى أوسع مما عرف لها من قبل (r) ثانيا : تخصيص المعنى العام : وذلك عند الخروج من معنى عام الى معنى خاص مــن أمنلـــة

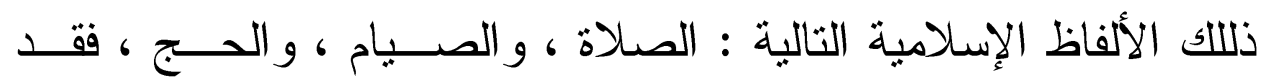
استعملت قبل ظهور الاسلام لمعان عامة ثم خصصها الإسلام بمجالات

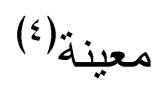

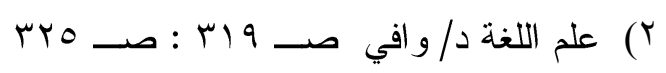

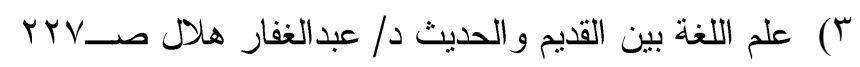
ع) السابق نفسه 
ثالثا : انتقال اللفظ من معنى الى آخر أجنبى عنه :

ينتقل اللفظ أحبانا الى معنى مغاير لمعناه القديم فيعد أجنبيا ويتم هذا فى إطار علاقة تسوغ الانتقال فليس معنى أنه عدم وجود مناسـبة لمعاية بين المعنيين ، ولكن اعتباره أجنبيا مبنى على عدم اثشتر اكها فى الفكرة

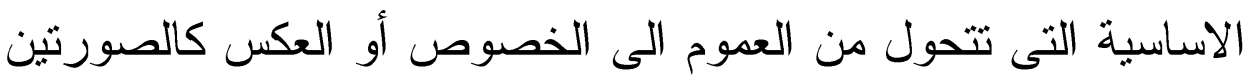

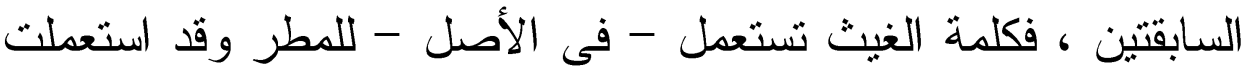

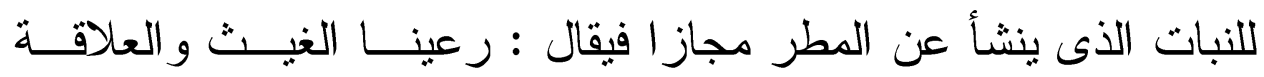
السبيية ، ومن ذلك الفاظ عربية كثثرة تحولت دلالتها وذكــر بعضــــها

فيما مضى (') (1) التظور الالامى فى " غريب القرآن " للسجستانى

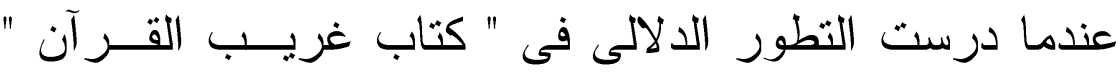

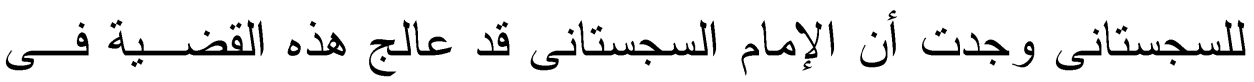

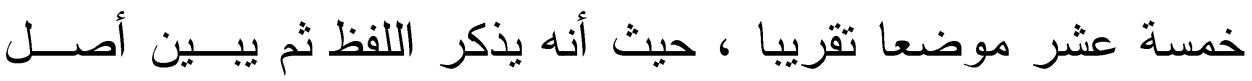

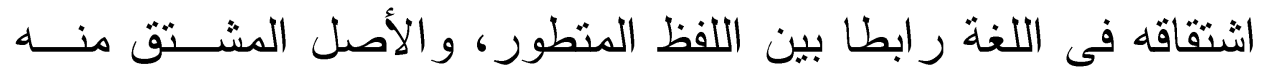

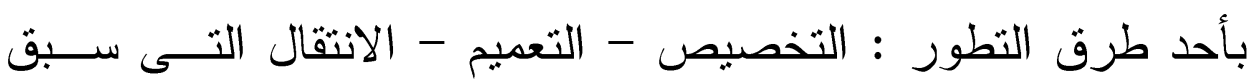
الحديث عنها ، و التى كان للإمام السجستانى فضل السبق إلبها ، كما كان له فضل السبق إلى غير ها فوجه هو وغيره من السابقين أنظار

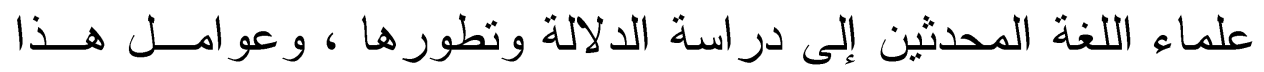
التطور ..... الخ اءك 


\section{أولا : تخصيص العام فى غريب القرآن للسجستانى}

ونقصد بتخصيص الدلالة : ما يلحق الكلمة من تطور بضــيق

فيه المعنى ويقلل من اتساع عمومه من ذللك :

أو لا : تعليقه على كلمة " قانت " من قوله تعالى " قانـــ آنــاء

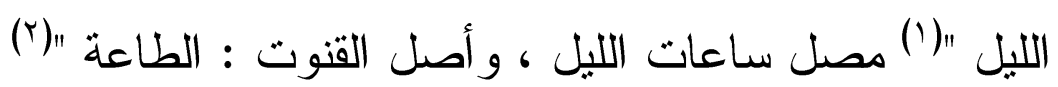

فقى قوله " أصل القنوت : الطاعة تعميم دلالة ، كمـــا أن فــى

قوله " قانت " أى مصل تخصيص من هذا العموم أى أنه المتطور عن له السابق فإذا ذهبنا إلى اللسان وجدناه يو اققه على ذلك حيــث يقــول " القنوت : الطاعة هذا هو الأصل ، ومنـــهـ قولـــهـ تعــالى " و القــانتين

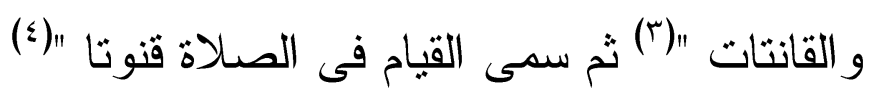

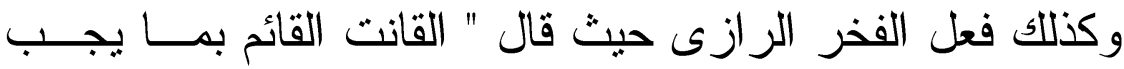

عليه من الطاعة ، ومنه قوله صلى الله عليه وسلم " أفضــلـل الصــلاة

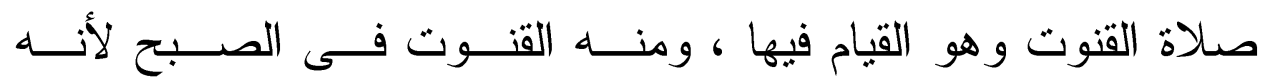
") بدعو قائما "(0)

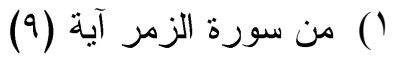

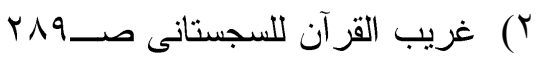

$$
\begin{aligned}
& \text { r) من سورة الأحز اب آية (ro) } \\
& \text { ع ) اللسان هن }
\end{aligned}
$$

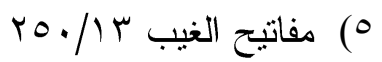




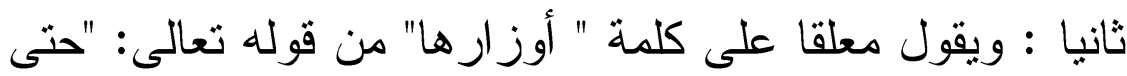

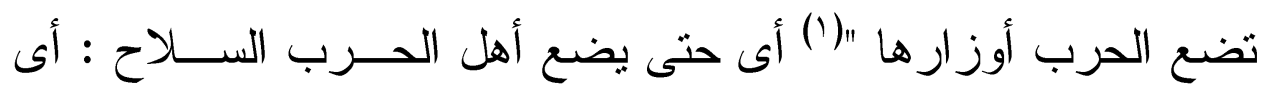

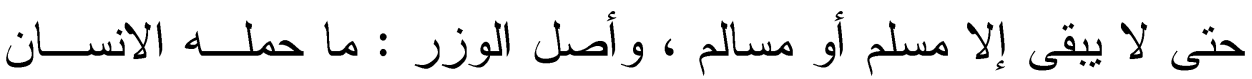

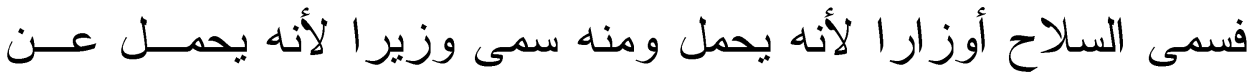

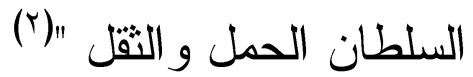

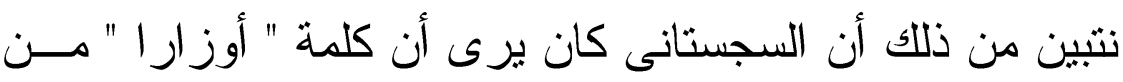

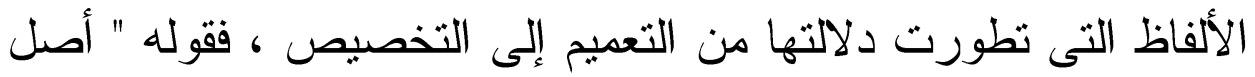

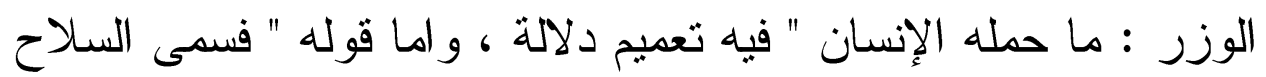

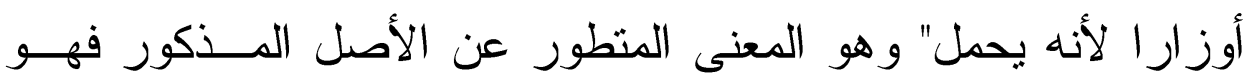
تخصيص للالالة السابقة .

وفى اللسان " الوزر : الحمل الثقيل ، و الوزر : الأنب لثقلــهـ،

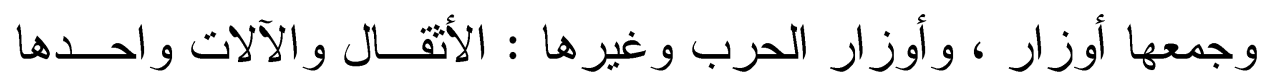

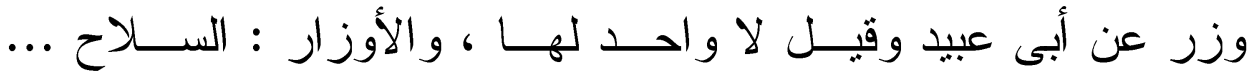
ووضعت الحرب أوز ارها" : أى أثقالها من آلة حرب ابل ، وسلاح و وغبره

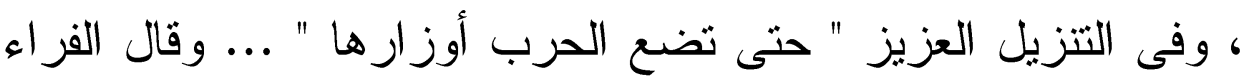

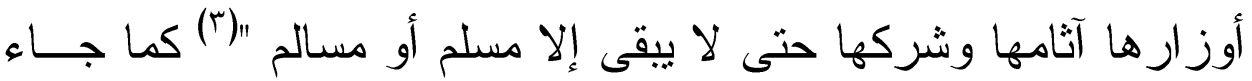

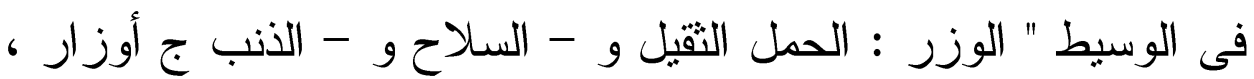
ويقال : أعدوا أوزار الحرب : آلاتها ، ووضعت العمل الحرب أوزارهـــا :

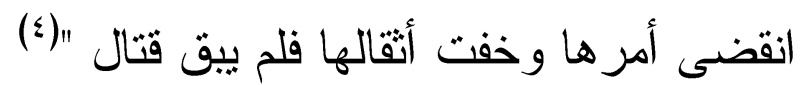

$$
\begin{aligned}
& \text { ( ) من سورة محمد آية (ع) (آل) }
\end{aligned}
$$

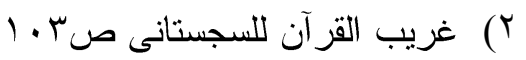

$$
\begin{aligned}
& \text { r) اللسان r^^/9 (وزر) } \\
& \text { ع) الوسيط صـV • ( (وزر) }
\end{aligned}
$$


ويتضح من هذا أن المعجمين " اللسان و الوسيط " قد ثو افقا على

أن المعنى اللغوى لكلمة " وزر " هو الحمل التقيل وهى دلالة عامــة ، كما تو افقا على أن الأوز ار قد تستعمل بمعنى الســلاح وهــى دلالـــة خاصة ويبقى للسجستانى فضل التصريح بالدلالتين العامة و " الخاصة" المتطورة عن العامة .

ثانيا : تعميم الخاص فى غريب القرآن للسجستانى يقصد بتعميم الخاص : الخروج من معنى خاص الى معنى عام من ذلك :-

1- قوله معلقا على كلمة " يتدبرون " من قوله تعالى " يتدبرون

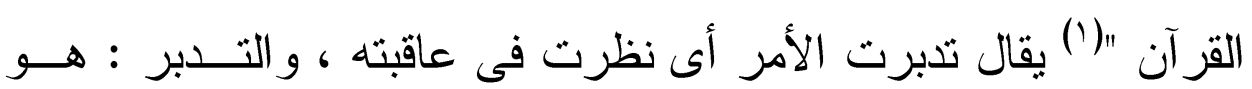
قيس دبر الكلام بقبله لينظر هل يختلف ، ثم جعل كل تمبيز تدبرا "(r) فالمعنى الخاص لكلمة " التدبر " هو " النظر فى عو اقب الأمور "و أما المعنى العام المتطور عنه فهو أنه أصبح بطلق على كل تمييـز تدبر ا ، فإذا ذهبنا الى الصحاح وجدناه يقول " التدبير فـى الأهــر أن

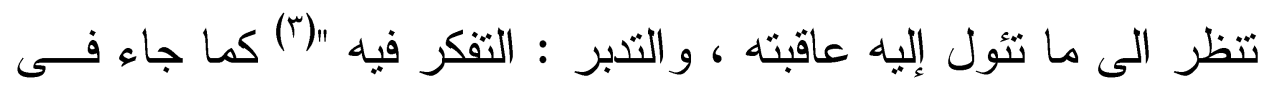
اللسان " دبر الأمر وتدبره : نظر فى عاقبته ، و اســتدبره : رأى فـى عاقبته مالم برى فى صدره ، وعرف الأهـر تـدبر أى بــــرة ... .

$$
\begin{aligned}
& \text { ( ) من سورة محمد آية(Y) (T) }
\end{aligned}
$$

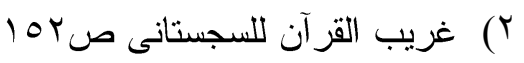

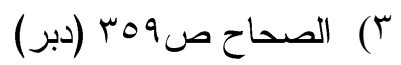


و التدبير فى الأمر أن تتظر إلى ما تثئول إلبه عاقبته ، و التدبر : التفكر

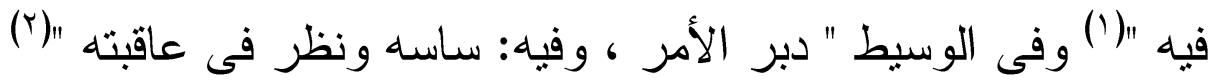

نلاحظ أن هذه المعاجم الثناثة قد حددت المعنى اللغوى لكلمة "

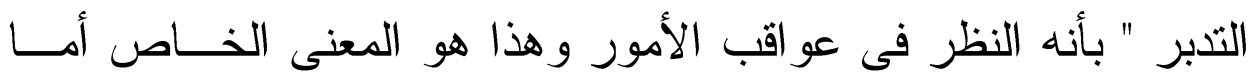

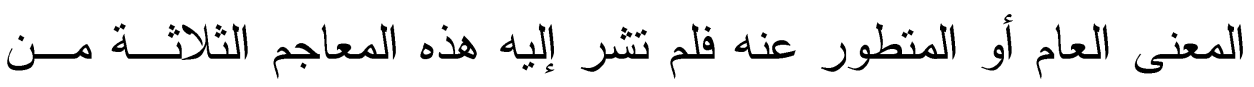

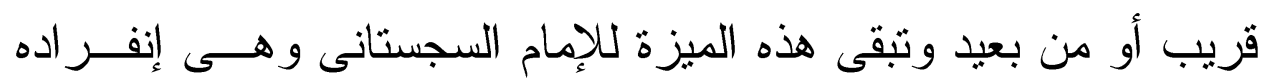
بذكر المعنى العام المتطور عن السابق.

r- ويقول معلقا على كلمة " زخرف " من قوله تعالى "زخرف

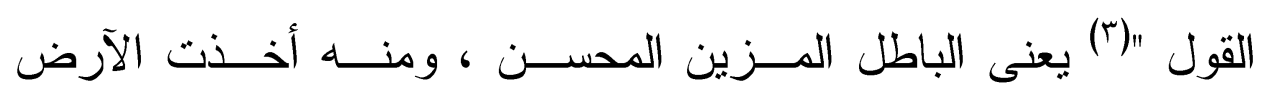

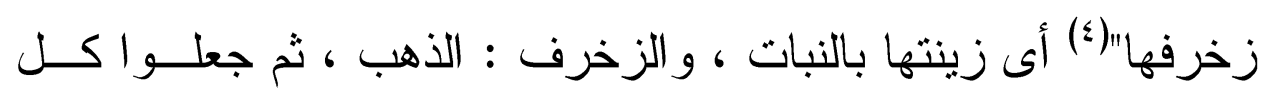

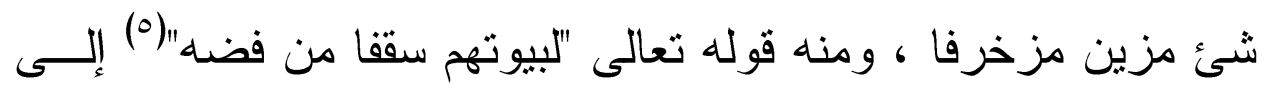

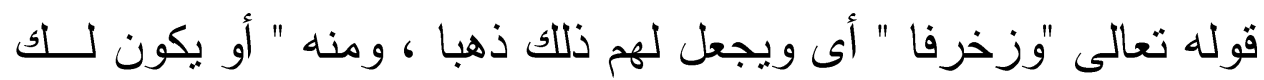

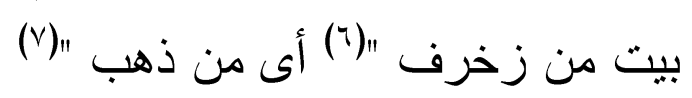

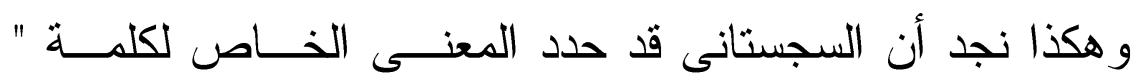

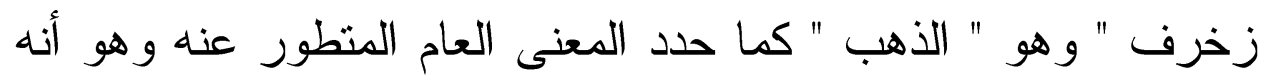

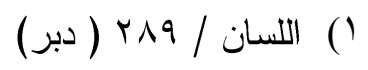

$$
\begin{aligned}
& \text { r }
\end{aligned}
$$

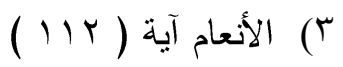

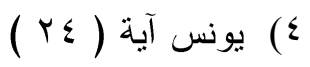

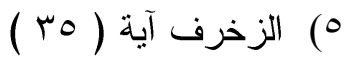

$$
\begin{aligned}
& \text { 7) الإسراء آية ( ب (9 ) }
\end{aligned}
$$

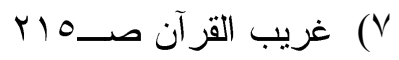




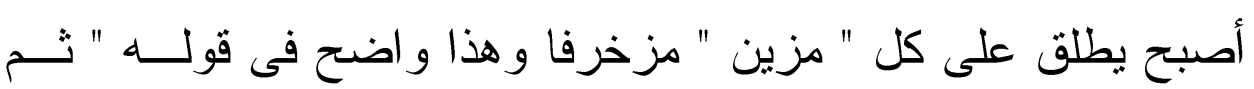

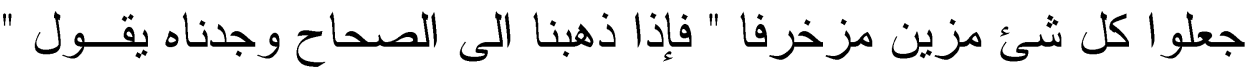

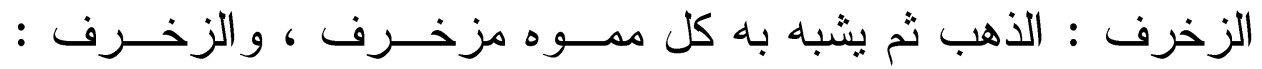

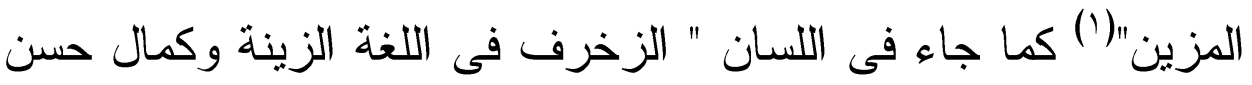

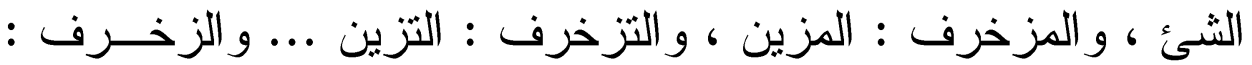

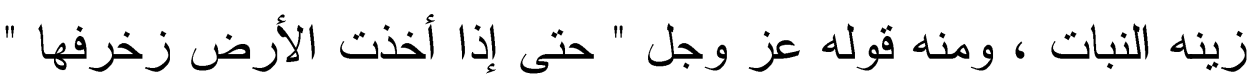

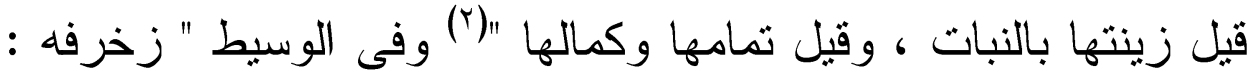

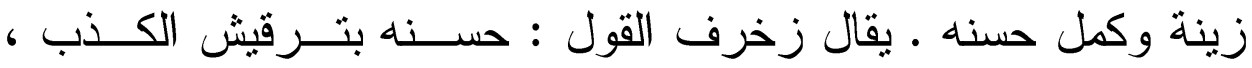
تزخرف : تزين ... و الزخرف : الذهب و الزينة وكمال حسن الثئ ، وزخرف الأرض : ألو ان نباتها "(") : الزخرف

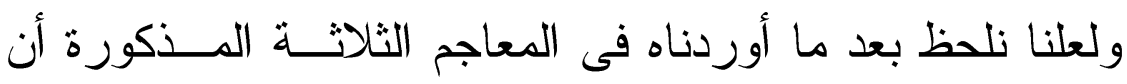

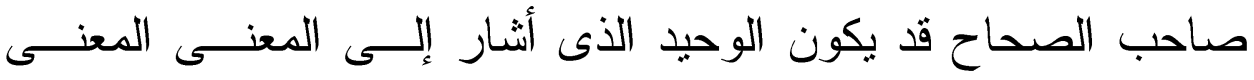
الأصلى لكلمة : زخرف وذلك فى قوله : الزخرف " الذهب كما أثنار

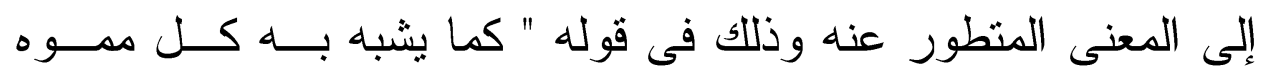

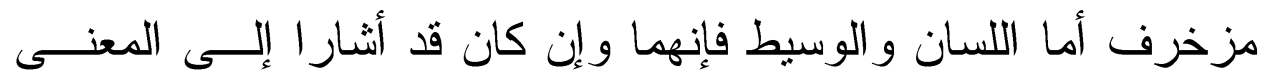

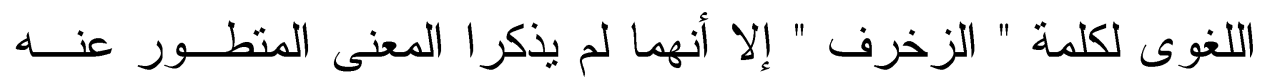

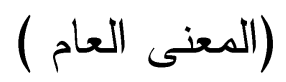

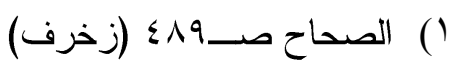

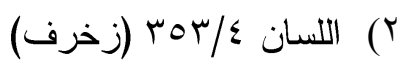

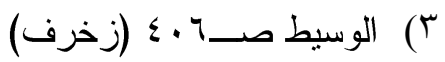


ب- كما يقول " الأسباب "(') الوصلات ، الو احد سبب ووصلة ، و أصل السبب الحبل يشد بالشئ فيجذب به ، ثم جعل كل ماجر شــيئا

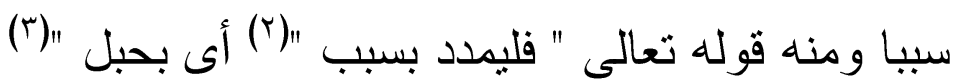
تبين من ذلك أن السجستانى كان يرى أن كلمة " الأسباب " من الألفاظ التى تطورت دلالتها من التخصيص إلى التعميم حيــث قــال " أصل السبب الحبل " فهذه هى الدلالة الأصلية لكلمة " ســبب " وهــى دلالة خاصة ، أما قوله " ثم جعل كل ماجر شيئا سببا " فهـى الدلالـــة

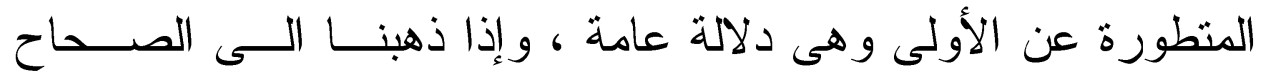
وجدناه يقول " السبب : الحبل ، و السبب أيضا كل شئ يتوصل به إلى غيره ، و السبب : اعتلاق قرابة "(؛) كما جاء فى مفاتيح الغيب " أصل السبب فى اللغة : الحبل قالو ا ولا يدعى الحبل سببا حتى ينزل ويصعد بها ، ومنه قوله تعالى " فليمدد بسبب إلى السماء " ثم قيل لكـلـ شــــ

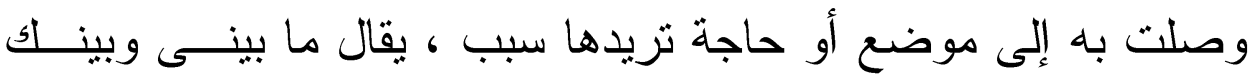
سبب أى رحم ودودة ، وقيل للطريق سبب لأنه بسلوكه تصــل إلـى الموضـع الذى تريده فال تعالى " فأتبع سببا " أى طربقــا ، وأســباب السموات أبو ابها لأن الوصول إلى السماء يكون بدخولها قـال تعــالى مخبرا عن فرعون " لعلى أبلغ الأسباب أسباب السموات قال زهير :

$$
\begin{aligned}
& \text { () من سورة البقرة آية (ד7 (1) } \\
& \text { r) من سورة الحج آية (10) }
\end{aligned}
$$

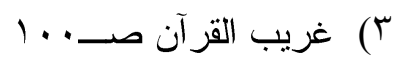

$$
\begin{aligned}
& \text { ع) الصحاح "سبب" عربب لعزن }
\end{aligned}
$$




\section{ومن هاب أسباب المنايا تناله .. ولورام أسباب السماء بسلم}

\section{و المودة بين القوم تسمى سلما لأنهم بها يتو اصلون"(')}

نتبين من ذلك أن كلا من الجوهرى والرازى قد تو افقا على أن

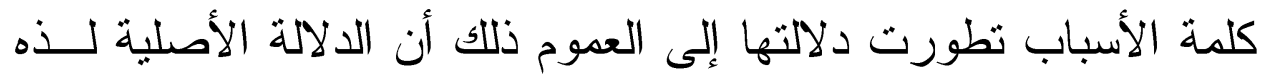

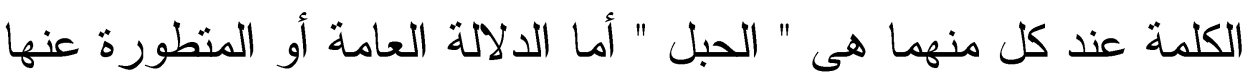

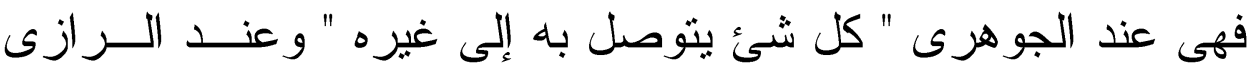

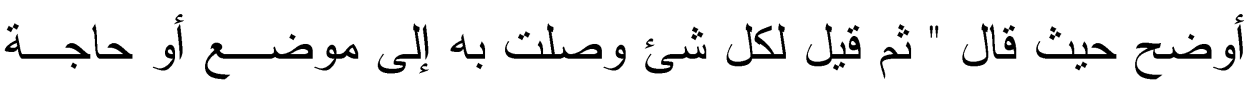
تريدها سبب " ومعنى ذلك أنهما قد تو افقا مع السجستانى على الدلالـــة الخاصة ، وكذا الدلالة العامة أو (المتطورة عنها).

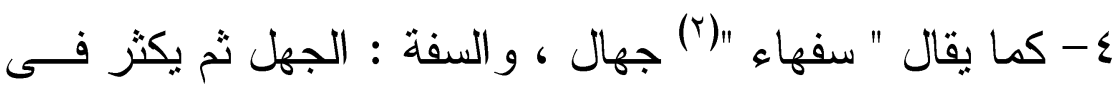
كل شئ ، يقال للكافر سفيه كقوله تعالى " سيقول السفهاء من النــاس "

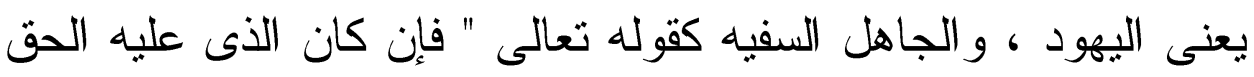

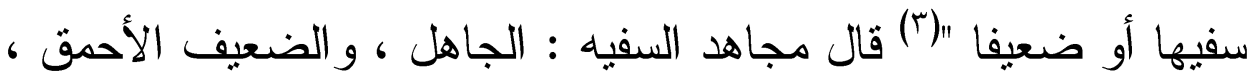
ويقال للنساء و الصبيان : سفهاء لجهلهم كقوله تعالى "و لا تؤنتو السفهاء

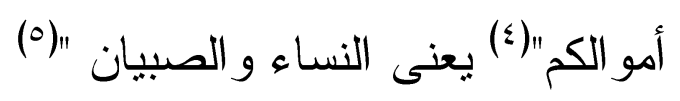

كما يرى السجستانى أن كلمة " سفيه " من الألفاظ التى تطــورت

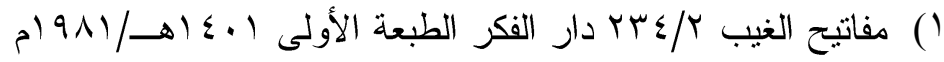

$$
\begin{aligned}
& \text { r }
\end{aligned}
$$

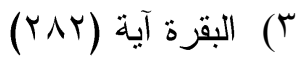

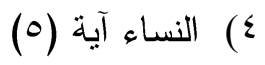

$$
\begin{aligned}
& \text { 0) غريب القرآن صPro (0) }
\end{aligned}
$$


دلالتها بالتعميم فأصل السفه - عنده - الجهل ثم أصــبح عامـــأفــــح

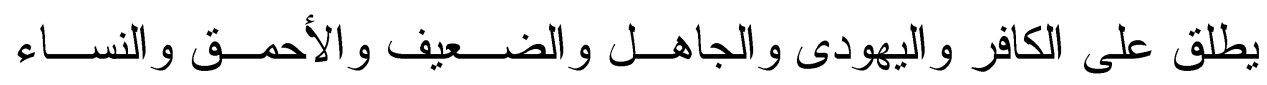

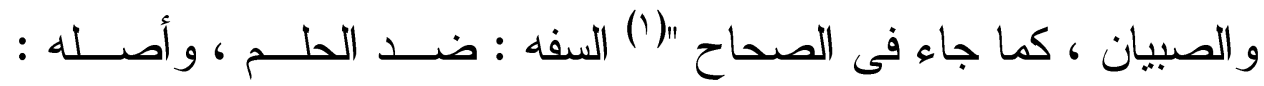
الخفة ، يقال تسفهت الريح الثجر : أى مالت بها... وسفهه تسفيها : نسبه

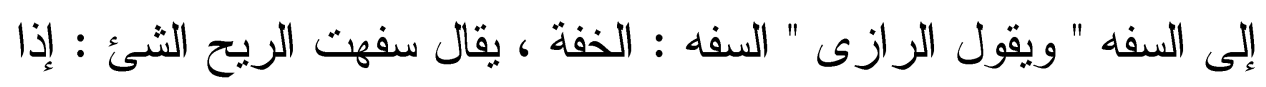

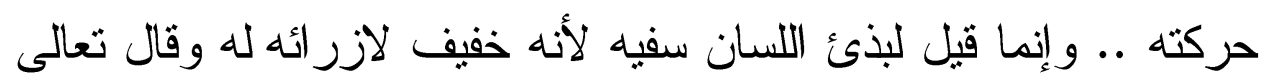

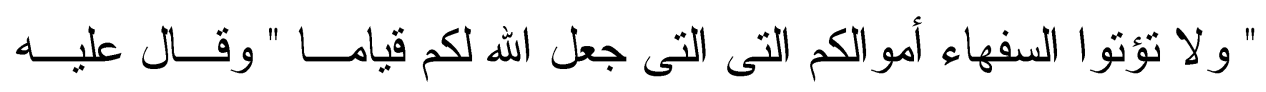

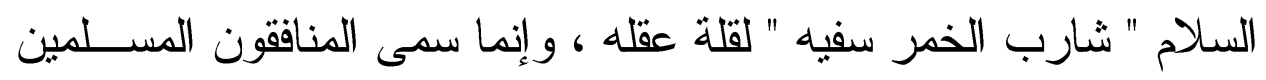

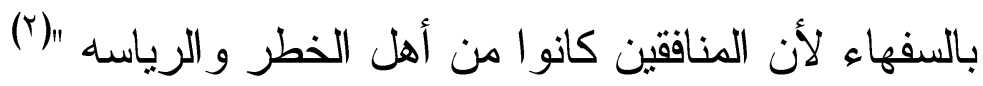
وهكذا نجد أن كلا من الجوهرى و الرازى وإن كانا قـــ حــددا

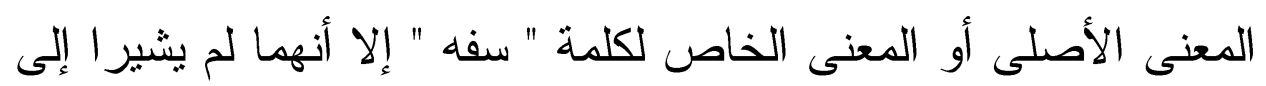

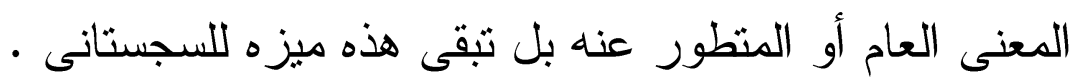
ه- ويقول السجستانى "مفلحون"(") الفلاح : البقاء و الظفر أيضا

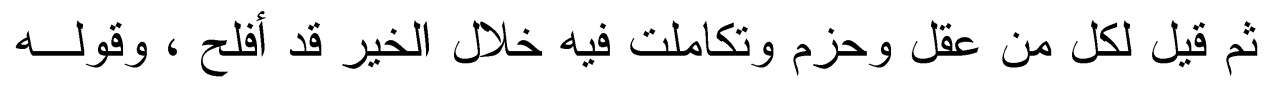

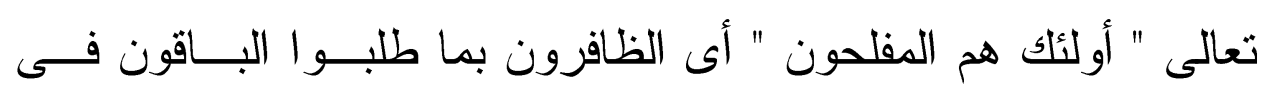

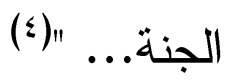

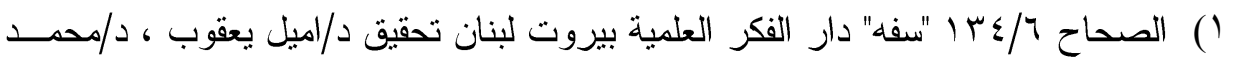

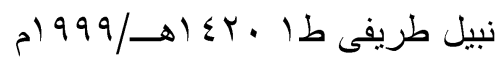
Vo/r الغيب (ا) البقرة آية (ب) ع) غريب القرآن صــr (0) 
نتبين من ذلك أن السجستانى كان يرى أن كلمة " الفلاح " مــن

الألفاظ التى تطورت دلالتها من الخصوص إلى العموم فأصل الفلاح :

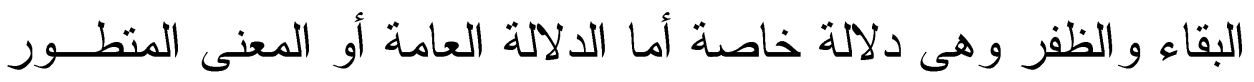

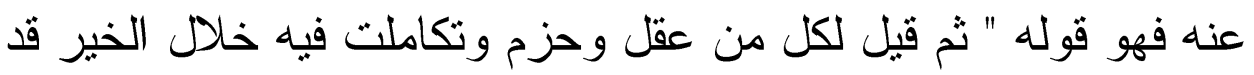

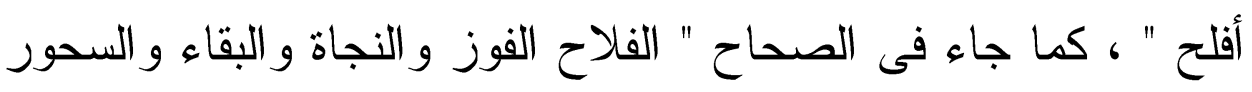

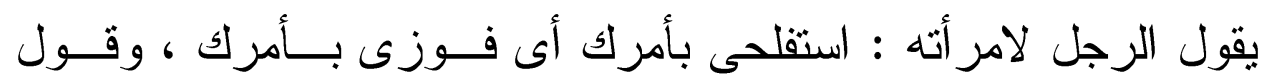
الشاعر : ولكن ليس للدنيا فلاح.

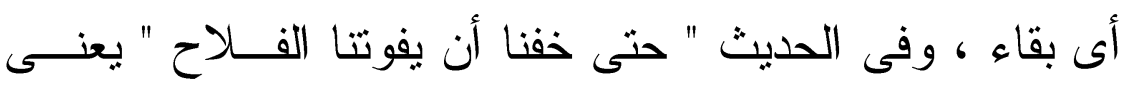

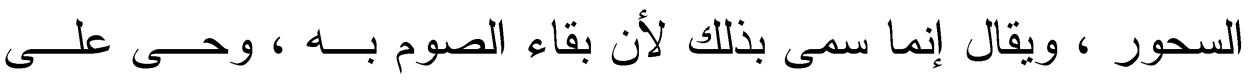

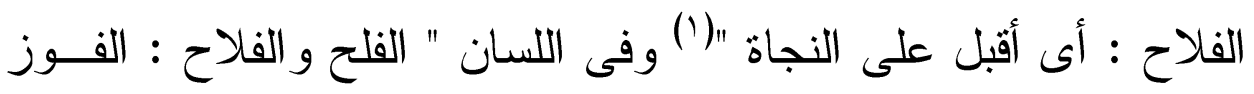

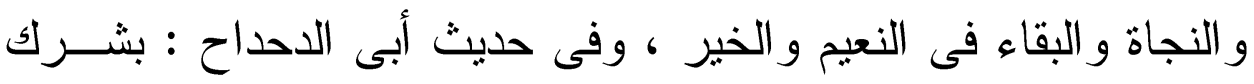

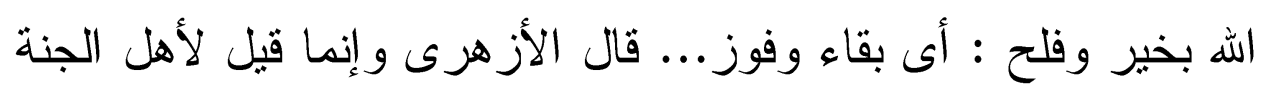

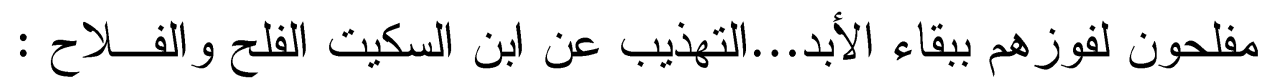

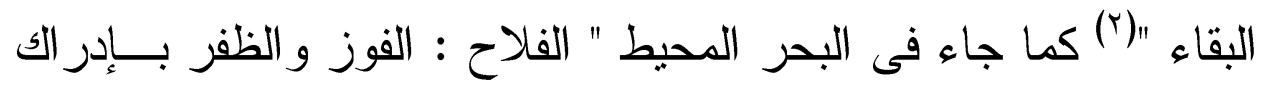

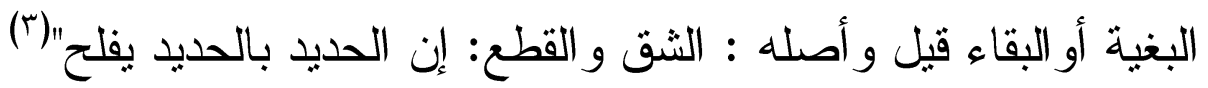

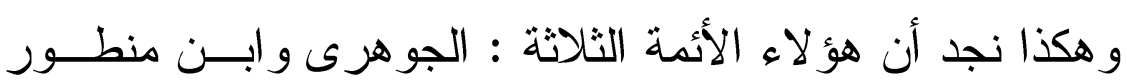

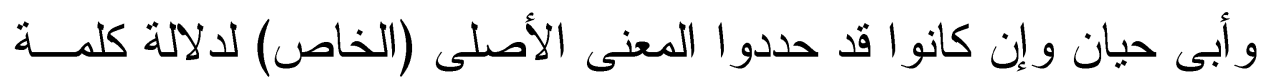

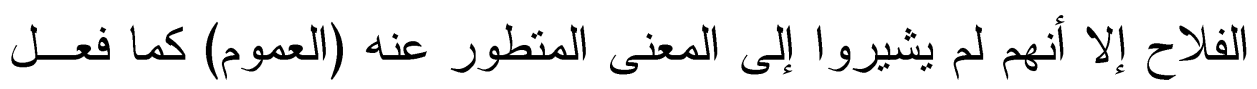

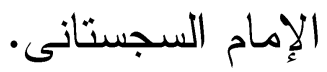

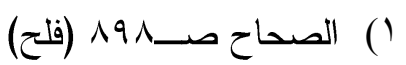
100/V اللسان (Y) 191// البحر المحيط 
צ- كما يقول " مناسكنا "(") متعبداتتا ، و احدها منسك ومنسك ، و أصل النسك من الذبح ، يقال نسكت : أى ذبحت ، و النسيكة : الذبيحة المتقرب بها إلى الله تعالى ثم اتسعو ا فيه حتى جعلوه لمو اضع العبــادة

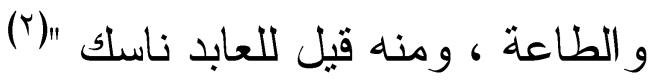

كذلك يرى السجستانى أن كلمة منسك من الكلمات التى تطورت

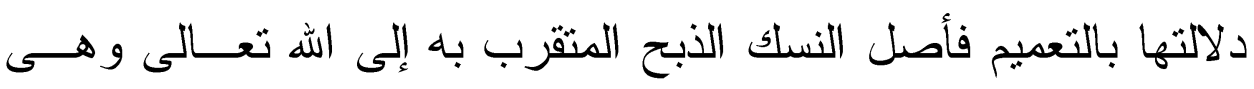

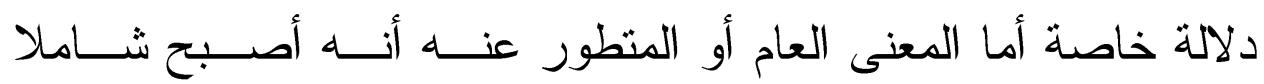
لمو اضع العبادة و الطاعة فإذا ذهبنا إلى اللسان:وجدناه يقول "فى التنويل

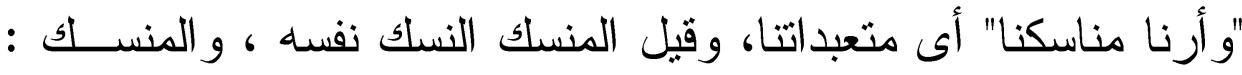
الموضع الذى تذبح فيه النسيكة و النسائكل... ويقال إن لفــلان منســكا

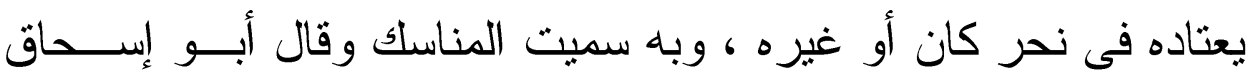

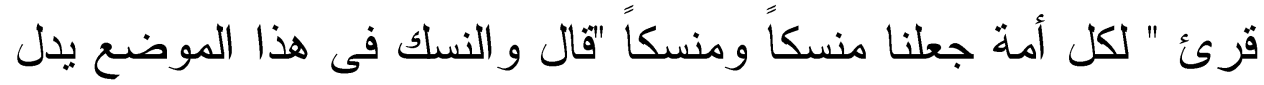
على معنى النحر كأنه قال جعلنا لكل أمة أن تثقرب بأن تذبح الــذبائح

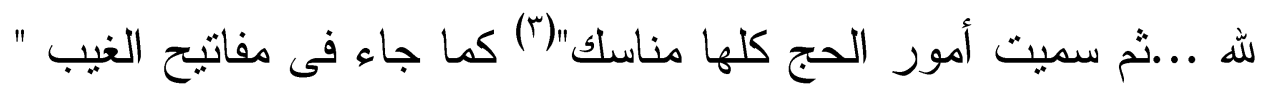

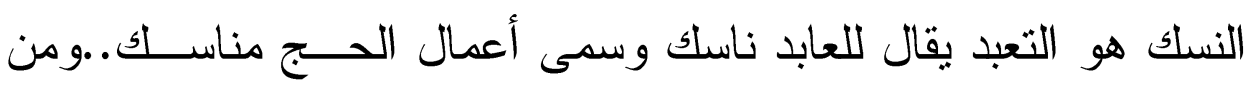
المفسرين من حمل المناسك على الذبيحة فقط وهو خطأ... و إن حملنـا

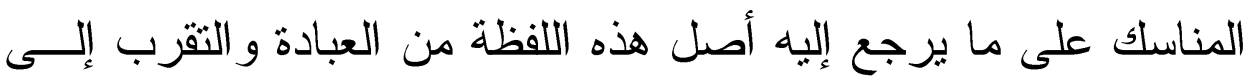

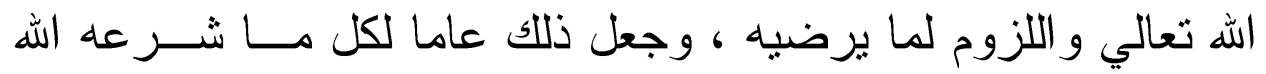

$$
\begin{aligned}
& \text { ( ) البقرة آية (Y) } \\
& \text { r }
\end{aligned}
$$

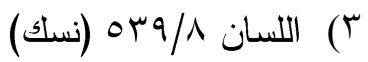




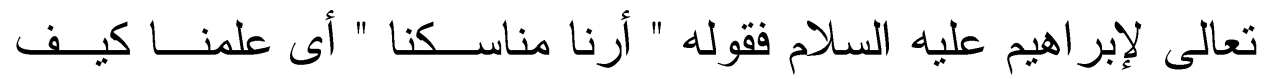

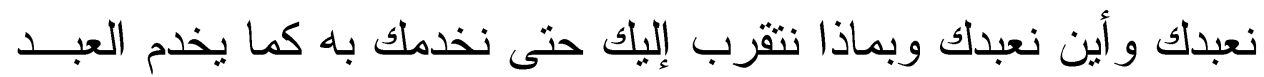
(1)" (1) مو لان

يتضح من هذا أن صاحب اللسان و إن كان قــد حــد المعنـى

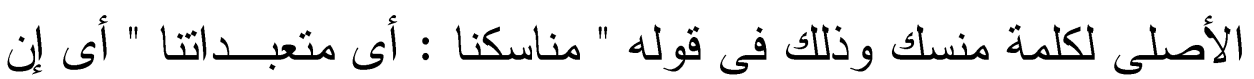

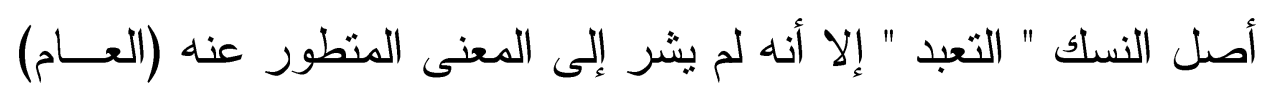

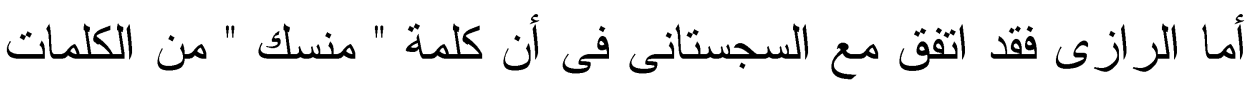

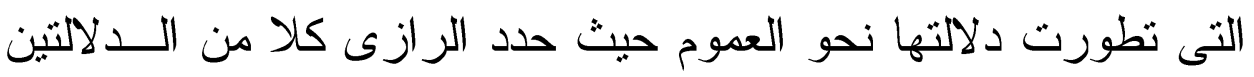

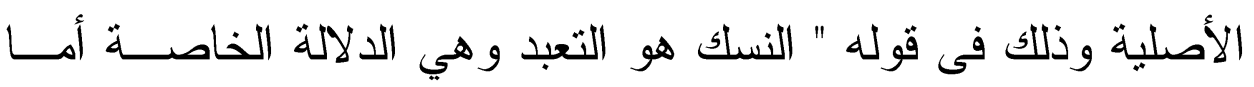

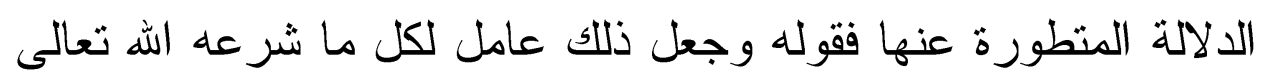
لإبر اهيم عليه السلام " وهى الدلالة العامة . ثالثا : تطور الدلاية عن طريق الاتقال عند السجستانى ويقصد به الانتقال بالكلمة من معناها الأصلى إلى معنى آخــر

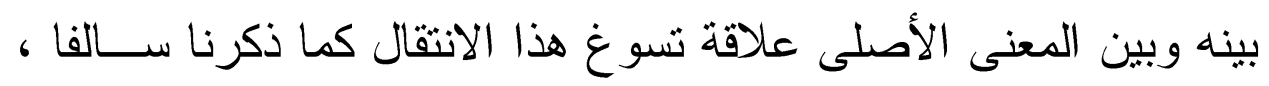

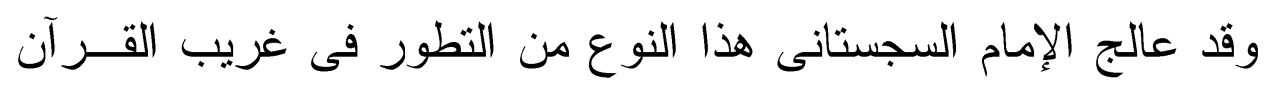
من ذلك قوله :

1- "حنيف"(ז) من كان على دين إبر اهيم عليه السلام ، ثم سمى

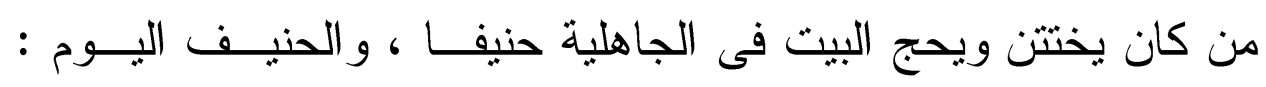

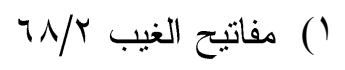

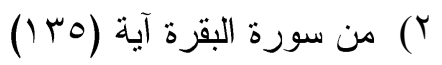


المسلم ، وقبل إنما سمى إبر اهيم عليه السلام حنيفا لأنه حنف عما كان

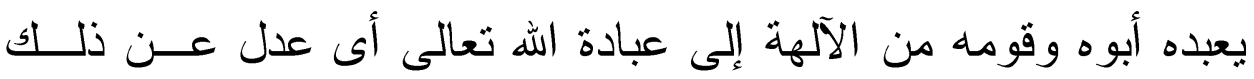

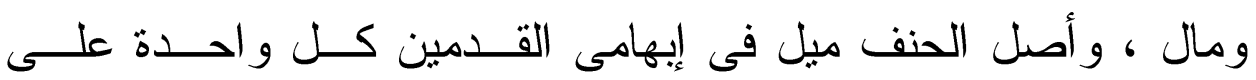

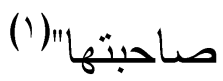
يشير السجستانى إلى أن كلمة " حنبفا " مــن الكلمـات التـى

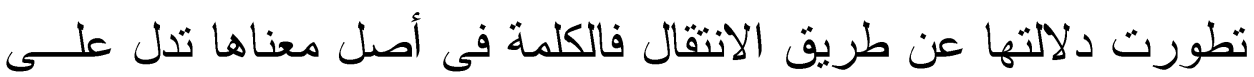
ميل فى إبهامى القدمين كل واحدة على صاحبتها ثم استعملت - عـن فئن طريق المجاز - فى الجاهلية للالالة على من كان يختنـ ويحج البيــــ أما فى الاسلام فقد سمى المسلم " حنيفا "

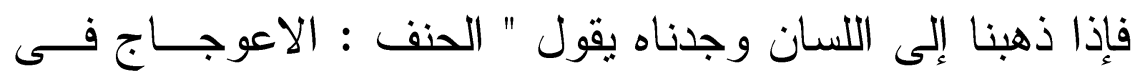
الرجل وهو أن تقبل إحدى إبهامى رجليه على الأخرى ، وفى الحديث

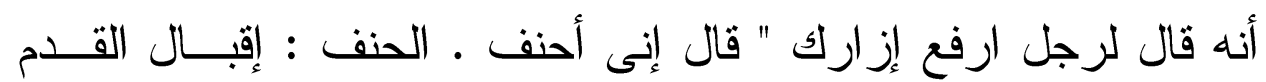

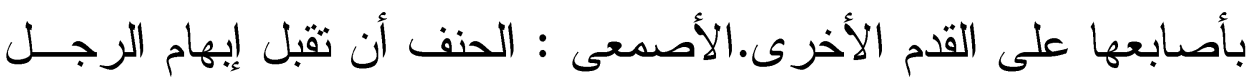

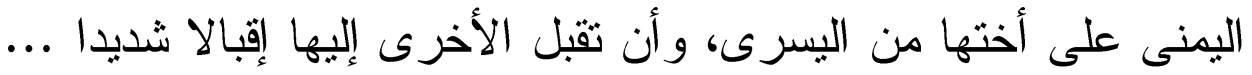
وحنف عن الثئ وتحنف : مال ، و الحنيف : المسلم الذى يتحنف عـن لـن الأديان أى يمبل إلى الحق ... وقال الأخفش : الحنيف المسلم ، وكــان

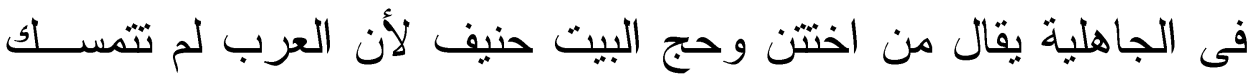
فى الجاهلية بشئ من دين إبر اهيم غير الختان وحج البيت فكـلـل مــن

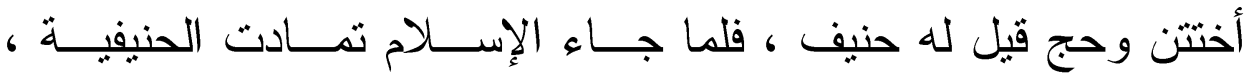


فالحنيف المسلم ... ومعنى الحنيفية فى اللغة : الميـلـل ، و المعنــى أن

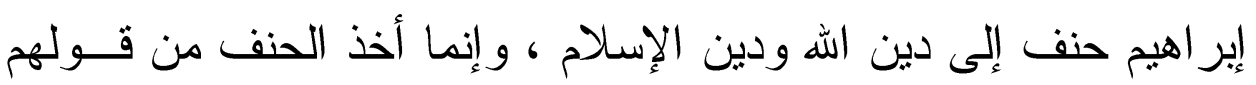
رجل أحنف ورجل حنفاء ، وهو الذى تميل قدماه كل واحدة إلى أختها

(1)" بأصابعها

كما جاء فى البحر المحيط " الحنف : لغة الميـل وبــهـ ســى الأحنف لميل كان فى إحدى قدميه عن الأخرى فال الشاعر :

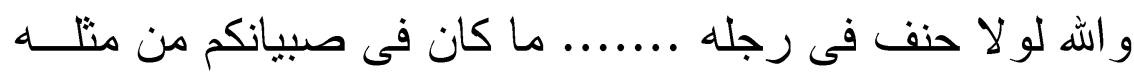

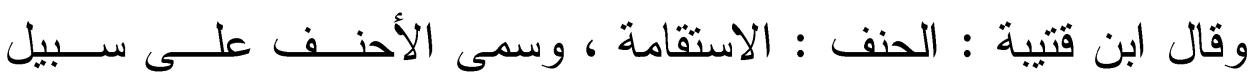

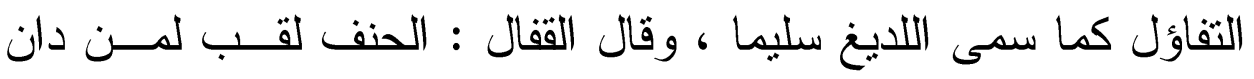
الإسلام كسائر ألقاب الديانات وقال عمر :

حمدت الله حين هدى فؤادى ... إلى الاسلام والدين الحنيف "(r) نفهم مما أوردناه عند كل من ابن منظور و أبى حيــان أن ابـن أبـن

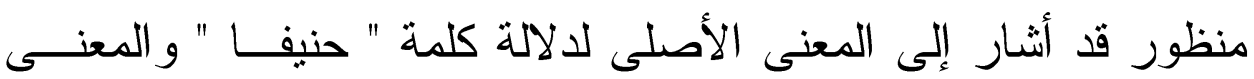

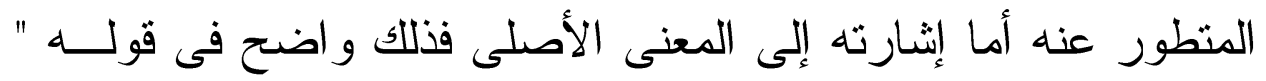

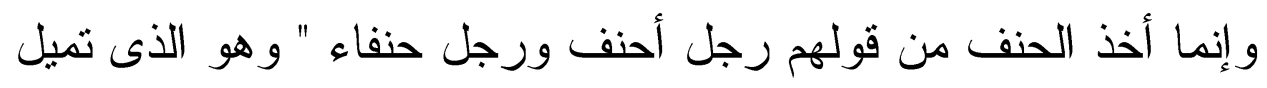

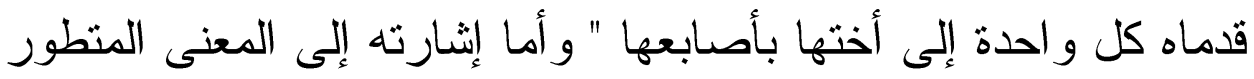

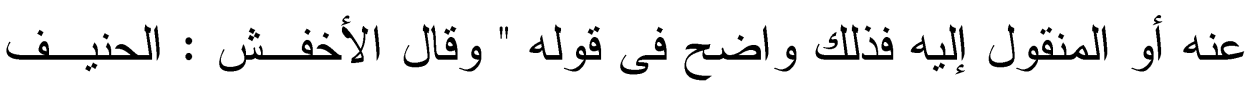
المسلم ، وكان فى الجاهلية يقال من أختنن وحج البيت فهو حنيف ولأن وهل

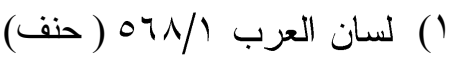

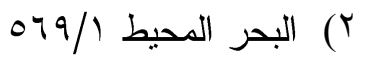


العرب لم نتمسك فى الجاهلية بشئ من دين إبر اهيم غير الختان وحـــج البيت فكل من اختن وحج قيل له حنيف فهو بهذا يتفق مع السجستانى فى إثتارته إلى الدلالة الأصلية وكذا الدلالة المتطورة عنها ، أمـا أبــو حيان فإنه و إن كان قد ذكر المعنى الأصلى أو اللغوى لهذه الكلمــة إلا أنه لم يشر من قريب أو بعيد إلى الدلالة المتطورة عنها .

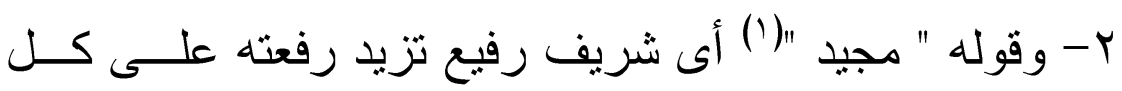
رفعة وشرفه على كل شرف من قولك : أمجد الدابة علفا : أى أكثــر وزد "(r) كما يشير السجستانى هنا إلى أن كلمة " مجيد " من الكلمــات التى تطورت دلالتها عن طريق الانتقال فهذه الكلمة فى أصل وضعها كانت تستعمل بمعنى الدلالة على " امتلاء بطن الدابة بــالعلف " أمــــا الالالة المتطورة عنها عن طريق الانتقال فهـى امــتلاء الموصــوف بالصفات الحمبدة لعلاقة المشابهة بين المعنيين المعنى الأصلى و المعنى

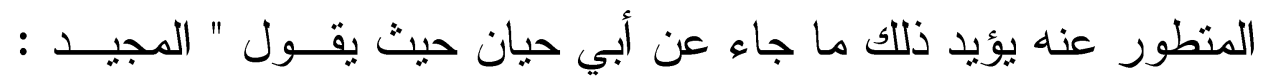
قال ابن الأعرابى : الرفيع يقال مجد يمجد مجدا ومجادة ومجد لغتان : أى كرم وشرف و أصله من قولهم : مجدت الإبل تمجد مجدا شـبـعت ، وقال : أمجدث الدابة : أكثرث علفها وقال أبوحيه النميرى : تزيد على صواحبها وليست .... بماجدة الطعام ولا الثراب أى ليست بكثرة الطعام ولا الثراب ، وقال الليث أمجد فــلان 
عطاءه ومجده : إذا أكثره ، ومن أمثالهم فى كل شجر نار ، و واســتمد

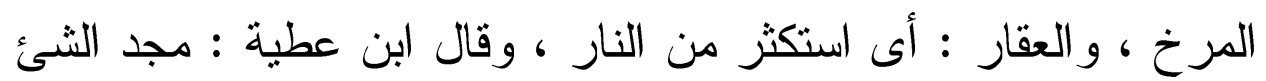
إذا حسنت أوصافه "(1)

و هكذا نجد أن أباحيان يو افق السجستانى على أن كلمة " مجيد "

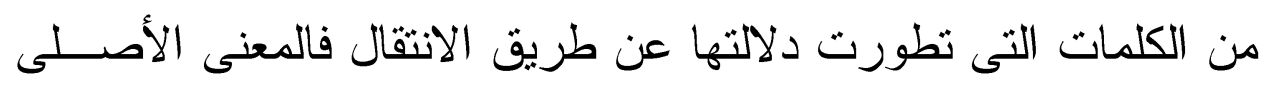

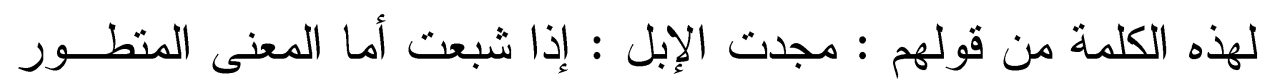

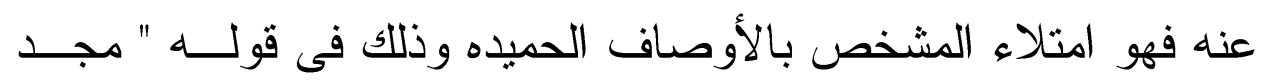

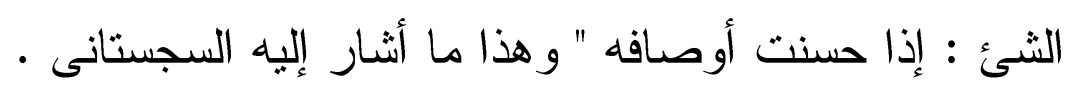
ب- وقوله " حواريون "(؟) صفوة الأنبياء عليهم الســلام الــذين خلصو ا وأخلصوا فى التصديق بهم ، ونصرتهم ، وقيل إنهـم كــانوا

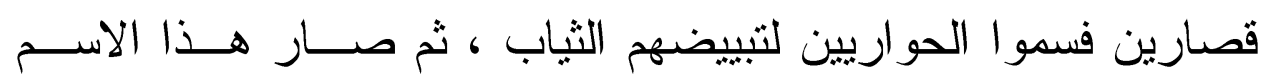
مستعملا فيمن أشبهره من المصدقين وقيل كانو ا صيادين ، وقيل كانوا

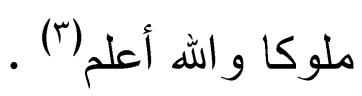

يشير السجستانى أيضا إلى أن كلمة " حو اريين " من الكلمـات

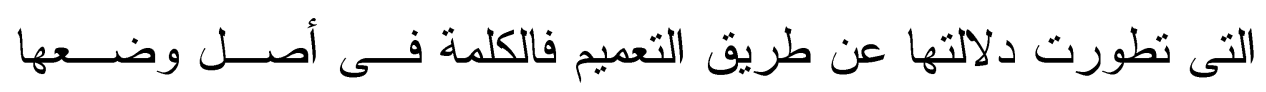

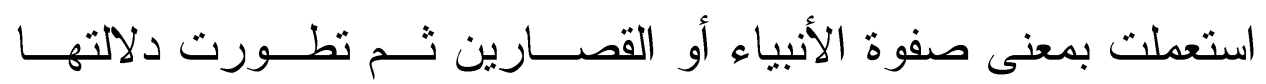
فأصبحت تدل على كل من أشبههم من المصدقين وغبرهم ، يدعمه ما باء

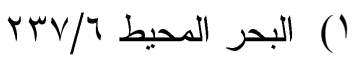

$$
\begin{aligned}
& \text { r } \\
& \text { r) غريب القرآن صـ }
\end{aligned}
$$


جاء فى اللسـان " التحـــوير : التيـــضض : والحواريــون القصـــارون لتبيضييهم لأنهم كانو ا قصارين ، ثم غلب حتى صسار كل ناصر وكـلـ حميم حواريا "(ا) فإذا ذهبنا إلى أبي حيان وجدناه يقول " الحــوارى : صفوة الرجل وخاصته ، ومنه قيل الحضريات : الحواريات لخلــوص ألو انهن ونظاقتهن قال أبو جلدة اليشكرى :

فقل للحواريات يبكين غيرنا ... ولا تبكنا إلا الكلاب النوابح

ومثله في الوزن الحو الى للكثير الحيلة،ولبست الباء فبهما للنسب

وهو مشتق من الحور وهو البياض حورت الثوب:بيضته"(r)

نتبين من هذا أن صاحب اللسان قد ثوافق مع السجستانى علـى أن كلمة " الحواريين " من الكلمات التى تطورت دلالتها من الخصوص هن

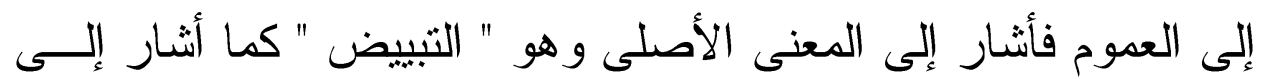

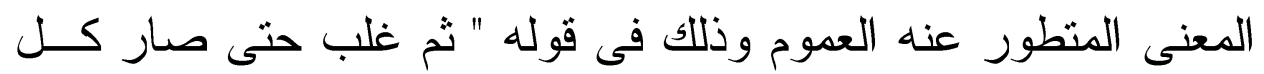
ناصر وكل حميم حواريا " أما أبوحيان فإنه و إن كان قد حدد المعنـى الأصلى لهذه الكلمة إلا أنه لم يتعرض للمعنى المتطور عنه كما نرى . ع- وقوله " ذنوب "(r) نصيب و أصل الذنوب الدلو العظيمـــة ،

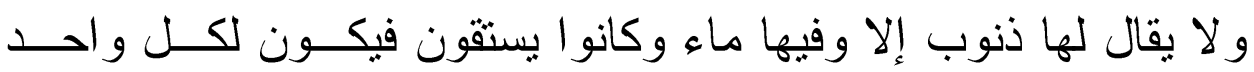
ذنوب فجعل الذنوب في مكان النصيب "(؛)

$$
\begin{aligned}
& \text { ( ) اللسان r/r } 1 \text { (حور) }
\end{aligned}
$$

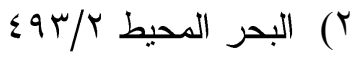

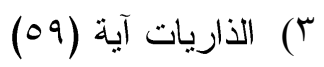

$$
\begin{aligned}
& \text { ؟) غريب القرآن صـ } 199
\end{aligned}
$$


و هكذا نجد أن السجستانى يرى أن لفظ " ذنوب " من الألفاظ التـى

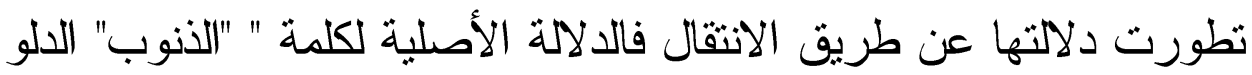

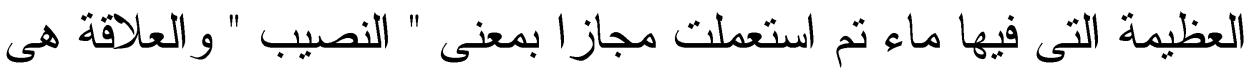
المشابهة بين المعنى الأصلى و المعنى المتطور عنه ، يؤيد ذلك ويدعمــهـ ما جاء فى كل من اللسان و المحرر الوجيز فقى اللسان " التهذيب الذنوب النه فى كلام العرب على وجوه من ذللك قوله تعالى " فإن للذين ظلمو اذنوبــا

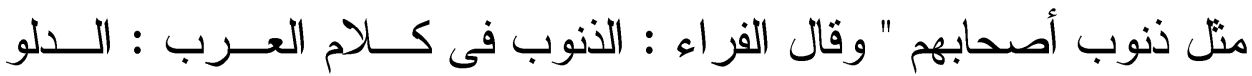

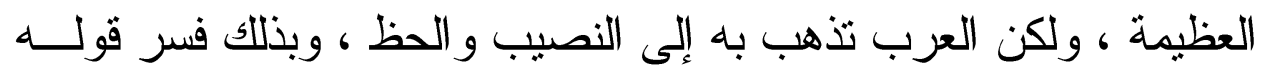

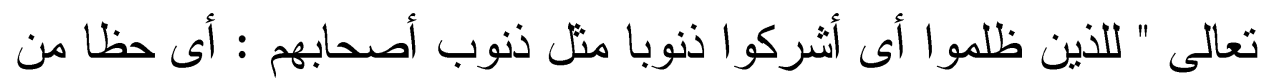

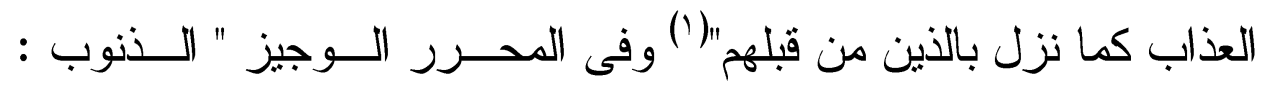

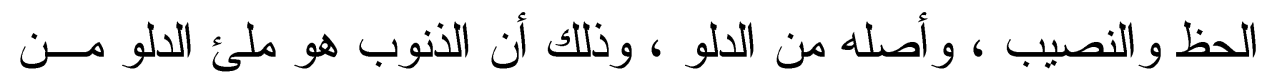
الماء ، وقيل الذنوب الدلو العظيمة ، ومنه قول الثاعر :

\section{إنا إذا نازلنـا غريب

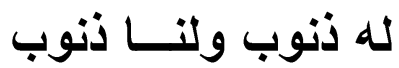 \\ فإن أبيتم فلنــا القليب}

وهو السجل .... " " (ץ)

نتبين من ذللك أن كلا من ابن منظور وابن عطية قد تو افقا مــع

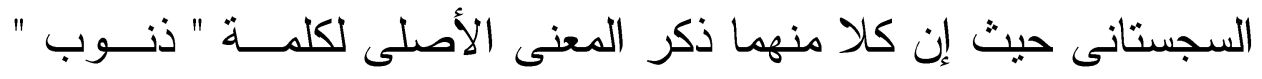

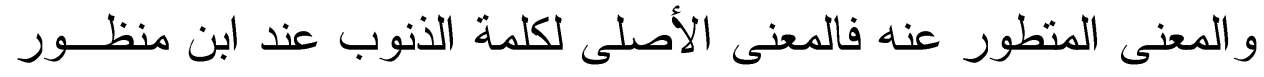

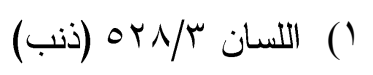

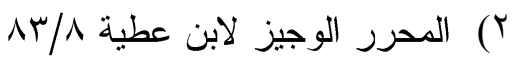


يتضح فى قوله " الذنوب فى كلام العرب : الدلو العظيمة " و أما المعنى

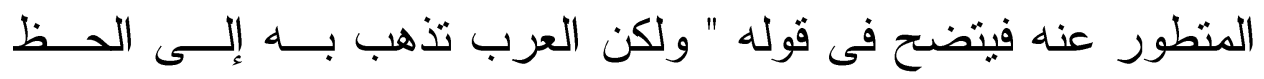
و النصيب " كما يتضح المعنى الأصلى فى قول ابن عطية " الــنـوب :

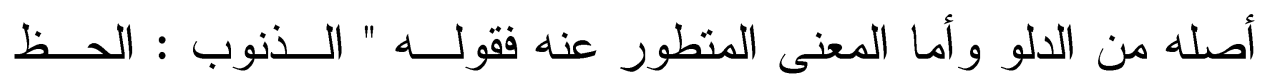

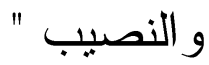

0- ويقول " غائط "(1) مطمئن من الأرض ، وكــانو ا إذا أر ادوا

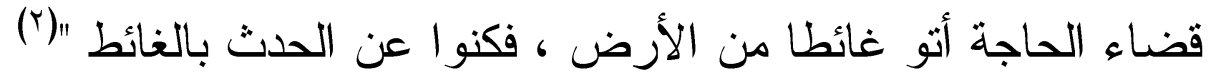
كذلك من الألفاظ التى تطورت دلالتها عن طريق الانتقال كلمة

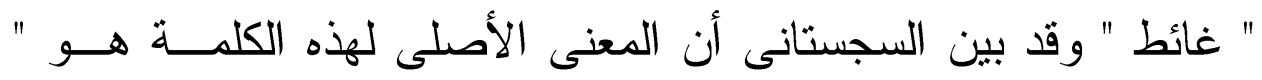

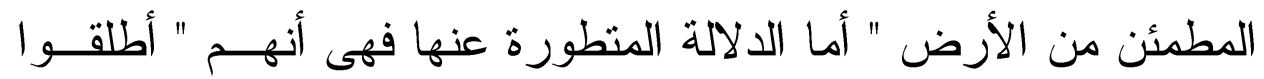
على الحدث غائطا " يؤيد ذلك ويقويه ما جاء فى كل من البحر المحيط

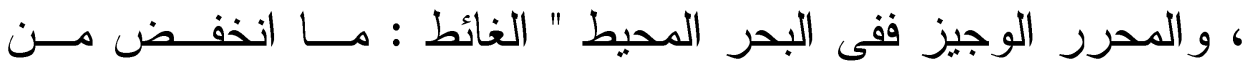

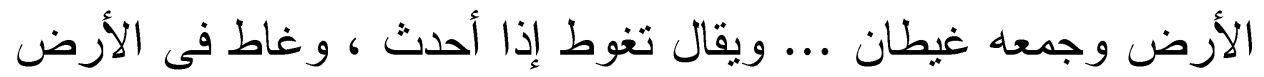
يغيط ويغوط غاب فيها حتى لا يظهر إلا لمن وقهـف عليــهـ ، وكــان

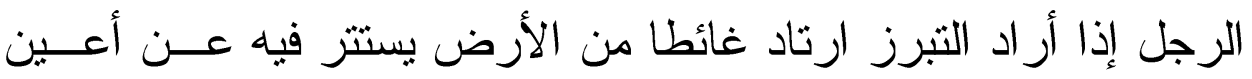

الناس ثم قيل للحدث نفسه غائطا "(") وفى المحرر الوجيز " أصل الغائط : ما انخفض من الأرض ،

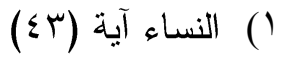

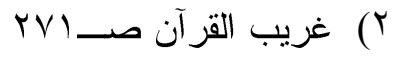

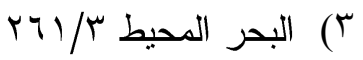


وكانت العرب تقصد بقضاء حاجتها ذلك الصنف من المواضع حتى كثر استعماله فى قضاء الحاجة وصار عرفه" (1)

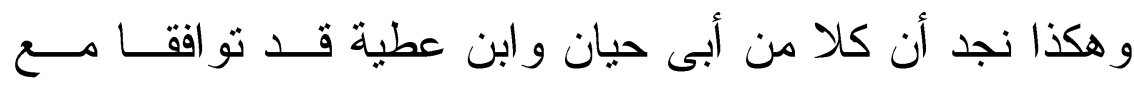

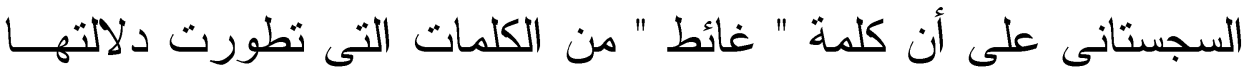

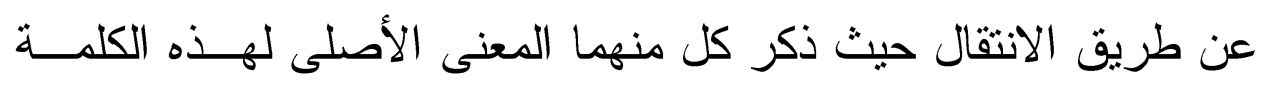

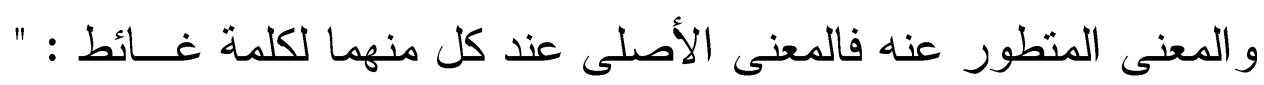

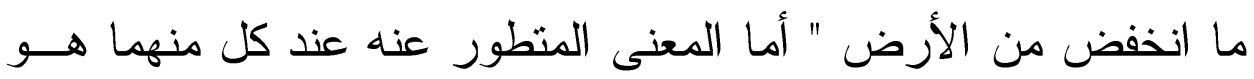

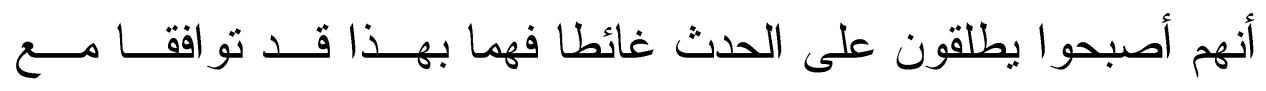
السجستانى فى كلتا الدلالتين .

צ- وقوله " تقندون"(r) تجهلون ، ويقال تعجزون فى الــر أى ،

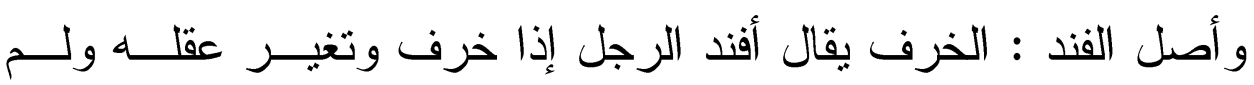

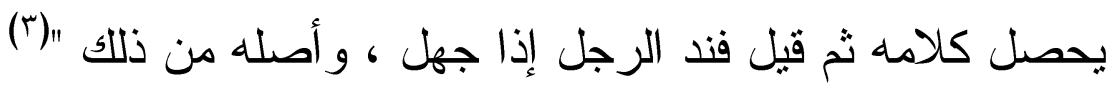
كذلك يرى السجستانى أن كلمة الفند " من الكلمات التى تطورت دلالتها عن طريق الانتقال فالمعنى الأصلى لهذه الكلمة - عنده - هو " الحرف "و أما المعنى المنطور عنه فهو "التجهيل" يدعمه ويقويه ما جاء الهن فى اللسان" الفند: الخرف و إنكار العقل، وقد بستعمل فى غير الكبــر ،

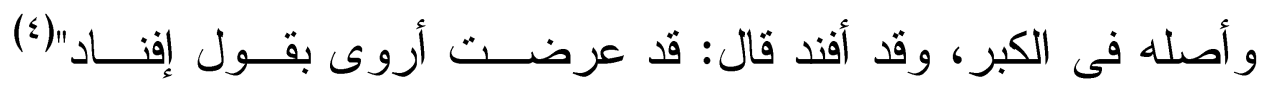

$$
\begin{aligned}
& \text { ( ) المحرر الوجيز r/؟ }
\end{aligned}
$$

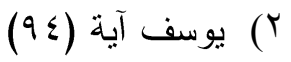

$$
\begin{aligned}
& \text { r) غريب القرآن صـ109 }
\end{aligned}
$$

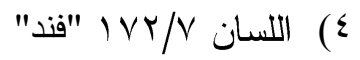


كما يقول الطبرى" و أما قوله : لولا أن تفندون فإنه يعنــى: لـــولا أن

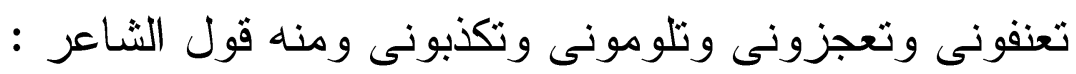

يا صاحبى دعالومى وتفتيدى ... فليس ما فات من أمرى بمردود

ويقال أفند فلانا الدهر وذلك إذا أفسده ، ومنه قول ابن مقبل :

دع الدهر يفعل ما أراد فإنه ... إذا كلف الإفناد بالناس أفندا"(1) وفى المحرر الوجيز " وتفندون " معناه تردون رأيى وتــدفعون فى صدرى ، وهذا هو التفنيد فى اللغة ، ومن ذلك قول الثاعر : يا عاذلى دعالومى وتفنيدى ... فليس ما فات من أمرى بمردود ويقال : أفند الدهر فلانا إذا أفسده قال ابن مقبل :

دع الدهر يفعل ما أر اد فإنه .... إذا كلف الإفناد بالناس أفنـــدا ومما يعطى أن الفند الفساد فى الجملة قول النابغة : ألا سليمان إذ قال الإله له .... قم فى البرية فاحددها عن الفند وقال منذر بن سعيد يقال شيخ مفند : أى قد فسد رأيه ، و لا يقــال عجوز.... قال القاضى أبو محمد رحمه الله و التفنيد يقع إما لجهل المفند ،

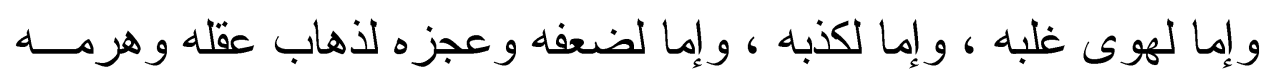

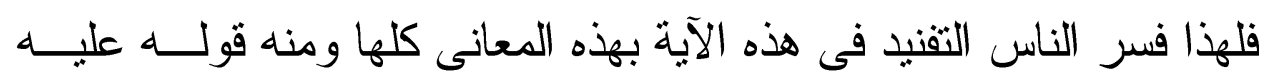

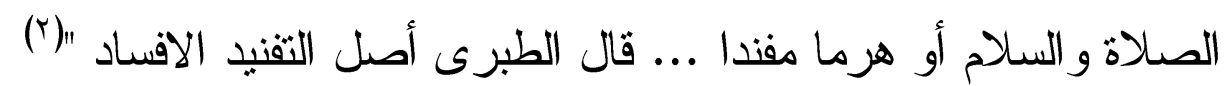

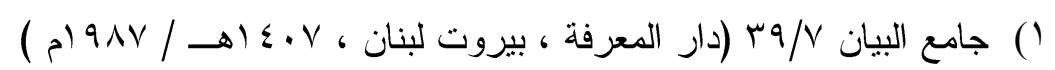

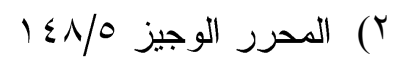




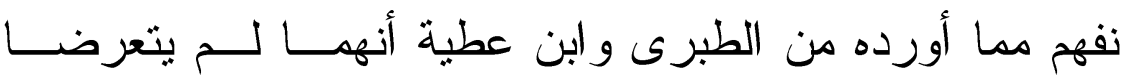
للمعنى المتطور عن الدلالة الأصلية وإن كان قد ذكر ا الدلالة الأصلية

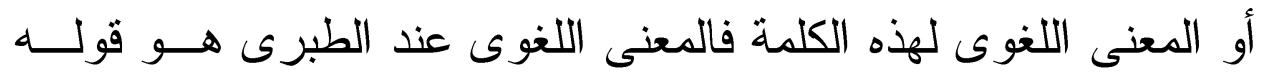

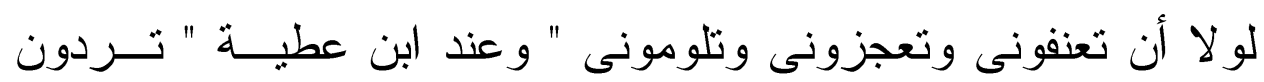

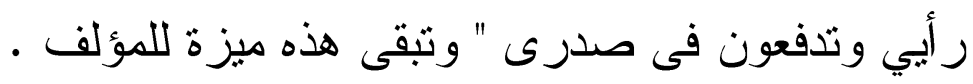

V- ويقول " منافق(') : مأخوذ من النفق وهو السرب أى يتستر بالإسلام كما يتستر الداخل فى السرب ، ويقال هو من قولهم : نــافق

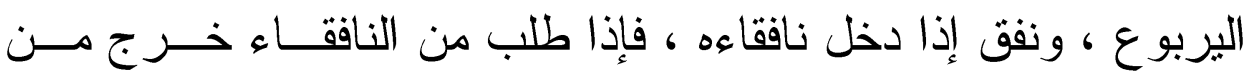

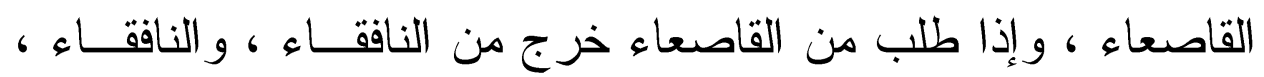

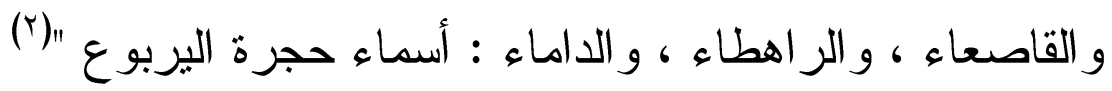
يشير السجستانى إلى أن لفظ "منافق" -مأخوذ من نفق اليربوع-

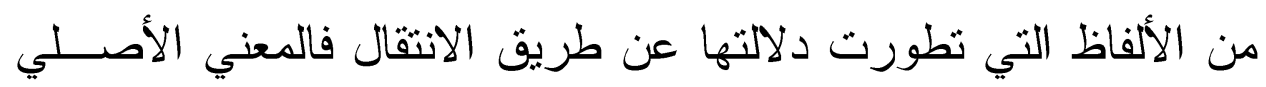

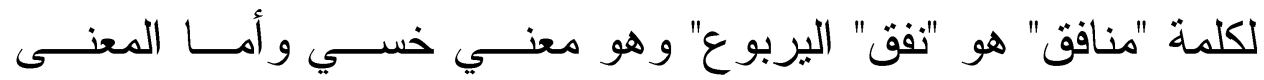

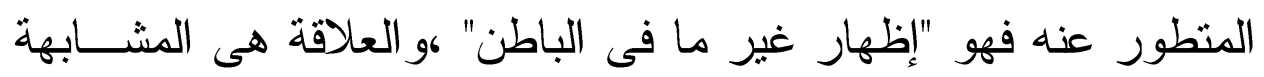

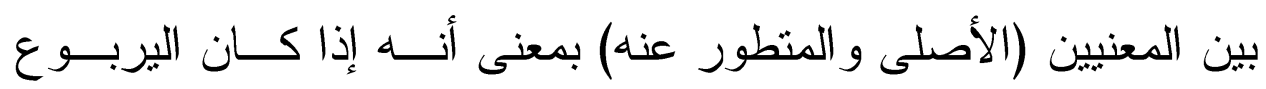
يسنتر من صائدة بالنفق (السرب) فإن المنافق يستنر فى الدنيا بالإسلام

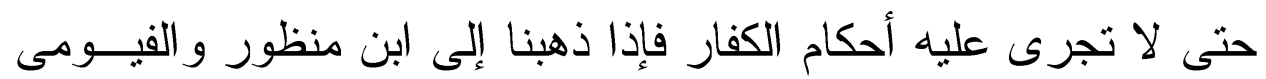

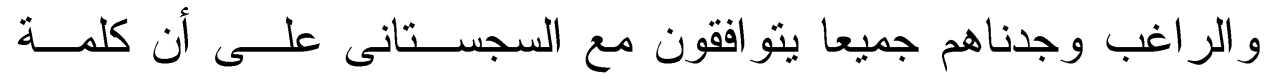

( ) فى القرآن "الهنافقون" سورة الأنفال (9؟)

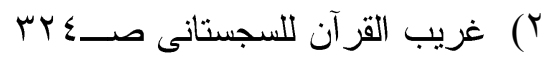


"منافق" من الكلمات التى تطورت دلالتها عن طريــق الانتقـــال فهــذا ابن منظور يقول " النفاق : الدخول فى الإسلام من وجه و الخروج عنه من آخر مشتق من نافقاء اليربوع إسـلامية ... وهو اسم إسلامهى لـــ تعرفه العرب بالمعنى المخصوص به وهو الذى بستر كفــره ويظهـر إيمانه ، و إن كان أصله فى اللغة معروفا يقال نافق يناقق مناققة ونفاقا وهو مأخوذ من النافقاء لا من النفق وهو السرب الذى يستر فيه لسترة كفره "(') كما يقول الفيوهى " نافق اليربوع إذا أنى الناققاء ، ومنه قيل نافق الرجل إذا أظهر الإسلام لأهله و أضدر غير الإسلام و أناه مع أهله

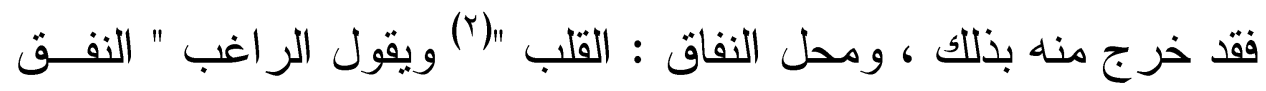
: الطريق النافذ والسرب فى الأرض النافذ فيه قال " فإن استطعث أن تبتغى نفقا فى الأرض "() ومنه نافقاء اليربوع ، وقد نــافق اليربــوع ونفق ، ومنه النفاق و هو الاخول فى الشرع من باب و الخروج عنه من باب وعلى ذلك نبه بقوله " إن المنافقين هم الفاسقون "(؛) أى الخارجون من الشرع ، وجعل الله المناققين شرا من الكافرين "(•)

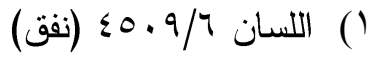

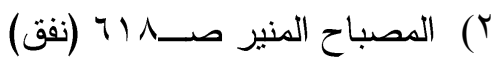

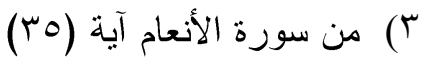

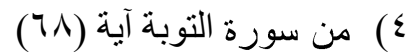

$$
\begin{aligned}
& \text { 0) المفردات صــ .0 دار المعرفة ـ بيروت لبنان }
\end{aligned}
$$




\section{الفصل الرابع}

\section{تعدد المعني للفظ وتعدد اللفظ للمعني

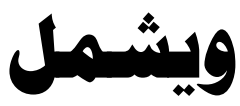

$$
\text { الترادف - المشترك اللفظي - التضاد }
$$




\section{التر ادف والاشتر الك اللفظي والتضاد :}

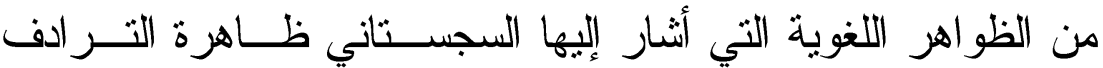
و الاشتر الك اللفظي والتضاد ، ولن أقف طويلا أمام هذه الظو اهر الثلاث ، و إنما سأعرض لكل منها عرضا يسيرا بالقدر الذي يوضح رأي المؤلف في كل منها. 1

جاء ء في اللسان أن الردف : ما تبع الثيء ، وكل شيء تبع شيئا

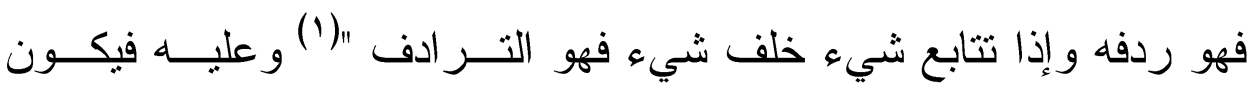

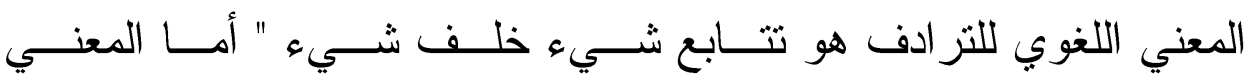
الاصطلاحي للنزادف فهو تعدد الألفاظ للمعني الواحد أي وجود لفظتين أو

أكثر تدلان علي المعني نفسه (؟). الترادف بين المثبتين والمنكرين : وقد اختلفت آراء اللغويين القدماء حول هذه الظاهرة اللغوية بين

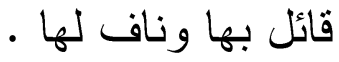
فمن السابقين الذين قالو البوقوع التــر ادف فــي اللغـــة ســبيويه

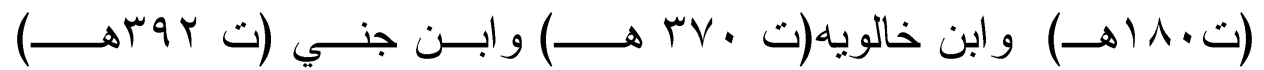
و غير هم وحجتهم في ذلك أن هنالك ألفاظا سمعت عن العرب بمعني واحــد كالحنطة و القمح. (r)

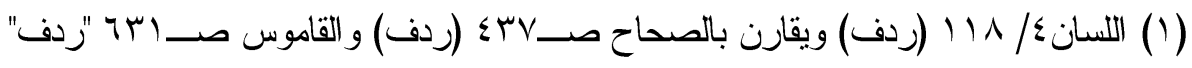

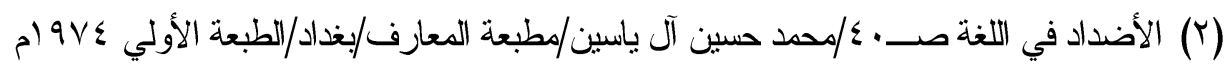

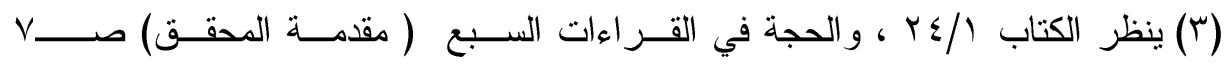

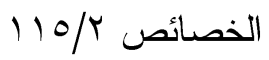


كما ذهب آخرون كابن درستوية (ت V § اهــ) و أبي علي الفارسي

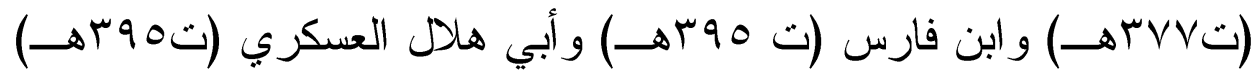
إلى إنكار وقوع الترادف في اللغة ، و الدليل علي ذلك هو أن كل ما بظــن أنه من المنر ادفات فهو من الألفاظ التي تقاربت معانيها فوقع كل منها موقع الآخر وشاع حتي صار حقيقة عرفية فقالو إن في "قعد" معني لــبس فـي

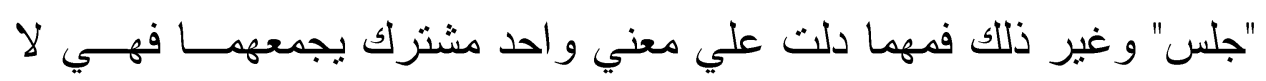
تخلو sن الفروق اللغوية. (1) أمـا أسباب وجود التز ادف فقد عز اها اللغويون (r) إلى أمسـور كثيــرة منها : تعدد أسماء الثيء الواحد في اللهجات المختلفة ، فكل لهجة تطلق عليه اسما ، ثم أدي احتكاك اللهجات بعضها ببعض إلى تمسك هذه اللغة المشتركة، بعدد من تلاك الألفاظ التي تدل علي مسمى واحد في اللهجات المختلفة. ץ- أن يكون للشيء الواحد في الأصل اسم واحد ، ثم يوصف بصفات مختلفة باختلاف خصائص ذلك الثيء و إذا بتلك الصفات نســخدم في يوما ما ، استخدام الثيء وينسي ما فيها من الوصف . r- النطور اللغوي في اللفظة الواحدة ـ فقد تتطور بعــ أصــوات

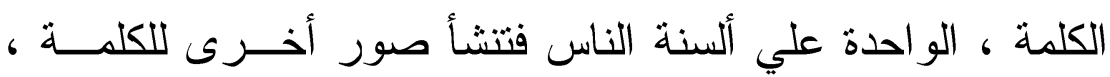
و عندئذ تعد مثز ادفات لمسمى و احد. 
ع- الاستعارة من اللغات الأجنبية التي كانـــت تجــاور العربيــة فـي الجاهلية ، وصدر الإسلام وبين الكلمات المنز ادفة التي روت لنــا الكثير من الألفاظ المستعارة من الفارسية وغيرها. هذا برى الدكثور / عبدالغفار هلال أن منشأ الخلاف بين العلماء حول التر ادف يعود إلى منهجية الباحث في در اسة دلالة الألفــاظ فالـذـين درسوا هذه الألفاظ در اسة تاريخية أو من خلال المنهج التــاريخي الــذي يتناول الكلمة منذ نشأتها ، وتطور ها الدلالي بمعني أن الباحث التاريخي إذا كثف عن معاني مجموعة من الألفاظ ير اها متحدة المعني أمامه ، ولكــن وقائع التاريخ تبين له اختلاف العصر أو البيئة اللغوية أو التطور الصوتي الذي نجم عنه اختلاف اللفظين صورة و اتحادهما معني و عندئذ لا يعتــرف بوجود تز ادف بينهما أما الذين درسو ا هذه الألفاظ در اسة وصــفية أو مــن خلال المنهج الوصفي الذي يدرس طائفة من الألفاظ في عصر مـــا مــن العصور ، ويحدد مفاهيمها ودلالتها في ذلك العصر دون النظر إلى ســـواه من عصر أو بيئات أو تطور ات .

و علي هذا فيمكن للباحث أن يرى طائفة مـنـ الألفــاظ اختلفـــ صور ها و اتحد معناها فيحكم بوجود التر ادف بينها. ثم ينتهي الدكتور / عبدالغفار هلال إلى أنه لا مناص من القــول بوجود التز ادف لكن دون مغالاة فقال " ويتبين من النظر إلى آراء المنكرين و المثبتنين - علي سواء - أنهم مبالغون ومتطرفون فليس من المعقول إنكار تللك الثزوة اللغوية وجهل مز اياها ، كما أنه ليس من اللائق إثبات وجــود 
التز ادف بين كل لفظين بظهر إتحادهما في المعني ، و الأمثل القول بالوجود

مع البحث و النأني. (1)

\section{موقف السجستاني من التر ادف :}

عالج السجستاني ظاهرة التز ادف في أكثر من موضع من كتابه من

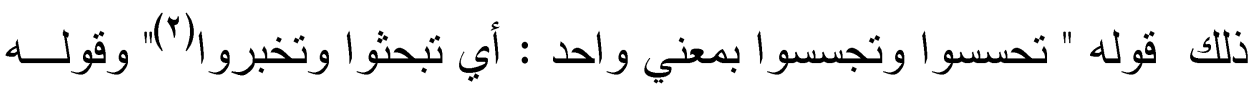

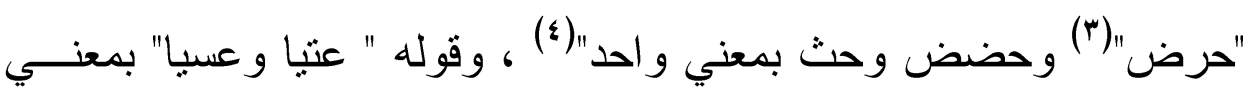

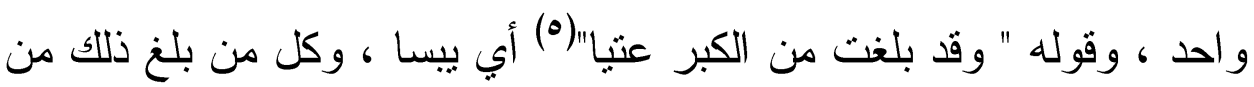
كبر أو كفر أو فساد فقد عنا وعسا عنيا ، وعنو اوعسيا "(†) وقوله " كــدأب

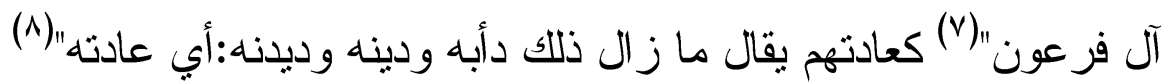

وقوله " تلقف"(9) وتلقم وتلهم بمعني واحد أي تبتلع ويقال تلقفــهـ

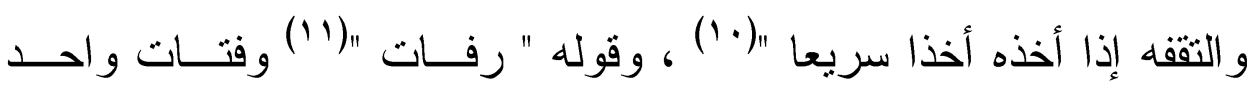

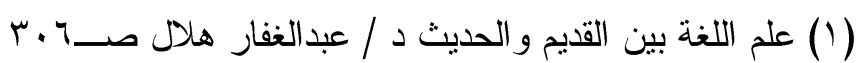

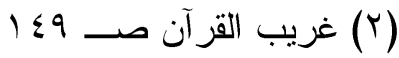

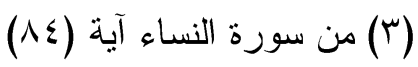

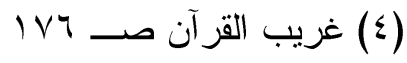

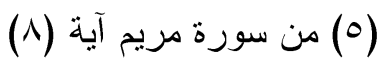

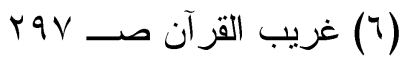

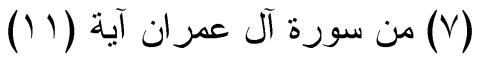$$
\text { r १V (^) }
$$

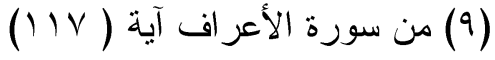

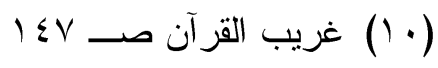

(1') في القرآن ( رفاتا) من سورة الإسراء آية (1) (1) 
يقال الرفات ما تناثز وبلي من كل شيء"(1) ويقول أيضــا (" عـاقر"(r) و "عقيم"() بمعني و احد وهي التي لا تلا و الذي لا يولد له أبضا"(؛) كما يقول

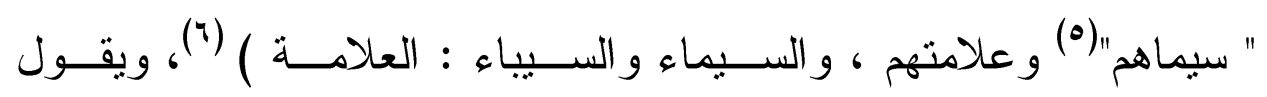

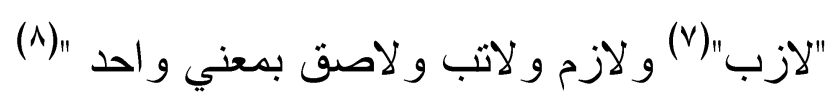

: تعقيب

- هذا ولعنا نلاحظ من خلال هذه النماذج النسعة أنه لم يصرح في

أي منها بكلمة التز ادف ، وبناء علي ذلك فإن السجستاني كان بري الترادف هُه لكن دون مغالاة أو تعسف ، ودليلنا علي ذلك قله الكلمات التي عالجها علي مستوي القرآن الكريم فهي لم تتجاوز تسع كلمات ثقريبا تلك التي ذكرناها.

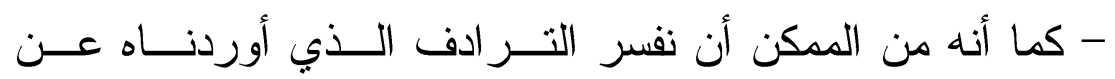

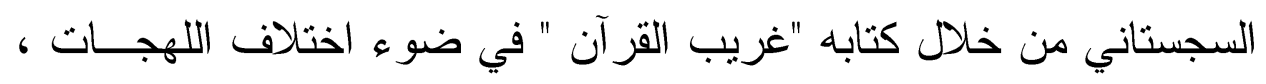
ولذلك يقول ابن جني "كلما كثرت الألفاظ علي المعني الواحد كان ذلك أولى هلى

بأن نكون لغات لجماعات اجتمعت لإنسان و احد من هنا وهنا".(9)

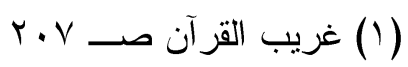

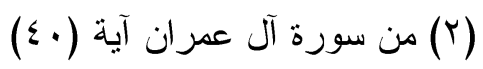

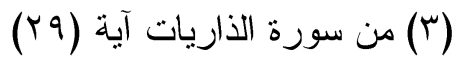

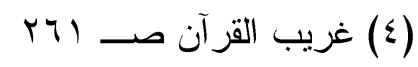

$$
\begin{aligned}
& \text { (0) من سورة البقرة آية (YVY) }
\end{aligned}
$$

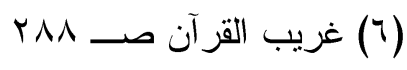

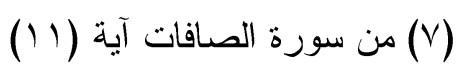

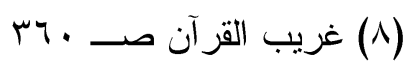

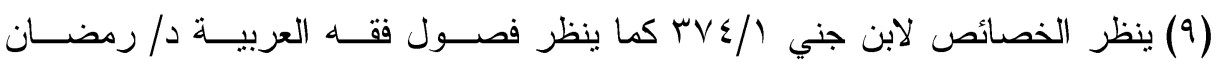


-كما قال الأصوليون "إن من أسباب التر ادف أن تضـــع إحــدي

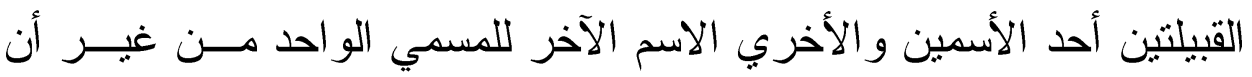

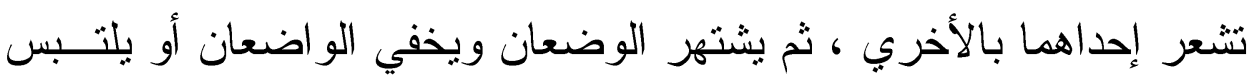
وضع إحدهما بوضع الأخري". (1)

\section{r}

أمسا المشترك اللفظي فقد عرفه العلامة أحمد بن فـــارس بقولــهـ :

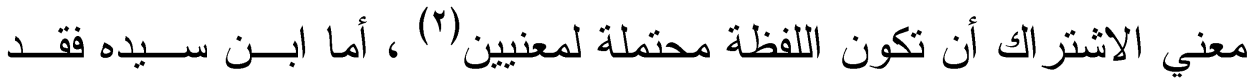

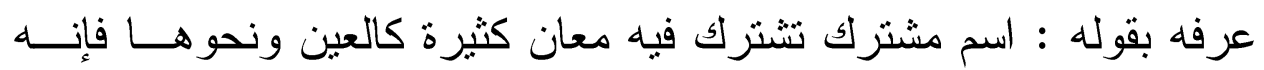
يجمع معاني كثيرة. أسباب وجوده في اللغة : رصد له اللغويون( ) أسبابا كثيرة منها:1- اختلاف اللغات و اللهجات : بمعني أن اللغة قد تستمد ألفاظا مــن لغات أجنبية عنها ، وذلك قد بسبب بجانبها ألفاظ أخرى فبها - قد تتحد معها في الصبغة - وجود المشترك اللفظي. ץ- تطور المعنى : فإذا تطور معنى اللفظ وبقيت أصو اته دون تغييــر أدى ذلك إلى حدوث الاشتز اك.

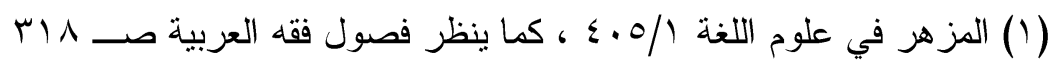

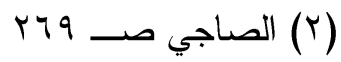

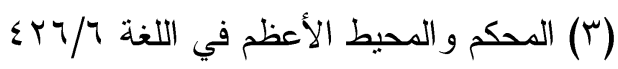

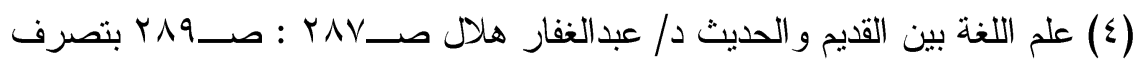




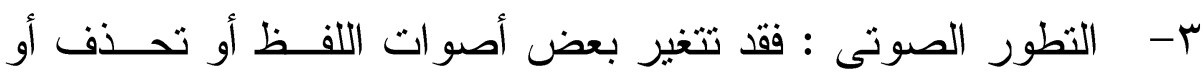

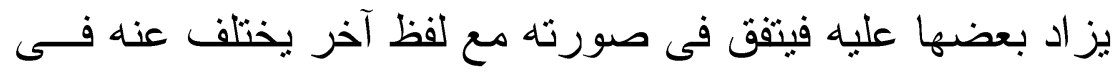

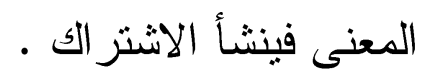

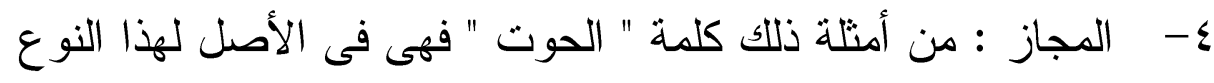

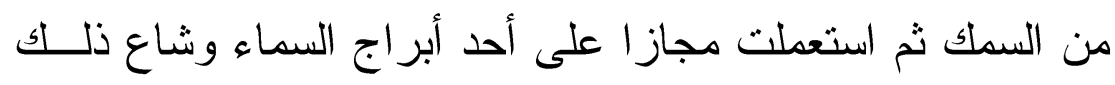
حتى صار حقيقة فيه آراء العماء فيه : - و

\section{اختلف العلماء فيه بين منكرين ومؤيدين :}

1- أما المنكرون وفى مقدنهم ابن درستويه فإنهم يذهبون إلى القــول

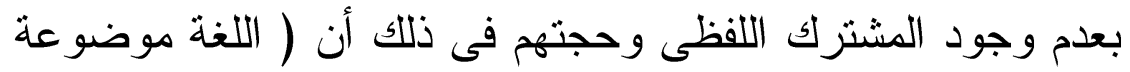

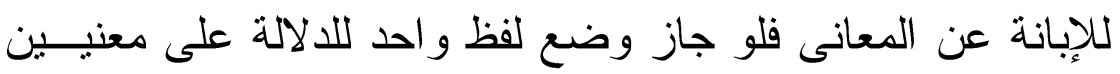
مختلفين أو أحدها ضد الآخر لما كان ذلك إبانة بل تعمية وتغطية)

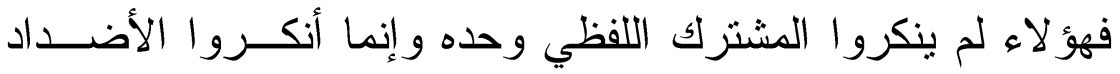

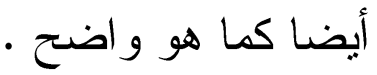

وأما المثبتون - وفي مقدمنهم الخليل وسيبويه و الأصمعي و غبرهم - فإنهم يذهبون إلى القول بوجود المشترك اللفظي ودليلهم علي ذلك وجود الألفاظ التي وقع فيها الاشتر الك في لغة العرب و أساليبهم و لا يمكن إنكارها ، أما الإبهام فإنه يزول بالقر ائن الصارفة.

وعلي كل حال فإنه يبدو لنا أن كلا الفريقين مبالغ فيما ذهب إليه .

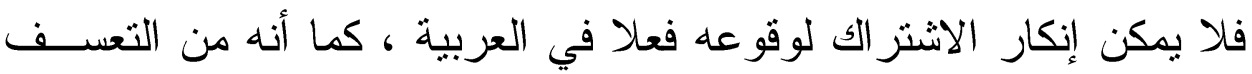

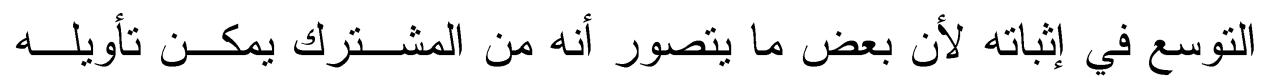


و إخر اجه هن هذا النطاق و الرأي الأجدر بالقبول هو ما ذهب إلبـــهـ أكثــر

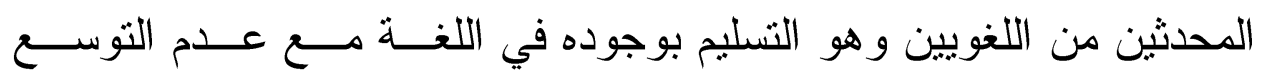

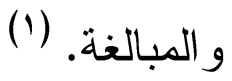

\section{موقف السجستاني من المشترك اللفظي :}

عالج السجستاني الششترك اللفظي في أكثر من موضع كـــللك مـن

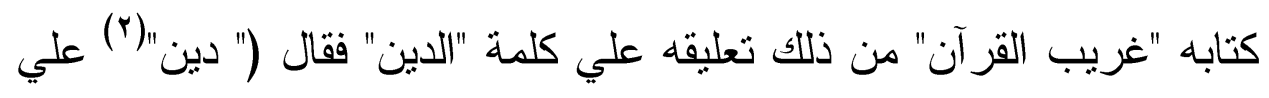
وجوه منها الدين : ما يتدين به الرجل من الإسلام وغيره ، و الدين الطاعة داعل

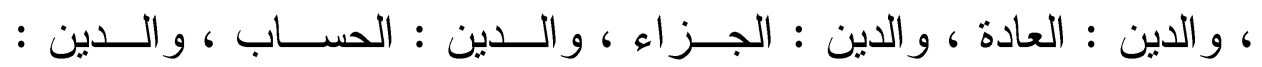

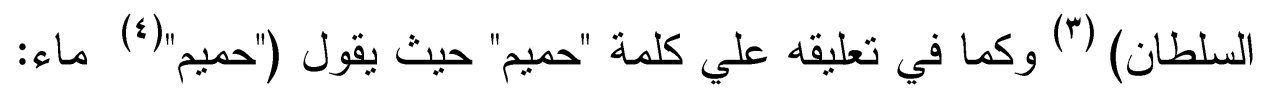

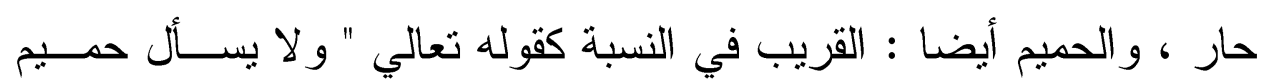

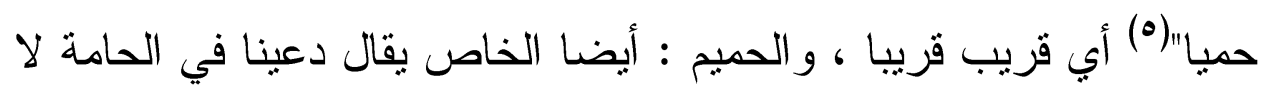

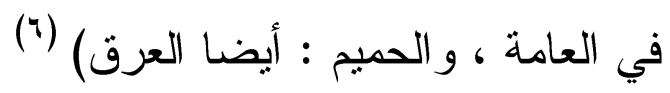
وكما في نعليقه علي كلمة "الصلاة" فقال (الصلاة علي خمسة أوجه

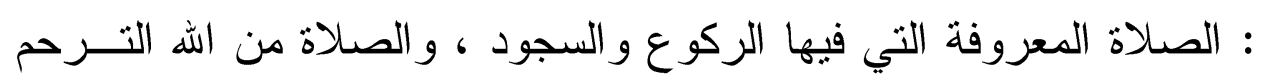

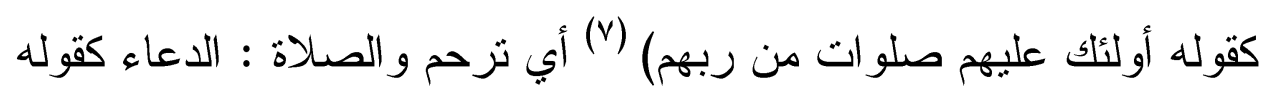

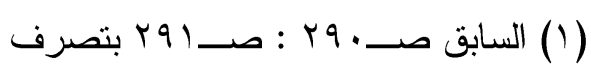

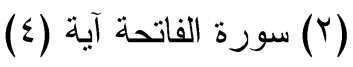

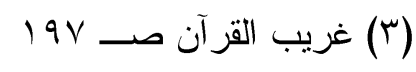

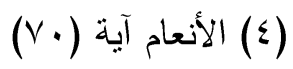

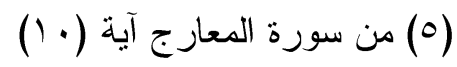

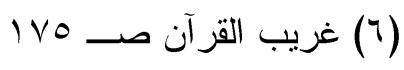

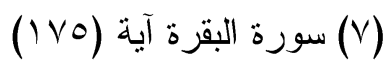




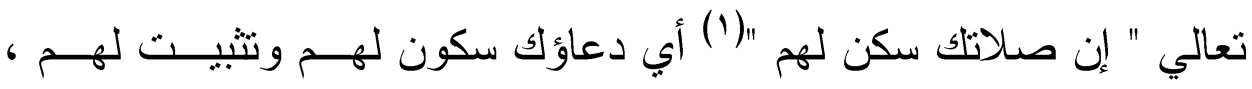
وصلاة الملائكة للمسلمين استغفار لهم ، والصلاة : الدين كقوله نعالي " يا ليا لهابل

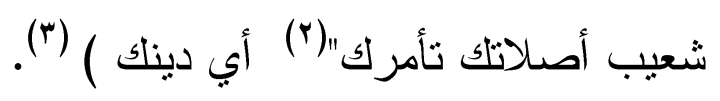

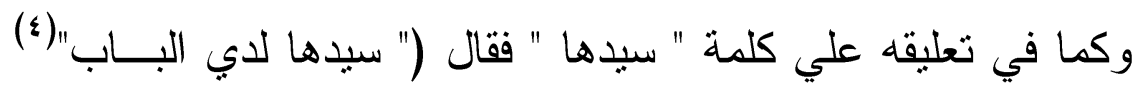
يعني زوجها و السيد : الرئيس أيضا ، و السيد : الذي يفوق في الخير قومه

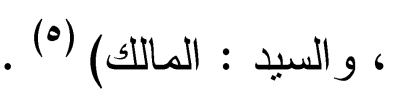

- وكما في تعليقه علي كلمة "أمه"(") حيث فال ("أمة" علي ثمانيــة

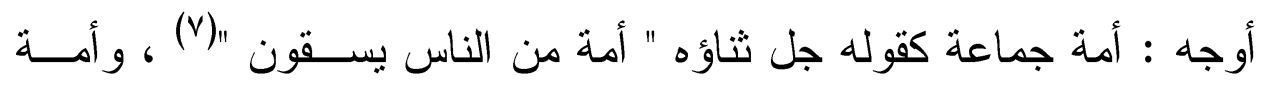

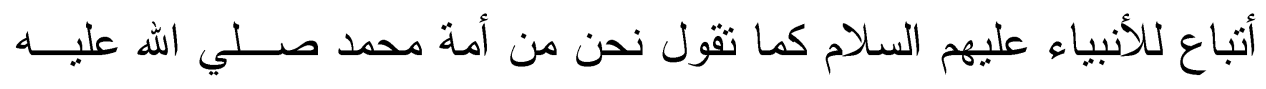

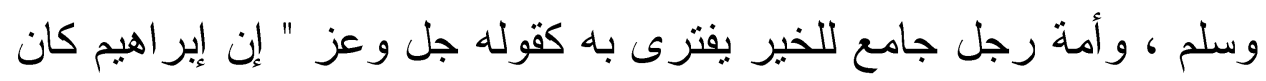

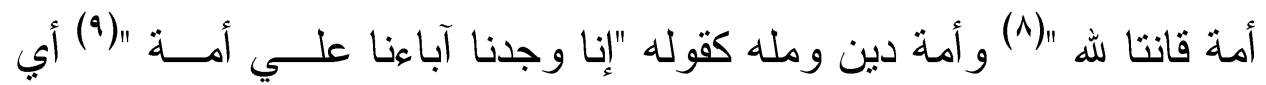

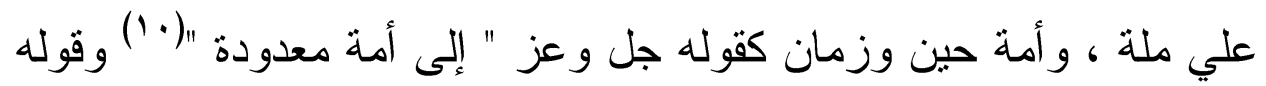

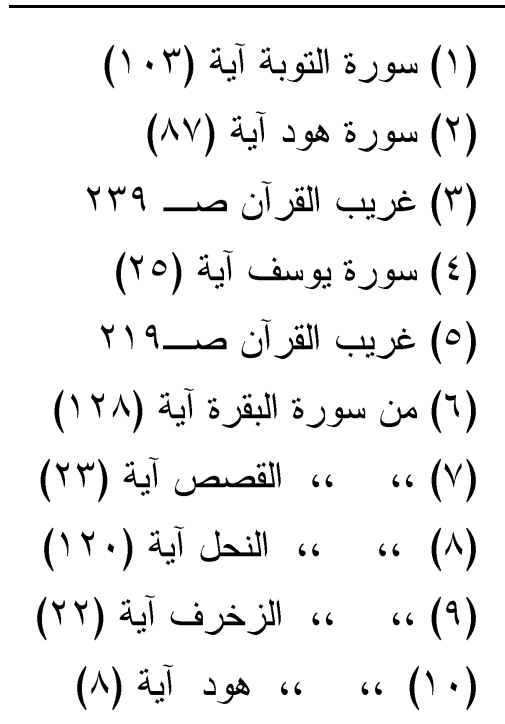


"و ادكر بعد أمة"(1) أي بعد حين ... و أمة قامة يقال فلان حسن الأهــة أي

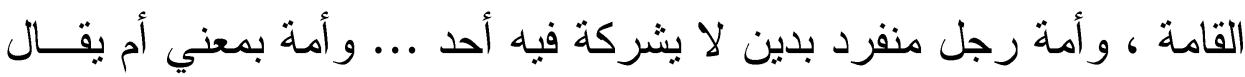

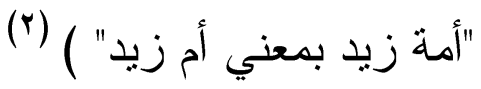
- وكقوله أيضا ("الأرحام" (ّ) القر ابات و احدها رحم ، و الرحم فــي

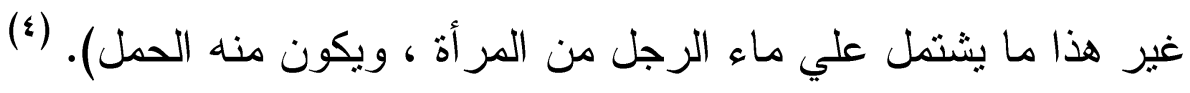
- وكقوله أيضا ("زوجناهم بحور عين"(ه) قرناهم بهن ولــبس فــي

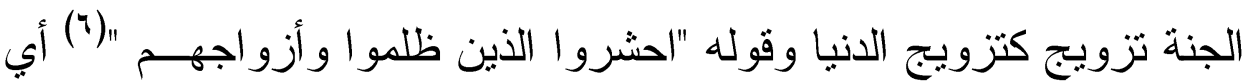
وقرناءهم ، و الزوج الصنف أيضا كقوله نعالي " سبحان الذي خلق الأزو اج

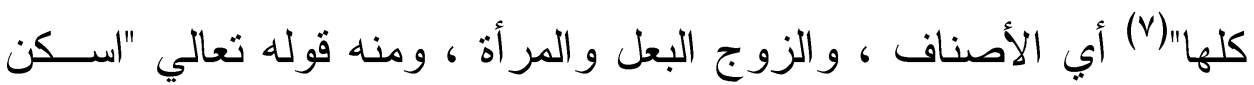

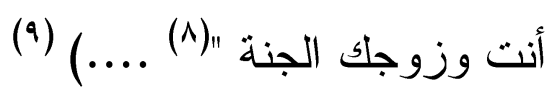

$$
\text { (1) من سورة يوسف آية (1) (1) }
$$

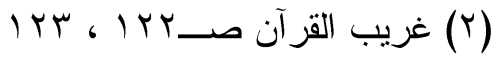

(Y) سورة آل عمران آية (T)

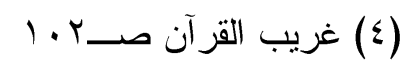

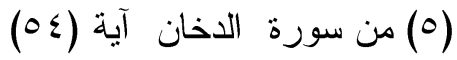


- وكقوله أيضـا ("سلم"(1) استشلام و انقياد ، و "السلم" السلف أيضـــا و "السلم " شجر أبضـا و احدتها سلمة ، و السلم و السلم بتسكين الــلام وفــتح السين وكسر ها : الإسلام و الصلح أيضا ، و السلم أيضا : الدلو العظيمة) (r) - وكما في قوله أيضا ("سلام"() علي أربعة أوجه : السلام : الله تعالي كقوله سبحانه "السلام المؤمن المهيمن"(؛) ، و السلام : السلامة كقوله اله

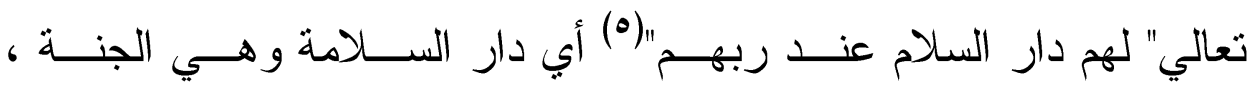
و السلام : التسليم بقال سلمت عليه سلادا أبي تسليما و "السلام" شجر عظام

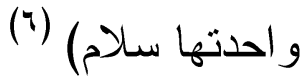

- وكقوله أيضا ("سامدون" (v) لاهون ، و السامد علي خمسة أوجه : السامد : اللاهي و السامد : المغني ، و السامد : الهائم ، و السامد : الساكت ، ولهوبه

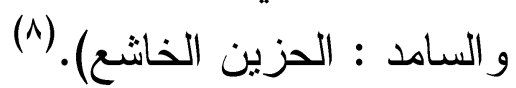

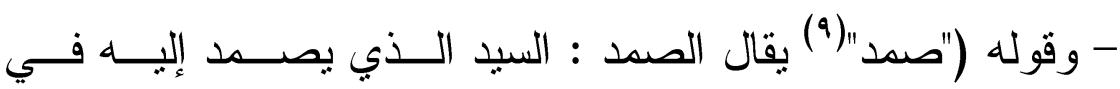
الحو ائج ليس فوقه أحد ، و الصمد أيضا الذي لا جوف له) (··)

$$
\begin{aligned}
& \text { (1) من سورة النساء آية (99) }
\end{aligned}
$$

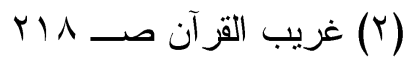

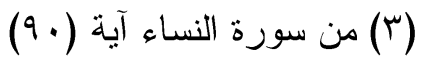

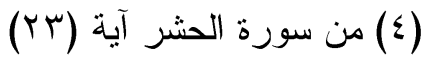

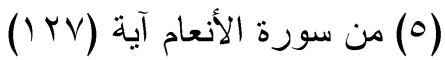

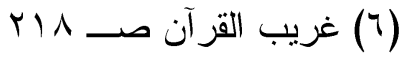

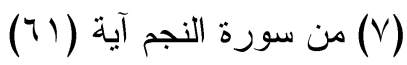

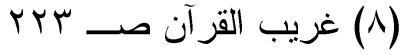

$$
\begin{aligned}
& \text { (9) من سورة الإخلاص آية (Y) (1) }
\end{aligned}
$$

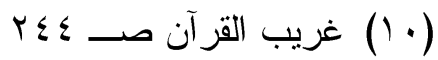


- وقوله ("طلح"(1) موز ، و الطلح أيضا شجر عظام كثير الثوك) (r)

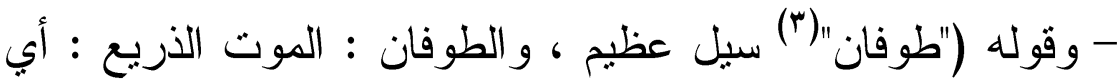

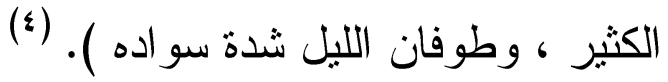
- وقوله ( "القنوت علي وجوه" : القوت : الطاعــة ، و القنــوت :

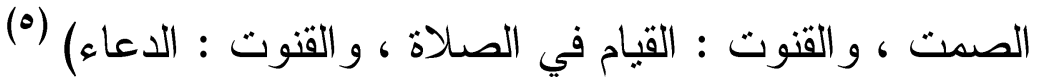

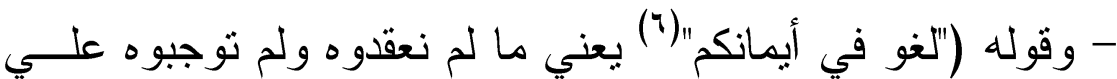
أنفسكم ... و اللغو : أيضـا : الباطل من الكلام ... و اللغو أيضــــا واللغــــا : الفحش من الكلام .. و اللغو أيضا الثيء المسقط الملغي : تقول : ألغيــت الشيء : إذا طرحته و أسقطنه) - وقوله ("مرجومين" (^) أي مقتولين و الرجم : القتــلـ ، و الـــرجم :

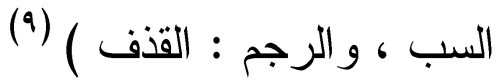
- وكما في قوله (" مقينا"(· (1) مقتدر ا ... و المقيت : الثـاهد الحــافظ للثيء ، و المقيث الموقوف علي الشيء.. ) ('1)

$$
\begin{aligned}
& \text { (1) من سورة الو اقعة آية (•0) } \\
& \text { ro }
\end{aligned}
$$

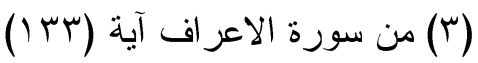

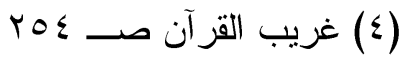

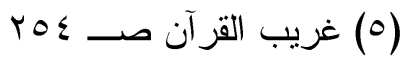

$$
\begin{aligned}
& \text { (T) من سورة البقرة آية (T) (1) (1) } \\
& \text { rAV غريب القزآن صـ (V) } \\
& \text { (1) من سورة الثعر اء آية (1) (1) (1) (1) }
\end{aligned}
$$

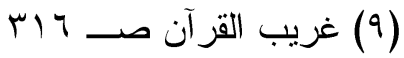

$$
\begin{aligned}
& \text { (1) (1) من سورة النساء آية (1) (1) (1) }
\end{aligned}
$$

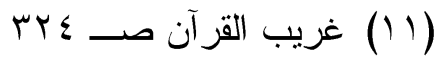


1- وبعد فهذه شو اهد المشترك اللفظــي فــي "غريــب القــر آن"

للسجستاني ، وقد بلغت نحو ا من خمس عشرة كلمة تقريبا ، ولعل الســبـ في نشوء المشترك اللفظي في هذه الكلمــات يرجــع إلـى الاســتـعمالات المجازية فمثلا كلمة طوفان لعل الاستعمال الحقيقي لها هو " السيل العظيم" ثم استعملت مجاز ا بمعني الموت الذريع : أي الكثير كما استعملت مجــاز ا بمعني شدة سو اد الليل ، وكذا كلمة " القنوت " لعل الاستعمال الحقبقي لها : القتوت في معنى الطاعة ، ثم جاءت الاستعمالات الباقية لهذه الكلمات علي سبيل المجاز و الاتساع ... و هكذا الخ • Y- أن السجستاني لم يصر ح في أي مــن هــــه الثـــو اهد بكلمـــة المشترك اللفظي أي علي عادنه في التر ادف . ب- كما أن السجستاني و إن كان من هؤلاء الأئمـــة الــذين بــرون المشترك اللفظي إلا أنه كان معتدلا ، و الدليل علي ذلك هذا القدر القليل من هذه الكلمات. التي عالجها حيث لم تزد علي خمس عشــرة كلمــة علـي مستوي القرآن الكريم كله .

r- التضاد :

عرفه أبو الطيب اللغوي في صدر كتابه فقال " الأضداد : جمــع ضد ، وضد كل شيء ما نافاه : نحو البياض و السو اد ، و السخاء و البخـلـل و الشجاعة ، و الحين ، وليس كل ما خالف الثيء ضدا له ألا ترى أن القوة و الجهل مختلفان ، وليسا ضدين ، و إنما ضد القوة الضعف ، وضد الجهـلـ 
العلم فالاختلاف أعم من التضاد إذ كان كل متضـادين مختلفين وليس كـلـ

مختلفين ضدين "(1)

\section{أسباب وجوده في اللغة :}

رصد اللغويون(r) أسبابا كثيرة لنشوء هذه الظاهرة اللغوية منها :

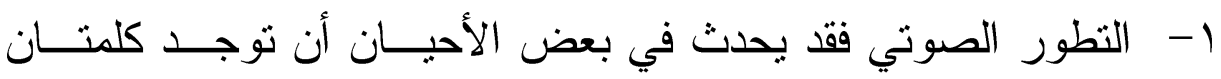

مختلفتان لهما معينان متضـادان فتتطور أصو ات إحــداهما بصــورة

تجعلها تتطبق علي الأخرى تماما فيبدو الأمر كما لو كانــــ كلمــة

و احدة لها معنيان متضادان.

r- المجاز و الاستعارة : و أوضح مثال لهذا السبب هو إطلاق كلمة الأمة علي الجماعة و علي الفرد فإنه مما لاشك فيه أن الفرد لا بقال له أمه إلا علي التشبيه بالجماعة علي وجه المبالغة ، فيقال عن هذا العـالم أو ذالك " كان أمه وحده " بعني أنه كان في رجحان عقله وحدة ذكائه جماعة بأسر ها فاستعير له لفظ بطلق في العادة علي الجماعة . r- اختلاف اللهجات : ولذلك يقولون إذا وقع الحـرف علـي معنيـين منضادين فحال أن يكون العربي أوقعه بمساو اه بينها ، ولكن أحد المعنيين لحي من العرب و المعني الآخر لحي غيره ثم سمع بعضهم لغة بعض فأخذ هؤلاء عن هؤلاء ، وهؤلاء عن هؤلاء (r).

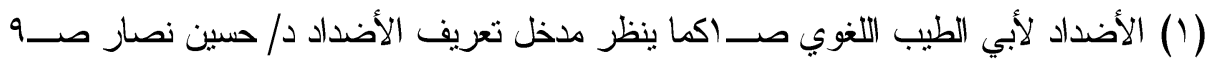

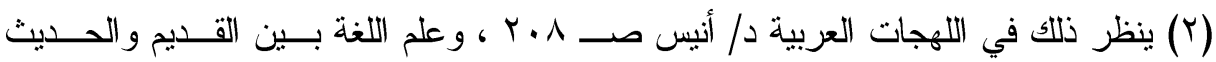

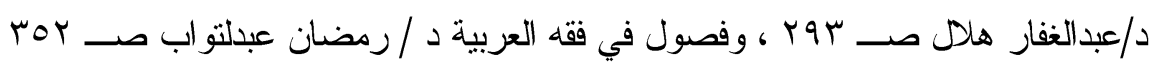

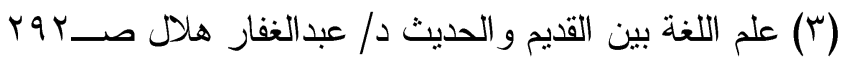


ع- التهكم : لا شك في أن عامل التهكم و السخرية من العوامـلـ التـي عي تؤدي إلى قلب المعني وتغيير الدلالة إلى ضدها في كثير من الأحيان

من ذلك إطلاق العاقل علي الجاهل (1)

\section{التضاد بين المثبتين والمنكرين :}

مما لاشك فيه أن موقف اللغوبين من التضـاد كــان كــــوقهم مــن

المشنرك اللفظي فقد انقسموا إلى قسمين منهم دن بري وقوعه فــي كـلام العرب ومنهم من ينكره قال ابن فارس " من سنن العرب في الأســماء أن يسمو ا المتضادين باسم و احد نحو الجون للأسود ، و الجون للأبيض ، و أنكر ناس هذا المذهب ، و ان العرب تأنى باسم و احد لشئ وضده "(r)

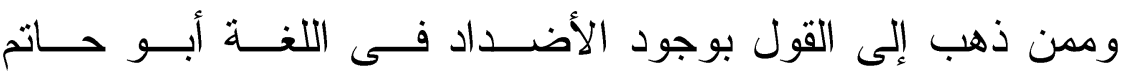
السجستانى، ويعقوب ابن السكيت.

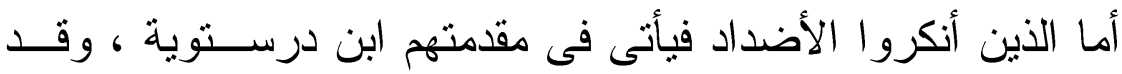
ذكرنا سابقا أنه أنكر الاشتر الك ، وقد صنف فى هذا الموضوع كتابا أسماه :

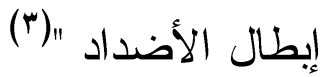


موقف السجستانى من التضاد : كان السجستانى من هؤلاء العلماء المقرين بالتضـاد فقد صرح بــه

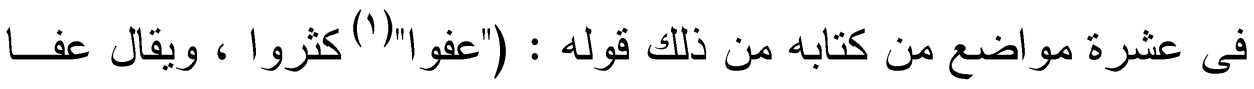

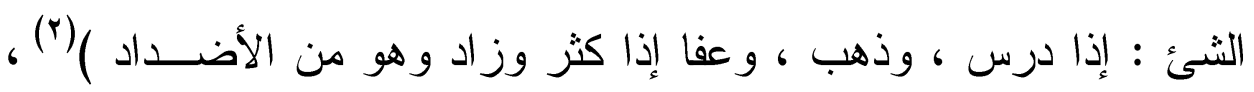
وقد واققه شيخه أبو بكر بن الأنباري علي عد هذه اللفظة دن الأضداد فقال " يقال : عفا الشيء : إذا نقص ودرس ، و عفا : إذا كثر قـال الله عز وجل "حتى عفو ا" فمعناه حتى كثرو ا"(ّ) أما الدكتور / إبر اهيم أنيس فلم يو افقهما علي ذلك ولم ير لكلمة عفا إلا معني واحهـدا هـــ "درس اله وذهب وحينئذ لا تضاد في هذه الكلمة ولذلك يقول "المشهور في معني "عفا المكان" هو درس ونسي أمره ، ولكن ابن الأنباري يتصور لهــا معني ضديا بجانب المعني الأصلي ، ويستشهد بقوله تعالي "ثــم بـــلنا مكان السيئة الحسنة حتى عفو اوقالو ا قد مس آباءنا الضر اءو السراء : ويفسر "حتى عفو ا" هنا قائلا : أي كثروا ! ويظهر والله أعلم أن المعني : حتى انــدرس أمسـرهم ونســي

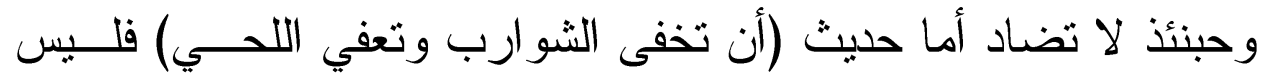
معني إعفاء اللحي تكثير شعر ها كما بزعم ابن الأنباري ، و إنما يكون

$$
\begin{aligned}
& \text { (1) من سور الأعر اف آية (90) }
\end{aligned}
$$

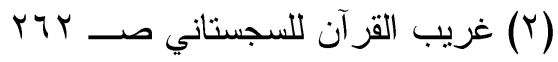

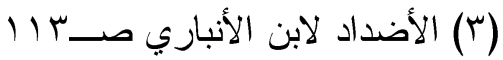


بتركها و إعفائها من الإعفاء و القص"(1) هـــذا ويـــدو أن الحــق مـــع السجستاني وشيخه أبي بكر بن الأبباري.

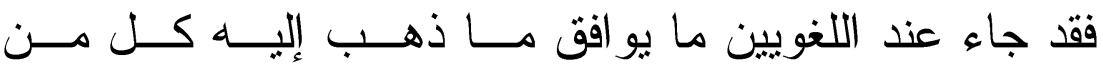
السجستاني وشيخه ففي الصحاح "عفا المنزل يعفــو درس ... و عفــا الشعر و النبت و غير ها كثر، ومنه قوله تعالي "حتى عفو ا" أي كثرو ا"(r) ، وفي للسان "عفا القوم : كثروا ، وفي التنزيل "حتى عفو ا" أي كثروا ، و عفا النبت و الشعر وغيره يعفو فهو عاف : كثــر وطــال ، وفــي الحديث أنه صلي الله عليه وسلم أمر بإعفاء اللحـى : هـــو أن بــوفر شعرها ويكثر ولا يقص كالشوارب من عفا الشيء : إذا كثر وزاد ... و عفا الأثز بمعني درس و امحي "(r)" وهكذا نرى أن كلا من الجوهري وابن منظور قد ذكر لهـــه الكلمة معنيين متقايلين هما عفا الشيء إذا درس و امحي ، و عفا الشيء: إذا كثر ، وقد جعل الجوهري من معني الكثرة : عفا النبــت و الثــعر و غيره إذا كثز وطال ، ومثله فعل ابن منظور إلا أنه زاد عليه الحديث فجعله أيضا من معني الكثرة، و علي كل حال فإن تكلف الدكتور أنبس و اضـح في إخراج هذا اللفظ دن الأضداد ، وفي كلام الجوهري وابـن منظور قنعة في إبطال ما ذهب إليه.

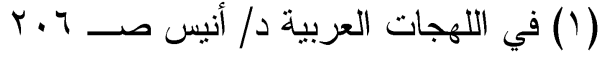

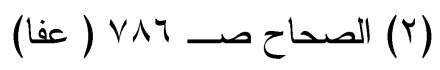

$$
\begin{aligned}
& \text { (ץ) اللسان ( }
\end{aligned}
$$


كما يقول في موضع آخر ("عسعس"(') الليل : أقبل ظلامه ،

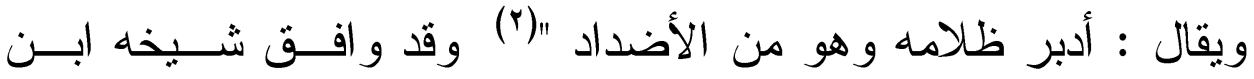
الأنباري علي عد هذه اللفظة من الأضداد حيث يقول ابــن الأنبــاري

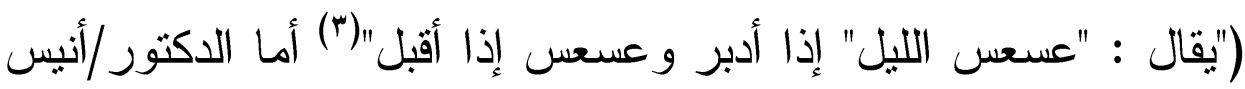

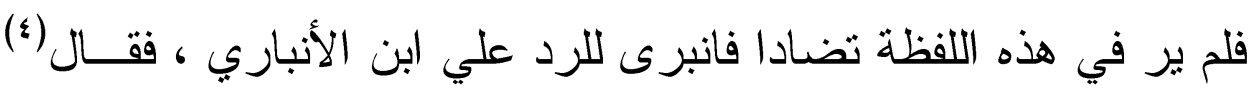

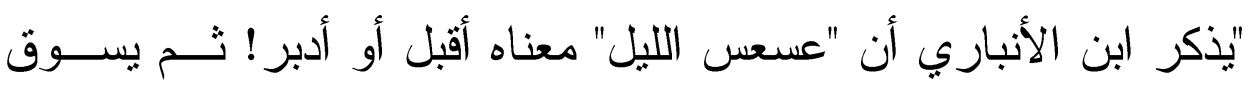
بعض الثو اهد الثُعرية للبرهنة علي ما يقول ، وليس من بـين هـــه الثو اهد ما هو منسوب لصاحبه إلا بيتان أحدهما لأمرئ القيس و الآخر لعلقمة بن قرط ، علي أن الفراء قد وصف ما نسب لأمرئ القيس بأنه

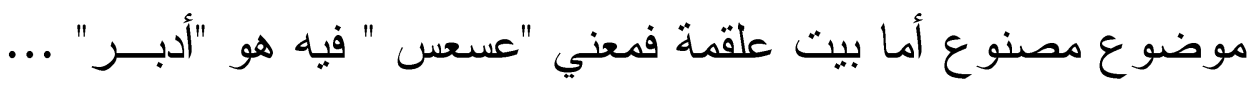
فإذا رجعنا إلى القرآن الكريم وجدنا الكلمة قد وردت فيه مرة واحدة ،

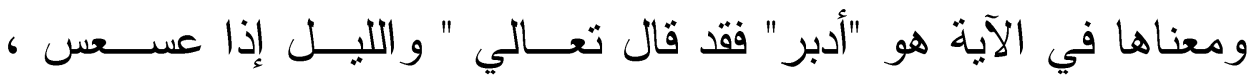

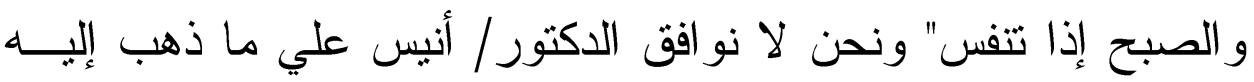

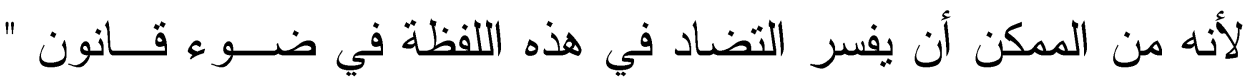

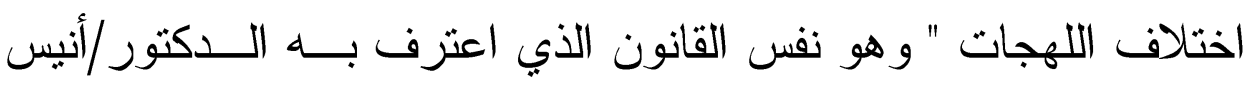

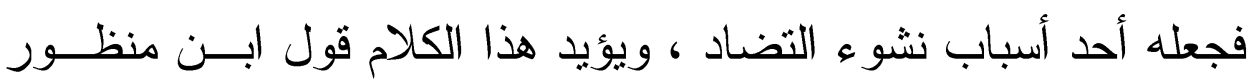

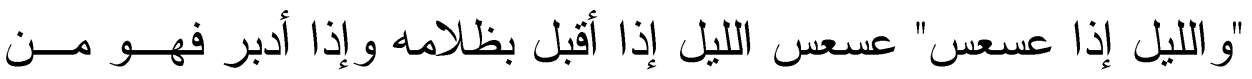

(l) (l) (l) من سورة التكوير آية (Y)

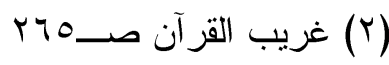

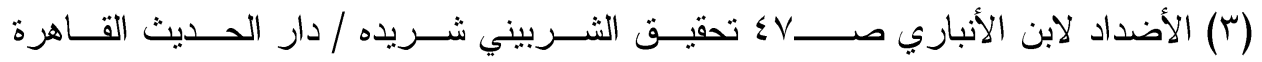

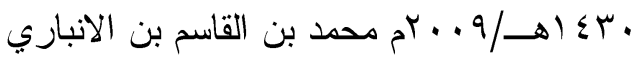

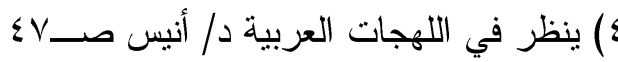


الأضداد ، ومنه حديث قس : حتى إذا الليل عسعس ... ثم لننظر إلـى

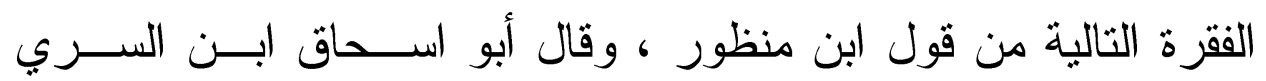

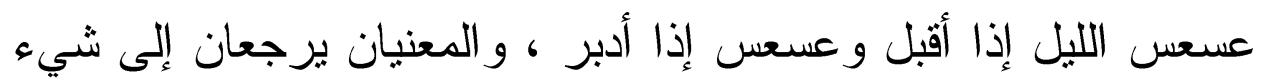

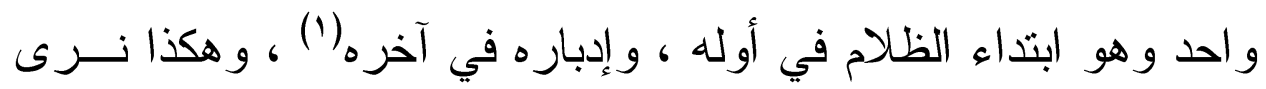

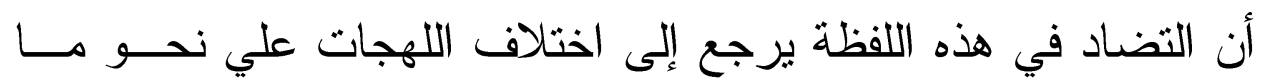
فسره أبو إسحاق السري. ويقول السجستاني أيضـا "مقوين"(†) مسافرين سموا بذلك لنــزولهم

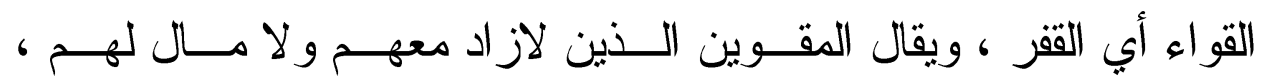

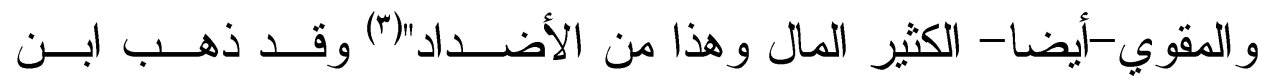
الأنباري أيضا إلى عد هذه اللفظة من الأضداد فقال (يقال : رجل مقو : إذا كانت ركابه قوية وحاله حسنه ، ورجل مقو : إذا ذهب زاده وعطبت

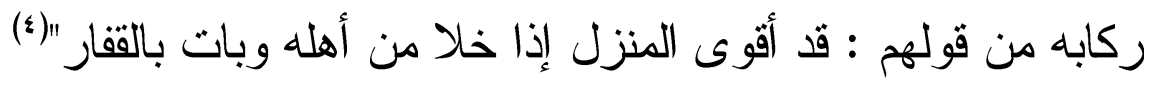

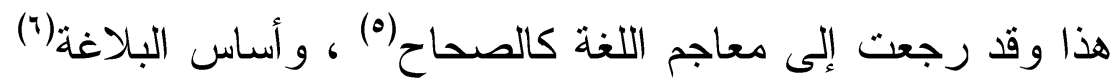

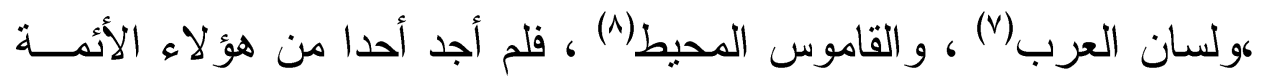

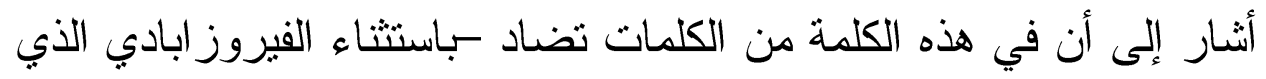

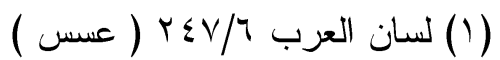

$$
\begin{aligned}
& \text { (Y) من سورة الو اقعة آية (Yr) }
\end{aligned}
$$

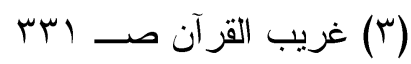

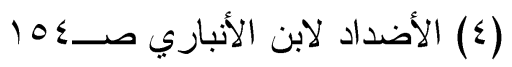

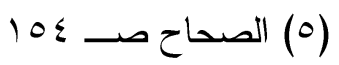

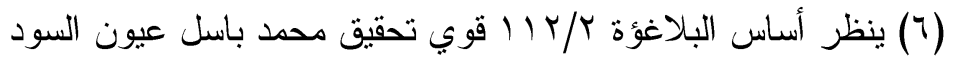

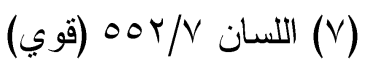

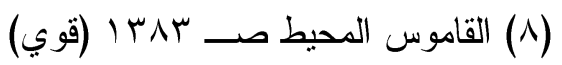


قال"أقوي استغني و افتقر ضد" - بل أشاروا جميعا إلى أنه يقال : رجل مقو إذا ذهب و عطبت ركابه .

كما أن ابن الأنباري وكذا تلميذه السجستاني لما ذكـــر أن لهـــه الكلمة معنيين منقابليين لم يستشهدا إلا علي معني المقوي الذي لا زاد له ، و هذا كله قد يلقي ظلا كثيفا من الثك حول عد هذه الكلمـــة مــن الألفــاظ المتضادة.

ويقول السجستاني " أسروا الندامة"(1) أظهروها، ويقال كتموها

يعني كتمها العظماء من السفلة الذين أضلوهم ، و أسر من الأضداد"(r) وقد أشنار ابن الأبباري إلى عد هذه اللفظة من الأضداد فقــال "يكــون أسررت بمعني كتمت وهو الغالب علي الحــرف ، ويكـــون بمعنـي أظهرت"() وبالرجوع إلى معاجم اللغة كالصحاح و اللسان و القاموس (ع) وجدنا أن هؤلاء الأئمة قد نصوا علي أن هذه اللفظــة مــن الكلمــات المتضـادة ، أما الدكتور/أنيس فلم ير في هذه الكلمة تضـــادا ، ولــذلك ألك يقول "أليس من التكلــف و التعســـ أن تجعـلـ "الإســر ار" بمعنـي الإظهاركما يقول ابن الأنباري مفسر الآيتـين الكـريمتين "و أســروا

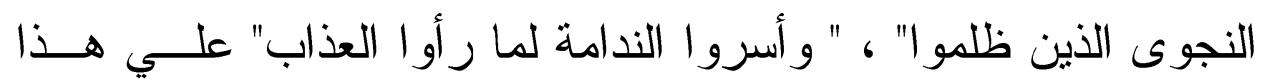
المعني أن الآيات الأخري التي وردث بالقرآن مشتملة علي هذه الكلمة

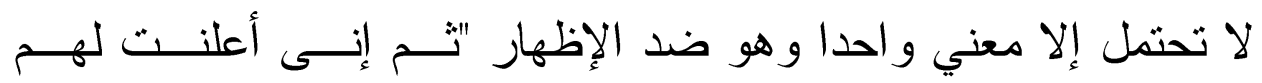

$$
\begin{aligned}
& \text { (1) من سورة سبأ آية (rr) }
\end{aligned}
$$

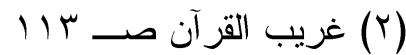

$$
\begin{aligned}
& \text { (ז) الصحاح و اللسان و القاموس (سرر) (برد) } \\
& \text { (أ) من سورة الأنبياء آية (r) }
\end{aligned}
$$




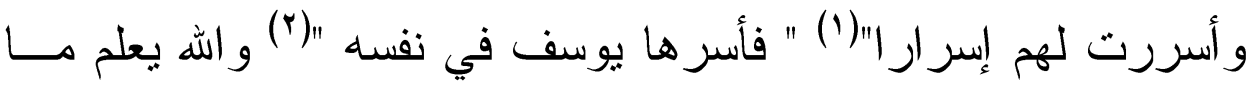

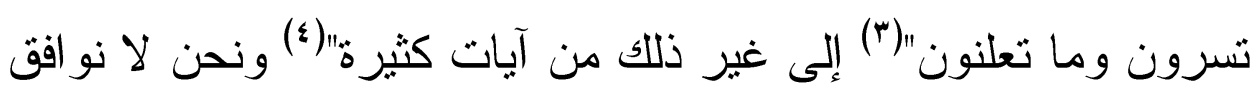

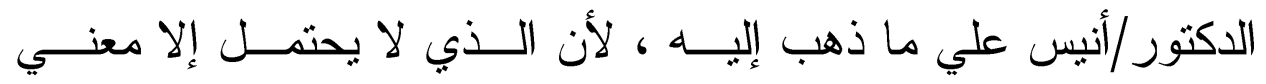

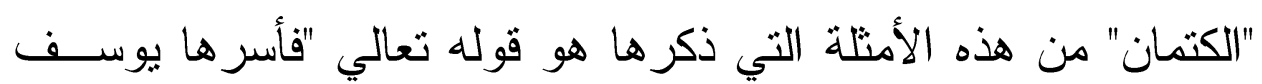
في نفسه" بقرينة قوله تعالي بعدها "ولم يبدها لهم" .

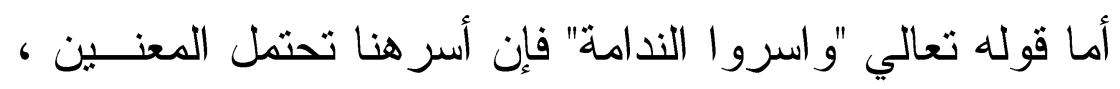

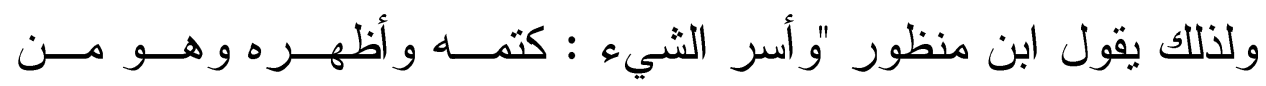

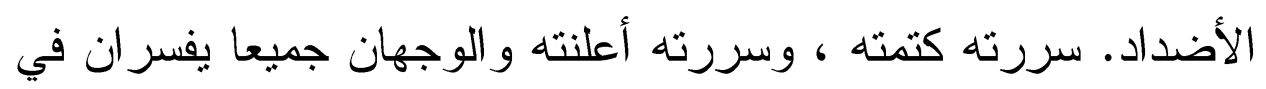

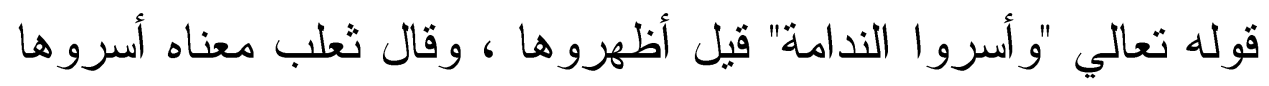

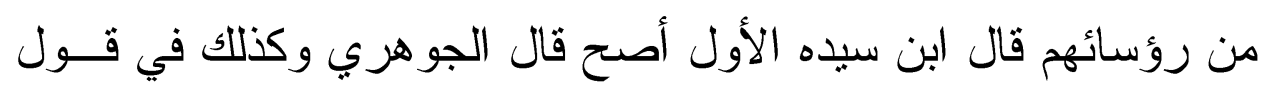
امرئ القيس :-

\section{لو يسرون مقتلي}

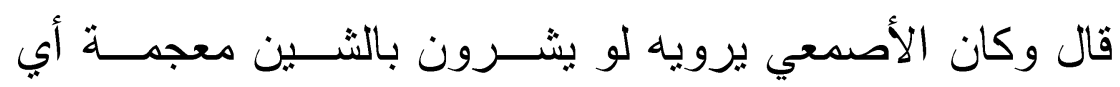

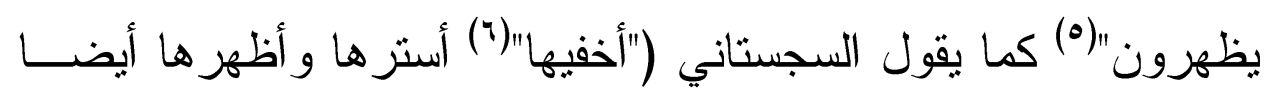

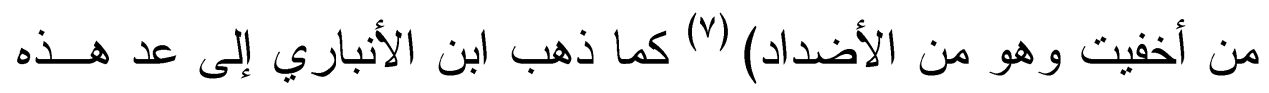

$$
\begin{aligned}
& \text { (1) من سورة نوح آية (9) (1) }
\end{aligned}
$$

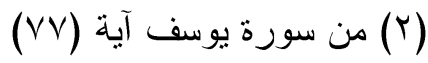

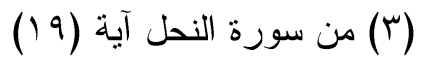

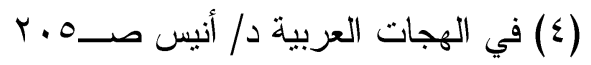

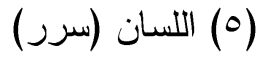

$$
\begin{aligned}
& \text { (7) من سورة طه آية(10) (10) } \\
& \text { غريب القز آن صــ (V) }
\end{aligned}
$$


اللفظة من الأضداد فقال "يقال : أخفيت الثيء إذا سترته ، وأخفيته إذا

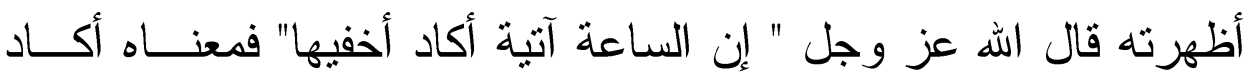

$$
\text { أستر ها..." (1) }
$$

كما اتفقت معاجم اللغة كالصحاح اللسان ، و أســاس البلاغــة

و القاموس علي عد هذه اللفظة من الأضداد. (r)

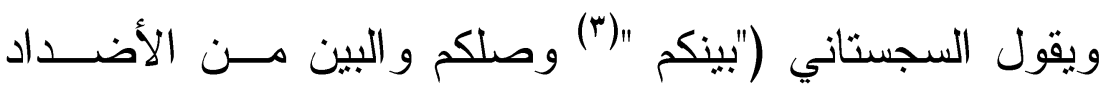

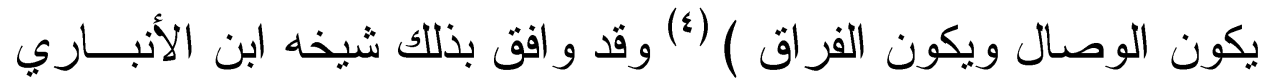
الذي يقول " يكون البين الفراق ، ويكون البين الوصال فإذا كان الفراق

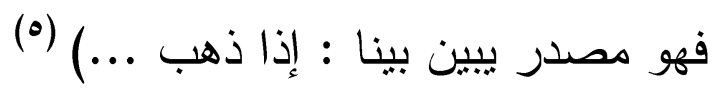

أما الدكتور /أنبس فلم بو افقهما علي عد هذه اللفظة من الأضـــداد

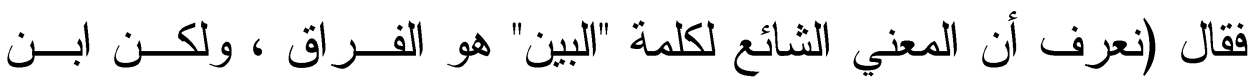

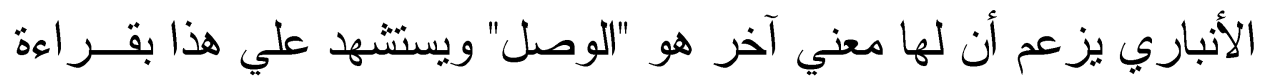
من قرأ" لقد تقطع بينكم" ولكن القر اءة المألوفة و المشهورة هي " لقد تقطع

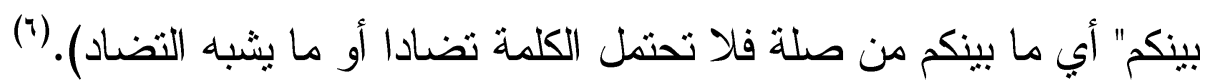

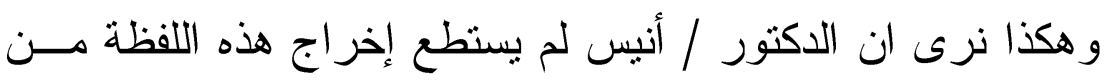

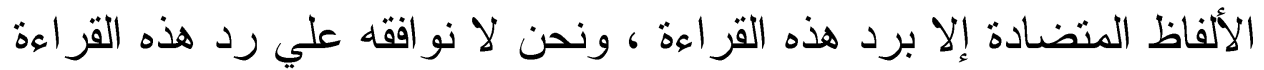

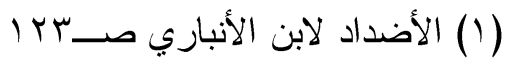

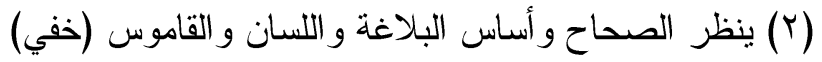

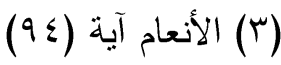

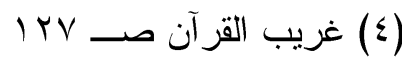

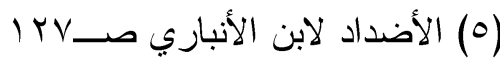

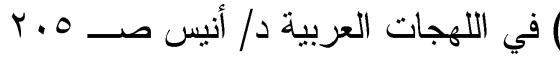


، ولا علي إخر اج هذه اللفظة دن دائرة الألفاظ المتضادة بدليل أن علمــاء

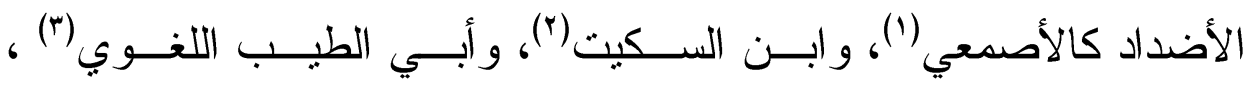

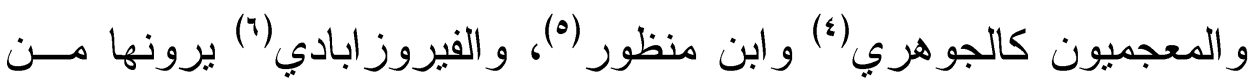

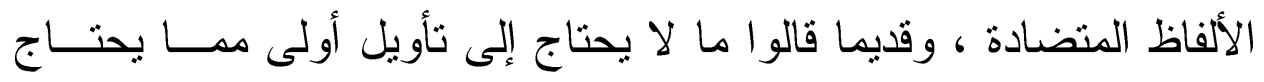

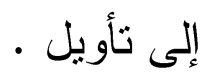
ويقول السجستاني ("تهجد"(V) اسهر ، وهجد : نم ) (^) وقد و افـق شيخه أبا بكر بن الأنباري في ذلك حيث يقول (يقال للنائم هاجد ، وللساهر

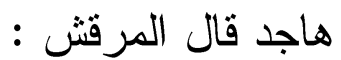

\section{سري ليلا خيال من سليمي ... فأرقني و أصحابي هجود}

وفال الله عز وجل " ومن الليل فتهجد به نافلة للك " فمعناه فاســـر به....) (9) أما الاكتور/أنيس فقد فسر النضاد في هذه اللفظة علي أنه مــن

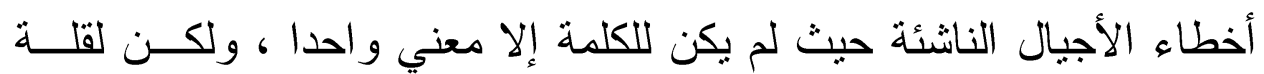
شيو عها فهمت في بيئة من البيئات علي معني آخر ثم نما هذا الفهـم وذاع في الجيل الناشيء ، ثم أصبح معنرفا به فـي اللغـــة النموذجيـــة الأدبيـــة

$$
\begin{aligned}
& \text { (1) (1) الأضداد للأصمعي صـ (1) }
\end{aligned}
$$

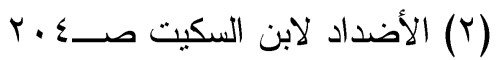

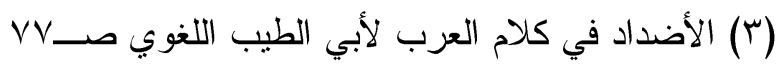

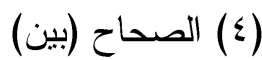

$$
\begin{aligned}
& \text { (0) اللسان (بين) (1) (الصناحن) }
\end{aligned}
$$

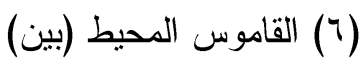

$$
\begin{aligned}
& \text { (V) في القرآن "فتهجد " سورة الإنسر اء آية (V) (V) }
\end{aligned}
$$

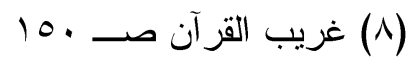

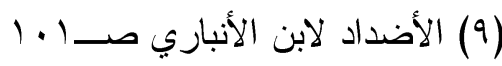


فاستعمل القرآن هذه الكلمة بمعني ، و استعملها المــرقش بمعنـي مضـــاد للمعني الأصلي ، وقد تم منل هذا التطور في عصور الجاهلية قبــل نشـــأة اللغة النموذجية و ازدهار ها "(') وأما الدكتور رمضان عبد التواب فإنه ممن يرون أن هذه اللفظة من الكلمات المتضادة أيضا إلا أنه فسر التضاد فيها ، وفيما كان علي شاكلتها بأنها اكتسبته عن طريق الســلب والإز الـــة الــذي اكتسبته بعض الأفعال التي جاءت علي صبغة "تفعل" مثل تحرج ، وتهجــــ بمعني تجنب الحرج و الهجود أي النوم، كما بقيت أفعال في العربية تحمـلـل المعني الأصلي إلى جانب هذا المعني الجديد ، ولما كان هــذان المعنيــان متضـادين تضاد الإيجاب و السلب أصــبحت تلــــ الأفعــال مــن كلمــات

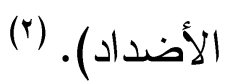

ويقول السجستاني أيضـا ("قروء"(") جمع قرء ، و القرء عند أهـلـل الحجاز الطهر ، و عند أهل العر اق الحيض ، وكل قد اصــاب لأن القــرء خروج من شيء إلى شيء فخرجت من الطهر إلى الحيض ودن الحـيض إلى الطهر هذا قول أبي عبيدة ، وقال غيره القرء : الوقت يقال رجع فلان لقرئه ، ولقارئه أيضا أي لوقته الذذي كان برجع فيه ، فالحيض يأني لوقت و الطهر يأني لوقت ... وقال ابن السكيت القرء : الطهر و الحيض وهو دن الأضداد) (\&) وقد وافق استاذه ابن الأنباري في عد هذه اللفظة من الأضداد حيث يقول ابن الأنباري (يقال " القرء للطهر وهو مــذهب أهــل الحجــاز و القرء للحيض وهو مذهب أهل العراق ... ويقال القرء هو الوقت الـذـي

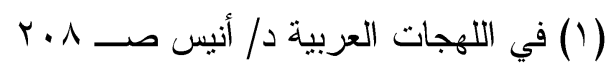

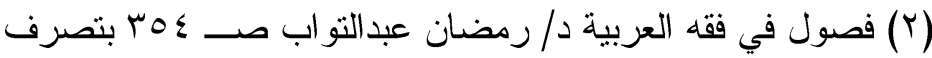

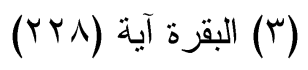

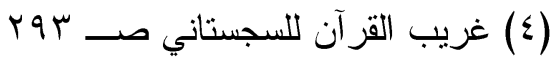


يحوز أن يكون فيه حيض ، ويجوز أن يكون فيه طهر ...) (') نتبين مهــا جاء عند كل من السجستاني و ابن الأنباري في كلمة "القرء" أن سبب نشوء التضاد في هذه الكلمة يرجع إلى الإبهام في المعنـي الأصــلـي و عمومـــه

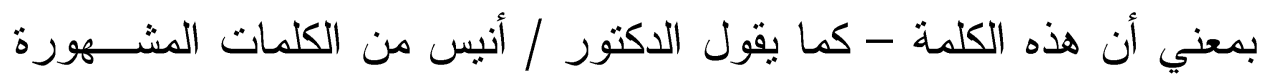
التي كان لها معني عام ثم تخصص في بيئتين مختلفتنين فاتخذ فــي البيئــة الأولي معني خاصـا ، وفي البيئة الثانية معني مضادا لذلك المعنــي الــذي شاع عند البيئة الأولي ... فيظهر أن المعني العام للكلمة هو الوقت - كما جاء كل من السجستاني وابن الأنباري و الاكتور/ أنيس ثم تخصــص فـي البيئتين علي معنيين مختلفين ومن هذا المعني العام اشتق القرء بمعني وقت المرض فيقل للمسافر ذهبت عنه "قر أة الحجاز أو قرئه" أي تبين أنه خــال من مرض الحجاز ، وقد قدروا هذه المدة بنحو خمسة عشر يوما) (r)

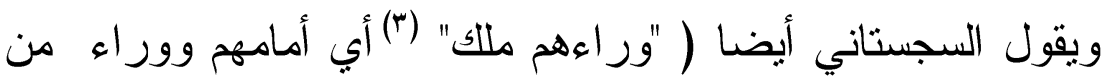

الأضداد يكون بمعني خلف وبمعني أمام) (\&) وقد و افق شيخه ابن الأنباري ،

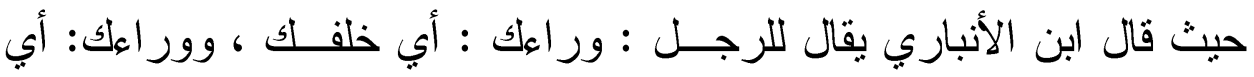
أمامك قال الله عز وجل "sن ور ائهم جهنم"(ه) فمعناه من أمامهر ، وقال تعالي " وكان ور اءهم ملك يأخذ كل سفينة غصبا" فمعناه ، وكان أماههم..)(") كمــا نص الكثير من علماء اللغة علي أن هذه اللفظة مــن الكلمــات المتضــادة

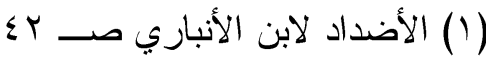

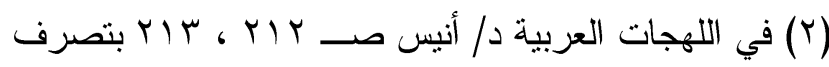

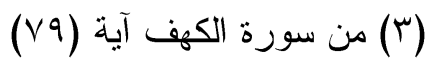
( ) غريب القرآن صـ (0) من سورة الجاثية آية (· (1) (1)

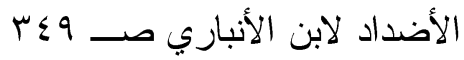


كالجوهري(') ، و ابن منظور ، و الفيروز ابادي ولعل منشأ التضاد فـي هــذه الكلمة برجع إلى اختلاف اللهجات العربية بمعني أن قبيلة ما استعملت هــذه الكلمة بمعني خلف قبل الإسلام ثم جاءت قبيلة أخرى فاستعملتها بمعني مقابل للمعني الأول دون علم منها باستعمال القبيلة الأولي لها في عكس هذا المعني فنشأ التضاد في هذه الكلمة. كما يقول السجستاني ("يظنون أنهم أنهم ملاقو اربهم"(؟) أب يوقنون ويظنون -أيضا- يشكون ، و الظن من الأضداد ) () وقد و افق أيضا شيخه ابن الأنباري الذي يقول الظن يقع علي معان أربعة :-

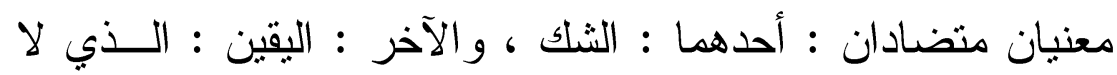
شك فيه فأما معني الثكك فأكثر من أن تحصى شو اهده ، و أما معني اليقـين فمنه قول الله عز وجل " وأنا ظننا أن لن نعجز الله في الأرض ولن نعجزه

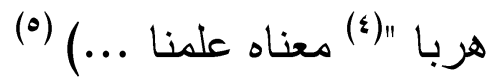
كما جاء عن أئمة اللغة ما يو افقه ففي الصحاح ( الظن معروف ، وقد يوضع موضع العلم قال دريد بن الصمة : فقلت لهم ظنوا بألفي مدجج .... سراتهم في الفارسي المسرد أي استنقنو ا ، و إنما يخوف عدوه باليقين لا بالثك ) (†) ومثلة جاء

في كل من اللسان و القاموس.

(1) ينظر الصحاح و اللسان والقاموس (ورى) (1) (1) (1) (1) (1)

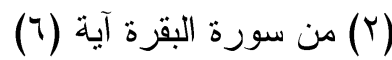

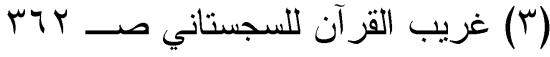

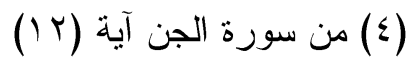

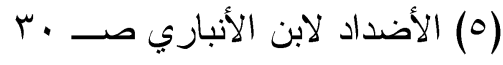

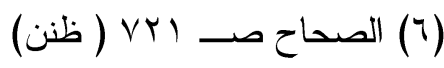

$$
\begin{aligned}
& \text { (V) ينظر اللسان و القاموس ( ظنن) }
\end{aligned}
$$


و علي كل حال فإنه - و الله أعلم - من الممكن أن نفسر التضاد في

هذه الكلمة بما فسرناه في الكلمة السابقة ، وذلك برجوعـة إلـى اخـــناف

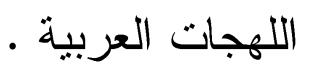

1- إذن نستتتج مما سبق أن هناك كلمات عدها السجستاني من المنضــاد وما هي دن المتضاد ، كما في كلمة "المقوين" وان هنالك كلمات تحامل عليه فيها الدكتور/أنيس منل كلمة"البين" ولم يكن له الحق في ذلك . r-كما نستتتج أيضا أن السجستاني قد عالج التضاد في عشرة مو اضع أي أن شو اهد التضاد في كتاب غريب القرآن للسجستاني قد بلغت عشــر كلمات تثريبا. r-كما أنه صرح في كل دن هذه المواضع بلفظة الأضداد علي عكس ما فعل في كل من المنز ادف و المشترك اللفظي اللذين لم بصر ح فــي أي هـي منهما بكلمة نز ادف أو مشترك لفظي . ع- أن السجستاني وإن كان هن هؤلاء العلماء المقرين بالتضناد فإنه كــان

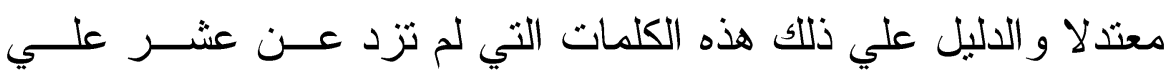
مستوي القرآن الكريم كله. 


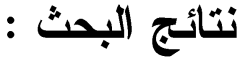

1- أن الصوت الأضعف فى الإدغام ينأثر بما هو أقوى منه دائما كما

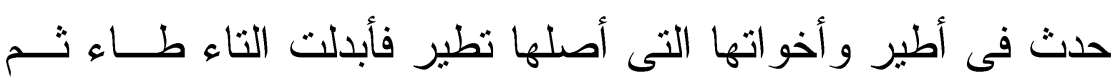

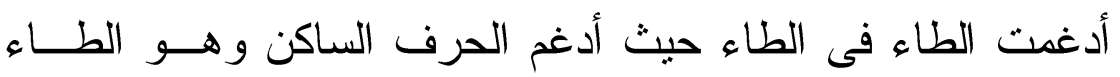

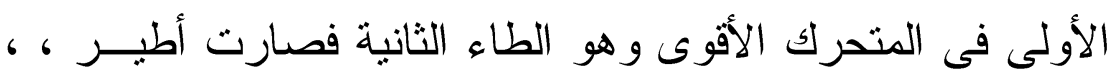

وكذلك الحال فى يهدى وغيرها .

Y- إن هناك صلة قويــة بــين المماتلـــة و الإدغـــام ، ولـــللك يقـول

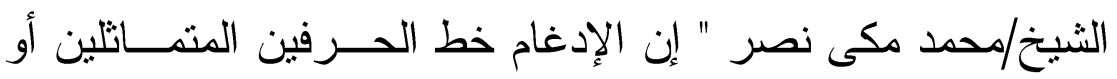

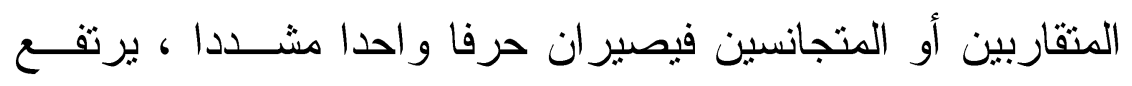

اللسان عند النطق بهما ارتفاعه و احدة "

r- إن كلا من المماتلة و المخالفة تهدف إلى تيسير النطــق ، وأن

المخالفة تبدأ حيث تتنهى المماثلة .

ع- أن النماذج النى أوردها السجستانى ، و التى صنفناها تحت باب

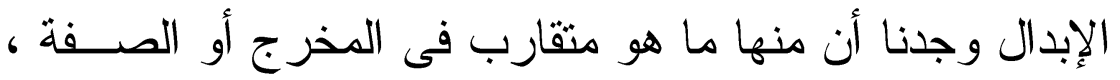

كما أن منها ما ليس بينهما علاقة صوتية فما انطبق عليه هــــا

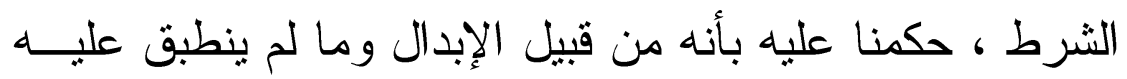

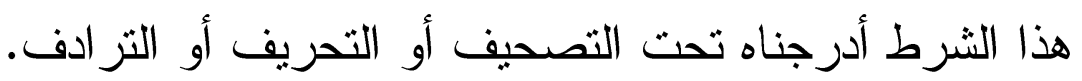

0- كما أن الإبدال كما يكون بين بعض الصوامت بعضها من بعض

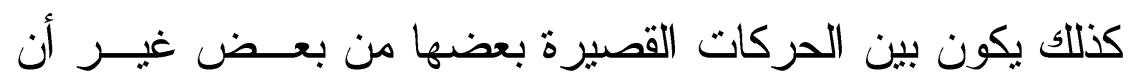

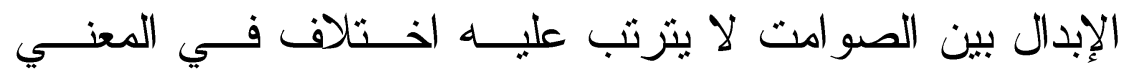


المعجمي بعكس الإبدال بين الصوامت بعضها من بعـض فقـــ يتزتب علي إبدال الصو امت بعضها من بعض وهـــي الحركـات القصيرة :"القتحة والكسرة و الضمة" اختلاف في المعني المعجمي للكلمة،وقد لا يترنب عليه اختلاف في المعني المعجمي. ؟- كما أن الهززة أثقل الحروف في النطق وذلك لبعــــ مخرجهــا فهي تحتاج إلى جهد عضلي كبير حين النطق بها وهي مخفقـــه ، لذا لجأت القبائل الحجازية إلى تخفيفها أما القبائل البدوية فقد لجأث إلى تحقيقها. V- أن التطور الدلالي للألفاظ قد وقع بالفعل فــي اللغـــة العربيــة

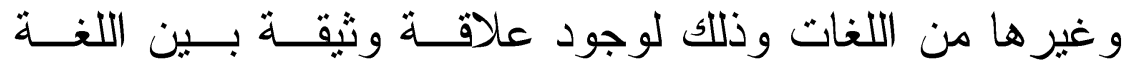

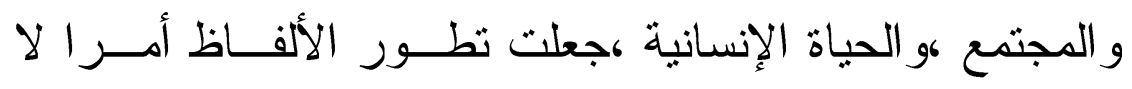
مناص منه ، وذللك لأن اللغة في ذلك شأنها شأن الكائن الحــي كما قرر ذلك الدرس اللغوي الحديث.

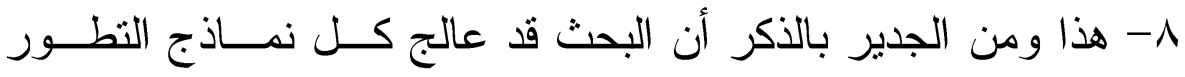

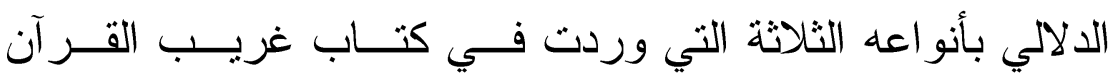
للسجستاني. 9- كما أنه قد تبين من خلال معالجات البحث لنمــاذج هــذا التطــور

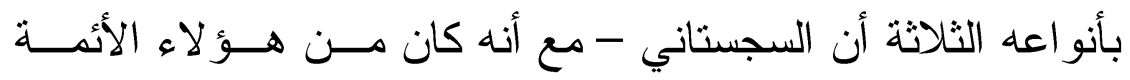

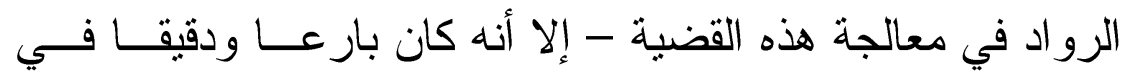
معالجاته لهذا الأمر ، وقد ظهر هذا بجلاء ووضوح مــن خــلال 
الدقارنات الكثثرة التي عقدناها بينه وبين كثثر من أئمة اللغة الذين أنو ا بعده من معجميين و غير هم.

• 1-كما أن السجتاني و إن كان من هؤلاء الأئمة الرو اد الذين يذهبون

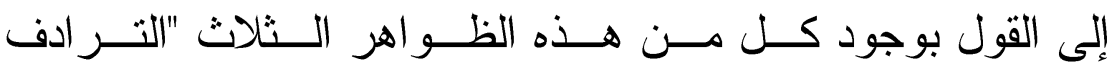

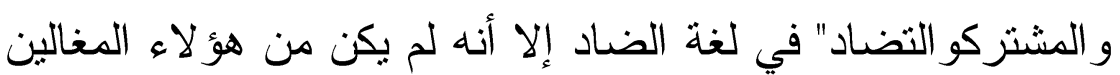
بل كان معتدلا ، كما قررنا ذلك في موضعه من البحث.

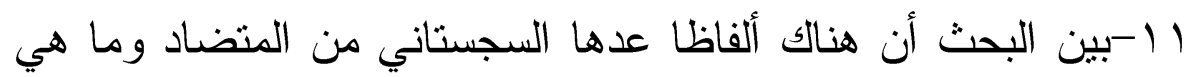

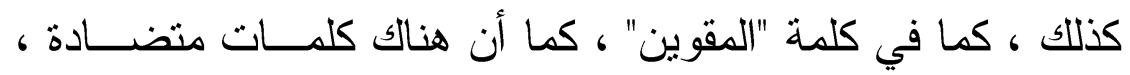

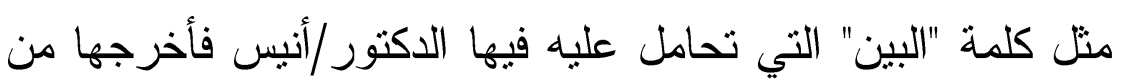
دائرة المتضاد ، وقد خانه التوفيق ذلك.

rأ-أن شوهد الاشتقاق الدلالي الجزئي بصورنيه كانت كثيرة إذا قيست

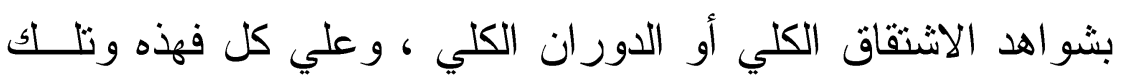

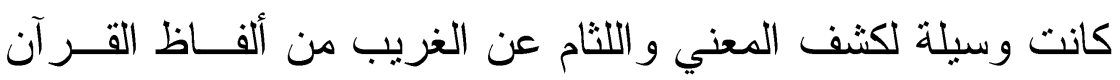
الكريم في كتاب غريب القران للسجستاني. 


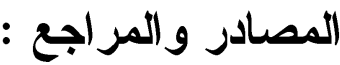

الإبدال لأبي الطيب اللغوي / تحقيق عــز الــدين التـــوخي / دمثــق

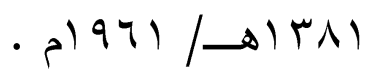

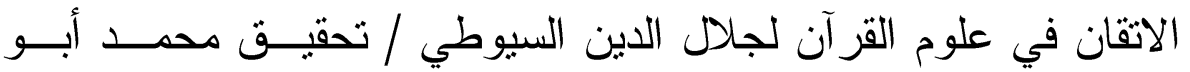

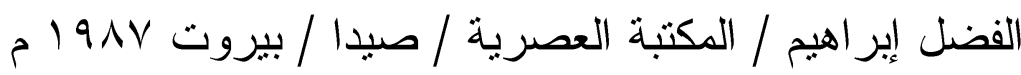
أساس البلاغة للزمخشري / تحقيق محمد باسل عيــون الســود / دار

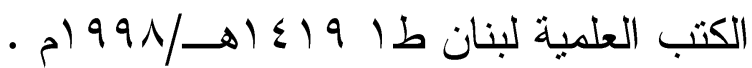

الأشباه و النظائر للثعالبي / تحقيق محمد المصــري / عــالم الكتــب .

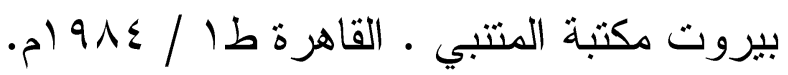
الاشتقاق - الأستاذ /عبداله أمين / القاهرة 907 (م. أثنتات مجتمعات في اللغة و الأدب / دار المعارف / طه وفيات الأعيان و أنباء أبناء الزمان لابن خلكان / تحقيق د/ إحسان عباس - دار صادر بيروت .

أصوات اللغة العربية / د. محمد حسن جبل / الطبعة الثالثة . الأضداد لابن الأنباري / تحقيق الثربيني شريدة / دار الحديث القاهرة

$$
\text { r. . 9/- } 1 \leq r \text {. }
$$

الأعلام / خير الدين الزركلي / دار العلم للملايــين / بيـروت طه /

$$
\text { م) } 91 \text {. }
$$

البحث اللغوي عند العرب مع دراسة لقضية التأثنر والتــاثز /د.أحمـــ

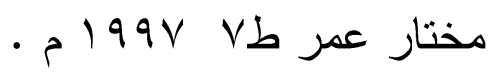
البحر المحيط لأبي حيان / در اسة وتحقيق /عادل أحمــد عبــدالموجود و آخرين / دار الكتب العلمية / بيروت ـ لبنان • 
بحوث ومقالات في اللغة د/ رمضـان عبــدالتواب /مكتبــة الخــانجي/ ط

بغية الوعاة في طبقات اللغويين و النحاة / لجلال الدين عبدالرحمن ابن أبي بكر السيوطي / تحقيق محمد أبو الفضل إبر اهيم / مطبعة عيسـي البابي الحلبي / مصر ط | ع 197 م.

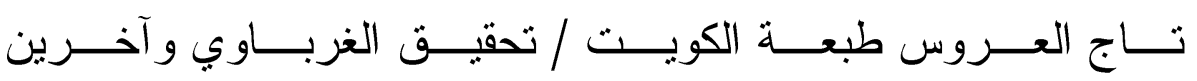
م) $980 / \rightarrow 1190$

تاريخ آداب العرب للر افعي / مصطفي صادق الرفاعي / دار الكتــاب

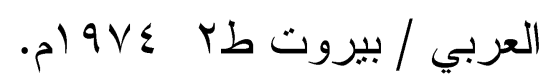

تحفة الأريب بما في القرآن من الغريب لأبي حيان محمد بن يوســف الأندلسي / تحقيق د/ سمبر طه المجذوب / المكتب الإسلامى · بيروت - $1911 \mathrm{r}$

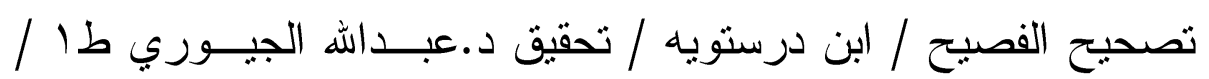

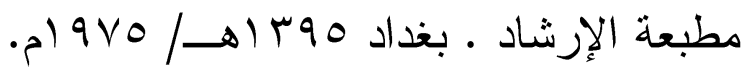

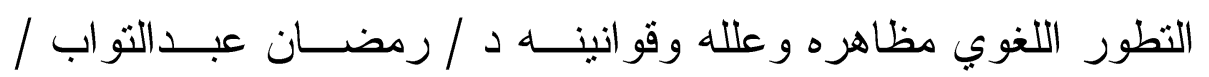
الطبعة الثالثة / مكثبة الخانجي ، بالقاهرة. تقسير القاسي " محاسن التأويل" محمد جمال القاسي / ضبط محمد عيون

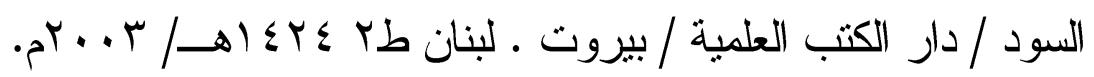

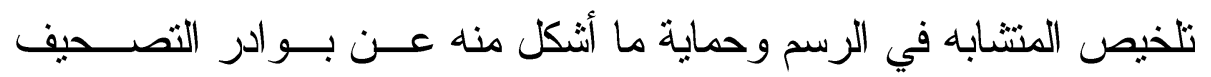
و الو هم للبغدادي / تحقيق سكينة الثهابي/ دار طلاس/ دمشق طا 910 ام. تهذيب اللغة ـ الأزهري / تحقيـق عبدالســلام هـــارون و آخـرين / م) $9 \vee 0-$ - $197 \leq$ 
تهذيب اللغة للأزهري / تحقيق عبدالسـام محمــد هـــارون و آخــرين - $) 975$ الحجة في القراءات السبع • ابن خالويه / تحقيق د. عبدالعال سالم مكرم

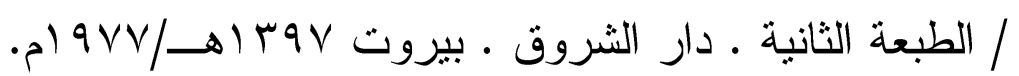
الخصائص / صنعة أبي الفتح عثمان بن جني / تحقيق محمــــ علـي النجار /دار الثئون الثقافية العامة / الطبعة الر ابعة ـ بغداد ـ99 ام ـ الار اسات اللغوية عند العرب إلى نهاية القرن الثالث / محمد حسين آل

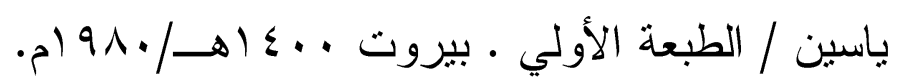
در اسات في فقه اللغة د/صبحي الصالح ـ دا العلم للملايين بيروت.

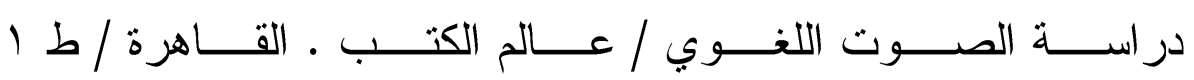
م) $991 /-8 \leqslant 11$

دلالة الألفاظ - د/أنيس / مكتبة الانجلو المصرية / القاهرة 9 أم. الذريعة إلى أهل تصـانيف أهل الثــيعة / أقــابزرك الطهر انــي / دار

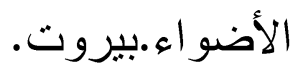

رواية اللغة / عبدالحمبد الثلقاني • دار المعارف مصر 9 ام. سر صناعة الإعراب لأبي الفتح عثان بن جني/ تحقيق أحمد فريد أحد

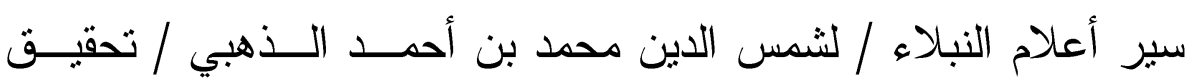

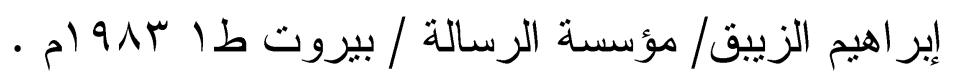
شرح المفصل لابن بعيش / عالم الكتب / بيروت/ مكتبة المتتبي القاهرة

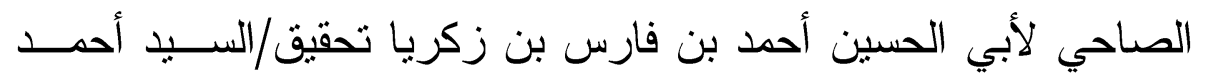
صقر / مطبعة الحلبي • القاهرة. 


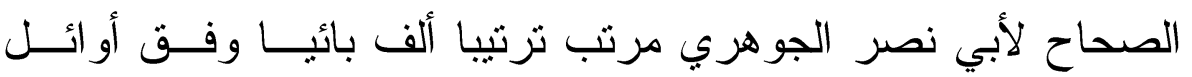
الحروف / دار الحديث القاهرة / مراجعة د/محمد محمد تامر وآخرين

$$
\left.\cdot{ }^{r} \cdot .9 /-ه\right) \text {. }
$$

الأصوات اللغوية د/إبر اهيم أنيس / الطبعــة الخامســة 9 / 9 مكتبــة الأنجلو المصرية الهول

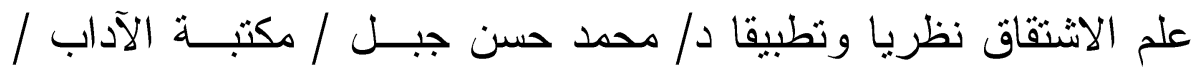

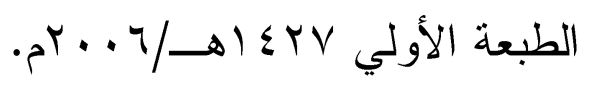
علم الأصوات د. كمال بشر / دار غريب للطباعة و النشر علم اللغة د. علي و افي / الطبعة التاسعة ؛ ـ. . بم العين للخليل بن أحمد تحقيق د/ مهدي المخزومي د/ إبر اهيم السامر ائي

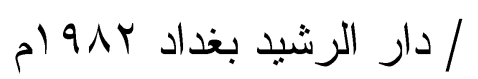

غريب القر آن علي حروف المعجم للسجسناني • در اسة وتحقيق / أحمد

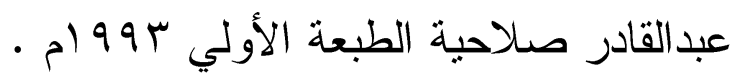
فصول في فقــه العربيــة /د.مضـــان عبـــالتواب / الطبحسـة الثالثــة

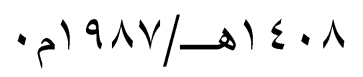
فقه اللغة د/ علي و افي / دار نهضة مصر / الفجالة القاهرة. فقه اللغة وخصائص العربية للأستاذ / محمد المبارك / الطبعة الثانية . الفهرست لابن النديم ، دار المعرفة / بيروت لبنان.

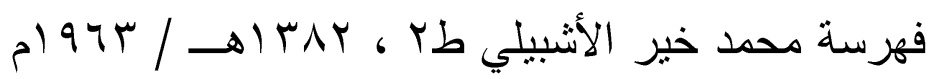
في اللهجات العربية د/ إبر اهيم أنيس / مكتبة الانجلو المصرية / الطبعة - التاسعة 990 (م 


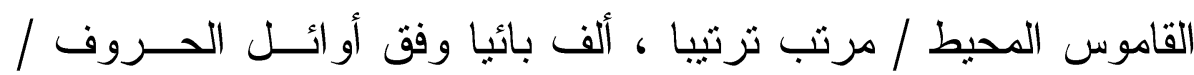
، تأليف مجد الدين محمد بن يعقوب / مر اجعة / أنس محمد الثــامي

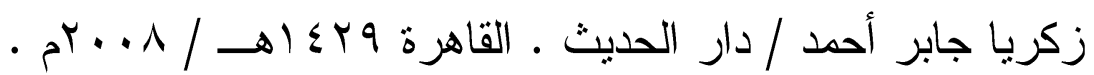
كتاب الغرر المنلثة و الدرر المبثنة للفيروز ابــادي / تحقبـق ودر اســة

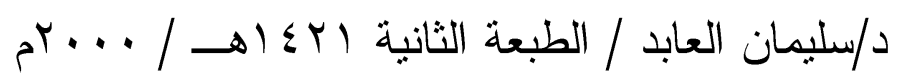

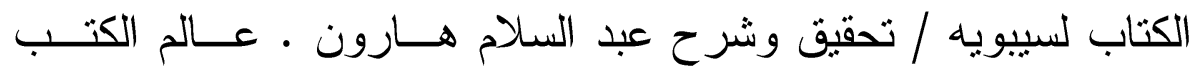
للطباعة و النشر و التوزيع / بيروت. الكتاب لسيبويه / شرح وتحقيق عبدالسلام هارون ، مكتبــة الخــانجي

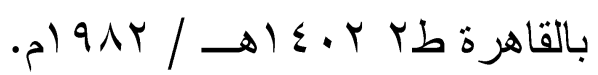
كثف الظنون عن أسامي الكتب والفنون - لحاجي خليفة ، مصــطفي ابن عبدالله الرومي / دار الفكر • بيروت ra19 ام • لسان العرب لابن منظور المصري / دار الكتب العلمية. بيروت لبنان

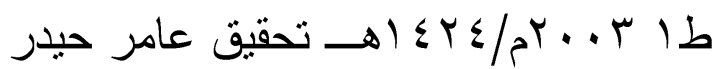

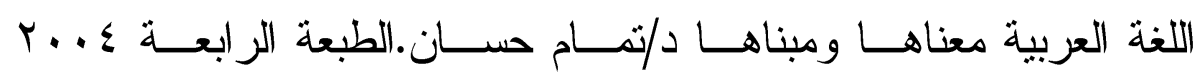
$\rightarrow \leq Y 0 / 2$

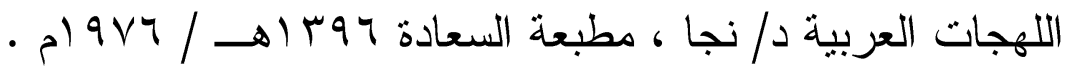
المؤتلف و المختلف في أسماء الرواة / لعبدالغني بن سعيد / مخطــوط IIVV محفوظ بمكتبة الأسد الوطنية / دمشق رقي

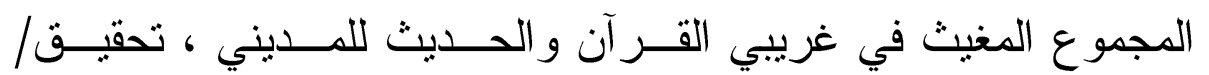

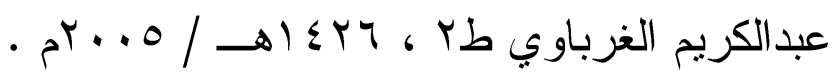
المحكم و المحيط الأعظم في اللغة لابن سيده تحقيق/د.عبدالحمبد هنداوي / منشور ات محمد علي بيضون / دار الكتب العلمية / بيروت لبنان. 
مدخل إلى تعريف الأضداد ناليف د/ حسين نصـــار /الطبعـــة الأولــي

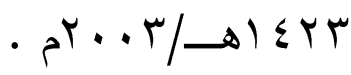
المزهر في علوم اللغة و أنو اعها للسيوطي / شرحه وضبطه / محمـــ أحمد جاد المولي بك و آخرين / الطبعة الثالثة / مكتبة دار التراث. المصباح المنير في غريب الثرح الكبير للر افعي / تاليف العلامة أحمد ابن محمد الفيومي تحقيق د/ عبدالعظيم الثناوي.

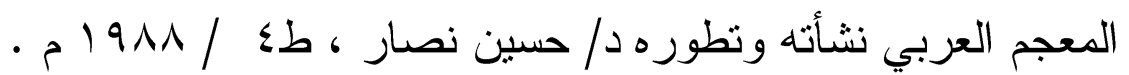

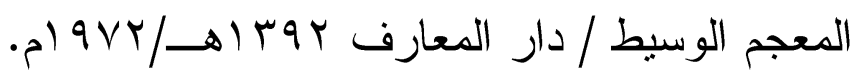
معجم المؤلفين / عمر رضا كحالة / دار إحياء التراث العربي.

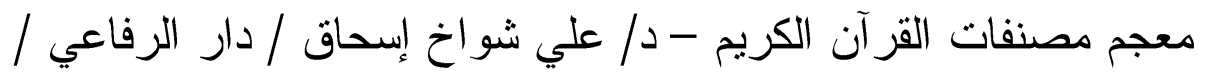

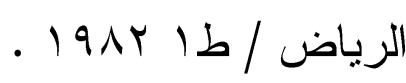
مفاتيح الغيب / دار الفكر / الطبعة الأولي 1 +ـ اهـ/919 (م.

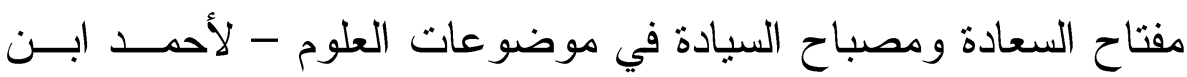
مصطفي الشهير بطاش كبرى زاده / دار الكتب العلمية . المقتبس من اللهجات العربية والقر آنية د/ سالم محيسن / الطبعة الأولي - ) $9 \vee \wedge / \rightarrow 1 \% 9$ من أسرار اللغة / مكتبة الأنجلو المصرية طل الن 1990 م •

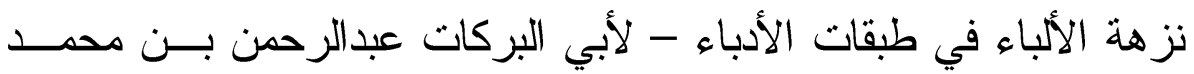
الأنباري تحقيق د/ إير اهيم السامرائي ـ مطبحة المعارف ـ بغداد 909 ام. النشر في القراءات العشر لابن الجزري / تصحيح ومر اجعة علي محمد الضائع / المكتبة التجارية الكبري / مطبعة مصطفي محمد بمصر . 


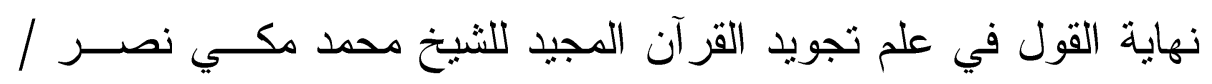

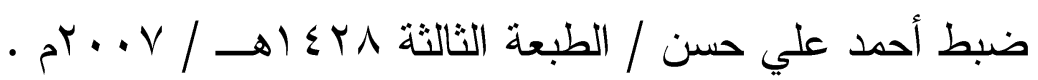

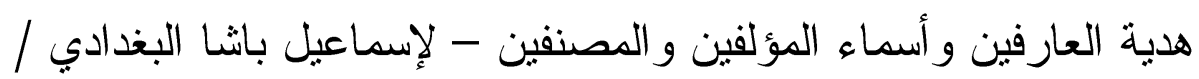
دار الفكر بيروت r 919 ام . الوسيط

وفيات الأعيان لابن خلكان / تحقيق د/إحسان عبـاس / دار صــادر •

$$
\text { بيزوت }
$$


فهـارس الكتهـاب

\begin{tabular}{|c|c|}
\hline \multirow[t]{2}{*}{ الصفحة } & 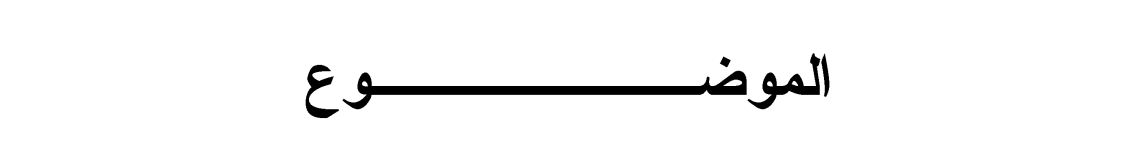 \\
\hline & المقدمة : \\
\hline & تمهيد :السجستانى وكتابة "غريب القرآن" ويشمل الأمور الأتية: \\
\hline & اسمه ونسبه. \\
\hline & نشأته وحياته. \\
\hline & شيوخه ومعلموه \\
\hline & 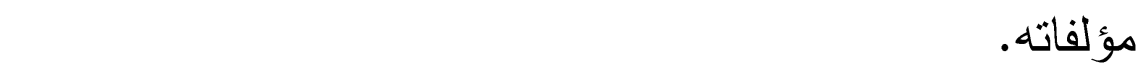 \\
\hline & 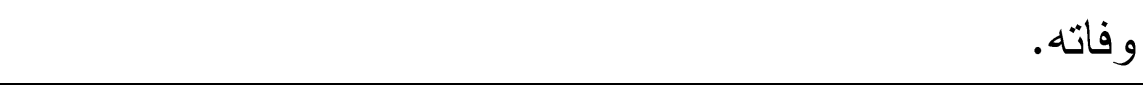 \\
\hline & اختلاف تسمية الكتاب. \\
\hline & وقفة مع المدلول اللغوى و الاصطلاحى لكلمة " غريب ". \\
\hline & المقصود بغريب القرآن. \\
\hline & منهج المؤلف فى عرض مادة هذا الكتاب. \\
\hline & الباب الأول : الدرس الصوتى فى " غريب القرآن " للسجستانى \\
\hline & الفصل الأول : الإدغام. \\
\hline & الفصل الثانى : المخالفة الصوتية. \\
\hline & الفصل الثالث : الإبدال ويتكون من مبحثين . \\
\hline & المبحث الأول : الإبدال بين الصوامت بعضها من بعض. \\
\hline & المبحث الثانى : الإبدال بين الصوامت القصبرة بعضها من بعض. \\
\hline
\end{tabular}




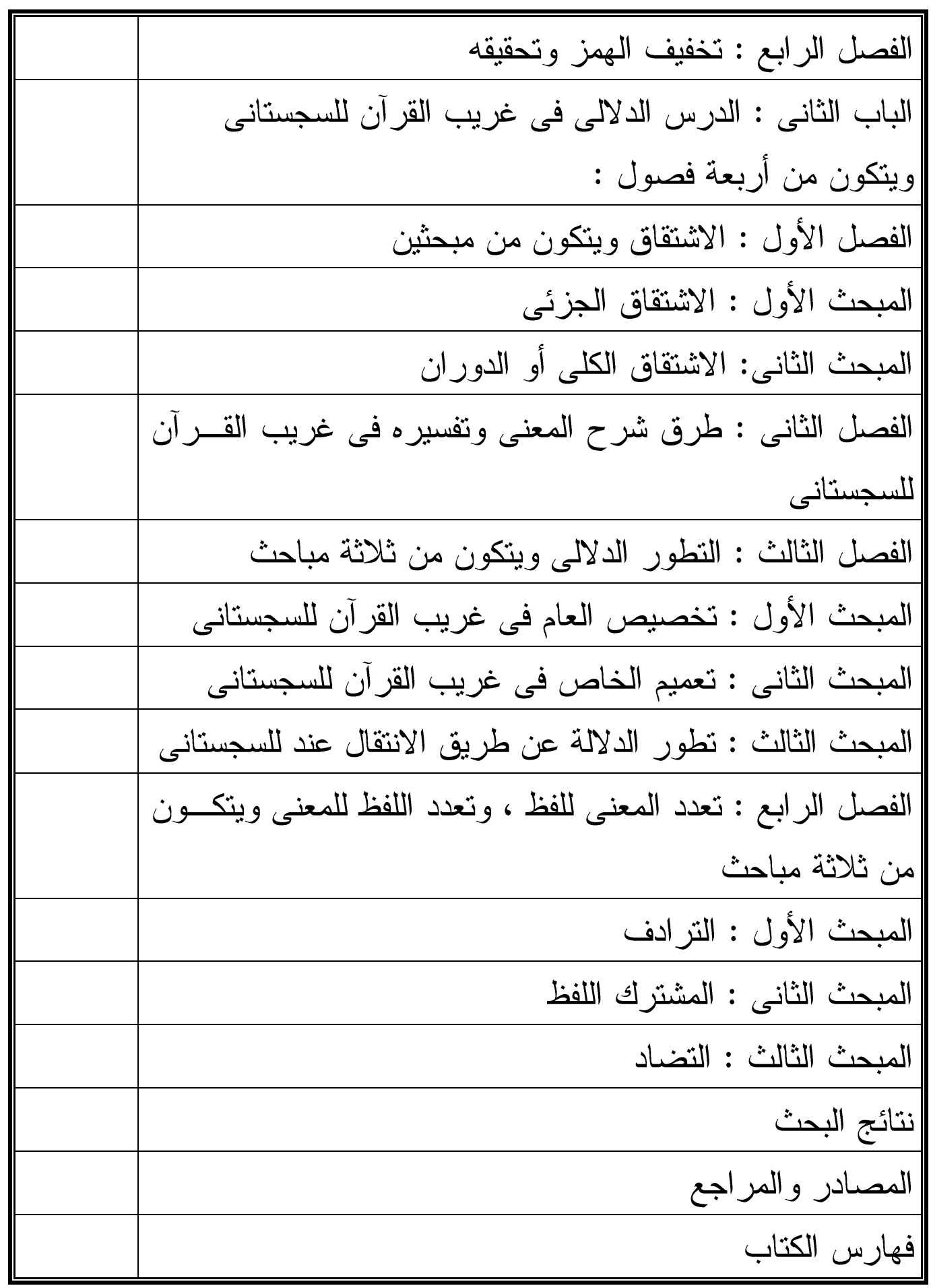

